\title{
NARRATIVE OBTRUSION IN THE HEBREW BIBLE
}

\author{
By \\ Christopher T. Paris \\ Dissertation \\ Submitted to the Faculty of the \\ Graduate School of Vanderbilt University \\ in partial fulfillment of the requirements \\ for the degree of \\ DOCTOR OF PHILOSOPHY
}

in

Religion

May, 2012

Nashville, TN

Approved:

Professor Jack M. Sasson

Professor Douglas A. Knight

Professor Annalisa Azzoni

Professor Alice Hunt

Professor Herbert Marbury

Professor David Wasserstein 
In memory of my grandfather William Kyle who first introduced me to the concept of omniscience 


\section{ACKNOWLEDGMENTS}

Many individuals have contributed to the successful completion of this project through their academic expertise, their challenges to improve my work, and their kind words. I would like to thank the members of my dissertation committee for the many ways they have helped me to grow as a scholar: Professor Douglas A. Knight, Professor Annalisa Azzoni, Professor Alice Hunt, Professor Herbert Marbury, and Professor David Wasserstein. In particular, I owe a great deal of gratitude to my advisor Professor Jack M. Sasson for encouraging my pursuit of this topic and pushing me to expand it in new and fruitful ways.

I express much thanks to my parents Ben and Janey Paris. When my dad first read me the Samson story, little did we know that it would one day become the foundation for my dissertation. I also greatly appreciate my mother-in-law Elaine Davis for her encouragement. My friends at the GDR, CFT, the Writing Studio, GPC, and WKU have all been essential to my journey. Most of all, I am thankful to have walked this path with my wonderful wife Lydia who has never wavered in her support -even though the road has been long. And, of course, I cannot leave out my brilliant son Luke. When I began writing my dissertation, he was very young and referred to it as my "diss-ro-tation." He has brought joy and balance to the process by giving me breaks to play football and many other sports. I cherish the memories of my time as a graduate student at Vanderbilt, and the many people who made this journey possible. 


\section{TABLE OF CONTENTS}

ACKNOWLEDGMENTS iii

LIST OF FIGURES ................................................................................... vi

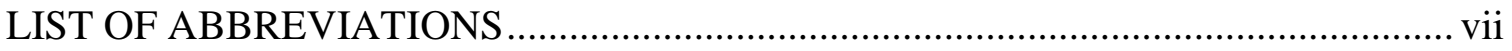

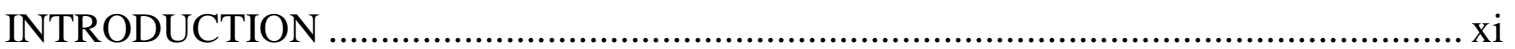

\section{Chapter}

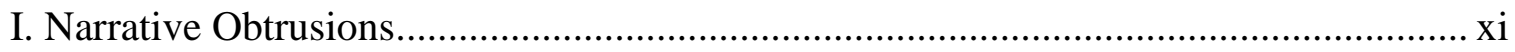

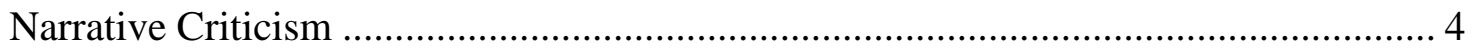

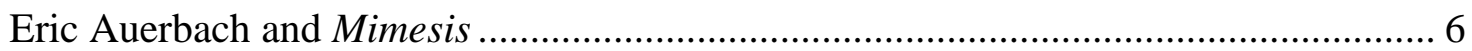

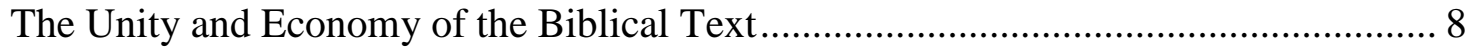

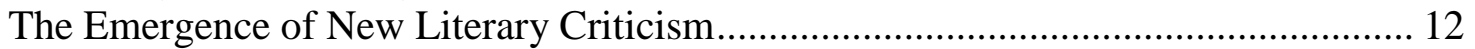

Narrative Criticism and Reader-Oriented Approaches ........................................... 15

The New Testament and Narrative Criticism ..................................................... 17

Robert Alter and The Art of Biblical Narrative ........................................................ 19

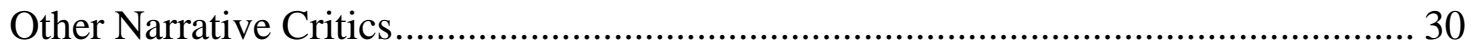

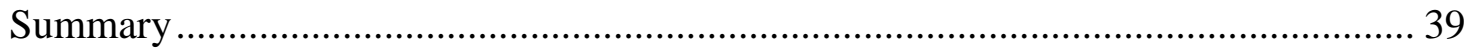

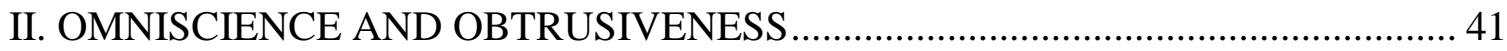

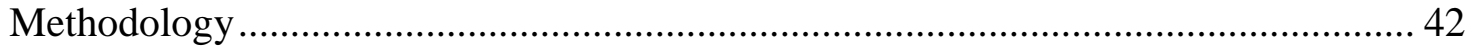

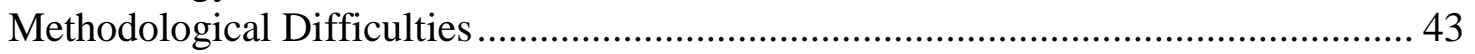

Obtrusiveness Begins with Omniscience............................................................... 48

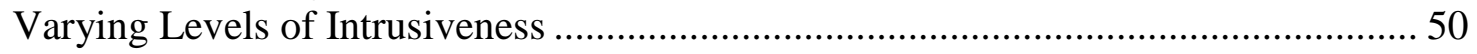

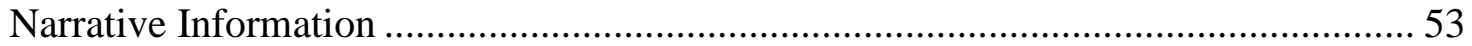

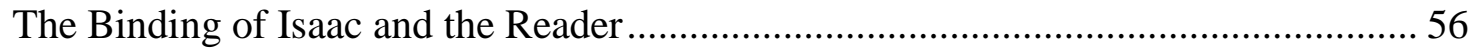

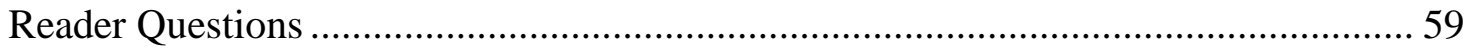

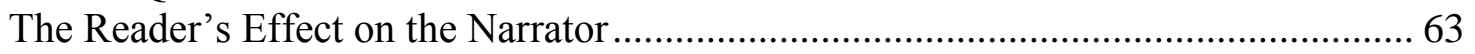

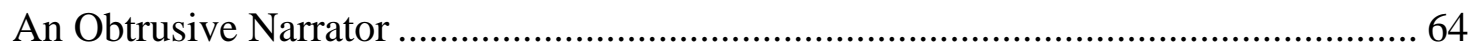

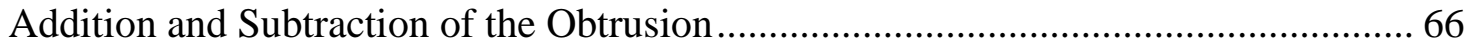

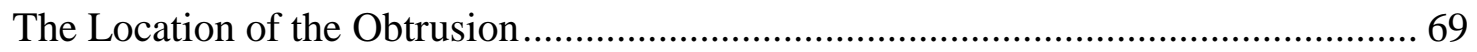

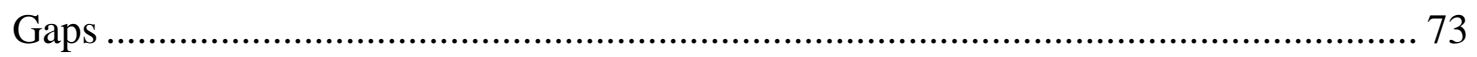

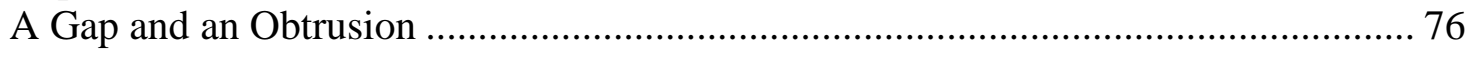

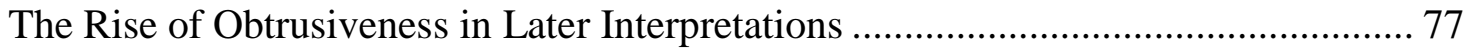

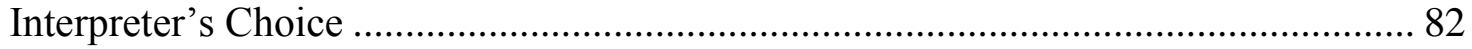


III. THE NARRATIVE OBTRUSION OF JUDGES 14:4 ........................................ 85

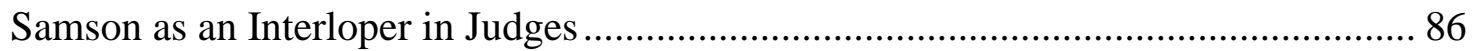

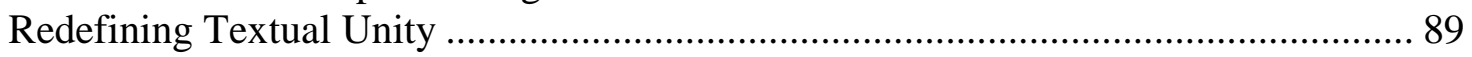

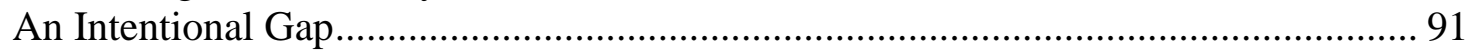

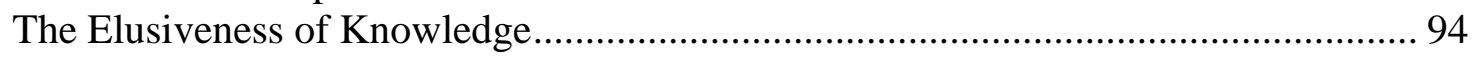

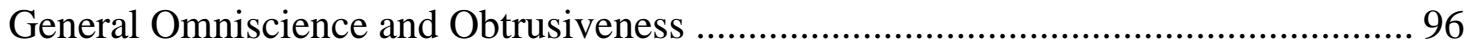

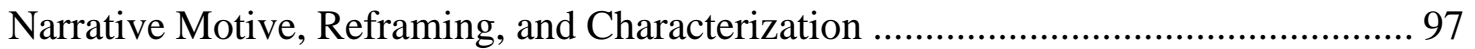

An Occasion or a Pretext? ................................................................................ 105

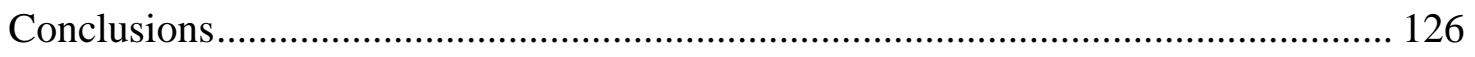

IV. READER RESPONSE, NARRATOR FORESIGHT AND FORECLOSURE ....... 128

Building a Framework .................................................................................... 130

Obtrusiveness in Joshua................................................................................... 133

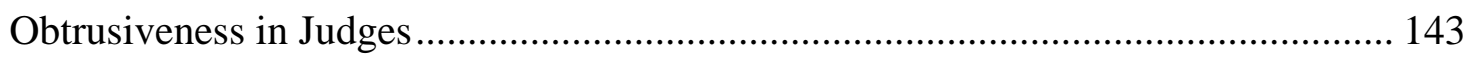

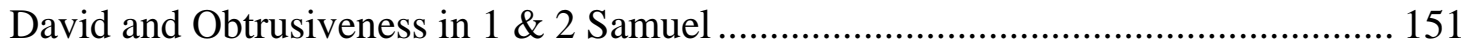

\section{SELECTED EXAMPLES OMNISCIENT AND OBTRUSIVENESS}

IN ANCIENT NEAR EASTER LITERATURE ............................................. 165

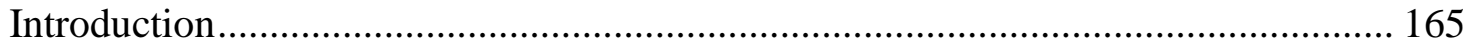

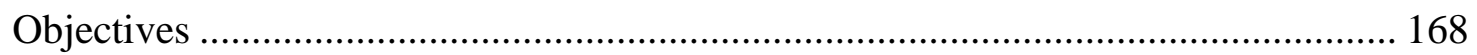

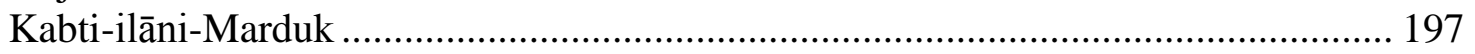

A Negative Obtrusion in The Poor Man of Nippur ........................................... 203

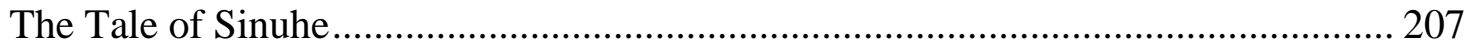

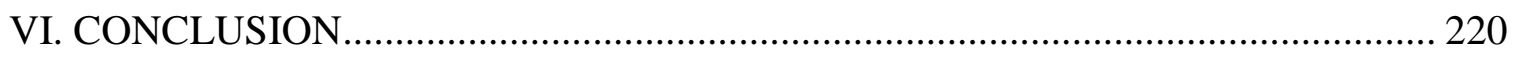

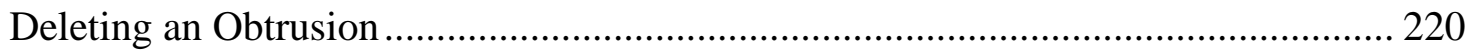

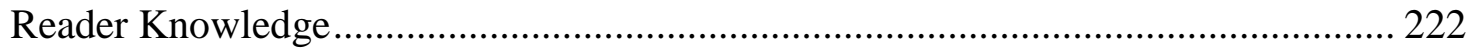

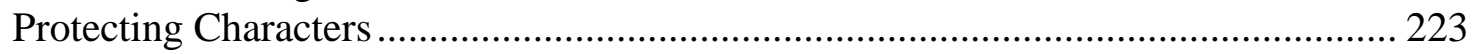

The Desire for Sharper Obtrusions .................................................................... 224

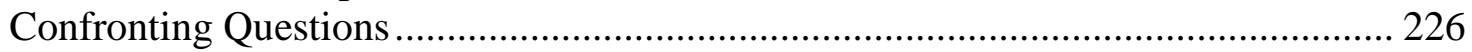

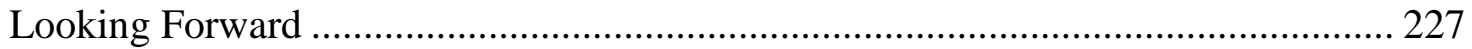

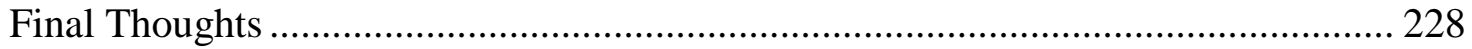

APPENDIX A: SELECTED OBTRUSIONS FROM THE HEBREW BIBLE ............ 230

APPENDIX B: SOME MORE OBTRUSIONS NOT COVERED IN THIS STUDY ... 234

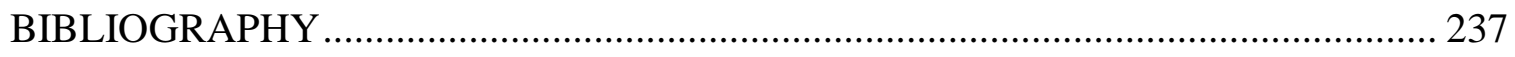




\section{LIST OF FIGURES}

Figure

Page

Figure 1. Ranges of Intrusiveness from Least Intrusive to Most Intrusive ...................... 52

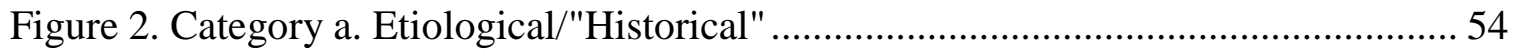

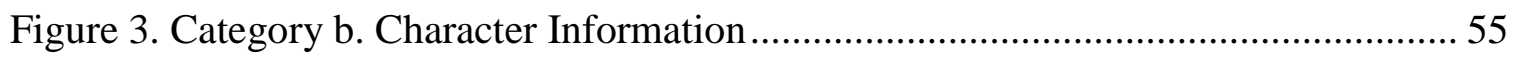

Figure 4. Category c. Information about the Divine ................................................ 56

Figure 5. Potential Obtrusions in Judg 9:23-24, 56-57 ........................................ 147 


\section{LIST OF ABBREVIATIONS}

AbrN

$A B D$

AEL

A.J.

AOAT

$A B D$

AGJU

ATAT

AzTh

BZAW

$B A$

BDB

BETL

Bib

BibInt

BJS

BLS

$B N$

BR

$\mathrm{CBC}$

Abr-Nahrain

Anchor Bible Dictionary. Edited by D.N. F. Freedman. 6 vols. New York, 1992

Ancient Egyptian Literature. M. Lichtheim. 3 vols. Berkley, 1971-1980.

Antiquitates judaicae

Alter Orient und Altes Testament

Anchor Bible Dictionary. Edited by D.N. F. Freedman. 6 vols. New York, 1992

Arbeiten zur Geschichte des antiken Judentums und des Urchistentums

Arbeiten zu Text und Sprache im Alten Testament

Arbeiten zur Theologie

Beihefte zur Zeitschrift für die alttestamentliche Wissenschaft

Biblical Archaeologist

Brown, F., S. R. Driver, and C. A. Briggs. A Hebrew and English Lexicon of the Old Testament. Oxford, 1907.

Bibliotheca ephemeridum theologicarum lovaniensium

Biblica

Biblical Interpretation

Brown Judaic Studies

Bible and Literature Series

Biblische Notizen

Biblical Research

Cambridge Bible Commentary 


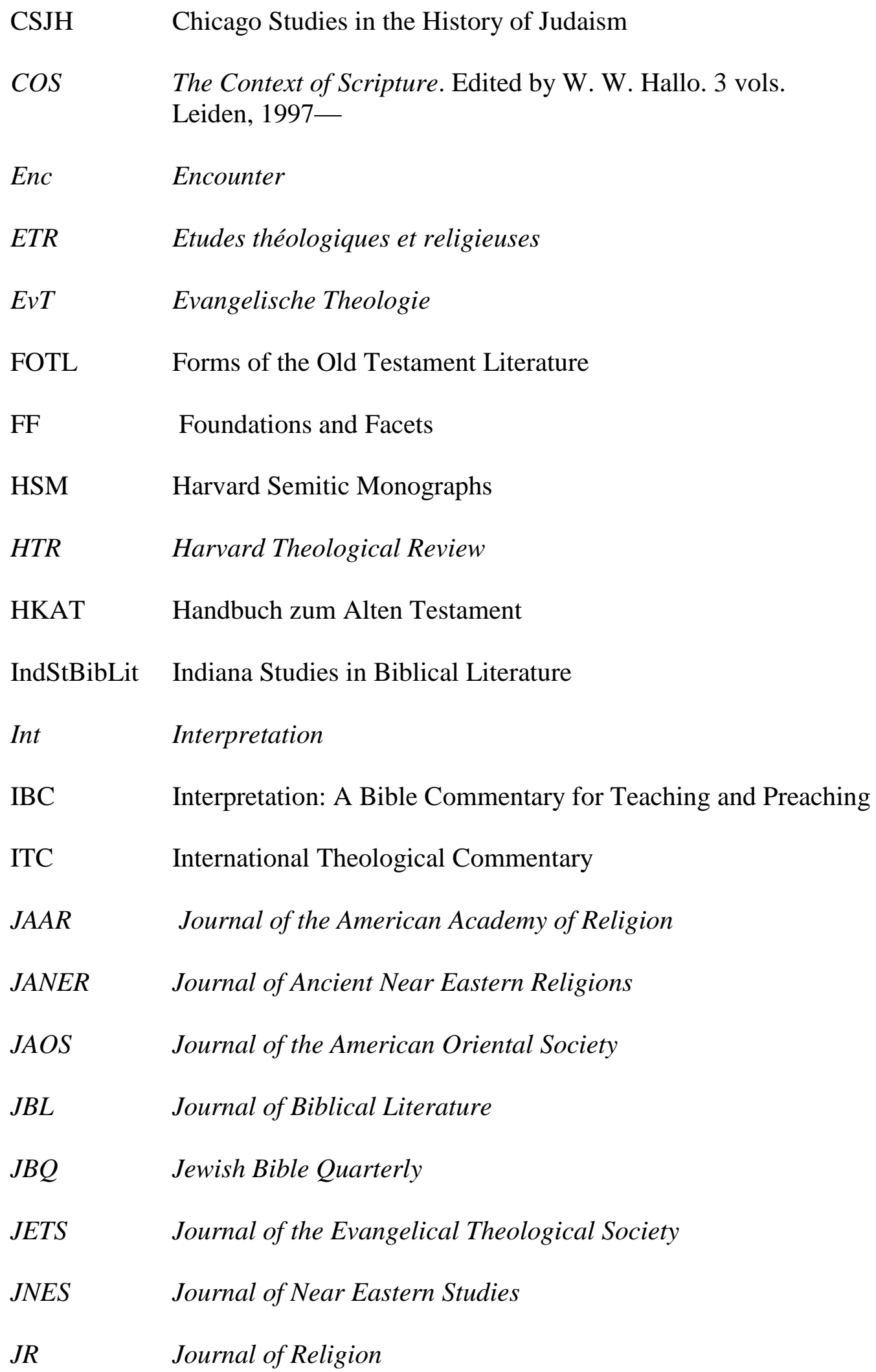

JSNTSup Journal for the Study of the New Testament: Supplement Series 


\begin{tabular}{|c|c|}
\hline JSOT & Journal for the Study of the Old Testament \\
\hline JSOTSup & Journal for the Study of the Old Testament: Supplement Series \\
\hline$J S J$ & $\begin{array}{l}\text { Journal for the Study of Judaism in the Persian, Hellenistic, and Roman } \\
\text { Periods }\end{array}$ \\
\hline LD & Lectio Divina \\
\hline$M Q R$ & Michigan Quarterly Review \\
\hline NCBC & New Cambridge Bible Commentary \\
\hline $\mathrm{NCB}$ & New Century Bible \\
\hline NIBCOT & New International Biblical Commentary on the Old Testament \\
\hline $\mathrm{OBO}$ & Orbis biblicus et orientalis \\
\hline OtSt & Oudtestamentische Studiën \\
\hline PIASH & $\begin{array}{l}\text { Proceedings of the Israel Academy of Sciences and } \\
\text { Humanities }\end{array}$ \\
\hline PRSt & Perspectives in Religious Studies \\
\hline Proof & Prooftexts \\
\hline RHPR & Revue d'historie et de philosophie orientale \\
\hline Scr & Scripture \\
\hline SBS & Stuttgarter Bibelstudien \\
\hline SBLRBS & Society of Biblical Literature Resources for Biblical Study \\
\hline SBLWAW & $\begin{array}{l}\text { Society of Biblical Literature Writings from the Ancient } \\
\text { World }\end{array}$ \\
\hline Sem & Semeia \\
\hline SemeiaSt & Semeia Studies \\
\hline SubBi & Subsidia Biblica \\
\hline TOTC & Tyndale Old Testament Commentaries \\
\hline
\end{tabular}




$\begin{array}{ll}\text { TynBul } & \text { Tyndale Bulletin } \\ \text { UBL } & \text { Ugaritisch-biblische Literatur } \\ V E & \text { Vox evangelica } \\ V T & \text { Vetus Testamentum } \\ \text { VTSup } & \text { Supplements to Vetus Testamentum } \\ \text { WMNT } & \text { Wissenschaftliche Monographien zum Alten und Neuen Testament } \\ \text { ZAW } & \text { Zeitschrift für die alttestamentlich Wissenschaft } \\ \text { ZTK } & \text { Zeitschrift für Theologie und Kirche }\end{array}$




\section{INTRODUCTION}

\section{Narrative Obtrusions}

Narrative critics of the Hebrew Bible can describe the biblical narrators as "laconic," "terse," or "economical." Although they view the narrative from an omniscient perspective that gives them god-like knowledge of the events in the story, the narrators generally remain in the background, allowing the story to proceed while relying on characters and dialogue to provide necessary information to readers. On those occasions when these narrators add notes to their stories, scholars characterize such interruptions as asides. A narrative interruption occurs when the narrator steps out of the shadows and remarks on the story, perhaps by providing a historical reference or information about a character. Occasionally, the narrator may intrude in the text to comment on a situation. Jerome T. Walsh states that "sometimes the narrator will, so to speak, step out of the flow of the narrative to address the reader directly; the technical term for this is 'breaking frame,' and it changes the narrator's voice from that of a storyteller to that of a

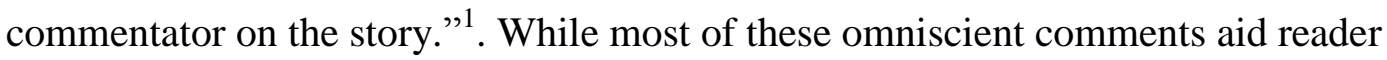
understanding, some of these interruptions actively attempt to shape the response of the reader. Obtrusions are omniscient comments employed by the narrator to address potential issues in the text that will create problems for the reader, either because of questions the narrator believes the reader may ask or because of the assumptions the narrator fears the reader may have.

\footnotetext{
${ }^{1}$ Jerome T. Walsh, Style \& Structure in Biblical Hebrew Narrative, (Collegeville, Minn.: Liturgical, 2001), 125 .
} 
Though narrative obtrusions are relatively rare, Robert Alter suggests that "special attention" be given to them. ${ }^{2}$ Those exceptional cases in which biblical narrators exchange the veil of reticence for the mantle of obtrusiveness create issues for readers. Readers may or may not recognize intrusions, but they are affected by them. Exegetical issues also arise. The exegete must determine whether the narrator is truly being obtrusive or is simply acting as an omniscient. Narrative motive must also be considered. If the narrator is usually terse, the reasoning behind a narrative interruption may not be so obvious. Determining how the deletion of an obtrusion affects the narrative reveals the narrator's impact on the story. This study explores the voice and motivations of the narrator by arguing that some intrusive elements, often characterized as redactions or asides by biblical scholars, are actually narrative obtrusions in which the narrator forcefully enters a narrative to reshape the text and sculpt the response of the reader.

Obtrusions serve as a key entry point into the world of the narrator and also highlight a significant intersection between the worlds of the narrator, the text, and the reader. In particular, this study seeks to amplify the narrator's voice in this discussion. While reader response puts a spotlight on the text and the reader, this study considers the way the narrator responds in advance to the reader by inserting obtrusions to prevent the reader from arriving at an unacceptable conclusion. ${ }^{3}$

The significance of this project lies in the fact that it builds upon a solid foundation of narrative criticism by seeking to understand how the character of the

\footnotetext{
${ }^{2}$ Robert Alter, The Art of Biblical Narrative (New York: Basic, 1981), 184.

${ }^{3}$ Whenever I refer to a reader response as unacceptable or questionable in this study, I am attempting to reconstruct the perspective of the narrator and am not making any personal judgments about the reader's ability to interpret the text.
} 
narrator may be glimpsed in obtrusions. For instance, in Mimesis, Eric Auerbach highlights the differences between biblical narrators and Homer, showing how the lack of emotions and adjectives in the biblical text creates feelings of suspense. ${ }^{4}$ The story of the binding of Isaac displays both the usual laconic style of the narrator as well as the narrator's intrusiveness. Auerbach notes the economy of the biblical narrator throughout the text. However, the narrative obtrusion at the beginning of the Aqedah cannot be ignored. By revealing that Abraham's binding of Isaac will ultimately be a test, the narrator shuts off many potentially unwelcome interpretive avenues. Figuring out why the narrator wanted to foreclose these possibilities at the beginning of the story while leaving others open throughout the narrative gives a sense of the biblical narrator's role in the text.

Meir Sternberg's The Poetics of Biblical Narrative has provided additional detail about the narrator by exploring the gaps created by the narrator. ${ }^{5}$ Different types of gaps may occur in narrative. In some cases, the narrator relies on the reader to fill in missing details. In other cases, a gap may be present in a story because the narrator fails to recognize it or because the narrator believes that the missing details are irrelevant to the story. Readers, however, may notice these gaps and asks questions about them. Some gaps are so wide that they are noticeable to many readers of a text. Other gaps may be so subtle that they are only perceived by a handful of readers. How well the narrator negotiates these gaps has a tremendous effect on reader response. The fact that the

\footnotetext{
${ }^{4}$ Eric Auerbach, Mimesis: Dargestellte The Representation of Reality in Western Literature $\left(50^{\text {th }}\right.$ Anniversary ed; Princeton, NJ: Princeton University Press, 2003); repr. of Mimesis (trans. Willard R. Trask; Princeton, NJ: Princeton University Press, 1953, 1973); trans. of Mimesis; dargestellte Wirklichkeit in der abendländischen Literatur (Berne: A. Francke, 1946).

${ }^{5}$ Meir Sternberg, The Poetics of Biblical Narrative: Ideological Literature and the Drama of Reading [book on-line] (Bloomington: Indiana University Press, 1987, accessed 15 December 2011); available from http://www.netlibrary.com/Details.aspx; Internet.
} 
narrator closes some gaps with obtrusions while leaving other gaps opens raises additional questions about the narrator's expectations of the reader.

This project also goes beyond earlier scholarship by redefining the nature of narrative interruptions. By identifying selected obtrusions in the Former Prophets and bringing them together, the present study defines various levels of omniscience, examines the narrator's relationship with the reader, and seeks to determine narrative intent. Finally, this study addresses some of the perceived deficiencies in narrative criticism by proposing a methodology for identifying obtrusions. I also cite examples from ancient Near Eastern (ANE) literature to show that this issue is not limited to Hebrew writing.

\section{Chapter Outlines and Limitations}

Chapter One reviews the history of narrative criticism, examining this methodology's relationship to several other exegetical methods, most specifically historical criticism and reader response. Although scholarship has often referred to historical criticism as literary criticism, historical critics rarely engage in literary analysis - in spite of the great potential in form criticism. Nevertheless redaction criticism presents an opportunity to bridge the gap between these methods. This study uses a broad definition of redaction, recognizing that redactions may have arisen at any time from the oral telling of a story to final edits, but makes no attempt to date these potential redactions. Furthermore, this search for the narrator's voice in the text focuses on comments directly made by the narrator and only briefly discusses the comments that narrators may put in the mouths of characters. 
After exploring the connections between redaction and narrative criticism, Chapter One challenges the idea that reader response and narrative criticism cannot work in concert. Since omniscient comments and obtrusions represent the narrator's preemptive actions to anticipated responses by the reader, this study creates a forum to examine the conversation between the narrator and the reader. To achieve greater focus, readers are defined as ancient or modern readers.

This reconsideration of narrative criticism's relationships with redaction criticism and reader response creates a strong foundation for my methodology in Chapter Two. I discriminate between omniscience and obtrusiveness by examining the essentiality and location of a potentially obtrusive comment. The narrator's goals in responding to the reader further aid in this delineation. Omniscient comments convey necessary information designed to assist reader understanding, whereas obtrusive statements attempt to form the response of the reader. The existence of obtrusions also raises the issue of how gaps function in a narrative and why the narrator chooses to foreclose some gaps with omniscient comments or obtrusions while leaving others open. My approach also relies on reception history since readers' discomfort with a passage may reveal the initial struggle faced by the biblical narrator. To round out the methodology, I consider the possibility that certain passages may seem obtrusive based on the choices of individual scholars in their translations and interpretations. Such a caveat is necessary in considering the anomalous nature of obtrusions.

To achieve more specificity, I employ my methodology in Chapter Three by examining a fine example of obtrusiveness. In Judg 14:4, the narrator describes Samson's desire for a Timnite woman as being "of the Lord" and thus opens the door for hostilities 
between Samson and the Philistines. The narrator breaks the frame of the story and inserts a comment about the divine to address a reader's question or assumption about Samson's choice. Statements about God often prove more obtrusive than general comments about history or characters. In yet other cases, the narrator may obtrude in order to protect the divine or another favored character in a narrative. Chapter Three also considers various responses to Judg 14:4 by ancient commentators and modern day scholars.

Chapter Four further explores the way the narrator envisions the reader and forecloses potential reader questions and assumptions. As an initial reader of a text, the narrator may theologize a popular story and add commentary; however, the narrator may object to responses in which the reader behaves similarly. This chapter considers additional ways that the narrator may obtrude in the text. Although obtrusions such as Judg 14:4 break the frame of a text, the narrator may employ non-break frame obtrusions by adding a comment after a break in action. The chapter concludes with an examination of David as a reader and narrator of his own story, examining his skill in reinterpreting events and revealing the problems that arise when he leaps into the gap in Nathan's parable.

Chapter Five presents a selective study of omniscience and obtrusiveness in ANE literature, particularly in the literary traditions of the Hurro-Hittites, the narrative poetry of Ugarit, the various genres of Mesopotamian literature, and in the first person narratives of ancient Egypt. The chapter contrasts the limited omniscience of ANE gods with the all knowing God of Jewish and Christian tradition, arguing that the biblical narrators more closely resemble ANE deities because they often lack knowledge. This chapter further 
solidifies the connections between narrative criticism and reader response by arguing that narrators compose their responses to readers based on the type of reader envisioned. Narrators, such as the Hurro-Hittites, trust their readers to understand the story they are telling and only use neutral omniscience, while the Mesopotamian narrator Kabti-ilāniMarduk uses obtrusions and other sophisticated literary devices. The chapter also examines the various manifestations of the voice of the narrator, exploring an emerging type of indirect free speech in Ugarit and considering the reader elevating asides employed by first person Egyptian narrators. The chapter considers a wide range of obtrusiveness, showing how narrators invoke the gods and even challenge the gods.

The range of obtrusiveness explored in this study, however, is limited to localized obtrusions in narratives and does not consider grand obtrusions that govern entire books or extended story lines that continue in multiple books. Such examples show that obtrusions not only break frame but can also reframe an entire series of narratives. For example, Judg 2 is a major obtrusion that reframes all of the stories within the book. Additionally, the story of the demise of the house of Eli carries over a good number of narratives, reappearing when Doeg kills the priests of Nob (1 Sam 22) and finally ending with Abiathar's banishment (1 Kgs 2:26-27). Although local obtrusions may affect other stories, they are less influential than obtrusions that reframe larger texts and narratives.

By distinguishing omniscience and obtrusiveness in local narratives and reconsidering the nature of narrative asides, this study provides a unique view into the world of the narrator. Amidst the vast amount of biblical scholarship that focuses on textual issues in historical criticism and the multitude of voices represented by reader oriented approaches, this study brings the often silent, and generally laconic voice of the 
narrator back into view. While the narrator wrestles with the text and attempts to force a particular perspective on the reader while foreclosing certain questions, this study struggles with the atypical actions of the narrator and hopes to open the door to more discussions. 


\section{CHAPTER I}

\section{NARRATIVE ECONOMY, ARTISTRY, AND THE LITERARY IMAGINATION}

"The Biblical narrative is of exemplary purity of line, sobriety and terseness. Not one superfluous word, not one useless gesture. The imagery is striking, the language austere, the dialogue so incisive, it leaves one with a knot in one's throat."6

Elie Wiesel, Messengers of God.

\section{Introduction}

Generations of scholars have recognized the artistic qualities of the Hebrew Bible, praising the biblical narrators for the depth of their writing style in spite of the terse nature of their work. But while historical criticism has ostensibly applauded the efforts of the narrators in its quest to uncover authorial intentions and origins in history, historical critics have often fallen short of addressing literary questions. Form criticism, particularly in the work of Hermann Gunkel, served as a possible foundation for narrative criticism by focusing on scenes, characters, and narrative structure, leaving historical critics with road maps to the literary world of the biblical text. However, many scholars have viewed this road as a one of many potential paths for new discoveries, limiting the form crticial

\footnotetext{
${ }^{6}$ Elie Wiesel, Messengers of God: Biblical Portraits and Legends $\left(1^{\text {st }}\right.$ Touchstone ed; New York: Simon \& Schuster, 1994), 80; repr. of Messengers of God (trans. Marion Wiesel; New York: Simon \& Schuster, 1976); trans. of Célébration biblique: portraits et légendes (Paris: Éditions du Seuil, 1975).
} 
discussion to genre and tying places and alleged composite characters to Tradition History. $^{7}$

I write, not to resurrect the quest for the historical author, but to look for evidence of the narrator's voice within the text and to examine the ways in which the narrator responds to potential reader questions and assumptions. By examining the narrator's anticipation of the reader's response and the way the narrator intrudes in the text, I construct a more complete picture of the narrator's worldview. The significance of narrative obtrusions lies in the fact that they bring the narrator, the text, and the reader together at crucial point within the narrative where the narrator has broken or reframed the text and inserted a comment that specifically attempts to influence the reader's response. Therefore narrative obtrusions serve as important intersections in interpretation. Far too often, various interpretive strategies have separated the text, narrator, and reader, creating new divides in biblical studies. Historical critics focus on the origins and intentions of the author. Scholars influenced by the New Critics concentrate on the text. Reader response began as a reactionary hermeneutic to the textually oriented New Critics and shifted the focus from the text to the reader. Although some scholars may not see the value of combining redaction criticism and narrative criticism and others may think that reader response and narrative criticism cannot work together, I utilize some of the best parts of each of these methods and show that they are compatible with narrative criticism by examining the issues of narrative economy, textual unity, and literary artistry and imagination. To discover the scholarly origins of narrative criticism and lay a foundation

\footnotetext{
${ }^{7}$ François Tolmie, Narratology and Biblical Narratives: A Practical Guide (San Francisco: International Scholars, 1999), 2.
} 
for my methodology, this chapter focuses on the history of narrative criticism, contrasting narrative criticism and historical criticism while examining the former's relationship with reader response.

I begin by exploring the portrait of the biblical narrator and reviewing the history that led to the formation of narrative criticism. I consider the ways in which renowned biblical scholar and form critic Hermann Gunkel's The Legends of Genesis (1901) both paved the way for narrative criticism and created a few obstacles for it to overcome. ${ }^{8} \mathrm{I}$ stress the important work of literary critic Erich Auerbach whose Mimesis (1946) defined the biblical narrator and helped redefine the concerns of biblical scholarship by bringing literary analysis into the discussion. ${ }^{9}$ Next, I examine Jewish interpreters and modern canonical critics as proponents of textual unity, a foundational point for narrative criticism since this methodology connects narrative cohesiveness with narrative artistry. The methodology of narrative criticism began in New Testament (NT) Studies in the 1970's and culminated in two works that brought narrative criticism in full force to biblical studies in the 1980's: literary critic Robert Alter's The Art of Biblical Narrative (1981) and the collaborative work of NT scholar David Rhoads and English literature professor Donald Michie, Mark as Story (1982). ${ }^{10}$ I build on this foundation by

\footnotetext{
${ }^{8}$ Hermann Gunkel, The Legends of Genesis, The Biblical Saga and History (Whitefish, Mt.: Kessinger, 2006); repr. of The Legends of Genesis (trans. W. H. Carruth; New York: Schocken Books, 1964); trans. of Die Sagen der Genesis (Chicago: Open Court Publishing, 1901). See also Hermann Gunkel, Genesis (HKAT; Göttingen: Vandenhoeck and Ruprecht, 1901).

${ }^{9}$ Auerbach, Mimesis.

${ }^{10}$ Alter, The Art of Biblical Narrative. David M. Rhoads, and Donald Michie, Mark as Story: An Introduction to the Narrative of a Gospel (Philadelphia: Fortress, 1982; repr., Minneapolis: Fortress, 1999). Just as Auerbach did not have a background in biblical studies, Alter's academic roots lie in modern European literature. See also Mara H. Benjamin, "The Tacit Agenda of a Literary Approach to the Bible," Prooftexts 27 (2007): 254-74.
} 
discussing other narrative scholars and by highlighting various insights on narrative omniscience and obtrusiveness in their work.

\section{Narrative Criticism}

The relatively recent method of narrative criticism marks a new journey in the field of biblical studies, an expedition that diverges in many different directions as it explores new strategies in an attempt to lead scholarship beyond historical concerns. Narrative criticism embraces the textual unity of canonical criticism while historical criticism holds fast to textual divisions that arose from multiple sources and editors. ${ }^{11}$ Narrative criticism admits the existence of sources and redactions but chooses to focus on the artistic weaving of these materials into a sustained narrative picture.

Although historical critics and narrative critics disagree on the level of artistry displayed by the biblical narrators, they both recognize the narrators' succinct style, creating an opportunity to show that narrative comments previously characterized as simple asides may reveal an obtrusive narrator working within the text, attempting to influence the response of the reader. The comments made by these often silent narrators merit more discussion than scholarship has afforded them since they offer a window into the worldview of the narrator. And if narrative economy and narrative unity make the text a work of art as narrative critics suggest, then scholars must begin to wrestle with the

\footnotetext{
${ }^{11}$ David Norton, A History of the Bible as Literature (revised ed.; Cambridge, U.K; New York: Cambridge University Press, 2000). In writing about narrative criticism, Steven Weitzman notes that "However newfangled it seemed in the 1980's, the 'literary approach' to the Bible, the attempt to understand it as a work of aesthetic and not just religious or historical value, is as old as most other methods of biblical study" ("Before and After The Art of Biblical Narrative," Prooftexts 27 [2007]: 191-210).
} 
question of whether or not a narrative obtrusion diminishes the artistic prowess of the biblical narrator. $^{12}$

Ironically, historical criticism has often gone by the moniker "literary criticism" despite being almost entirely different from the method practiced in English Literature. Therefore I follow the lead of Cheryl Exum and David Clines in referring to historical criticism as Literarkritik, noting the significant accomplishments that occurred in the Graf-Wellhausen Hypothesis and Noth's The Deuteronomistic History while pointing out the differences between Literarkritik and new forms of literary criticism. ${ }^{13}$ Clines and Exum explain that "the 'new' literary criticism of the Hebrew Bible, whatever form it takes, has almost nothing in common with Literarkritik. It is not a historical discipline, but a strictly literary one."14 Narrative criticism represents one of the first waves of this new literary criticism; but its foundations in form criticism also represent the road less traveled, a path laid out by Gunkel that biblical scholars have only recently begun to traverse.

François Tolmie praises Gunkel for bringing "narratological analysis" into biblical studies, but quickly points out that the discipline largely ignored this method. ${ }^{15}$

\footnotetext{
${ }^{12}$ Weitzman describes the artfulness of narrators with regard to the way the Bible "orchestrates sound, repetition, dialogue, allusion, and ambiguity to generate meaning and effect." $\mathrm{He}$ also notes that the close reading style of Alter had as "its chief objective the elucidation of their artistic design" ("Before and After," 191, 196).

${ }^{13}$ J. Cheryl Exum, and David J. A. Clines, eds., The New Literary Criticism and the Hebrew Bible (JSOTSup 143; Sheffield: JSOT Press, 1993), 11-12.

${ }^{14}$ Clines \& Exum, The New Literary Criticism, 11-12. Clines and Exum define "the new literary criticism" as "all the criticisms that are post-structuralist ... the theoretical approaches that have come into the limelight in literary studies generally in the 70s and 80s [including Narrative Criticism], and that can be expected to influence the way we read the Hebrew Bible in the present decade" (12).

${ }^{15}$ Tolmie, Narratology and Biblical Narratives, 2. In her introduction to Mytharion: Comparison of Tales from the Old Testament and the Ancient Near East, Dorothy Irvin discusses the lack of methodological
} 
Nevertheless Gunkel contributes to the portrait of the narrator by showing the narrator's terse nature and objectivity in the opening chapters of Genesis. ${ }^{16}$ For example, the narrator never addresses potential questions of modern readers such as what Adam and Eve thought before eating the fruit. Gunkel traces the origin of this concise style of biblical narrative to an oral context where a storyteller used performance art to provide the emotions missing in the text. During Gunkel's time, biblical scholarship generally proved unfavorable to literary concerns. Narrative issues have probably always rested on the periphery of biblical studies; but a literary critic, limited by the circumstances of a horrible war, renewed literary interest in the Bible and proclaimed the Hebraic narrators' artistic equality to Greek counterparts like Homer.

\section{Eric Auerbach and Mimesis}

Forcibly exiled from Germany because of World War II, Auerbach found refuge in Istanbul where the limitations of its libraries compelled him to deal with primary texts. One of the first among many scholars to connect narrative artistry with narrative economy, Auerbach studied the return of Odysseus alongside the binding of Isaac. In the Aqedah, Auerbach discovered a beautiful example of the economy and artistry of the Bible. In writing about the beauty of biblical narrative, Auerbach describes Old Testament characters as "more fully developed" and "much more distinct as individuals, than are Homeric heroes"; he concludes that "Achilles and Odysseus are splendidly

\footnotetext{
development in narrative studies of the Old Testament beyond Gunkel, noting that his students Hugo Gressmann and Walter Baumgartner focused on areas other than narrative and folklore (AOAT 32; Kevelaer: Butzon und Bercker; Neukirchen-Vluyn: Neukirchener Verlag, 1978), xii-xv.

${ }^{16}$ Gunkel, The Legends of Genesis, 60-61.
} 
described in many well-ordered words, epithets cling to them, their emotions are constantly displayed in their words and deeds - but they have no development, and their life-histories are clearly set forth once and for all." ${ }^{17}$ While the Bible presented characters free to grow and change, Homeric characters remained inextricably melded to their destiny. By generally omitting comments about the thoughts or emotional state of a character, the biblical narrator drew readers into the text. ${ }^{18}$ Alter observes that "Auerbach stressed the background-fraught sparseness of biblical narrative both as the key to the sense of depth in its representation of reality and as the explanation for the endless interpretation the Bible has engendered."19 This inextricable link between the narrator's economy and artistry brought literary questions to light.

Alter believes that Auerbach's essay "Odysseus' Scar" "could be taken as the point of departure for the modern literary understanding of the Bible" since Auerbach's work challenged the inaptly named literary criticism of the Hebrew Bible to make way for the truly literary analysis of biblical scholarship. ${ }^{20}$ Even though he was not a biblical scholar, Auerbach encouraged others to view biblical characters as literary figures, challenging Gunkel's idea of composite characters, which focused on historizing constructions of figure rather than a character's literary function. ${ }^{21} \mathrm{He}$ also promoted the idea of textual unity, a tradition among Jewish exegetes, that later became a foundational

\footnotetext{
${ }^{17}$ Auerbach, Mimesis, 16-18.

${ }^{18}$ For more comparisons between Homer and the Bible, see Shmuel Abramski, "חידישי מקרא וחקרי קדמוניות" Beth Mikra 7 (1963): 122-27.

${ }^{19}$ Robert Alter, The World of Biblical Literature (New York: Basic, 1992), 87.

${ }^{20}$ Alter, The World of Biblical Literature, 66-67.

${ }^{21}$ Auerbach, Mimesis, 16-18.
} 
point for Brevard Childs' canonical criticism and subsequently an important building block in the formation of narrative criticism. ${ }^{22}$

The Unity and Economy of the Biblical Text

The Precursors of Canonical Criticism

Although canonical criticism began with Childs' Biblical Theology in Crisis

(1970), others preceded Childs in expressing a belief in the unity and sacredness of the text. The idea of textual unity enhances the proposal that the biblical narrators acted as meticulous artists rather than rambling raconteurs. Edward Greenstein lists the "classical midrashim” along with Martin Buber's On Judaism (1919) as well commentaries on Genesis by Benno Jacob (1934) and Umberto Cassuto (1941) as the Jewish precursors of the canonical criticism that arose among Christian scholars in the 1970's. ${ }^{23}$ These Jewish and Christian scholars deemed acceptance of a unified text as aiding in the

\footnotetext{
${ }^{22}$ Gerald T. Sheppard notes that Childs does not approve of the term "Canonical Criticism" even though "he may still be regarded by others scholars as [one of] its leading practitioners" ("Canonical Criticism," $A B D$ 1:861-66).

Homer's works have also created questions about narrative unity, dividing scholars into Analysts and Unitarians as they attempt to answer the Homeric Question. See Jacqueline De Romilly, A Short History of Greek Literature (Chicago: University of Chicago Press, 1985), 7-9.

${ }^{23}$ Edward L. Greenstein, Essays on Biblical Method and Translation (BJS 92; Atlanta: Scholars, 1989), 36. See Martin Buber, On Judaism (ed. Nahum N. Glatzer; New York: Schocken, 1967). Umberto Cassuto, A Commentary on the Book of Genesis: From Adam to Noah (2 vols.; Publications of the Perry Foundation for Biblical Research in the Hebrew University of Jerusalem; Jerusalem: Magnes, Hebrew University, 1989); repr. of A Commentary on the Book of Genesis (trans. by Israel Abrahams; $1^{\text {st }}$ English ed.; Magnes,

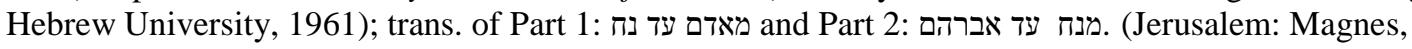
Hebrew University, 1944, 1953, 1959). Benno Jacob, The First Book of the Bible: Genesis, Augmented Edition (ed., abr., and trans. Ernest I. Jacob and Walter Jacob; New York: Ktav, 2007); trans. of Das erste Buch der Torah, Genesis (Berlin: Schocken Verlag, 1934). For more on the connection between Jewish interpretive tradition and literary studies of the Bible, see Weitzman, "Before and After," 193.
} 
comprehension of the Bible. ${ }^{24}$ In contrast, historical criticism challenged the artistry and sacredness of the text. Therefore some may argue that claims about narrative unity represent efforts to make divine inspiration the vehicle for proving the hallowed nature of the text. However, many who hold fast to a belief in the sacredness of the text often object to classifying the Bible as literature, preferring to continue their quest to prove its historicity. $^{25}$

Canonical criticism has both theological and literary roots. Its origins are found in the tenet of sola scriptura in Protestant Christianity as well as in the methodologies of structuralists, rhetorical critics, and the New Critics (Formalists) who arose in the 1940's and 50's. ${ }^{26}$ These new methods shared a holistic view of the text, distinguishing them from historical criticism because they approached the text "as a meaningful whole containing the essential elements of its own understanding rather than as understandable only as the product of an historically determined process of composition."27 And, yet,

\footnotetext{
${ }^{24}$ Benjamin notes that Buber and Rosenzweig "did not deny the claims made by higher criticism, but aimed to limit its significance for communities and readers of faith" ("The Tacit Agenda," 257). For more on the Bible and Jewish scholars, see S. David Sperling, ed., Students of the Covenant: A History of Jewish Biblical Scholarship in North America (Confessional Perspectives Series; SBL; Scholars Press, Atlanta, 1992).

${ }^{25}$ John J. Collins, The Bible after Babel: Historical Criticism in a Postmodern Age (Grand Rapids: W. B. Eerdmans, 2005), 136. The Biblical Theology movement also championed the idea of textual unity, but it went further than the scope or position of our study by claiming the unity of both testaments. See Brevard Childs, Biblical Theology in Crisis (Philadelphia: Westminster, 1970), 36. The generation of scholars that included von Rad characterized the Old Testament as history, but G. Ernest Wright's Biblical Theology Movement also viewed the Bible in historical terms. For a discussion of the difficulty involved in answering historical questions and the resulting potential in literary studies, see Philip R. Davies, In Search of 'Ancient Israel' ( $2^{\text {nd }}$ ed. JSOTSup148; Sheffield: Sheffield Academic, 1992), 11-16. Perhaps this potential has not been fully realized due to deconstruction as I discuss later in this chapter.

${ }^{26}$ Brevard Childs, Introduction to the Old Testament as Scripture $\left(1^{\text {st }}\right.$ American ed.; Philadelphia: Fortress, 1979), 74.

${ }^{27}$ David M. Gunn, "Narrative Criticism," in To Each Its Own Meaning: An Introduction to Biblical Criticisms and Their Applications (ed. Stephen R. Haynes and Steven L. Mackenzie. Revised and exp. ed. Louisville: Westminster John Knox, 1999), 201-29. For more on the idea of textual unity and literary
} 
they differed with each other in some ways: "to many structuralists the readings of those influenced by New Criticism seemed to lack rigor, more art than method, and to many of the later critics' structuralist analyses seemed arcane and rigid."28 These differences illumine the problem of narrative criticism evolving from a movement that seemingly lacked methodology. But sometimes new approaches that challenge the status quo garner disapproval because their emerging methodology needs more time to fully form.

Canonical criticism moved biblical studies in a new direction by focusing on the text rather than the author. The Intentional Fallacy advocated by the New Critics regarded the quest for the historical author unnecessary since "any attempt to determine the author's aims and purpose in writing was merely a distraction, for the text was considered to be a free-standing and self-sustaining entity and was regarded as the repository of its own meaning." ${ }^{29}$ Childs also focused on the text, formulating his methodology by utilizing narrative economy to shift attention away from the historical author. He writes, "But basic to the canonical process is that those responsible for the actual editing of the text did their best to obscure their own identity. Thus the actual process by which the text was reworked lies in almost total obscurity. "30 The anonymity of the author reveals the difficulty of distinguishing between redactor and narrator. The biblical narrators not only sought to hide themselves, but text centered scholarship allowed them to remain in the

\footnotetext{
artistry in Russian formalism, see Sergej Bernstein, "Ästhetische Voraussetzungen einer Theorie der Deklamation," in Texte der Russichen Formalisten (2 vols.; Munich: Wilhelm Fink, 1972) 338-85.

${ }^{28}$ Gunn, "Narrative Criticism," 204.

${ }^{29}$ Eryl W. Davies, The Dissenting Reader: Feminist Approaches to the Hebrew Bible (Aldershot, Hants, England; Burlington, Vt.: Ashgate, 2003), 37-38.

${ }^{30}$ Childs, Introduction to the Old Testament, 78.
} 
shadows, creating an atmosphere where scholars ignored narrative obtrusions or casually referred to them as asides.

\section{Literary Economy and Narrative Artistry}

An examination of narrative artistry helps to bring the narrators out of the shadows. Scholars who study the Bible as literature believe that not only the unity of the text, but also the economy of the narrative makes the text a work of art. In The Biblical Narrative (1959), Zvi Adar combines both of these elements to reveal narrative artistry and the lack of obtrusiveness in the Bible: "Once the narrator has opened the subject itself he does not stray either to the right or to the left, and only occasionally introduces an incidental remark in so far as it is required for the understanding of what is happening . . the biblical story is a classic example of an organic unity, a true artistic creation." ${ }^{31}$

For Adar, unity and economy are essential components of narrative artistry. But if Adar finds artistry in the economy of the biblical text, then any potential narrative obtrusion may detract from the narrator's brilliance. However, if textual artistry can withstand a narrative obtrusion, then the narrator's creativity may shine forth even more brilliantly.

Most scholars, however, have linked narrative obtrusions with redaction criticism. The numerous redactions proposed for the text often lead modern scholars to wonder how their predecessors discerned edits such as $R_{1}, R_{2}, R_{3}$, etc. and also where the list of possible redactions ends. As a part of historical criticism, redaction criticism could serve

\footnotetext{
${ }^{31}$ Zvi Adar, The Biblical Narrative (Jerusalem: Dept. of Education and Culture, World Zionist Organization, 1959), 55-56; trans. of ha-Sipur ha-Mikrai (Yerushalayim: ha-Mahlakah le-hinukh ule-tarbut ba-golah shel ha-Histadrut ha-Tsiyonit ha-'Olamit, 1957). In this quote, Adar writes about a narrator's "incidental remark." Later we will discuss whether these remarks are incidental or whether they may reveal an obtrusive narrator.
} 
as a potential stumbling block to narrative analysis; but if scholars employ redaction to answer literary questions rather than historical ones, then redaction criticism provides a nice foundation for narrative criticism. Still, Literakritik's concern for historical queries remains an issue.

\section{The Emergence of New Literary Criticism}

In Irony in the Old Testament (1965), Edwin Good noted problems with Literarkritik's definition of literary criticism: "Biblical Critics are not, generally speaking, literary critics. We have taken literary criticism to mean the distinction of sources, the analysis of forms, the separation of secondary from primary materials, and theological exegesis. These are all worthwhile and necessary tasks, but they do not comprise literary criticism. We have failed, however, to raise the genuinely literary questions about the Bible.", ${ }^{32}$ Good states, "the Bible is literature, whatever else it may be. ${ }^{33}$ Nevertheless many scholars have so concerned themselves with history that they often ignore the literary qualities of the text.

Furthermore, while Good's book addresses irony in the Old Testament, his preface reveals the irony of a discipline incorrectly calling its work literary criticism while ignoring many literary aspects of the text in favor of historical pursuits. Because he had seen the suppression of literary questions in historical criticism, Good opposed

\footnotetext{
${ }^{32}$ Edwin Good, preface to Irony in the Old Testament $\left(2^{\text {nd }}\right.$ ed.; Bible and Literature Series 3; Sheffield: Almond, 1981), 9-10.

${ }^{33}$ Good, "Preface," 9-10.
} 
creating a new literary school to compete with historical criticism, feeling that such an approach would become too limited in vision to ask the right questions. ${ }^{34}$

In the end, the lack of a school may have caused new forms of literary criticism to grow. Historical critics have often decried new literary criticism's lack of an appropriate method to center scholarly work due to its penchant for utilizing such diverse forms of analyses. While detractors call attention to this negative aspect, proponents view this openness to exploration as one of driving forces behind the development of new literary criticism. ${ }^{35}$ Narrative criticism's receptivity to the ideas of other exegetical methods creates opportunities for incorporating historical criticism with new literary criticism. In spite of the seeming incompatibility between historical and narrative criticism, form and redaction criticism have significant literary potential.

Pairing these methods with narrative criticism may reveal that other types of exegesis may be more compatible with narrative criticism than some may think. For example, reader response and narrative criticism may seem mismatched because the latter "ascribed to the biblical author or editor a mastery, a control over the meaning of the biblical text, at a time when many scholars were shifting focus to readers and how they impose meaning on the text." ${ }^{, 36}$ Additional differences between the two arise because "typically, reader-response methods focus on ways in which interpretation of a text may be shaped to fit the interests or circumstances of diverse readers. Without denying these

\footnotetext{
${ }^{34}$ Good, "Preface," 9-10. Like others before him, Good points out form criticism's unrealized potential, calling the method "a step in the right direction" which failed because it "used literary observations for nonliterary purposes."

${ }^{35}$ See Clines \& Exum, The New Literary Criticism, 12.

${ }^{36}$ Weitzman, "Before and After," 200.
} 
interpretive possibilities, narrative criticism tries to determine how various signals within a text guide the readers in deciding what the text means. ${ }^{, 37}$ This study of narrative obtrusiveness may help to bring these approaches together because obtrusions represent areas where the narrator actively attempts to influence the thinking of the reader. While a narrator generally endeavors to affect the thinking of the audience, sufficient consideration must be given to those instances where a normally laconic narrator interrupts the flow of the text in an attempt to change the way a reader interprets a story, an event, or a character.

Furthermore, biblical scholars can more easily balance the concerns of narrative criticism and reader response "since the distinctions between 'implied author' and 'narrator' and between 'implied reader' and 'narratee' is practically irrelevant in most of the Biblical narratives," creating greater opportunities to focus on the narrator and the reader. ${ }^{38}$ This lack of distinction reveals the differences between the Bible and other forms of literature while demonstrating the promise of using narrative criticism and reader response collaboratively.

\footnotetext{
${ }^{37}$ Mark A. Powell, "Narrative Criticism," in Methods of Biblical Interpretation: Excerpted from the Dictionary of Biblical Interpretation (ed. John H. Hayes; Nashville: Abingdon, 1999), 169-72. Powell further notes that "in practice, the two approaches often appear to be in conflict, but the distinction is primarily one of degree and emphasis" (169).

For more on the relationship between the reader and the narrator in the Hebrew Bible, see Jean Louis Ska, Jean-Pierre Sonnet, and André Wénin, "L’Analyse narrative des récits de l'Ancien Testament" Cahiers Évangile 107 (1999): 1-66.

${ }^{38}$ Jean Louis Ska, "Our Fathers Have Told Us": Introduction to the Analysis of Biblical Narratives (SubBi 13; Roma: Editrice Pontifico Istituto Biblico, 1990), 42. The case is the same for both testaments in biblical studies. Elizabeth S. Malbon states that in NT studies, "most narrative critics have observed little or no difference between the implied author and narrator or between the narratee and implied reader of" the gospels ("Narrative Criticism: How Does the Story Mean?" in Mark and Method: New Approaches in Biblical Studies [ed. Janice C. Anderson and Stephen D. Moore; ${ }^{\text {nd }}$ ed. Minneapolis: Fortress, 1992; repr. Minneapolis: Fortress, 2008], 29-58).
} 


\section{Narrative Criticism and Reader-Oriented Approaches}

Bridging the gap between narrative criticism and reader response leads to questions about the relationship between narrative criticism and reader-oriented approaches like feminist criticism. In contrast to reader response, these methods focus on the different types of readers who may engage a text. Narrative criticism may lack compatibility with these approaches because it "does not specifically take into account the agenda of the reader ... since the method focuses on generating from the narrative rather than on filtering it through political, social, or aesthetic convictions of the reader. ${ }^{, 39}$ However, on the positive side, "it does provide narrative data that can then be analyzed from the perspective of the reader." ${ }^{40}$ I admit a potential conflict between my approach and reader-oriented approaches. For example, choosing to view a narrative obtrusion through the eyes of feminist criticism may limit the possible reasons behind the narrator's motivations. Or, categorizing a narrator's comments as polemics against women may not give sufficient attention to characterization and may ignore other intriguing possibilities. ${ }^{41}$

\footnotetext{
${ }^{39}$ Richard G. Bowman, "Narrative Criticism: Human Purpose in Conflict with Divine Presence," in Judges and Method: New Approaches in Biblical Studies (ed. Gale A. Yee; Minneapolis: Fortress, 1995; repr. Minneapolis: Fortress, 2007), 17-44.

${ }^{40}$ Bowman, "Narrative Criticism," 20.

${ }^{41}$ Narrative criticism opposes readings that become too focused on a particular ideology, even going so far as to criticize the rabbinic tendency to base interpretations on instructive homilies. For an example of a feminist reader-oriented approach which utilizes countercoherence and deconstruction, see narratologist and feminist critic Mieke Bal, Death and Dissymmetry: The Politics of Coherence in the Book of Judges (CSJH; Chicago: University of Chicago Press, 1988).
} 
Narrative Criticism and Deconstruction

Reader-oriented approaches lead to another methodology that creates problems for narrative criticism — deconstruction. Gunn believes that "the exploration of texts from a reader-oriented perspective ... has been a cutting edge of Hebrew Bible narrative studies ... particularly where critics are taking account of the ideological dimensions and deconstructive possibilities of reading. ${ }^{, 42}$ However, because of its foundation in textual unity, narrative criticism largely proves incompatible with deconstruction. The two also differ in that narrative criticism "acknowledges ambiguities and even multiple meanings but attributes them to the complexities of characters and the intricacies of events, complexities and intricacies that do not create unresolvable confusion and irretrievable significance. ${ }^{, 43}$ Narrative criticism's incompatibility with deconstruction is somewhat similar to its issues with historical criticism.

Both historical critics and deconstructionists challenge textual unity, albeit for different reasons. Historical critics use source and redaction criticism to point out the disparate parts of the text. By its very nature, deconstruction demolishes the text and challenges the artistry that may come from multiple meanings. Nevertheless narrative criticism follows canonical criticism in maintaining the coherence of the text in its final form. And although narrative criticism and deconstruction lack compatibility, narrative criticism spans the gap between the Hebrew Bible and the NT, encouraging literary study of both testaments.

\footnotetext{
${ }^{42}$ Gunn, "Narrative Criticism," 208.

${ }^{43}$ Bowman, "Narrative Criticism, 20.
} 


\section{The New Testament and Narrative Criticism}

Although the NT follows the Hebrew Bible in history, narrative criticism of the NT arose in the 1970's, preceding Hebrew Bible scholarship on the topic by a full decade. ${ }^{44}$ This earlier beginning may have solidified the method in NT studies more than in Hebrew Bible scholarship as Gunn notes, “The term 'narrative criticism' in biblical studies is a loose one, more found in New Testament than in Hebrew Bible studies" in spite of the larger number of narratives in the latter. ${ }^{45}$ Stephen D. Moore credits the Markan SBL Seminar of the 1970's, structuralism, and Semeia with fostering the growth of narrative criticism in NT studies. ${ }^{46} 1980$ marked the final year of the decade long SBL Seminar on Mark which yielded David Rhoads' paper "Narrative Criticism and the Gospel of Mark," a work which "surveyed the nonstructuralist literary work on Mark of the 1970s," resulting in "the first time the approach is programmatically labeled narrative criticism." ${ }^{, 47}$

Later Rhoads and Michie's Mark as Story (1982) recognized the nature of an effaced narrator in Mark (perhaps influenced by the narrators of the Hebrew Bible); but they nonetheless claimed that such a narrator could persuade a reader by means of cleverly and artistically employed asides. Such asides engendered the reader's confidence, allowing the narrator to affect reader response in other areas of the story

\footnotetext{
${ }^{44}$ Tolmie, Narratology and Biblical Narratives, 3-4.

45 Gunn, "Narrative Criticism," 201.

${ }^{46}$ Stephen D. Moore, Literary Criticism and the Gospels: The Theoretical Challenge (New Haven: Yale University Press, 1989), 7. For an entire journal issue focusing on the SBL Narrative Research Group (1979-1984), see "Narrative Research on the Hebrew Bible," Sem 46 (1989): 3-179.

${ }^{47}$ Moore, Literary Criticism and the Gospels, 7. See David M. Rhoads, "Narrative Criticism and the Gospel of Mark," JAAR 50 (1982): 411-34.
} 
since the narrator proved so valuable at providing information. ${ }^{48}$ Even though this project focuses on the Hebrew Bible, Rhoads' and Michie's depiction of the biblical narrator's effective use of asides lends support to this study of narrative obtrusion. ${ }^{49}$

Gunn describes recent work on narrative in each area of biblical studies as "parallel" but "distinct," characterizing NT narrative criticism as different from similar work in the Hebrew Bible because the former is "relatively conservative in its methodology, concerned with observing the mechanics or artistry of literary construction, [and] the conventions of ancient rhetoric." ${ }^{50}$ Still, the similarities support the use of ideas from each discipline, especially since they share a common origin. Although several factors led to the rise of narrative criticism in NT studies, Moore finds the primary impetus for the movement in "a profound disgruntlement with the hegemony of historical criticism." However, historical criticism has also proven foundational for future narrative work since many NT narrative critics have made redaction criticism a valuable partner in literary studies.

This changing view of redaction criticism in NT studies has contributed to the growth of narrative criticism. In 1989 Moore wrote, "the current research climate, where the quest for theological unity in the Gospels (intensifying as redaction criticism turns a slow corner from a primary emphasis on the evangelists' modification of their sources to

\footnotetext{
${ }^{48}$ Rhoads and Michie, Mark as Story, 39-41.

${ }^{49}$ For works on narrative asides in the New Testament, see Steven M. Sheely, Narrative Asides in LukeActs (JSNTSup 72; Sheffield: JSOT Press, 1992); and Dal Lee, The Narrative Asides in the Book of Revelation (Lanham, Md.: University Press of America, 2002).

${ }^{50}$ Gunn, "Narrative Criticism,” 202.

${ }^{51}$ Moore, Literary Criticism and the Gospels, 7. Gunn believes that NT narrative criticism is "often still haunted by historical criticism's need to know the author's 'intention' and the text's 'original' readership if it is to speak legitimately of the text's meaning" ("Narrative Criticism," 202).
} 
an emphasis on their compositional creativity) is coupled with the quest for narrative unity in the Gospels." ${ }^{52}$ Again, a connection between and narrative unity and artistry appears. This link does not ignore possible redactions but accounts for them in different ways. ${ }^{53}$ Just as narrative critics of the Hebrew Bible claim narrative unity in spite of potential sources, NT scholars recognize the source material at the evangelists' disposal but argue that they create coherence rather than confusion. ${ }^{54}$

\title{
Robert Alter and The Art of Biblical Narrative
}

While NT studies on narrative criticism generally preceded similar work on the Hebrew Bible, Alter's The Art of Biblical Narrative (1981) was published the year before Rhoads and Michie's Mark as Story. ${ }^{55}$ Both The Art of Biblical Narrative and Alter's more recent book The World of Biblical Literature (1992) discuss the need for narrative approaches to the Hebrew Bible while pointing out the stumbling blocks and stepping stones created by historical criticism, particularly in form criticism.

\footnotetext{
${ }^{52}$ Moore, Literary Criticism and the Gospels, 29.

${ }^{53}$ Moore, Literary Criticism and the Gospels, 30. When discussing Robert C. Tannehill's The Narrative Unity of Luke-Acts: A Literary Interpretation, (FF; Philadelphia: Fortress, 1986), Moore states that "Tannehill is well aware that Luke-Acts is not a seamless weave but is imperturbably confident nonetheless that the evangelist is in full control of his materials" (30).
${ }^{54}$ For articles on narrative in the Hebrew Bible and the New Testament, see Camille and André Wénin, ed., Analyse Narrative et Bible: Deuxiè Colloque International Du Rrenab, Louvain-La-Neuve, Avril 2004 (BETL 191; Leuven, University Press; Dudley, Mass: Peeters, 2005).

\begin{abstract}
55 For the origins of The Art of Biblical Narrative, see Alter, Art, x-xi. In writing about the NT, Alter notes the existence of "certain literary as well as theological continuities between the Hebrew Bible and the New Testament, but the narratives of the latter were written in a different language, at a later time, and by and large, according to different literary assumptions. It therefore does not seem to me that these two bodies of ancient literature can be comfortably set in the same critical framework, and, in any case, I would not have the linguistic and scholarly competence to deal with the New Testament" (Art, ix). For an entire journal issue devoted to the impact and continuing promise of The Art of Biblical Narrative, see Prooftexts 27 (Spring 2007): 191-370. For articles from a symposium on Alter's work, see Robert Boling, ed., "Biblical Narrative in New Perspective," BR 31 (1986): 6-25.
\end{abstract}


Narrative critics have taken issue with form critics who failed to see the literary potential inside their exegetical technique. Like Auerbach, Alter characterizes Gunkel's tendency to transform biblical figures into eponymous ancestors as "the flattening effect of some historical scholarship." ${ }^{, 56}$ As an alternative, he proposes viewing these figures as "individual characters surrounded by multiple ironies, artfully etched in their imperfections as well as their strengths. ${ }^{.57}$ Examing the characterization of a figure in a text proves valuable to my methodology and shows the literary potential in form criticism.

Alter also challenges form criticism's propensity to study the social context of a text while disregarding its literary power. For example, type scenes represent forms that inherently communicate information to readers. A well is a good place for a man to meet a woman, and both Jacob and Moses meet their future brides at a well. Literary aspects like type scenes reveal the ways ancient individuals understood the conventions of their world. Conventions represent "an elaborate set of tacit agreements between artist and audience about the ordering of the art work ... [and] the enabling context in which the complex communication of art occurs. ${ }^{58}$ Since form criticism "uses these patterns for excavative ends - to support hypotheses about the social functions of the text, its

\footnotetext{
${ }^{56}$ Alter, The Art of Biblical Narrative, 23.

${ }^{57}$ Alter, The Art of Biblical Narrative, 22.

${ }^{58}$ Alter, The Art of Biblical Narrative, 47.
} 
historical evolution, and so forth," Alter prefers literary analysis of a story's setting over a discussion of social location. ${ }^{59}$

Despite Alter's problems with historical criticism, he never dismisses the arguments that various source materials were involved in the creation of the text. In fact, he recognizes two key problems narrative critics must address: "the peculiar circumstances of the composition and evolution of the biblical text; and the peculiar aims, even the peculiar objects of representation, toward which the literary art of the Bible is directed. ${ }^{, 60}$ Alter describes the biblical narrator's use of source material as an attempt "to respect the textual integrity of embedded material and not to trouble about any minor discrepancies with the surrounding story that might ensue. ${ }^{, 61} \mathrm{He}$ opposes deconstruction by citing Russian Formalists and the New Critics as support for the idea that "even mutually contradictory perceptions of the same object can be fused within a single linguistic structure. ${ }^{.62}$ Therefore narrative critics recognize various sources while highlighting the weaving of these sources into a unified text.

\footnotetext{
${ }^{59}$ Alter, The Art of Biblical Narrative, 47-48. For a similar idea, see Wolfgang Richter who discusses the science of literature while moving away from the concerns of historical criticism, particularly by focusing on the setting of the story rather than its Sitz im Leben (Exegese als Literaturwissenschaft: Entwurf einer alttestamentlichen Literaturtheorie und Methodologie [Göttingen: Vandenhoeck and Ruprecht, 1971], 72 125).
}

${ }^{60}$ Alter, The World of Biblical Literature, 1-2. For more on Alter's view of the Documentary Hypothesis and the composite nature of the Deuteronomistic History, see Alter, The Art of Biblical Narrative, 132. He dates the Torah and the Deuteronomistic History to the pre-exilic period while recognizing the lateness of Esther and Daniel (Alter, Art, ix).

${ }^{61}$ Alter, The World of Biblical Literature, 16.

${ }^{62}$ Alter, The Art of Biblical Narrative, 153. Alter admits the difficulty of finding narrative unity in some passages. In spite of the possibility of "intrinsic incoherence," he states that "my own experience as a reader makes me suspect that such insoluble cruxes deriving from the composite nature of the text are a good deal rarer than scholars tend to assume ..." (Art, 133). Additionally, what may be seen as incongruities with deconstructive potential may not have been problems for the biblical narrator since "the Hebrew writer may have known what he was doing, but we do not" (Art, 136). We, however, are able to discern the difference between linear logic and narrative logic. In referencing the two instances of Joseph's 
Alter takes issue with source critics who believe that features like repetition reveal the biblical narrator's lack of skill. Alter references source criticism's inability to appropriately account for repetition in Gen 45:3-4 as an example. When Joseph reveals himself to his brothers, he twice states, "I am Joseph your brother." Rather than seeing the narrative effect of these words, source critics posit multiple antecedents, leading Alter to disapprove of source criticism "attributing to a duplication of sources this brilliantly effective repetition so obviously justified by the dramatic and psychological situation."63 Alter believes that source critics often ignore narrative artistry in favor of less compelling explanations.

According to Alter, historical critics work from a methodology that states, "the more atomistic, the more scientific." He reshapes their argument by declaring that "the atoms were often purposely assembled by the writers into intricate, integrated structures, which are ... what we experience as readers and which abundantly deserve scholarly consideration. ${ }^{\text {64 }}$ These so-called atoms served as the materials which the artists placed in a new medium by "establishing a careful context" for the pieces in order to give them "a new meaning. $" 65$

\footnotetext{
brothers receiving money in their bags, Alter believes that "in linear logic the same action could not have occurred twice in two different ways; but in the narrative logic with which the writer worked, it made sense to incorporate both versions available to him because together they brought forth mutually complementary implications of the narrated event, thus enabling him to give a complete imaginative account of it" (Art, 138).

${ }^{63}$ Alter, The Art of Biblical Narrative, 175. Adele Berlin also comments on the problems with source criticism and the Joseph story in Poetics and Interpretation of Biblical Narrative (BLS 9; Sheffield: Almond, 1983; repr., Winona Lake, Ind.: Eisenbrauns, 1994), 121.

${ }^{64}$ Alter, The World of Biblical Literature, 109.

${ }^{65}$ Alter, The World of Biblical Literature, 16.
} 
This literary art invites comparison to a mosaic which utilizes various pieces of disparate materials, places them together in a new way, and creates a beautiful picture. Alter himself only sparingly uses the word "mosaic" in his writing such as when he discusses whether or not Genesis 26 is a “'mosaic' of Isaac traditions or an integral literary unity." ${ }^{, 66}$ Alter shows that the term "mosaic" fails to reflect the high level of literary artistry and unity he sees in the biblical narrative. When writing about Hebrew literature, he offers a general description of Haskalah poetry as "a lifeless mosaic of biblical phrases," referring to something cobbled together rather than artistically woven such as a cento which consists of quotations from various authors. ${ }^{67}$ However, Alter refers to the biblical text by the word "arabesque," a word similar to "mosaic," when speaking of the narrators" "dazzling virtuosity in their arabesques of sound play and syntax, wordplay and image." 68 Whatever their connotations, "mosaic" and "arabesque" allow narrative critics to challenge up close views of the text that prevent one from seeing the complete picture. ${ }^{69}$

\footnotetext{
${ }^{66}$ Robert Alter, Genesis: Translation and Commentary (New York: W. W. Norton, 1996), 131.

${ }^{67}$ Robert Alter, ed., Modern Hebrew Literature (Library of Jewish Studies; New York: Behrman, 1975), 8. Perhaps he also chooses to avoid the term because the word "mosaic" is often used to refer to Moses and his alleged authorship of the Pentateuch.

${ }^{68}$ Alter, The World of Biblical Literature, 54-55.

${ }^{69}$ Narrative Criticism and its scholarly partners also represent a mosaic. In The Biblical Mosaic (1982), Robert M. Polzin and Eugene Rothman propose to examine the biblical text from a variety of multidisciplinary angles and ask literary questions. They wonder, "What would happen if . . . the elderly historian and the infant literary critics - were to view their understanding of specific biblical texts in the light of traditional exegesis developed by the learned rabbis of ancient times." (Robert M. Polzin and Eugene Rothman, eds., The Biblical Mosaic: Changing Perspectives [SemeiaSt; Philadelphia, Pa.: Fortress; Chico, Ca.: Scholars, 1982], 3).
} 


\section{A Literary Middleground}

To view this picture, Alter proposes a literary middle ground between the

"science" of historical criticism and methods driven to protect the truth of scripture:

The first several waves of modern biblical criticism, beginning in the nineteenth century, were from one point of view, a sustained assault on the supposedly unitary character of the Bible, an attempt to break it up into as many pieces as possible, then to link those pieces to their original life contexts, thus rescuing for history a body of texts that religious tradition had enshrined in timelessness, beyond precise historical considerations ... At the same time, the potent residue of the older belief in the Bible as the revelation of ultimate truth is perceptible in the tendency of scholars to ask questions about the biblical view of man, the biblical notion of the soul, the biblical vision of eschatology, while for the most part neglecting phenomena like character, motive, and narrative design as unbefitting for the study of an essentially religious document. The fact that such a substantial proportion of academic biblical studies goes on in theological seminaries, both here and in Europe, institutionally reinforces this doubled-edge pursuit of analyzed fragments and larger views, with scarcely any literary middleground. ${ }^{70}$

Alter defines his methodology as the center between two radically different approachesboth which generally ignore literary imagination.

While Alter sees problems with historical critics ignoring the literary artistry in

the text, he also believes that the New Critics silenced the author. Commenting on Roland Barthes' "the death of the author," Alter reasons that this demise occurred because scholars like the New Critics "became accustomed to speak of 'the text' doing things rather than the writer., ${ }^{, 71}$ As a result, the narrator largely remained hidden. ${ }^{72}$

\footnotetext{
${ }^{70}$ Alter, The Art of Biblical Narrative, 16-17. Alter's literary middleground categorizes the Bible as prose fiction, and Alter declares that "history is far more intimately related to fiction than we have been accustomed to assume" (Alter, Art, 24). Therefore Alter runs the risk of offending those on each side of this literary middleground. For further discussion of the Bible as sacred literature, see Alter, Art, 23.

${ }^{71}$ Alter, The World of Biblical Literature, 165. See Roland Barthes, "The Death of the Author" in Image, Music, Text. (Essays selected and translated by Stephen D. Heath; New York: Hill and Wang, 1977. For a defense of New Criticism, see René Wellek's Concepts of Criticism (ed. Stephen G. Nichols, Jr.; New Haven: Yale University Press, 1963), 7.
} 
Reader- Oriented Approaches and the Literary Imagination

In spite of Alter's attempts to bring the views of the narrator into focus, critics have charged him with failing to give reader-oriented approaches a place in the discussion. Gunn disapproves of Alter and Kermode's The Literary Guide to the Bible, arguing that the book fails to sufficiently address the concerns of feminist criticism. ${ }^{73}$ Alter does not completely ignore these issues; he simply chooses to look at them through the lenses of narrative economy and literary imagination rather than feminist criticism. Narrative economy and not merely the maleness of the majority of the narrators may have prevented issues important to women from arising in the text. While Alter could simply point to narrative terseness to answer to his critics, he shows that the literary imagination of the narrators also informed their choices: "My examples involve the power or plight of women in what is generally presumed, with good warrant, to be a set of narratives dominated by men. These instances seem to me especially instructive because they show the literary imagination — perhaps inadvertently — testing the limits of biblical ideology."74 The literary imagination gives rise to powerful female characters such as

For articles on studies in narrative criticism and the relationship between the text and the reader, see G. J. Brooke and J. D. Kaestli, eds., La narrativité dans la bible et les texts apparentés (BETL 149; LeuvenLouvain: Leuven University Press, 2000).

${ }^{72}$ For a discussion of various types of narrators and the ways in which they manifest their presence in the text, see Gérard Genette, Figures of Literary Discourse III (trans. Alan Sheridan; European Perspectives; New York: Columbia University Press, 1982), 245-59.

${ }^{73}$ Gunn, "Narrative Criticism," 206-07. See Robert Alter and Frank Kermode, eds., The Literary Guide to the Bible (Cambridge, Mass.: Belknap Press of Harvard University Press, 1987). See also Alter, Art, $\mathrm{x}$ for his views on "new narratology."

${ }^{74}$ Alter, The World of Biblical Literature, 44. For more on Alter's view of women in the text, see The Art of Biblical Narrative, 146. 
Hagar who names God, Rebekah, and not Isaac, hears from God about her sons, and Jael who brings victory to Israel.

Alter further challenges assumptions about the elite, male, literate priests who wrote the text by stating, "the literary art they exercised so splendidly was not always, or not entirely, subservient to religious ends." 75 Many scholars focus so intensely on the religious ideology behind the text that they ignore literary imagination. ${ }^{76}$

Alter also connects narrative artistry and literary imagination to its influence on the audience, noting that "art is after all made for an audience, not just for the effect."77 Artistically, the Bible is a "collage"; but the text can also be seen as "a kind of colloquy - the author speaking, the reader thinking back — between him and us."78 This colloquy invites responses from readers; however, in the quest to give readers a voice, scholars must not ignore the voice of the narrator - no matter how subtle it may be.

Biblical narrators did not intrude in the text by giving self-narratives like the prophets or by revealing their identities like modern writers. Alter claims that as a result of "the anonymity and the collective viewpoint of biblical writing . . . no place is allowed for the self-promoting identity of the individual writer or for the ephemerality of merely

\footnotetext{
${ }^{75}$ Alter, The World of Biblical Literature, 34.

${ }^{76}$ In fact, Alter believes that one type of inspiration cannot be studied without the other: "The evidence of the texts suggests that the literary impulse in ancient Israel was quite as powerful as the religious impulse or, to put it more accurately, that the two were inextricable, so that in order to understand the latter, you have to take full account of the former" (The World of Biblical Literature, 56).

${ }^{77}$ Alter, The World of Biblical Literature, 11.

${ }^{78}$ Alter, The World of Biblical Literature, 2, 15.
} 
private experience. ${ }^{, 79}$ Even when they interfere in the text, the intrusion is often inconspicuous.

Alter's Example of Narrative Intrusion

Alter provides an example of narrative intrusion in 1 Sam 10:9. He argues that the narrators have intruded in the text to better explain the character of Saul and the divine impetus behind his kingship: "Verse 9 [of I Sam 10] in which 'God gave him another heart' before the encounter with the prophets looks suspiciously like an editorial intervention, perhaps an attempt to compensate for the lack of reference to spiritual transformation in the language of the etiological tale proper." ${ }^{\prime 80}$ This comment may break the frame of the story that is built around Samuel's prophetic signs and their fulfillment since the story could continue without it. However, I would not classify the verse as an obtrusion since 1 Sam 10:6 has already stated that God will make Saul another man. Verse 9 reiterates this information. Therefore readers are less likely to question Saul's spiritual transformation because they rely on the omniscient perspective of the narrator.

Both Alter and Meir Sternberg have recognized the narrative art display by the biblical narrators as they emulate divine power through the use of omniscience. Alter describes this monotheistic revolution as "a distinctive poetics of biblical narrative fashioned for the special ends of the Bible's new monotheistic understanding of history and human nature." 81 Such an understanding works well with a study on the

\footnotetext{
${ }^{79}$ Alter, The World of Biblical Literature, 46.

${ }^{80}$ Alter, The World of Biblical Literature, 14.

${ }^{81}$ Alter, The World of Biblical Literature, 27.
} 
Deuteronomistic History because it connects this monotheistic revolution to the belief in the one God, the one king, the one place of worship, and perhaps to the one book that united all of these themes. If the Deuteronomistic School was responsible for propagating the monotheistic revolution on a theological and political level, then examining this innovation in literary terms becomes even more important. Alter credits monotheism with making the prose narratives of the Hebrew Bible different from their ancient Near Eastern and Greek counterparts as well as biblical prophecy while calling attention to the Hebrew Bible's influence on modern Western literature. ${ }^{82}$

In connecting the Hebrew Bible to other literature, Alter fails to give sufficient consideration to the Bible's ancient Near Eastern (ANE) setting, perhaps due to his training in modern literature. ${ }^{83}$ Alter's lack of regard for these ANE foundations leads to problems in his categorization of the Bible, the culture of the biblical text, and the divine. In his review of The Art of Biblical Literature, Gösta Ahlström counters Alter's claim that the origins of prose fiction can be traced to the Hebrew Bible by citing the Egyptian "Tale of Sinuhe" from the nineteenth century B.C.E. as an example of prose fiction. ${ }^{84}$ Other ANE texts may also fit this description.

Alter's characterization of the Bible is also problematic because he attempts to differentiate between prose fiction and epic, calling the Hebrew Bible a "deliberate

\footnotetext{
${ }^{82}$ Alter, The World of Biblical Literature, 157.

${ }^{83}$ I address the issue of omniscience and obtrusiveness in ANE literature in chapter 5.

${ }^{84}$ Gösta Ahlström, "Aspects of the Bible as Literature" (review of Robert Alter, The Art of Biblical Narrative), JR 64 (Oct 1984): 520-29.
} 
avoidance of epic." ${ }^{85}$ Susan Niditch, however, follows Sigmund Mowinckel in characterizing the text as "a collection or collections of national epic material." 86 The term "epic" fits the Hebrew Bible because the deity is often the protagonist of the story, and both the divine warrior and human warriors are heroes in Israelite epic. ${ }^{87}$

Alter prefers type scenes to epic scenes and focuses on the conventions of literature. According to Ahlström, some of his interpretations could be improved by "better knowledge of ancient Near Eastern customs." ${ }^{, 8}$ Coupling the type scenes of Alter with an understanding of customs from historical critics could help fill in some gaps for the reader.

Problems also arise in Alter's characterization of the divine. He describes the Hebrew deity as monotheistic and indeterminate, "an omnipotent God beyond all human manipulation. ${ }^{, 89}$ In contrast, the deities in ANE Literature and Homer are pagan and mechanistic, allowing humans and other gods to manipulate them. Alter's view of the Hebrew God fails to consider the aspect of covenant. The Hebrew deity is checked by the covenants and promises that exist between the divine and humans. Even in the face of a desire to eradicate the Israelites and begin anew with Moses, God becomes concerned about what the other nations will say (Ex 14:12-21). God, therefore, is bound to the

\footnotetext{
${ }^{85}$ Alter, The Art of Biblical Narrative, 25.

${ }^{86}$ Susan Niditch, “The Challenge of Israelite Epic," in A Companion to Ancient Epic (ed. James M. Foley; Blackwell Companions to the Ancient World; Malden, Mass.; Oxford: Blackwell, 2005), 277-87. See also Sigmund Mowinckel, "Hat es ein israelitisches Nationalepos gegeben?” ZAW 53 (1935): 130-52.

${ }^{87}$ Niditch, "The Challenge," 286.

${ }^{88}$ Ahlström, “Aspects,” 525.

${ }^{89}$ Alter, The Art of Biblical Narrative, 107.
} 
covenant because God could not destroy every one. God listens to the appeal of Moses and even allows Moses to define him as merciful. In a similar way, the biblical narrators act obtrusively in order to exonerate God and make the deity seem merciful even in the act of asking Abraham to sacrifice Isaac. ${ }^{90}$

\section{Other Narrative Critics ${ }^{91}$}

\section{Meir Sternberg}

Meir Sternberg also reveals that the most significant problem among many narrative critics is ignoring the ANE background of the Bible, and he attempts to bridge this gap by discussing the difference between paganism and monotheism. Omnipotence cannot exist in a pagan system because the chief god of the pantheon lacks complete control over the universe and "even at the best of times, he may have to bow to superior forces like fate." 92 Although the will of the Hebrew God is not affected by competing deities as in a polytheistic system, covenants and promises can inhibit divine action. Monotheism replaces the idea of fate with the concept that everything that happens is "of the Lord." An examination of the literary features of the Bible reveals that this “ideological thrust accounts for various distinctive regularities of composition and

\footnotetext{
${ }^{90} \mathrm{I}$ address this issue more fully in chapter 2.

${ }^{91}$ For articles by various narrative critics exploring similarities and differences within their field, see Jason P. Rosenblatt and Joseph C. Sitterson, Jr., eds., "Not in Heaven": Coherence and Complexity in Biblical Narrative (IndStBibLit ; Bloomington: Indiana University Press, 1991). For more on various books on biblical narrative, see Claus Westermann, Erzählungen in den Schriften des Alten Testaments (AzTh 86; Stuggart: Calwer, 1998), 43-58.

92 Even though Berlin's book on poetics (1983) preceded Sternberg's (1985), I have skipped ahead to Sternberg due to the connection between his and Alter's views on the monotheistic revolution (102).
} 
narration ... in terms of the rhetoric of omnipotence. ${ }^{93}$ This monotheistic worldview assumes that God is the cause of all things - whether good or bad. Therefore the narrator could easily use God to explain away a situation in an obtrusion.

Furthermore, the Hebrew Bible characterizes the divine as one who wishes to "impress his almightiness on humanity," revealing an explicit connection between God's omnipotence and God's desire to be known among the Israelites and other nations in the Hebrew Bible. ${ }^{94}$ Sternberg cites several passages which show the divine concern for the knowledge other nations have about God's power (Num 14:16) and the Israelites' ability to connect displays of God's omnipotence with the knowledge that God is the Lord (Ex $14: 4 ; 16: 12)$. In fact, God wants to avoid the situation that results in Judges when the people neither know the Lord nor what the Lord has done for Israel (Judg 2:7) ${ }^{95}$ Sternberg offers the following conclusion: "The ubiquitous causal link of God's wonderworking and man's knowledge goes to the heart of the biblical world view. In particular, Israel's fortunes throughout history depend on her observance or loosening of that bond. ${ }^{96}$ This connection between omnipotence and the spread of this knowledge leads Sternberg to further explore the concept of omniscience.

In thinking about the omniscient narrator and the omniscient God, Sternberg asks, "Is it ... that the narrator assumes omniscience because he could not otherwise do justice to an infallible God and impress on the reader, by appropriate suppressions, his own

\footnotetext{
${ }^{93}$ Sternberg, The Poetics of Biblical Narrative, 102.

${ }^{94}$ Sternberg, The Poetics of Biblical Narrative, 102.

${ }^{95}$ Sternberg, The Poetics of Biblical Narrative, 102.

${ }^{96}$ Sternberg, The Poetics of Biblical Narrative, 102.
} 
fallibility? Since the Omniscient inspires his prophets, moreover, does the narrator implicitly appeal to the gift of prophecy, so as to speak with redoubled authority as divine historian?" ${ }^{97}$ The potential connection between prophecy and this particular type of history is strengthened by considering that the narratives of Joshua-Kings have the designations, Deuteronomistic History and the Former Prophets. This link between history, prophecy, and narrative may overshadow some of the differences between selfpromoting prophets and the self-effacing narrators. For example, although prophetic utterances are placed in the context of what will happen in the future and narration reports on what has already happened, narrative is similar to prophecy because of foreshadowing. Foreshadowing creates a prophecy fulfillment scheme in biblical narratives, reinforcing the credibility of the Deuteronomistic School by defining them as true prophets.

The connection between omniscience in narrative and prophecy allows Sternberg to propose that omniscient narrative developed early in the history of Israel. Assigning a later date to the first person narratives of Ezra and Nehemiah, he sees the omniscient monotheistic narrator as representative of an earlier development. However, he neglects to consider the Bible's ANE background since omniscience appears in texts such as the Gilgamesh Epic (OB).

Although he brings some of the concerns of ANE literature to the discussion and ignores others, Sternberg better defines the relationship between historical criticism and narrative criticism. Sternberg criticizes literary approaches because they "react

\footnotetext{
${ }^{97}$ Sternberg, The Poetics of Biblical Narrative, 12.
} 
against ... [the] atomism [of historical criticism] by going to the opposite extreme of holism."98 Therefore a combination of literary and historical approaches has the potential to create a more balanced methodology.

Sternberg also offers helpful insights into the gaps created by the narrator. The narrator's skill or lack thereof in negotiating these gaps has a tremendous effect on reader response. In some instances, the narrator fills in a gap by obtruding. At other times, readers may wonder why the narrator allowed a gap to remain in the narrative. Additionally, Sternberg's discussion of chronology as a way of creating frames for stories opens the door for considering the various ways that the biblical narrators produce a frame, order a frame, and break a frame. His study of gaps and framing create a strong foundation for forming a methodology to study obtrusiveness.

Adele Berlin

Adele Berlin hopes to bring the biblical narrator back into the framework of biblical scholarship. Although she recognizes that scholars should respect the goals of diverse methodologies, she wants to prevent the narrator from fading into the shadows when scholars prefer the text or the reader over the narrator. As Berlin writes in Poetics and Interpretation of Biblical Narrative (1983), scholars must avoid committing "the sin of New Criticism" by "closing off the world of the text from the real world." 99 In the real world, readers and authors interact with each other in the text.

Like Sternberg, Berlin sees more compatibility in these approaches than the history of interpretation has led many to believe: "Synchronic poetics of biblical narrative

\footnotetext{
${ }^{98}$ Sternberg, The Poetics of Biblical Narrative, 13.

${ }^{99}$ Berlin, Poetics and Interpretation, 16.
} 
can ... prevent historical-criticism from mistaking as proof of earlier sources those features which can be better explained as compositional or rhetorical features of the present text."100 Berlin gives narrative and historical critics good reason to dialogue.

As a component of historical criticism, redaction criticism may reveal the narrative artistry displayed in constructing the text. Once the narrators wove sources together, they placed frames around the story and comments within the frames, allowing readers to discern their reasons for writing. Berlin observes that narrators "may step out of the frame of the story ideologically as well as temporally, as the deuteronomic narrator frequently does." ${ }^{101}$ Although various intrusions offer narrative information about history, geography, and etiology, ideological intrusions reveal more about the author's purpose for recording a particular story.

\section{Berlin's Example of Narrative Obtrusiveness}

An example of narrative obtrusiveness is brought out in Berlin's discussion of I

Kings 12:15. According to the Deuteronomist, Rehoboam's failure to listen to the people was "by reason of the Lord" in order to bring the prophecy of Ahijah the Shilonite to fulfillment. ${ }^{102}$ While readers might assume that the king merely preferred the advice of his contemporaries to the counsel of the elders, the narrator wants the reader to know that God had a hand in these events. This passage reveals the way in which the

\footnotetext{
${ }^{100}$ Berlin, Poetics and Interpretation, 112. Berlin points to the compositional history of Gilgamesh as an example, stating that this epic "was not the result of the kind of cut and paste operation that source critics describe, nor was it the product of a slow, natural accretion of materials, as form critics assume" (132).

${ }^{101}$ Berlin, Poetics and Interpretation, 59.

${ }^{102}$ Berlin, Poetics and Interpretation, 59.
} 
Deuteronomistic narrator frames the story and offers commentary, utilizing divine causality to ascribe the actions of a human to the plan of God-a common use of obtrusiveness within the Deuteronomistic History.

Berlin, however, focuses more on narrative economy than obtrusiveness. She also offers a particularly poignant comment on the undernarrated Bathsheba: "One and a half cold, terse verses to sum up the condition of a woman who has had an adulterous affair, become pregnant, lost her husband, married her lover, the king of Israel, and borne his child!"103 The narrator fails to fully form the character of Bathsheba, leaving many gaps open in her story. Although narrative economy and artistry somewhat explain this omission, modern readers often find missing elements in the stories of female characters disturbing.

This tendency toward "minimizing intrusion by the narrator" is selective representation, which allows the author to summarize scenes and even omit various details. ${ }^{104}$ In many biblical narratives, such as in the book of Ruth, the narrator tends to "limit his point of view and have the evaluations made by the characters." "105 Dialogue provides a great deal of information, allowing readers to fill in gaps for themselves or wonder why the narrator chose not to offer more commentary. In addition to dialogue,

\footnotetext{
${ }^{103}$ Berlin, Poetics and Interpretation, 26.

${ }^{104}$ Berlin, Poetics and Interpretation, 79, 97.

${ }^{105}$ Berlin, Poetics and Interpretation, 98.
} 
perhaps the narrator sets up the story to reach an intended end; and this structure aids reader understanding. ${ }^{106}$

\section{Shimeon Bar-Efrat}

Shimeon Bar-Efrat characterizes the narrator as one of the "structural components" of a story in Narrative Art in the Bible (1989), concluding that "the character of the narrators and the way in which they mediate is of supreme importance." 107 The portrait painted by scholars has revealed generally laconic narrators, relying on dialogue to convey information, and using narrative economy to craft their art. ${ }^{108}$ Those instances where the narrators act out of character present a different view of these artists.

In general, biblical narrative differs from other forms of biblical literature because Bar-Efrat notes that "prophetic and Wisdom literature express their views directly, openly urging that they be accepted, [and] the narrative operates in an oblique and unobtrusive

\footnotetext{
${ }^{106}$ Jurij Lotman notes that more structured texts favor the reader due the minimal effort required to understand the text. Such texts include "folklore, medieval art, picaresque novels, Romantic narrative poems" (The Structure of the Artistic Text [trans. from the Russian by Gail Lenhoff and Ronald Vroon; Michigan Slavic Contributions 7; Ann Arbor: University of Michigan, 1997], 295-96).

${ }^{107}$ Shimeon Bar-Efrat, Narrative Art in the Bible (trans. Dorothea Shefer-Vanson in conjunction with the author; BLS 17; JSOTSup 70; Sheffield: Almond, 1989), 13-14.

${ }^{108}$ Meir Weiss notes that the narrator is not only laconic; but even when the narrator's voice appears, the narrator takes on the perspective of the characters through a state somewhere between direct and indirect speech. Some examples include the narrator adopting the perspective of Jacob to recognize "it was Leah" Jacob had married instead of Rachel (Gen 29:25); the connection between Joseph and Egypt that the sons of Jacob realize as they head down to Egypt to buy grain and think of themselves as "Joseph's brothers" (Gen 42:3); Jonah's motivation for going to Tarshish (Jon 1:3). The perspective of the narrator changes based on which based character the narrator writes about as in Gen 21:9-11 when the narrator calls Ishmael the son of Hagar the Egyptian from Sarah's perspective while Abraham views him as his son. ("Einiges über die Bauformen des Erzählens in der Bibel," VT 13 [1963]: 456-75). I revisit this issue more fully in chapter 5 .
} 
way." ${ }^{, 109}$ When the narrator steps out of the shadows, more details of narrative identity come to light since "the narrator is also revealed in those passages which contain an explanation or comment about what is happening rather than an account of a specific event ... Explanations of events are a powerful tool in the hands of the narrator, enabling clear and unequivocal messages to be conveyed to readers." ${ }^{110}$ At face value these messages may seem clear, especially in the context of the Deuteronomistic History; but additional difficulties may arise for readers. If a normally laconic narrator intrudes in the text, then scholars cannot assume that these comments will be easily interpreted. They may open up multiple interpretative avenues by going against the grain of the narrator's usual modus operandi. Perhaps the narrator behaves differently because the narrator fears giving up control to the reader and risking the possibility that the reader will misunderstand the narrator's intentions. Therefore narrative obtrusions are the narrator's reaction to potential questions or problems created by the reader as I will show in my next chapter.

According to Bar-Efrat, obtrusions may diminish narrative art because "a large number of interventions by the narrator mar the illusion of reality in the narrative, diverting attention from the events of the narrative to the craft of narration .... The narrative will be more vivid, dramatic, gripping and realistic the less the narrator's existence is felt." ${ }^{111}$ Obtrusions risk breaking the bond between economy and artistry.

\footnotetext{
${ }^{109}$ Bar-Efrat, Narrative Art, 16. Note the difference between the didactic functions of these texts and narrative.

${ }^{110}$ Bar-Efrat, Narrative Art, 26.

${ }^{111}$ Bar-Efrat, Narrative Art, 32.
} 
However, they also have the potential to form a greater bond between the reader and the narrator by creating a more open conversation in which the narrator engages the reader more directly.

Robert Polzin and the Deuteronomistic History

In his literary study of the Deuteronomistic History, Robert Polzin sees a "high degree of artistic composition" in the work. He criticizes scholars like Noth who have noticed this artistry, but "have ignored many of the features of the History that account for its proper place in the treasury of world literature." ${ }^{\prime 12}$ Polzin sees the artistry within the text but chooses not to make a major distinction between author and redactor because it would diminish narrative art. ${ }^{113}$ He focuses more on "authorial intention . . . than redactional intrusion," calling the ideological perspective of the narrator "the most important aspect of the narrator's voice." 114

Although some comments seem like helpful asides that give the reader information for understanding the story, they may actually reveal the narrator attempting to coerce the reader into a particular point of view. Citing 1 Sam 9:9 in which the narrator explains why people in Israel went to seers, Polzin notes that even this verse "forces the

\footnotetext{
${ }^{112}$ Robert Polzin, Samuel and the Deuteronomist: I Samuel $\left({ }^{\mathrm{st}}\right.$ ed.; A Literary Study of the Deuteronomistic History, part. 2; San Francisco: Harper \& Row, 1989), 11.

${ }^{113}$ Polzin, Samuel and the Deuteronomist, 6.

${ }^{114}$ Polzin, Samuel and the Deuteronomist, 40, 21. For a discussion of narrative intent, see Klaus Seybold, Poetik der erzählenden Literatur im Alten Testament (Poetlogische Studien zum Alten Testament 2; Stuttgart: Kohlhammer, 2006), 253-73.
} 
reader to attend focally to the narrator's words rather than those of the characters." Narrative asides contain this type of force, but obtrusions are even more powerful. Similar to Sternberg, Polzin thinks that the Former Prophets also possess their own prophetic gifts in narration. He characterizes the comment in 1 Sam 9:9 as "narrative postdiction" which is "prophetic prediction in reverse." He further argues that, "like the Israelite prophet's knowledge, the Israelite narrator's omniscience is always and everywhere constrained by the LORD's omnipotence." "16 The Lord governs both past and the future in prophecy. The narrator behaves like a prophet and "is the shaper rather than the maker of the plot."117 The narrator, however, exercises some amount of governance over the actions of God by ascribing certain situations to God in order to explain events. By intruding in a story through divine causality, the narrator influences the way the reader understands the story and, thereby, gains more control over the narrative.

\section{Summary}

After examining the relationship between narrative criticism and other exegetical methods, I have reached several conclusions:

(1) Narrative economy and unity make the biblical text art;

(2) The idea of narrative unity does not ignore sources or redactions but accounts for them through artistic weaving, challenging both historical criticism and deconstruction.

(3) The biblical narrators are normally laconic, but they may sometimes expand their role within the text;

\footnotetext{
${ }^{115}$ Polzin, Samuel and the Deuteronomist, 96.

${ }^{116}$ Polzin, Samuel and the Deuteronomist, 96-7.

${ }^{117}$ Polzin, Samuel and the Deuteronomist, 96-7.
} 
(4) Narrative obtrusions have the ability to diminish or call into question narrative artistry; they may also provide a lot of information about the narrator's control over the text; these obtrusions assist readers in learning about the narrator's worldview, but they differ from historical criticism's search for the historical origins of the author;

(5) These obtrusions explicitly attempt to influence reader response;

(6) Methods which may seem incompatible with narrative criticism, in particular redaction criticism and reader response, may assist narrative criticism in forming a methodology to better understand these obtrusions and their effects on the reader. 


\section{CHAPTER II}

\section{OMNISCIENCE AND OBTRUSIVENESS}

"the artist should be in his work like God in his creation, invisible and omnipotent, so that one can feel him everywhere, but one cannot see him"

Letter to Mlle Leroyer de Chantapie, March 18, $1857^{118}$

The previous chapter discussed the various methodologies that contributed to the formation of narrative criticism, the possibility of using redaction criticism for literary purposes rather than historical ones, and the potential alliance between narrative criticism and reader response in studying narrative obtrusiveness. In this chapter, I formulate a methodology for determining obtrusiveness. This methodology faces several challenges, including narrative criticism's lack of a clearly defined system for interpretation, the difficulty of combining historical critical methods in literary concerns, and the inconsistent manner in which the biblical narrators employ obtrusiveness. In spite of these difficulties, I argue that obtrusions can be identified by distinguishing omniscience from obtrusiveness and by determining the essentiality and location of a narrative comment. I round out this methodology by considering the effect of deleting the comment and by examining commentary on potential obtrusions from reception history. In forming this methodology, I readily admit that determining some obtrusions may depend on choices scholars make in translation and interpretation.

${ }^{118}$ Angelo Marchese, L'officina del racconto. Semiotica della narratività (Milano: Mondadori, 1983), 146. 


\section{Methodology}

Because obtrusiveness begins with omniscience, my methodology distinguishes between these terms. While every obtrusion naturally relies on the omniscient perspective of the narrator, every omniscient comment is not an obtrusion. Most omniscient comments convey necessary information to the reader. Alter's contrast of "absolutely essential action" with "obtrusive elaboration or any obvious intervention by the narrator," shows that obtrusions provide additional — but not necessary indispensable - information to a story. ${ }^{119}$ Therefore this methodology explores the potential effect on reader response that could result from deleting a narrative obtrusion. The location of a narrative comment also proves key in determining obtrusiveness, especially if such a statement reveals a noticeable intervention by the narrator that attempts to preempt potential reader questions or assumptions.

Since gaps represent areas where the narrator chose not to insert an aside or an obtrusion, this methodology contrasts the two. In some instances, the narrator fills in potential gaps with obtrusions; but at other times, the narrator leaves gaps in the text. Perhaps some gaps remained because the narrator did not foresee the reader's implied questions or assumptions, or because the narrator simply chose not to deal with such issues.

In comments that appear obtrusive, reception history proves valuable to my methodology. By presenting a historical account of various reader responses to the biblical text, reception history often helps delineate between general omniscience and

${ }^{119}$ Alter, The Art of Biblical Narrative, 184. 
obtrusiveness. Later interpreters who intrude in a text in order to explain a difficult narrative situation highlight the initial problem confronted by the narrator. Some scholars may even discover more subtle obtrusions that might go undetected in this methodology. In spite of the evidence from narrative criticism and reception history, whether or not an omniscient comment represents an obtrusion often depends on the choices of the interpreter/translator.

Those instances where the narrator explains the activities of God or invokes the divine to explain a situation increase the probability that an obtrusion has taken place. With its focus on the actions of the divine, Gen 22:1 provides a nice opportunity to test my methodology and to discuss the factors that motivated the narrator to surpass the boundaries of omniscience.

\section{Methodological Difficulties}

I have wrestled with several obstacles in constructing a methodology to identify obtrusions. Chief among them is the difficulty of creating an approach to address the narrator's atypical actions, especially when other literary studies provide few methodological models. Additionally, the use of redaction criticism for literary purposes rather than historical ones demands further discussion since it reveals the tension between historical criticism and narrative criticism. 


\section{Issues in Literary Studies}

Alter reveals the pitfalls and promises involved in creating a method to determine obtrusiveness. He describes the narrator's 'general refusal to comment or explain what he reports" as "purposely selective." 120 Therefore in seeking to determine why a narrator acts out of character by intruding in a scene, Alter raises a number of questions:

Why at a particular juncture does the narrator ... jump forward to the time of his contemporary audience and explain that in those days it was the custom in Israel to perform such and such a practice? Why does he pause to make a summarizing statement about the condition of a character, as, for example, in the observation about Joseph's already established viceregal status just as the ten brothers arrive in Egypt? Why at certain points is the regular rapid tempo of narration slowed down to take in details of a kind for which in general no time is allowed? ${ }^{121}$

Questions such as these drive my methodology. However, difficulties arise in forming a systemic plan to answer these queries, especially considering Alter's recognition of the complications involved in studying obtrusions: "these various relaxations or reticence are, I suspect, the operation of biblical narrative most resistant to a manageable rule of thumb, but an alertness to their occurrence and a willingness to wonder about their motivation, with the specific contexts as a guide, will help make us better readers of the biblical tales." ${ }^{122}$ Even as Alter stresses the difficulty of dealing with obtrusions, he reveals the potential fruitfulness of a methodological alliance between narrative criticism and reader response.

In spite of this promise, narrative scholarship has not always provided good methodological examples. Alter praises Auerbach's work, but he recognizes its lack of

\footnotetext{
${ }^{120}$ Alter, The Art of Biblical Narrative, 21.

${ }^{121}$ Alter, The Art of Biblical Narrative 184-85. See also p. 21.

${ }^{122}$ Alter, The Art of Biblical Narrative, 184-85.
} 
systematization: "Auerbach must be credited with showing more clearly than anyone before him how the cryptic conciseness of biblical narrative is a reflection of profound art, not primitiveness, but his insight is the result of penetrating critical intuition unsupported by any real method for dealing with the specific characteristics of biblical literary forms. ${ }^{" 123}$ And while Alter finds Auerbach's discussion of the binding of Isaac insightful, he wonders if his analysis would work on more intricate stories such as David, Job, and Esther. ${ }^{124}$

Alter has similar issues with Good's Irony in the Old Testament, noting that the book "has no clearly defined critical method, no way of adequately discriminating the complex distinctive forms of biblical literary art." ${ }^{125}$ Nevertheless he observes that many studies of irony lack methodology, revealing a potential problem in any literary studyno matter the text. Therefore this work exceeds some previous literary studies simply by creating a methodology.

Redaction Criticism: Literary and Historical Issues

Examining potential redactions through the lens of narrative criticism may create problems, especially since similar efforts in the past have garnered mixed reactions. Moore believes that narrative criticism should function as "a congenial helpmate to redaction. ${ }^{, 126}$ In contrast, Gunn argues that scholars have yet to fully explicate the relationship between historical and narrative criticism and calls for "a more sophisticated

\footnotetext{
${ }^{123}$ Alter, The Art of Biblical Narrative, 17.

${ }^{124}$ Alter, The Art of Biblical Narrative, 17.

${ }^{125}$ Alter, The Art of Biblical Narrative, 15.

${ }^{126}$ Moore, Literary Criticism and the Gospels, 57.
} 
discussion than it has generally been afforded so far." 127 He also points out that "few scholars in practice have demonstrated an ability to afford literary and historical criticism equally serious consideration in any sustained study of biblical narrative." ${ }^{128}$ Eslinger proposes a potential solution: "only through methodological engagement will the weaknesses of each position be exposed and corrected and only then should the desired rapprochement occur." 129 The problems involved in putting these methodologies in conversation highlight their distinctive viewpoints.

In the eyes of many historical critics, narrative obtrusions either become simple footnotes or redactions. Their value lies in their ability to serve as windows into the historical world rather than as signposts in the literary world. Therefore historical criticism and narrative criticism define the worth of redaction criticism based on different methodological presuppositions. Still, the two methods may have something to offer each other with the understanding that narrative criticism may view historical criticism as a secondary recourse and vice versa. ${ }^{130}$

Historical criticism assists narrative critics in "understanding certain features of a text and avoiding misinterpretation."131 Perhaps historical criticism fills in gaps that the

\footnotetext{
${ }^{127}$ Gunn, "Narrative Criticism," 228.

${ }^{128}$ Gunn, "Narrative Criticism," 228.

${ }^{129}$ Lyle M. Eslinger, Into the Hands of the Living God (JSOTSup 84; BLS 24; Sheffield: Almond, 1989), 910 .

${ }^{130}$ In contrast to many American scholars, French scholar Daniel Marguerat argues that historical and narrative criticism can and should be studied together because the former provides a context for the latter ("Entrer dans le monde du récit," in Quand la Bible se raconte [ed. Daniel Marguerat; Lire la Bible 134; Paris: Cerf, 2003], 9-37).

${ }^{131}$ Bowman, "Narrative Criticism, 19.
} 
laconic narrator either chose not to mention or felt needed no explanation because the narrator assumed the audience already knew such information. In this way, historical criticism gives narrative critics a better understanding of the conventions of the biblical world.

Narrative criticism aids historical critics by uncovering the literary reality constructed by the biblical narrators. Some historical critics may find this reality counter to their goal of reconstructing the past, especially since they question the historical sensibilities of the narrators; however, narrative comments may offer potential clues to a narrator's place in history. Although locating the historical setting of the narrator exceeds the scope of this study, some historical critics may find value in studying narrative obtrusions for historical purposes rather than literary ones.

In spite of the many challenges noted, this methodology has great promise because it represents the pioneering spirit of new literary criticism. As Clines and Exum observe, "what biblical studies needs at this moment is not so much systematization as a spirit of exploration and methodological adventurousness, where every new way of looking at our familiar texts is to be seized upon and tested for all it is worth." ${ }^{132}$ This method for studying biblical narratives may also open up new avenues for considering obtrusiveness in ANE literature. ${ }^{133}$

\footnotetext{
${ }^{132}$ Clines and Exum, New Literary Criticism, 13.

${ }^{133}$ I explore obtrusions in ANE literature in chapter 5.
} 


\section{Obtrusiveness Begins with Omniscience}

I base my methodology on the argument that obtrusiveness begins with omniscience. Although occasionally commenting from an omniscient perspective, the narrator is rarely obtrusive. ${ }^{134}$ This general lack of obtrusiveness arises from a narrator "highly selective about sharing his omniscience with readers." ${ }^{135}$ For example, although the narrator will often disclose information as a part of a prophecy-fulfillment scenario, the narrator seldom uses omniscience as an anticipation to give readers information about the outcome of an event before the event has occurred. ${ }^{136}$ In most cases, the narrator completely withholds information or holds back on the amount of knowledge shared. This hesitation to share omniscient knowledge inhibits obtrusiveness. However, in those unusual instances where the narrator actively seeks to influence the response of the reader, omniscience becomes obtrusiveness.

The laconic and selective narrator acts out of character by crossing the threshold between omniscience and obtrusiveness. Although the omniscient perspective gives rise to obtrusiveness, Alter observes a significant link between the attributes of omniscience and inobtrusiveness:

\footnotetext{
${ }^{134}$ Alter suggests that one of the main ways in which the biblical narrator seems obtrusive is through the use of repetition since repetition challenges literary economy and seems "primitive" (The Art of Biblical Narrative, 88).

${ }^{135}$ Alter, The Art of Biblical Narrative, 158. For more on the selective nature of the narrator and the narrator's scope of knowledge, see Zecharia Kallai "The Explicit and Implicit in Biblical Narrative," in Congress Volume: Paris 1992 (VTSup 61; Leiden: E. J. Brill, 1995): 107-17.

${ }^{136}$ Bar-Efrat, Narrative Art, 179. Bar-Efrat notes that some exceptions to this rule occur in the Deuteronomistic History: Saul and Samuel no longer seeing each other (1 Sam 15:35), the preordained death of Eli's sons (1 Sam 2:25), and the failure of Ahithophel's advice (2 Sam 17:14). Anticipatory devices are also used to foreshadow an event. See also Nahum M. Sarna, "The Anticipatory Use of Information as a Literary Feature of the Genesis Narratives," in Studies in Biblical Interpretation (Philadelphia: JPS, 2000), 211-20.
} 
Perhaps the most distinctive feature of the role played by the narrator in the biblical tales is the way in which omniscience and inobtrusiveness are combined. The sweep of the biblical narrator's authoritative knowledge extends from the very beginnings of things, which he can report down to the precise language and order of the divine utterances that brought the world into being, to the characters' hidden thoughts and feelings, which he may summarize for us or render in detail as interior speech. He is all-knowing and also perfectly reliable: at times he may choose to make us wonder but he never misleads us. ${ }^{137}$

The combination of omniscience and inobtrusiveness reveals the command the narrator exercises over the text. Therefore obtrusions represent instances where the narrator desires to exercise greater control over the text, perhaps because the narrator worries about losing power or giving too much freedom to the reader. Alter believes that the narrator never misleads readers, but obtrusions show that the narrator leads readers away from certain questions.

Locating these intrusions, however, may prove difficult because of the narrator's laconic style. The fact that "Biblical narrative is laconic but by no means in a uniform or mechanical fashion" tests the limits of this methodology. ${ }^{138}$ In some cases, readers may be less aware of obtrusions. Since the generally unobtrusive narrator gains the reader's confidence through occasional displays of the omniscient perspective, some readers may pass over obtrusions without a second thought. In contrast, readers who notice obtrusions may find that these narrative interruptions create new questions.

\footnotetext{
${ }^{137}$ Alter, The Art of Biblical Narrative, 184.

${ }^{138}$ Alter, The Art of Biblical Narrative, 21.
} 


\section{Varying Levels of Intrusiveness}

One of the most recognizable types of narrative intrusion is called a break frame. In defining break frames, Jerome $\mathrm{T}$. Walsh contrasts two functions of the narrator: narrator as "storyteller" and narrator as "commentator."139 Acting as a storyteller, the narrator allows the events to unfold with minimal to no interference. When the narrator assumes the role of commentator, the narrator may break frame to provide essential information or influence reader response. The narrator's comments fall into different categories.

Sometimes the commentary merely offers historical explanations to the reader. Walsh's examples of break frames fit in this category. He cites Josh 7:26 (place name etiology) and 8:29 (origin of a heap of stones) as examples of instances where "the narrator will 'break frame' to relate some event he has just described to something contemporary to his audience." ${ }^{\prime 40}$ This commentary not only breaks the frame of the narrative, but breaks the time frame as well. These examples also fall under the category of general omniscience due to their minimal intrusiveness.

For the most part, the narrators of the Hebrew Bible do not utilize the full range of intrusiveness available to them because they rely on "neutral omniscience" in which "the narrative is allowed to speak for itself." ${ }^{141}$ In many cases, the narrator has no need to influence the reader with an obtrusion due to the inextricable link between the viewpoints

\footnotetext{
${ }^{139}$ Walsh, Style \& Structure, 125.

${ }^{140}$ Walsh, Style \& Structure, 125.

${ }^{141}$ Bar-Efrat, Narrative Art, 23-24.
} 
of the reader and narrator in which "the reader comes to see what the narrator sees." The collective vision shared by the narrator and the reader not only allows obtrusions to remain obscure but also limits the need for commentary. ${ }^{143}$

When the narrator interrupts the flow of the text, the narrator's comments range from "explanatory gloss" to "massive intrusion." According to Marguerat and Bourquin, "Either the narrator appeals directly to the reader, which amounts to a massive intrusion; in this case he brings about a temporal shift in relation to the story. Or the narrator limits himself to completing, by means of an explanatory gloss, information which is thought to be insufficient in itself." ${ }^{144}$ Figure 1 highlights various levels of intrusiveness.

\footnotetext{
${ }^{142}$ Berlin, Poetics, 52.

${ }^{143}$ I discuss the neutral omniscience employed by the Hurro-Hittites in chapter 5.

${ }^{144}$ Marguerat and Bourquin, How to Read Bible Stories, 102.
} 


\begin{tabular}{|c|c|c|}
\hline Type of Intrusion & Definition & Example \\
\hline $\begin{array}{l}\text { Explanatory Gloss } \\
\text { (Exposition) }\end{array}$ & $\begin{array}{c}\text { "a commentary by the narrator explaining } \\
\text { or qualifying an aspect or an action of the } \\
\text { story." }\end{array}$ & $\begin{array}{c}\text { "for maiden princesses [such as } \\
\text { Tamar] were customarily dressed } \\
\text { in such garments" (2 Sam13:18, } \\
\text { TNK). }{ }^{145}\end{array}$ \\
\hline $\begin{array}{l}\text { Explicit Commentary } \\
\text { (Editorial Omniscience) }\end{array}$ & $\begin{array}{l}\text { "an intervention by the narrator, whether } \\
\text { in a commentary on the story } \\
\text { (interpretation, explanation, judgment) or } \\
\text { in a direct communication to the narratee } \\
\text { (addressing the reader)" }\end{array}$ & $\begin{array}{l}\text { "Some time afterward, God put } \\
\text { Abraham to the test" } \\
\text { (explanation in Gen } 22: 1, \mathrm{TNK} \text { ). }\end{array}$ \\
\hline $\begin{array}{c}\text { Apostrophe } \\
\text { (Absent in HB } \\
\text { narrative; present in HB } \\
\text { poetry and the NT). }{ }^{146}\end{array}$ & $\begin{array}{l}\text { Type of explicit commentary which is } \\
\text { "the most direct form of intrusion by the } \\
\text { narrator." }\end{array}$ & $\begin{array}{l}\text { "But when you see the desolating } \\
\text { sacrilege set up where it ought not } \\
\text { to be (let the reader understand)," } \\
\text { (Mk 13:14, TNK; cf. Mt 24:15). }\end{array}$ \\
\hline
\end{tabular}

Figure 1. Ranges of Intrusiveness from Least Intrusive to Most Intrusive ${ }^{147}$

Figure 1 shows that the narrator of the Hebrew Bible never achieves the highest level of obtrusiveness because apostrophe only appears in biblical poetry and in the NT. And while many narrative remarks fall under the category of exposition in which omniscience never crosses over into obtrusiveness, explicit commentary shows the narrator working to influence reader response. ${ }^{148}$

\footnotetext{
${ }^{145}$ For other examples, see Gen 13:6 and 1 Sam 9:9. For a discussion of the word kî and omniscience, see Bar-Efrat, Narrative Art, 30. For a discussion of הנה, see Berlin (Poetics, 62), in which she notes that "Often a statement of perception includes the word hinneh (הנה), which is known sometimes to mark the perception of a character as distinct from that of the narrator."

${ }^{146}$ Alonso-Schökel notes that "apostrophe, suddenly directing the speech at someone, thereby interrupting the course of the exposition," is not found in biblical narrative; however, several examples can be found in biblical poetry (Is 49:12-13; Zech 2:7; Hab 2:20; Nah 2:9; Jer 12:9; Ps 6:8/9) (A Manual of Hebrew Poetics [Subsidia Biblica 11; Roma: Pontificio Istituto Biblico, 1988], 155).

${ }^{147}$ Quotations taken from Marguerat and Bourquin, How To Read Bible Stories, 102-03, 107.

${ }^{148}$ Glosses may also have greater significance than previous scholarship has recognized. For example, Gen 9:18, 22 calls Ham the father of Canaan. Although scholars have viewed this note as "a harmonizing gloss linking P and J materials," Sarna notes that Rashbam views it as "an original, characteristic feature of the narrator's literary technique (Sarna, "Anticipatory Use," 212). See Samuel Ben Meir, Rabbi Samuel ben Meir's Commentary on Genesis: An Annotated Translation (trans. Martin I. Lockshin; Jewish Studies 5; Lewiston, NY: E. Mellen, 1989).
} 
In some texts, the narrator may use character dialogues to guide the reader and, as a result, reduce opportunities for obtrusiveness. For example, Berlin contrasts external evaluations in Kings in which "the narrator may step out of his story and evaluate it for the audience" with embedded evaluations found in the dialogues of Ruth. ${ }^{149}$ While character speeches reveal narrative intent in Ruth, the narrator of Kings more forcefully intrudes to provide similar information. Therefore the level of obtrusiveness may decrease in proportion to the amount of dialogue in a story since the narrator may use characters to explain situations. ${ }^{150}$ In noting that dialogue includes "only the most minimal intervention of the narrator," Alter points to the narrator's propensity to address key events by using the direct speech of characters. ${ }^{151}$ Perhaps the narrator only obtrudes in significant situations and, in general, depends on dialogue and neutral omniscience to convey information.

\section{Narrative Information}

A look at three basic categories of narrative comments helps to determine whether the narrator displays general omniscience or behaves obtrusively when presenting information: a. Etiological/“Historical” Information: a reference to a time or place that

\footnotetext{
${ }^{149}$ Berlin, Poetics, 105. Berlin believes that "internal or embedded evaluation is more authentic and more dramatic than a narrator's comment." Her examples include Boaz 's description of Ruth's loyalty $(2: 11)$ and her status as a "worthy woman" (3:10-11).

${ }^{150}$ At times both a narrative comment and a character's statement are used to describe a particular point of view. (See Ex 3:2-4a and 14:4, 8). Regarding dialogue, Berlin writes, "It is not that the Bible is incapable of expressing thoughts without speech, but that by expressing in speech things that were never spoken aloud the Bible is able to maximize characterization and the presentation of multiple points of view" (Poetics, 66).

${ }^{151}$ Alter, The Art of Biblical Narrative, 182. I briefly address the way the narrator co-opts the voice of a character in chapter 4.
} 
adds an air of authenticity to a story or helps to explain an issue to readers; b. Character Information: the thought processes and motives of a character, the character's knowledge or lack thereof, and the emotional state of the character; c. Information about the Divine: elements of divine causality that reveal God as the impetus behind an act or an event.

These examples reveal the type of interactions that occur between the narrator and the reader. In some cases, the narrator gains the reader's favor by sharing information, such as a historical note or a character's thoughts. In other cases, the need to manage the reader's assumptions or implied questions motivates the narrator. Although information about history or characters could prove obtrusive, omniscient comments about the divine have greater obtrusive potential because the narrator may use the divine to interpret situations while, at other times, feel compelled to explain the actions of God.

Figures 2 and 3 offer succinct lists of selected narrative comments from categories "a" and "b" in the book of Joshua.

\begin{tabular}{|c|c|c|c|}
\hline Pass. & Context & Key Quote & Significance \\
\hline $\begin{array}{c}\text { Josh } \\
5: 4-7\end{array}$ & $\begin{array}{c}\text { Uncircumcised Israelites } \\
\text { entering the Promised } \\
\text { Land. }\end{array}$ & $\begin{array}{c}\text { "This is the reason why Joshua } \\
\text { circumcised them" }(5: 4, \mathrm{NRSV}) .\end{array}$ & $\begin{array}{c}\text { Provides the reader with } \\
\text { necessary information for } \\
\text { understanding the story since } \\
\text { the reader may have wondered } \\
\text { why the Israelites had not been } \\
\text { circumcised as infants. }\end{array}$ \\
\hline $\begin{array}{c}\text { Josh } \\
6: 25\end{array}$ & $\begin{array}{c}\text { Aftermath of the victory } \\
\text { at Jericho and the fate of } \\
\text { Rahab. }\end{array}$ & $\begin{array}{c}\text { "Her [Rahab's] family has lived in } \\
\text { Israel ever since" (NRSV). }\end{array}$ & $\begin{array}{c}\text { Connects the story to the } \\
\text { reader's day and explains the } \\
\text { presence of the family of Rahab } \\
\text { in Israel. }\end{array}$ \\
\hline $\begin{array}{c}\text { Josh } \\
10: 13\end{array}$ & $\begin{array}{c}\text { Story of the sun standing } \\
\text { still upon Joshua's } \\
\text { request. }\end{array}$ & $\begin{array}{c}\text { "Is this not written in the Book of } \\
\text { Jasher?" (NRSV). }\end{array}$ & $\begin{array}{c}\text { Lends an air of authenticity by } \\
\text { connecting the story to another } \\
\text { book. }\end{array}$ \\
\hline
\end{tabular}

Figure 2. Category a. Etiological/"Historical" 


\begin{tabular}{|c|c|c|c|}
\hline Pass. & Context & Key Quote & Significance \\
\hline $\begin{array}{c}\text { Josh } \\
7: 5\end{array}$ & First battle with Ai. & $\begin{array}{l}\text { Because of Israel's defeat, "the } \\
\text { hearts of the people melted and } \\
\text { turned to water" (NRSV). }\end{array}$ & $\begin{array}{l}\text { The emotional state of the } \\
\text { people is mentioned in spite of } \\
\text { the general reticence of the } \\
\text { narrator to discuss emotion. }\end{array}$ \\
\hline $\begin{array}{l}\text { Josh } \\
8: 14\end{array}$ & Second battle with Ai. & $\begin{array}{l}\text { "for he [the king of Ai] was } \\
\text { unaware that a force was lying in } \\
\text { ambush behind the city" (TNK). }\end{array}$ & $\begin{array}{l}\text { Speaks to a character's lack of } \\
\text { knowledge, allowing the } \\
\text { narrator to share the omniscient } \\
\text { perspective with the reader. }\end{array}$ \\
\hline $\begin{array}{l}\text { Josh } \\
8: 15\end{array}$ & Second battle with Ai. & $\begin{array}{l}\text { "And Joshua and all Israel made a } \\
\text { pretense of being beaten before } \\
\text { them" (NRSV). }\end{array}$ & $\begin{array}{l}\text { Explains the actions of some } \\
\text { characters as well as the lack of } \\
\text { knowledge of other characters. }\end{array}$ \\
\hline $\begin{array}{l}\text { Josh } \\
9: 16\end{array}$ & $\begin{array}{c}\text { The Israelites regret their } \\
\text { treaty } \\
\text { with the Gibeonites. }\end{array}$ & $\begin{array}{l}\text { "they [the Israelites] heard that } \\
\text { they [the Gibeonites] were their } \\
\text { neighbors and were living among } \\
\text { them" (NRSV). }\end{array}$ & $\begin{array}{l}\text { The narrator reinforces the } \\
\text { omniscient perspective already } \\
\text { shared with the reader at the } \\
\text { beginning of the chapter. }\end{array}$ \\
\hline $\begin{array}{l}\text { Josh } \\
10: \\
1-2\end{array}$ & $\begin{array}{l}\text { Impetus behind coalition } \\
\text { attack on Gibeon }\end{array}$ & $\begin{array}{l}\text { "When King Adoni-zedek of } \\
\text { Jerusalem learned that Joshua had } \\
\text { captured Ai ... he was very } \\
\text { frightened" (TNK). }\end{array}$ & $\begin{array}{l}\text { Connects knowledge with } \\
\text { emotion, showing why a } \\
\text { character acts a particular way. }\end{array}$ \\
\hline
\end{tabular}

Figure 3. Category b. Character Information ${ }^{152}$

Category c., Information about the Divine reveals that the narrator's insight into

God's actions and motivations increases the trust the reader places in the narrator.

According to Bar-Efrat, the fact that the narrator possesses knowledge about God raises

the narrator's status: “The evidence par excellence of the narrator's unlimited knowledge

is undoubtedly what is reported about God, whose feelings, thoughts, intentions, opinions

and judgments the narrator purports to know." ${ }^{\prime 53}$ Some of this category's best examples

come from the book of Judges as the Figure 4 shows. ${ }^{154}$

${ }^{152}$ For more on the psychology of characters, see Bar-Efrat on Gen 26:7; Judg 13:15-16; 2 Sam 13:22; 1 Kgs 5:1 [Efrat incorrectly lists 5:15]; Job 2:13 (Narrative Art, 30-31). Also, note his argument that "even though they use the third person for narration, the narrators adopt the optical or psychological point of view of that character, while they themselves are concealed, as it were" (35).

${ }^{153}$ Bar-Efrat, Narrative Art, 19.

${ }^{154}$ Since God is an active character in the book of Joshua who regularly speaks to Joshua, information about the divine specifically from the voice of the narrator is more difficult to find. 


\begin{tabular}{|c|c|c|c|}
\hline Pass. & Context & Key Quote $^{155}$ & Significance \\
\hline $\begin{array}{l}\text { Judg } \\
2: 18\end{array}$ & $\begin{array}{l}\text { Framing the reason for the } \\
\text { judges. }\end{array}$ & $\begin{array}{l}\text { "the Lord raised up judges } \\
\text { for them . . . for the Lord } \\
\text { would be moved to pity by } \\
\text { their groaning." }\end{array}$ & $\begin{array}{l}\text { Divine action based on divine } \\
\text { emotion. }\end{array}$ \\
\hline $\begin{array}{l}\text { Judg } \\
2: 22\end{array}$ & $\begin{array}{l}\text { Explaining the nations } \\
\text { remaining in Judges in spite } \\
\text { of Joshua's conquest. }\end{array}$ & $\begin{array}{c}\text { "in order to test Israel } \\
\text {... the Lord had left those } \\
\text { nations." }\end{array}$ & $\begin{array}{l}\text { An attempt to reconcile the } \\
\text { different situations in Joshua } \\
\text { and Judges. }\end{array}$ \\
\hline $\begin{array}{l}\text { Judg 3: } \\
10-12\end{array}$ & $\begin{array}{l}\text { The Lord raises up both } \\
\text { judges and persecutors. }\end{array}$ & $\begin{array}{l}\text { "the spirit of the Lord came } \\
\text { upon him and he judged } \\
\text { Israel ... and the Lord } \\
\text { strengthened Eglon King of } \\
\text { Moab against Israel." }\end{array}$ & $\begin{array}{l}\text { Divine causality related to both } \\
\text { the people's deliverance and } \\
\text { their persecutions. }\end{array}$ \\
\hline
\end{tabular}

Figure 4. Category c. Information about the Divine

In these examples, the narrator utilizes divine causality to answer some of the assumptions and implied questions of the reader in Judges. Judg 2:18 and 3:10-12 help to form the framework of the book while 2:22 seeks to harmonize Joshua and Judges through the use of divine causality. ${ }^{156}$

The Binding of Isaac and the Reader

Since information about the divine reveals omniscience and often presents obtrusive possibilities, I turn to Gen 22 to test my methodology. Although the literary economy of this chapter reveals its artistic qualities, the terse narrator acts out of character by intervening in the first verse to inform the reader of God's testing of

Direct speeches from God diminish in the book of Judges: the people inquire of the Lord in ch. 1, then hear from an angel of the Lord in ch. 2, and then mainly hear from judges. The beginning chapters of Judges are more similar to Joshua than the later chapters in which God disappears into the background. Amelia D. Freedman notes that God gradually fades from the biblical narrative (God as an Absent Character in Hebrew Narrative: A Literary-Theoretical Study [ed. Hemschand Gossai; Studies in Biblical Literature 82; New York: Peter Lang, 2005], 1).

${ }^{155}$ All quotes in Figure 4 are from NRSV.

${ }^{156} \mathrm{I}$ address explanations for the remaining nations in chapter 4. For more on the connection between Joshua and Judges, see G. Ernest Wright, "The Literary and Historical Problem of Joshua 10 and Judges 1," JNES vol. 5, no. 2 (Apr. 1946): 105-14. 
Abraham. This comment may represent general omniscience or obtrusiveness, and scholars offer multiple explanations for its purpose in the chapter.

Rather than categorizing Gen 22:1 as an intrusion, Ska calls the verse an "abstract" or "title." Most of his other examples of abstracts, however, fall short of the obtrusive possibilities in Gen 22:1. ${ }^{157}$ Since abstracts often foreshadow events, Ska also categorizes the verse as a prolepses or anticipation. ${ }^{158} \mathrm{He}$ explains that "modern authors tend to avoid prolepses because they may reduce the narrative tension and diminish the reader's interest. But when we 'know the end' from the outset, our attention can focus more on the "how' of the concrete narration than on the "what' of the 'story." ${ }^{159}$ Gen 22:1, however, hardly seems like foreshadowing since God immediately announces the test in verse 2 .

By making the reader aware of the test in verse 1, the narrator may raise the status of the reader; but if the comment is an obtrusion, then the narrator lowers the reader's status. By sharing omniscient information, the narrator raises the reader above characters who lack knowledge about the test. Ska views the verse as "reader-elevating" because "the reader knows that God tests Abraham but the patriarch remains in the dark until vv.

${ }^{157}$ Ska, "Our Fathers," 31. His other examples include the following. Gen 18:1 tells of the Lord appearing to Abraham. Gen 28:10 tells of Jacob going from Beersheba to Haran. Ex 3:2a explains that the angel of the Lord was in the fire in the bush. $2 \mathrm{Kgs}$ 2:1 foreshadows that Elijah will be taken up into heaven.

${ }^{158}$ Ska, "Our Fathers," 8, 31, 34.

${ }^{159}$ Ska, “Our Fathers, " 8. Two of Ska's examples of prolepses (Ex 6:6-8; 7:1-5) feature the Lord telling Moses what will happen in the future. His third example, 2 Sam 17:14b, has the foreshadowing of Absalom's defeat coupled with a narrative explanation employing divine causality as the reason why Ahithophel's advice was defeated. This explanation seems obtrusive because it explains how God had preordained which counselor would win in order to ensure Absalom's defeat. Additionally, since the narrator informs the reader of God's intervention to defeat Ahithophel's advice in order to judge Absalom, suspense is limited. 2 Sam 17:14b also better fits the definition of foreshadowing than Gen 22:1 since Joab does not kill Absalom until the next chapter. 
11-12."160 The narrator, however, may have a very specific reason for communicating this information to the reader. If the narrator seeks to inhibit rather than inform reader response, then the narrator diminishes the reader's status.

The narrator may have additional motives for the comment. Perhaps the verse is not an obtrusion because the narrator inserts the editorial note about God testing Abraham in order to balance an already "overwhelming suspense."161 The narrator's motivation plays a key role in determining general omniscience or obtrusiveness. If the narrator redirects narrative tension in order to prevent the reader from making questionable assumptions about God, then the verse decreases the reader's status. By focusing narrative tension on questions about Abraham's potential actions, the narrator deflects similar queries about the divine. G. W. Coats observes an overall reduction in narrative tension because the narrator seemingly guarantees the safety of Isaac. ${ }^{162}$ In contrast, André Wénin argues that narrative tension increases because the reader lacks access to Abraham's thoughts since the narrator provides little character information about the patriarch and delays action in vv. 4-8. ${ }^{163}$ By explaining God's motivations in Gen 22:1, the narrator focuses the reader on the moral situation placed in front of Abraham, simultaneously reducing reader concerns about God and raising tension about Abraham. The narrator further lessens tension about the divine by allowing readers to see

\footnotetext{
${ }^{160}$ Ska, “Our Fathers, ” 55.

161 Auerbach, Mimesis, 11.

${ }^{162}$ G. W. Coats, “Abraham's Sacrifice of Faith: A Form-Critical Study of Genesis 22,” Int 27 (1973): 389 400.

163 André Wénin, Isaac ou l'épreuve d'Abraham: Approche narrative de Genèse 22 (Bruxelles: Éditions Lessius, 1999), 37-43.
} 
everything unfold from the perspective of God. If a motivation to protect God causes the narrator to redirect the reader's attention, then the verse may prove obtrusive.

\section{Reader Questions}

The narrator may act obtrusively in anticipation of reader questions. Reader questions in the biblical text may arise from (1) reader expectations shaped by forms and conventions, (2) reader expectations shaped by knowledge of a tradition or story, (3) a previously established fact being called into question by the narrator, and (4) the introduction of a new fact by the narrator. The forms and conventions of a reader's literary culture create expectations that will lead to questions if the narrator deviates from them. While Luis Alonso-Schökel states that the narrator should be able to use "conventions without being dominated by them," forms and conventions affect reader expectations if a form is changed or a convention is not followed. ${ }^{164}$ For example, stories about biblical heroes often include birth narratives as in the accounts of Moses and Samuel. As a result, some ancient readers may wonder why the narrator never mentions David's birth. Yair Zakovitch argues that the story of David omits the protagonist's birth not only due its incompatibility with a Cinderella type story like David's, but also because it would interfere with the narrator's objective of having the narrative of David's life eclipse the story of Saul. ${ }^{165}$ True to the Cinderella theme, David's great promise is

\footnotetext{
${ }^{164}$ Alonso-Schökel, A Manual of Hebrew Poetics, 10-11.

${ }^{165}$ It is also possible that youth and birth stories are equivalents.
} 
made known — not at birth—but on the battlefield with Goliath and at his anointing. ${ }^{166}$

By choosing a different format for the story, the narrator defies reader expectations.

Though not bound to one form in tales of heroes, the narrator may still create reader questions.

The narrator may also fail to meet reader expectations by diverging from an oral tradition well known to the ancient reader. ${ }^{167}$ In spite of the difficulty involved in finding such divergences, the narrative of Samson shows evidence of a narrator veering away from an oral tradition. The narrator may have removed some conventional narrative elements in order to rework the tradition for a new purpose. As a result, ancient readers may have found "de-mythologization" as well as a "taming of eroticism" in the story. ${ }^{168}$ Readers may have approached the story expecting to see a version of the story similar or identical to the one they had heard, only to observe radical changes made to the narrative. $^{169}$

\footnotetext{
${ }^{166}$ Yair Zakovitch, "David's Last and Early Days," in From Bible to Midrash: Portrayals and Interpretive Practices (ed. Hanne Trautner-Kromann; Scandinavian Jewish Studies 10; Lund: Arcus, 2005), 37-52.

${ }^{167}$ While scholars cannot recreate retellings of these stories, they can look to the ways in which stories are told and retold in certain biblical texts. For an examination of this issue, see Jack M. Sasson, "The Servant's Tale: How Rebekah Found a Spouse” JNES 65 (2006): 241-65. See also Klaus Seybold, "Erzählen vom Erzählen. Beobachtungen zu einer biblischen Erzähltheorie," TZ 61 (2005): 14-26. See also Claus Westermann who traces the history of stories in the Hebrew Bible, noting their composite nature and the way the narrators reframed oral traditions into new narratives. He offers the reworking of ancient Near Eastern myths and legends in Gen 1-11 as an example of stories being reworked for a different purpose by the biblical narrators (Erzählungen in den Schriften, 21).

${ }^{168}$ Zakovitch, "David's Last and Early Days," 23, 31. For a discussion of the way the biblical narrators changed the encounter between Noah and Ham and the encounter between Reuben and Bilhah, see Sarna, "The Anticipatory Use," 212. Sarna also suggests that the narrator had to deal with the reader's knowledge of a tradition through anticipations, such as when Lot separates from Abraham toward Sodom and Gomorrah - an act which forces the narrator to state that this event occurred before the destruction of these cities (214-25).

${ }^{169}$ This same reshaping occurs in the modern world when speechwriters and homileticians adapt narratives in ways that often run counter to the original storyteller's intent as well as popular interpretations of the story.
} 
Reader queries not only arise from re-imaginings of a story but also when the narrator calls a previously established fact into question. In these cases, the narrator creates a retroactive continuity by altering these facts in order to explain current circumstances. For example, Judges' explanation of why God left other nations in the land goes against the grain of the narrative due to the established fact that Joshua had led the Israelite conquest over the land. Several passages seem like a retroactive continuity of the Deuteronomistic History used to connect Joshua with Judges. ${ }^{170}$

Narrators employ retroactive continuities in an attempt to harmonize narratives. Although a harmonization occurs on a large scale when the narrator connects the conquest of Joshua with the chaos of Judges, harmonizations also occur on a smaller scale, such as when the narrator endeavors to unite the portrait of David as musically talented shepherd with the picture of David as a skilled fighter. When 1 Sam 16:18 describes David as both a skillful musician and a warrior, Alter believes that "the reference to David's martial prowess looks suspiciously like an attempt to harmonize Chapter 16 and Chapter 17, perhaps even by a later editor, for there has been no suggestion up to this point that the young shepherd David had any military experience, and if he were already known as a formidable warrior, it would make no sense for Saul to give him the menial role of armor-bearer (I Sam 16:21)."171 As a very specific type of redaction, retroactive continuities may appear more obvious than other forms of editing;

\footnotetext{
${ }^{170} \mathrm{I}$ address this issue more fully chapter 4.

${ }^{171}$ Alter, The Art of Biblical Narrative, 150. In spite of this attempted harmonization, problems persist. Bar-Efrat writes, "no attempt is made to resolve the discrepancy deriving from the fact that in the narrative of David and Goliath Saul does not know David (17.55-58), while in the previous one David found favour in Saul's sight and Saul loved him greatly (16.21-22)" (Narrative Art, 134-35).
} 
however, intrusive edits vary by degree with some having more obtrusive potential than others.

Simple harmonizations, which attempt to unite two different sources in one story, may require minimal intrusions by the narrator. ${ }^{172}$ More difficult harmonizations may necessitate the use of divine causality, leading the narrators to take omniscience beyond obtrusiveness by utilizing the omnipotence of God. The divine is a powerful character available to the narrator. In Judges 2:22, the narrator utilizes God to explain the remaining nations as a test for Israel and, thereby, harmonize Joshua and Judges. The narrator enters the realm of obtrusiveness in order to deal with a reader question about a previously established fact.

The narrator's introduction of new facts may also provoke reader questions. For example, the narrator of Josh 5 tells of the uncircumcised state of the Israelites who entered the Promised Land. Without this new information, readers would conventionally associate circumcision with infancy. The introduction of this omniscient comment immediately makes the reader wonder why this generation of Israelites remains uncircumcised, and the narrator must provide an answer.

By defying convention, deviating from oral tradition, disestablishing facts, and introducing previously unknown information, the narrator generates questions in the mind of the reader. In the examples of diverging from convention and oral tradition, the narrator rarely offers an explanation behind the editorial changes and may diminish reader trust. In the examples of established and new facts, the narrator deals with larger

\footnotetext{
${ }^{172}$ If popular stories were reframed for sacred uses, it raises the interesting but difficult question of whether the narrators changed divine elements that they felt were inconsistent with their worldview, kept sacred elements in the text, or added sacred elements to the text. For the idea that the narrators made minimal changes to the text because they viewed the original as inspired, see Seybold, Poetik, 277.
} 
issues that may prove troubling to the reader. When the narrator brings an established fact into question, the narrator attempts to address the matter through harmonization. In relating a new fact, the narrator purposely creates a problem that drives the plot by forming a question in the mind of the reader.

\section{The Reader's Effect on the Narrator}

Although the narrator greatly influences the reader by creating questions, providing omniscient knowledge, and occasionally obtruding, the reader's effect on the narrator deserves more consideration. The narrator and reader form a dialogue because the narrator anticipates the response of the reader, and the reader responds to the narrator. Because the relationship between the reader and the narrator forms a dialogue rather than a one-way communication, combining narrative criticism with reader response again proves beneficial. Such an endeavor requires extrapolating some of the principles of narrative criticism and reimagining them in conjunction with reader response. Marguerat and Bourquin examine the "narrative strategy directed at the reader" by considering pragmatic reading: "a method of reading which questions the text in terms of the effects it has on the reader: it discovers in it the pragmatic indications which are instructions suggesting to the reader the way in which the text is to be received." ${ }^{173}$ While this definition focuses on the structures created by the narrator for the purpose of influencing the reader, perhaps the narrator forms structures and provides comments in order to answer anticipated questions from the reader. In this way, the reader shapes the narrator.

\footnotetext{
${ }^{173}$ Marguerat and Bourquin, How to Read Bible Stories, 8.
} 
The narrator may sometimes makes comments in order to prevent readers from formulating a particular question. Alonso-Schökel observes that "the text also poses its questions to the reader, and may correct the reader's questions, thus establishing a dialogue." ${ }^{174}$ Perhaps the fear of certain questions or the need to correct potential assumptions caused the narrator to act in an obtrusive manner.

\section{An Obtrusive Narrator}

Although sometimes behaving obtrusively, the narrator often remains laconic, selective, "invisible and undramatized" out of respect for the divine. ${ }^{175}$ The narrator uses God-like literary powers by displaying omniscience but, at the same time, remains subservient to an omniscient and omnipotent God. George Savran writes,

we have seen how the narrator is absolutely authoritative within the confines of a literary construct, and, at the same time, passive in terms of the theological universe which he describes. In order to get around this dilemma, the biblical narrator must efface his own presence by remaining anonymous, and by presenting his material in a manner which is ostensibly neutral and objective. But he who appears merely to report on the happenings of a divinely ordered cosmos also comments on that story with great subtlety. ${ }^{176}$

Every so often the narrator defies this subtlety and more forcefully influences the reader.

\footnotetext{
${ }^{174}$ Luis Alonso-Schökel, A Manual of Hermeneutics (with José María Bravo; trans. Liliana M. Rosa; further editing by Brook W. R. Pearson; Biblical Seminar 54; Sheffield: Sheffield Academic, 1998), 85. For more on reader expectations and the structuring of the text, see Roland Barthes, $S / Z$ (trans. Richard Miller; London: Jonathan Cape, 1975). See also Douwe W. Fokkema, Theories of Literature: Structuralism, Marxism, Aesthetics of Reception, Semiotics (New York: St. Martins, 1978), 20-22.

${ }^{175}$ See Ska, “Our Fathers Have Told Us, ” 45-46.

${ }^{176}$ George Savran, “The Character as Narrator in Biblical Narrative," Proof (Jan. 1985): 11-17.
} 
The terse narrator generally affects the reader by providing very little description, and this lack of detail often generates suspense. Gerhard von Rad observes that in Genesis 22 the "narrator exerts a chaste reticence on the emotional side.", 177 Auerbach finds it "unthinkable" that anything in the story should be described. ${ }^{178}$ In contrast to Homeric narrative, this general absence of description heightens suspense in the story: "the descriptive adjectives and digressions of the Homeric poems . . p prevent the establishment of an overwhelming suspense. But here, in the story of Abraham's sacrifice, the overwhelming suspense is present . . . God gives his command in direct discourse, but he leaves his motives and his purpose unexpressed." ${ }^{\prime 19}$ And yet, readers still know that God is testing Abraham. Perhaps the narrator diverted readers from this suspenseful path due to the troubling questions that readers might raise about the divine.

Edna Coffin believes that the terse nature of the narrator generally leaves many questions unanswered: "the reader participates in the [narrative] experience by raising basic questions for which no answers are given." 180 Although Coffin's comment may make gaps seem more acceptable in biblical narrative, the fact that the narrator provides an answer in Gen 22:1 raises questions about the motive behind the obtrusion.

\footnotetext{
${ }^{177}$ Rad, Genesis, 240.

${ }^{178}$ Auerbach, Mimesis, 9-12.

${ }^{179}$ Auerbach, Mimesis, 9-12.

${ }^{180}$ Edna A. Coffin, “The Binding of Isaac in Modern Israeli Literature," $M Q R$ (1985): 429-44.
} 


\section{Addition and Subtraction of the Obtrusion}

Since omniscient comments often present essential information and obtrusive comments represent elaboration or intervention by the narrator, the effect of deleting both types of comments merits consideration. ${ }^{181}$ The removal of some basic editorial comments that display general omniscience might have little effect on the reader. However, omniscient comments that aid reader understanding often prove necessary to a story since omitting them would produce a perplexing gap. In contrast, the omission of obtrusions could create questions that would trouble the narrator.

In thinking about the three categories of narrative information (etiological/“historical” information, character information, and information about the divine), some "historical" references could be eliminated from a story. For example, reader understanding would suffer very little from omitting references to a heap of stones remaining "unto this day." Etiologies, however, differ from other historical references because they represent the entire reason for telling a story. Because etiologies answer questions of origin, they provide essential information. Although some questions arise in the process of reading, etiologies may point to an initial question that led to the telling of a story. For example, a question about the name "Valley of Achor" may have compelled

\footnotetext{
${ }^{181}$ I am not omitting comments in the same way historical critics sometimes like to discard the redactional elements of a story. Rather I am following Anthony Campbell's advice that "the point is not to dismiss what has been identified as external, but to see what meaning is given by its use or insertion" ("Form Criticism's Future" in The Changing Face of Form Criticism for the Twenty-First Century [ed. Marvin A. Sweeney and Ehud Ben Zvi; Grand Rapids, Mi.: W. B. Eerdmans, 2003], 15-31).
} 
the narrator to relate the story of Achan. This etiological explanation represents the impetus behind the narrative rather than an obtrusion. ${ }^{182}$

Comments about characters may provide general omniscient information or even prove obtrusive. The story of Amnon and Tamar provides a note that associates Tamar's multi-colored garment with virginity and assists the reader in understanding the story. But the omission of this gloss would only minimally affect the reader and Tamar. Readers would recognize the convention of mourning while failing to fully comprehend the significance of her clothing. ${ }^{183}$ Nevertheless the gap formed by omitting this explanation would be nominal compared to other narrative comments. In contrast, information explaining someone's motivations proves more obtrusive. Such is the case in 2 Sam 3:37 where the narrator informs the reader that everyone in Israel knew that David had nothing to do with Abner's death. ${ }^{184}$ Coupled with references in which the narrator places David as far away from culpability as possible in the death of Saul (2 Sam 1), this comment seems highly obtrusive - especially since it also absolves David of Isbosheth's death. ${ }^{185}$ Without this explanation protecting the character, readers might ask questions

\footnotetext{
${ }^{182}$ I leave open the possibility that an etiology can reframe a story because it is not always possible to discern a story's original intent. In such cases, reader are left to trust the interpretation of the narrator.

${ }^{183}$ Tony W. Cartledge refers to this note as "a brief parenthesis" and compares Tamar's mourning to the actions of a grieving widow $(1 \& 2$ Samuel [Smith \& Helwys Bible Commentary; Macon, Ga.: Smith \& Helwys, 2001,] 538-39). See also P. Kyle McCarter, II Samuel: A New Translation with Introduction, Notes and Commentary; AB 9; Garden City: Doubleday, 1984), 325-26.

${ }^{184}$ Even without comments such as these, Bar-Efrat believes that it is possible to find the narrator's view of a character-no matter how subtle or inobtrusive it may be (Narrative Art, 32-33). For more on the narrator's attempt to exonerate David, see Steven L. McKenzie, King David: A Biography (Oxford; New York: Oxford University Press, 2000), 117-22.

${ }^{185}$ Bar-Efrat discusses the connections between omniscience and characterization: "The character's knowledge or lack of it is important either for the characterization or for the development of the plot ... for instance, David's lack of knowledge is extremely significant as regards his morality: his ignorance absolves him of all blame in the murder of the two commanders of the army; at the same time David's lack of
} 
about the king that the narrator would find unpleasant. If the narrator goes to great lengths to exonerate David through an obtrusion, then the narrator will probably do the same and perhaps even more for God. ${ }^{186}$

This possibility of using an obtrusion to protect the divine again raises the question of whether Gen 22:1 fits into the category of general omniscience or obtrusiveness. On the one hand, the testing comment presents essential information to the reader and seems to reflect general omniscience. On the other hand, this narrative interruption aims to preemptively silence reader questions about the character of God much like the narrator tried to exculpate David. Although not an elaboration, the comment seems like an "obvious intervention by the narrator.", 187

Removing the note about God's testing of Abraham would greatly change the way the reader perceives God's motives because the verse prevents the reader from having "any premature excitement regarding a horrible experience." ${ }^{188}$ By including the information about testing, the narrator forces the reader to attend to the suspenseful actions of Abraham. Without the comment, the reader's focus might shift to attempted explanations of God's command. Despite the necessity of the comment, Coats finds it inadequate and disquieting: "it would have been nice if the text had provided some more

\footnotetext{
knowledge places the full responsibility on Joab (characterization of Joab), which is the reason for the assassination at Solomon's order (plot)" (Narrative Art, 61).

${ }^{186}$ For more on the way the narrators seem to present characters objectively while offering subtle hints as to their feeling about the character, see Bar-Efrat, Narrative Art, 32-33.

${ }^{187}$ Alter, The Art of Biblical Narrative, 184.

${ }^{188} \mathrm{Rad}$, Genesis, 239. For more on the reassuring nature of the verse and its ability to "allay the reader's anxiety," see Louis A. Berman, The Akedah: The Binding of Isaac (Northwale, NJ.; Jerusalem: Jason Aronson, 1997), 13. See also E. A. Speiser, trans. Genesis, Anchor Bible (Garden City: Doubleday, 1964), 164; and Jacob Licht, Storytelling in the Bible (Jerusalem: Magness, 1978), 116.
} 
satisfying insight into God's character than the image provided by a God who would play a devious game with an obedient creature. But there is none. The text never raises questions about what kind of God would be asking such a horrifying confirmation of obedience and loyalty." 189 If Coats desires an even more obtrusive narrator, then perhaps the verse represents general omniscience.

The Location of the Obtrusion

In determining obtrusiveness, the location of the narrative intrusion also demands consideration. Even in those cases where the narrator relates essential information to the reader, an obtrusion may still exist if the location of the obtrusion hinders the reader from asking questions. This type of narrative intervention occurs in Gen 22:1. Although the insertion of the comment removes a potential gap from the narrative, its placement at the beginning of the story completely inhibits readers from forming an opinion about the situation. The location of the obtrusion is related to time in the narrative. Meir Sternberg makes an important connection between gaps and narrative time: "all gaps result from discontinuities between the order of narration and the order of occurrence, with its straight chronology. But it makes a considerable difference whether what happened at a certain point in the action emerges in the narration later or not at all." ${ }^{190}$ Most gaps occur in a story when the narrator completely leaves out a piece of information. However, a

\footnotetext{
${ }^{189}$ Coats, “Abraham's Sacrifice,” 398.

${ }^{190}$ Sternberg, The Poetics of Biblical Narrative, 236-37. For more on gaps, see also Shlomith RimmonKenan, Narrative Fiction: Contemporary Poetics (2nd ed.; London; New York: Routledge, 2002), 126-30.
} 
delay in presenting knowledge to the reader may also create a gap. For example, the narrator may form a gap by delaying the answer to a reader's implied question.

Obtrusions not only fill in gaps, but they may also reframe an original story. Perhaps the narrator of Gen 22 reworked the earlier story by changing its objective. For example, the story may have originally focused on child sacrifice. ${ }^{191}$ Based on gaps in the story, such as the fact that Isaac does not return with Abraham, this scenario is plausible. The narrator, however, may have worried about some vestigial elements from this narrative. In considering the possibility that the story represents an etiology reflecting a time when the deity required child sacrifice, Coats points out that "at this stage in the development of the story, the question of God's character is at stake." ${ }^{192}$ Even an inkling of this memory may have led the narrator to divert the reader's attention away from this possible path and reframe the story.

The narrator's testing explanation in Gen 22:1, not only reframed the story, but the obtrusion reframed the entire narrative of Abraham as interpreters of Genesis retroactively deemed several previous events in Abraham's life as tests. ${ }^{193}$ According to Avot 5.3, the Aqedah represents the culmination of a series of 10 tests. Interpreters even

\footnotetext{
${ }^{191}$ Yitzak Avishur notes that "opinions differ as to the intention of this narrative: some emphasize the text, some the holiness of the place, and some the rejection of human sacrifice, and its replacement by animal sacrifice. Some experts hypothesize that earlier versions of the story existed with different intentions, and these were absorbed in the final formulation of the narrative and what was principal in the old version became secondary in the new" (Studies in Biblical Narrative: Style, Structure, and the Ancient Near Eastern Literary Background [Tel Aviv-Jaffa: Archaeological Center Publication, 1999], 96). For other possible interpretations of Gen 22:1, see Omri Boehm, The Binding of Isaac: A Religious Model of Disobedience (ed. Claudia V. Camp, Andrew Mein; Library of Hebrew Bible/Old Testament Studies 468; New York; London: T \& T Clark, 2007).

${ }^{192}$ Coats, “Abraham's Sacrifice,” 399.

${ }^{193}$ James L. Kugel, Traditions of the Bible: A Guide to the Bible As It Was at the Start of the Common Era (Cambridge, Mass.; London: Harvard University Press, 1998), 297-307.
} 
deemed the opening phrase of Gen 22:1 as evidence of others tests since "these things" might refer to previous trials. ${ }^{194}$ The force of the obtrusion completely reordered interpretations of Abraham.

The obtrusion greatly affected the larger Abrahamic narrative, but the narrator's choice to locate it at the beginning of the story shows that the narrator wished to protect the divine from uncomfortable questions. Although the narrator prevents Abraham from learning about God's motivations, the narrator may have felt uncomfortable leaving the reader in the dark for too long. Although the story could have ended with the words, "Thus God tested Abraham," the narrator chose to inform the reader about God's motives at the beginning of the narrative. The narrator strategically inserts information to avoid giving the reader even the slightest opportunity to question the character of God. ${ }^{195}$

Perhaps the testing comment in Gen 22:1 represents editorial omniscience. Laurie Henry defines this potentially obtrusive type of omniscience as "the effect created when a third-person narrator adds his own remarks, presumably representing the ideas and opinions of the author, into the narrative. ${ }^{, 196}$ Laurie's example of editorial omniscience proves far more telling than this definition. Laurie references Grimm's "Godfather Death," a story in which the narrator tries to exonerate God. When a poor man tells God that he does not want God to be the father of his child because "You give to the rich and let the poor go hungry," the narrator intervenes to inform the reader that the man "did not

\footnotetext{
${ }^{194}$ Kugel, Traditions, 297.

${ }^{195}$ Of course, it is also possible that the narrator wishes to bring the character of God into question to heighten the suspense in the story.

${ }^{196}$ Laurie Henry, The Fiction Dictionary (Cincinnati, Oh.: Story, 1995), 90.
} 
understand how wisely God shares out wealth and poverty."197 The narrator of the Aqedah may have similar goals. Even though von Rad argues that this narrator "does not intend to hinder" the reader, perhaps the narrator strives to exonerate the divine by binding the reader with an obtrusion that impedes the questioning of God's motives. ${ }^{198}$

Having God as character in this narrative creates problems for the narrator and forces the narrator to break certain rules in an attempt to protect God. For example, while Auerbach praises the Hebrew narrators for having characters with more freedom of choice than their Homeric counterparts, these same narrators restrict a character with ultimate power. Even without a comment explaining God's testing of Abraham, readers could assume that God has the authority to do as the divine pleases. The narrators also act contrary to their main objectives in order to more clearly define God. Alter writes, "an essential aim of the innovative technique of fiction worked out by the ancient Hebrew writers was to produce a certain indeterminacy of meaning, especially in regard to motive, moral character, and psychology." ${ }^{199}$ Perhaps the narrator objected to leaving these particular interpretative possibilities open to readers when dealing with the divine.

The narrator places similar restrictions on the reader of Gen 22 as Kazuya Akimoto notes: "the narrator conceals what is in the mind of God and protects the authority of God." ${ }^{200}$ Since an omnipotent God is absolute, the narrator wanted to inhibit the reader's desire to ask questions about God's motive and character. Unlike other

\footnotetext{
${ }^{197}$ Henry, The Fiction Dictionary, 90.

${ }^{198} \mathrm{Rad}$, Genesis, 243-44.

${ }^{199}$ Alter, The Art of Biblical Narrative, 21.

${ }^{200}$ Kazuya Akimoto, “A Multiple Theoretical Approach to Genesis 22: Rebinding the Aqedah” (Master's Thesis; Vanderbilt University, 2003), 47-48.
} 
figures, the character of God cannot be "a matter of conjecture" or of "teasing multiple possibilities."201

The biblical narrators not only strove to eliminate questions about the divine, but they also invoked the divine to tie up loose ends in narratives. The test of Abraham in Gen 22:1 is an obtrusion that attempts to explain God's actions and exonerate God. In contrast, the testing of the Israelites in Judg 2:22 reveals that the narrator utilized the omnipotence of God in an obtrusion to explain disparities between the books of Judges and Joshua. $^{202}$

\section{Gaps}

In some cases, the narrator provides no explanation and simply leaves a gap in the text. Because the narrator fills in some gaps with obtrusions, but not others, questions arise as to whether the narrator failed to foresee a reader's implied question or simply chose not to answer it. ${ }^{203}$ For example, the narrator begins the Aqedah with an obtrusion but allows certain gaps to remain in the story. James Crenshaw believes that since "God always recedes into the depths," narrative economy creates gaps in the text and leaves some reader questions unanswered, such as why God gave the test, why God stopped

\footnotetext{
${ }^{201}$ Alter, The Art of Biblical Narrative, 158.

${ }^{202}$ Other examples of testing which use include Exod. 20:20; Deut 8:16; 13:3; $33: 8$ (cf. 1 Kgs 17:39). See also uses of בחן-Ps. 17:3; 26:2; 66:10; 81:7; Prov 17:3; 1 Chr 29:17; Jer 6:27; 9:7; 11:20; 12:3; 17:10; 20:12.

${ }^{203}$ Since the narrator provides information about characters, readers may sometimes wonder how a character acquired a particular piece of information. For discussion of the knowledge which characters possess without the narrator filling in the gaps to explain their knowledge, see Jean Louis Ska, "De quelques ellipses dans les récits bibliques," Bib 76 (1995): 63-71.
} 
Abraham, and why the narrator never mentions Sarah. ${ }^{204}$ Berlin connects gaps to literary artistry, noting that since "too much information may destroy the illusion ... The trick, then, from the artist's point of view, is how much to include and how much to omit. What does the viewer need to construct the context, and what will the context allow him to project to complete the illusion that what he sees is real." ${ }^{205}$ This balance between inclusion and omission depends on the contributions of the reader.

In shaping the text, the narrator leaves gaps since the narrator depends on the reader to aid in the construction of meaning. Bar-Efrat notes that "as in real life, in literature in general and biblical narratives in particular, intentions may exist, however, which are not stated explicitly. (In the narrative of Bathsheba, for example, we are not told why David urges Uriah to go down to his house, yet there is no doubt in our minds what the king's purpose is)." ${ }^{" 206}$ Gaps may occur because the narrator assumed the reader could provide the missing information or because the narrator did not anticipate the reader's implied question. Obtrusions occur when the narrator objects to readers filling in these gaps.

The binding of Isaac contains evidence of narrative obtrusiveness, terseness, and gaps. Calling the Aqedah, a "fine example of both narratorial reticence and of gapping,"

\footnotetext{
${ }^{204}$ James L. Crenshaw, “Journey into Oblivion,” Soundings (Summer 1975): 251-52. See also Rémi Lack who characterizes Gen 22:3-4 as an gap since we are not told what happened during the journey to Moriah. The specifics of the trip, however, prove of little importance to the reader. The narrator hopes that the attentive reader will recognize the suspense created by Abraham's agony in contrast to Isaac's ignorance; but in the end, it is Abraham who gains more knowledge of God as the testing deity of verse 1 becomes the provider of vv. 13-14 ("Le sacrifice d'Isaac-Analyse structural de la couche élohiste dans Gn 22" Bib 56 [1975]: 1-12).

${ }^{205}$ Berlin, Poetics, 136-37.

${ }^{206}$ Bar-Efrat, Narrative Art, 250.
} 
David W. Cotter questions whether or not the reader really knows that Abraham will not sacrifice Isaac due to Abraham's willingness “to dispose of inconvenient members of his family [Sarah, Hagar, Ishmael], especially when the test is from God."207 Although Menakem Perry and Meir Sternberg observe that "the Binding of Isaac story [is] renowned in literary criticism as a story that leaves many details obscure," the narrator takes one of the main details out of the shadows and boldly places it in front of the reader. ${ }^{208}$ Readers know from the outset that the events that follow comprise a test. But just as the reader may often feel uncomfortable about gaps, the narrator may also worry about leaving too much up to the reader. Furthermore, Akimoto argues that omissions in the chapter represent "more than an economical use of language to emphasize the decisive points of the narrative. The narrator is a manipulator. In the narration, language is used to manipulate and cover up, not to reveal or communicate. The narrator states nothing inconvenient to carry out the purpose of the narrative." ${ }^{209}$ Perhaps the narrator's laconic nature and occasional obtrusions are more closely related than previously thought. The narrator may sometimes withhold information through gaps and, at other times, provide additional information through obtrusions - both for the purpose of influencing reader response.

\footnotetext{
${ }^{207}$ David W. Cotter, Genesis (ed. David W. Cotter, Jerome T. Walsh, Chris Franke; Berit Olam: Studies in Hebrew Narrative \& Poetry; Collegeville , Minn.: Liturgical, 2003), 146.

${ }^{208}$ Menakhem Perry and Meir Sternberg. "The King through Ironic Eyes: Biblical Narrative and the Literary Reading Process" (in Hebrew) Ha-sifrut 1:2 (Summer, 1968): 263-92. For the English reprint see, Poetics Today 7:2 (1986): 275-322.

${ }^{209}$ Akimoto, “A Multiple Theoretical Approach,” 59.
} 


\section{A Gap and an Obtrusion}

Both a gap and a narrative obtrusion occur in the story of Micaiah ben Imlah in I Kings 22. The chapter opens with the kings of Israel and Judah soliciting advice from prophets as they contemplate going to battle. In spite of the positive reports from numerous prophets, the king of Judah inquires about consulting another prophet. Although the king of Israel states that Micaiah always prophesies negatively to him, the court summons the naysaying prophet. When Micaiah arrives, he gives a prophecy that seemingly predicts a coalition victory. Nevertheless the king of Israel doubts his report, perhaps due to the way he states the prophecy. ${ }^{210}$ Although the king of Israel has noted Micaiah's typical interactions with him, the narrator chooses not to provide any additional reason explaining how the king discerned Micaiah's trickery. Perhaps the prophet spoke in a facetious tone or gave some other verbal or nonverbal clue about the deceitful prophecy. ${ }^{211}$ This lack of information reveals the gaps that narrators often leave in stories. The gap may even suggest an oral performance of the story with the storyteller providing the necessary inflection or gesture to communicate Micaiah's flippant prophecy. $^{212}$

\footnotetext{
${ }^{210}$ Exploring the idea that the narrator will sometimes protect the character of God requires pointing out the troubling aspect of a deity who has a lying spirit speak to his prophets. For a discussion of various interpretations of this story with the possibility of a more positive interpretation, see R. W. L. Moberly, "Does God Lie to His Prophets? The Story of Micaiah ben Imlah as a Text Case," HTR 96:1 (2003) 1-23.

${ }^{211}$ Contrast this scene with Hannah's silent prayer in which the narrator tells of her lips moving without her speaking (1 Sam 1:13). For a discussion of divine questions and answers in the work of the Deuteronomist, see Jack M. Sasson, "Oracle Inquiries in Judges," in Birkat Shalom: Studies in the Bible, Ancient Near Eastern Literature, and Postbiblical Judaism Presented to Shalom M. Paul on the Occasion of His Seventieth Birthday (ed. Chaim Cohen et al.; Winona Lake: Eisenbrauns, 2008): 149-68.

${ }^{212}$ For Alter's view on oral performance of the text, see Art, 90.
} 
While this omission creates a gap in the story, the chapter ends with an intrusion. After the king of Israel sentences Micaiah to prison until he comes home safe, Micaiah states, "If you ever come home safe, the LORD has not spoken through me." In a comment that may represent a later edit, the narrator writes, "He said further, "Listen, all you peoples!" Scholars have noted that this redaction may reveal a connection between Micaiah ben Imlah and the prophet Micah of Morosheth since "Listen, all you peoples" is the signature phrase of the latter. Walsh, however, characterizes this addition as a "footnote" without considering the larger implications behind the comment. ${ }^{213}$ If the Deuteronomistic narrators view these two figures as one and the same prophet, this link may reveal an attempt to create narrative unity between the texts, tying together disparate works. While historical criticism may argue against a historical connection between Micah and Micaiah, the strong literary connection created by the narrator deserves more attention than simply being relegated to a footnote. ${ }^{214}$

\section{The Rise of Obtrusiveness in Later Interpretations}

This exploration of the difference between omniscience and obtrusiveness necessarily turns to the history of interpretation. Narrative comments that have presented difficulties for later interpreters and scholars may reveal an obtrusive narrator at work. Later imaginings of the Aqedah add intrusive elements with the goal of exonerating God. For example, rabbinic interpretation translates the beginning of the Aqedah as "After

${ }^{213}$ Walsh, Style \& Structure, 153.

${ }^{214}$ For a summary of arguments attempting to locate the phrase in history, see Keith Bodner, "The Locutions of I Kings 22:28: A New Proposal," JBL 122/3 (2003): 533-46. I am not suggesting that the two are one and the same, but that the narrator saw a connection between them. 
these words," arguing that a speech by Satan caused God to test Abraham. ${ }^{215}$ Similarly, F. García Martínez notes that in the sacrifice of Isaac in 4Q225 "the Prince of Animosity" accused Abraham before God, leading God to call for the sacrifice of Isaac. ${ }^{216}$

The introduction of a character like the Prince of Animosity is also similar to the invoking of the divine by the biblical narrator. Although an evil figure, the Prince represents an otherworldly being who has the power to change the story. Even though both the narrator of Gen 22 and the narrator in 4Q225 focus on exonerating God, the introduction of this new character in 4Q225 provides an even better way of preventing uncomfortable questions from being asked by further shifting the focus away from God.

Martínez also connects 4Q225 with Jubilees 17:15-19 as well as the book of Job. ${ }^{217}$ Jubilees calls the new character in the re-imagining of the Aqedah, the "Prince of Mastema"- a figure similar to ha-Satan in Job. ${ }^{218}$ In shielding the character of God through the introduction of an otherworldly character, the narrator also protects the omniscience of God. Jacques van Ruiten argues that "it is important to the author of

${ }^{215}$ See Kugel, Traditions, 302.

${ }^{216}$ Florentino García Martínez, "The Sacrifice of Isaac in 4Q225," in The Sacrifice of Isaac: The Aqedah (Genesis 22) and Its Interpretations (ed. Ed Noort and Eibert Tigchelaar; Themes in Biblical Narrative, Jewish and Christian Traditions; Leiden; Boston; Köln: Brill, 2002), 45-57.

${ }^{217}$ F. García Martínez, "The Sacrifice of Isaac in 4Q225," in The Sacrifice of Isaac: The Aqedah (Genesis 22) and its Interpretations (ed. Ed Noort and Eibert Tigchelaar; Leiden; Boston; Köln: Brill, 2002), 44-57. For more on the connection between Gen 22 and Jubilees as well as the book of Job, see also Jacques van Ruiten, "Abraham, Job, and the Book of Jubilees: The Intertextual Relationship of Genesis 22:1-19, Job 1:1-2:12 and Jubilees 17:15-18:19," in The Sacrifice of Isaac: The Aqedah (Genesis 22) and its Interpretations (ed. Ed Noort and Eibert Tigchelaar; Leiden; Boston; Köln: Brill, 2002), 58-85.

${ }^{218}$ Texts such as Genesis Rabbah use the character of ha-Satan to deal with gaps in the Aqedah (Berman, The Aqedah, 73). See Jacob Neusner, trans., Genesis Rabbah: The Judaic Commentary to the Book of Genesis: A New American Translation (3 vols.; Brown Judaic Studies 104-06; Atlanta: Scholars Press, 1985. See Pseudo-Philo, Biblical Antiquities, 32:1-2, See also Kugel who speaks of the angel's jealousy of Abraham (Traditions, 301). 
Jubilees that God is not ignorant" and knows of Abraham's faithfulness since the original account opens up the possibility that God possesses incomplete knowledge. ${ }^{219}$ Therefore adding the Prince of Mastema not only removes culpability from God, but the insertion also safeguards the omniscience of God by making Abraham prove his faithfulness to the Prince. ${ }^{220}$ An omniscient God possessing knowledge of Abraham's faithfulness would have no need to test Abraham without the Prince's accusation. ${ }^{221}$ The element of testing also links the stories of Abraham and Job and may help to date the stories. Many scholars view tests for the entire nation of Israel (Deut 13:3; Judg 2:22) as "comparatively older" than these individual tests. ${ }^{222}$ However, the biblical tests of Job and Abraham differ greatly. The reader of Genesis 22 learns about Abraham's test from the narrator, whereas the narrator uses dialogues between God and ha-Satan to communicate the impetus behind Job's trial to the reader. This use of dialogue may reveal a later dating for Job. Berlin's contrast between information conveyed via the narrator in Kings and via dialogue in Ruth provides support for this possibility. Later

\footnotetext{
${ }^{219}$ Ruiten, "Abraham, Job," 84. See also Walter Brueggemann who challenges God's omniscience in the story, arguing that God does not know what Abraham will do (Genesis: A Bible Commentary for Teaching and Preaching, [Int; Atlanta: John Knox, 1982], 187). Other texts show no desire to protect God's omniscience. Targum Neofiti is unconcerned with the question of omniscience because God already knew what Abraham would do. The Targum shifts its attention to Abraham's ability to keep the Torah in spite of the fact that God had not given the Torah. See also Frédéric Manns, ed., The Sacrifice of Isaac in Three Monotheistic Religions: Proceedings of a Symposium on the Interpretation of the Scriptures held in Jerusalem, March 16-17, 1995 (Jerusalem: Franciscan Printing Press, 1995), 188-190.

${ }^{220}$ According to Kugel, God's words in Gen 22:12 “'Now I know' seems to imply 'I did not know before" (Traditions, 302). Kugel points to several translations and interpretations that attempt to protect God's omniscience, including Jubilees 18:16, Pseudo-Philo, Biblical Antiquities 32:4, Peshitta (some versions) Gen 22:12, Genesis Rabbah 56:7, and Augustine, City of God 16.32 (Traditions, 302-03).

${ }^{221}$ For Gerhard von Rad's objections to the reinterpretation in Jubilees and his discussion of other interpretations of the text, see Das Opfer des Abraham mit Texten von Luther, Kierkegaard, Kolakowski und Bildern von Rembrandt (Kaiser Tractate 6; München: C. Kaiser, 1971), 38-39.

${ }^{222} \mathrm{Rad}$, Genesis, 239-40. See also Ruiten who believes that "the test of the individual is a relatively late development in the religion of Israel and early Judaism" ("Abraham, Job," 61-62).
} 
narrators may have acted obtrusively by placing key comments in the mouths of characters as well as by introducing new characters.

Targum Jonathan (Genesis 22) uses dialogue to create a new scenario that explains why God tested Abraham. The text features a conversation between Ishmael and Isaac, with each proclaiming himself Abraham's rightful heir. Ishmael states that he could have refused circumcision at the age of thirteen while an eight day old Isaac had no choice in the matter. Isaac responds, "Behold, today, I am thirty seven years old, and if the Holy One, blessed be He, were to ask all my members, I would not refuse."223 These words prompt God to test Abraham. ${ }^{224}$

Even later interpretations and re-imaginings of the story reveal efforts to exonerate God. Louis A. Berman notes that 'the phrase 'God spoke to Abraham' may be taken to mean 'Abraham felt with all his heart that this is what God wanted him to do.",225 Although Maimonides deserves credit for the idea, Martin Buber and Christian scholars perpetuated the philosopher's endeavor to protect God. ${ }^{226}$

Berman also points to other problems that arise from re-envisioning the story, problems that challenge narrative artistry because of obtrusiveness: "If Genesis 22 is such

${ }^{223}$ See Manns, The Sacrifice of Isaac, 185.

${ }^{224}$ For more on Isaac being tested and his willing response, see 4 Macc. 7:12-14; 13:12; $16: 20$ and Pseudo Philo, Biblical Antiquities 32:2-3 and Josephus, Jewish Antiquities 1:232 and 1 Clement 31:2-4.

${ }^{225}$ Berman, The Akedah, 57.

${ }^{226}$ See Moses Maimonides, Crisis and Leadership: Epistles of Maimonides (trans. Abraham Halking; Discussions by David Hartman; Philadelphia: JPS, 1985); and Martin Buber, "Le Sacrifice d'Isaac," Dieu Vivant 22 (1952): 69-76. See also Ina Willi-Plein who notes that Christians will also have a problem with God's test or temptation of Abraham due to the description of a deity who neither tempts nor is tempted in Jas 1:13, but she ultimately finds no discrepancies between the two texts ("Die Versuch steht am Schluss. Inhalt und Ziel der Versuchung Abrahams nach der Erzählung in Gen 22” TZ 48 [1992]: 100-08). 
an artistic masterpiece, why has the narrative been supplemented with so many legends and rabbinical midrashim, which fills in all the gaps and thus undoes the artistic ambiguity critics find so enchanting?"227 Berman's comments reveal that excessive obtrusions diminish narrative artistry, and they reflect a wish for greater obtrusiveness among later interpreters of the Aqedah.

This desire for more obtrusiveness in later Jewish and Christian writings and in biblical scholarship raises questions about whether Gen 22:1 represents general omniscience or obtrusiveness. ${ }^{228}$ Perhaps the narrator failed to cross the boundary between the two; for even in the attempt to obtrude, the narrator still held onto some of the characteristic reticence often displayed in the biblical text. On the other hand, the narrator's degree of obtrusiveness may directly relate to the narrator's historical context. Although locating this narrator in history may prove difficult, later narrators utilized literary devices in obtrusions, such as creating new dialogues or utilizing otherworldly characters in order to protect the divine. In spite of being less intrusive than later interpreters of the story, the narrator of Gen 22 acts obtrusively by intervening at the beginning of the text with the specific goal of influencing reader response.

\footnotetext{
${ }^{227}$ Berman, The Akedah, 73.

${ }^{228}$ For more on the Aqedah in Jewish and Christian tradition, see Lukas Kundert, Die Opferung/Bindung Isaaks (2 vols.; WMANT 78-79; Vol. 1: Gen 22,1-19 im Alten Testament, im Frühjudentum und im Neuen Testament; Vol. 2: Gen 22, 1-19 im frühen rabbinischen Texten; Neukirchen-Vluyn: Neukirchener Verl, 1998).
} 


\section{Interpreter's Choice}

In defining Gen 22:1 as an obtrusion, I recognize the difficulties involved in forming a methodology to deal with the anomalous actions of the laconic narrator. Since intrusiveness in biblical narrative ranges from subtle comments to major intrusions, interpreters and translators may have their own reasons for categorizing a narrative remark as an obtrusion. Even individual words may prepare the reader for later developments through the use of ostensibly unimportant information, such as when the narrator describes a matriarch as "barren." ${ }^{229}$ Nahum Sarna defines such words and phrases as the "narrative technique of slipping in seemingly innocent phrases that are portentous of later developments.” Although not necessarily obtrusions, such words reveal the narrator's inconspicuous placement of information. Since the narrator rarely provides this knowledge, readers may sometimes pass over narrative information. Considering the subtlety and laconic nature of the narrator, individual interpreters and translators may have specific reasons for characterizing a narrative comment as an obtrusion-reasons that may exceed the scope of this methodology.

The subtle way in which the narrator introduces ideas and describes characters necessitates close readings of the text. Bar-Efrat argues that "the method of the biblical narrator requires a constant mental effort on the part of the reader, involving careful thought and attention to every detail of the narrative." ${ }^{230}$ Here, Bar-Efrat reveals another important connection between narrative criticism and reader response. Determining the narrator's view of a character also requires careful reading as Bar-Efrat states, "It is true

${ }^{229}$ See Sarna, “Anticipatory Use,” 215. See also Rad, Genesis, 154.

${ }^{230}$ Bar-Efrat, Narrative Art, 45. 
that their stance [toward a character] is indicated by implication rather than explicitly or obtrusively, but this method is no less efficacious than the direct and obvious one. On the contrary, just because it is not conspicuous and functions covertly, it tends to be more effective in transmitting narrators' values to the readers." ${ }^{231}$ Again, the laconic narrator gains the trust of the reader and effectively and subtlety shapes the way the reader views the text.

\section{Summary}

After examining this methodology, I have reached the following conclusions:

(1) Whether a comment represents general omniscience or obtrusiveness relates to the type of knowledge being shared. Asides, historical information, and essential information are often the narrator's endeavors to assist reader understanding through general omniscience. Obtrusions may represent non-essential narrative comments that could be omitted from a story, or they may represent essential comments that are intrusive based on their location and the narrator's intent to intervene. In both cases, they reveal active attempts by the narrator to influence reader response.

(2) Obtrusions often employ divine causality, but they invoke God in at least two different ways. They attempt to exonerate God or another character. At other times, divine causality is used to explain or change a situation because God is the ultimate personality in the narrative.

(3) Narrators decide to share information with readers based on their anticipation of reader assumptions and implied questions, the frame of the original story, and the reframing of the story in a larger context.

(4) The location of an obtrusion relates to the way the narrator frames or reframes a story. The placement of the obtrusion is also connected to time.

(5) A gap may be a preexisting condition of an original story, or it may arise when the narrator reframes a narrative. The narrator may not notice such gap, or the narrator may choose to allow it to remain in the story.

${ }^{231}$ Bar-Efrat, Narrative Art, 33. 
(6) Reception history identifies various types of readers who have had a problem with a narrative obtrusion. Some examples may come from early Jewish and Christian writings while others may reveal the difficulties modern scholarship faces in discussing difficult passages.

(7) I cannot assume that this methodology will be able to cover every potential obtrusion. My methodology merely serves as a guide for interpreters who may add their own unique concerns and ideas to this system. 


\section{CHAPTER III}

\section{THE NARRATIVE OBTRUSION OF JUDGES 14:4}

The narrator's foray into the story of Samson in Judg 14:4 is a good example of narrative obtrusion in the Hebrew Bible because the verse breaks frame at a key structuring point in the book of Judges and contains examples of both omniscience and obtrusiveness. The opening verses of chapter 14 recount Samson's desire to marry a Timnite woman. When his parents object, Samson proclaims that this girl is the only one for him. In spite of the fact that his parents have previously received divine revelations, such as an angel foretelling Samson's birth to them, they lack an important piece of information for understanding their son's motivations. The narrator interrupts the scene to explain Samson's choice of a bride by writing, "But his father and his mother did not know that it was of the Lord. He was seeking an occasion/pretext against the Philistines, for at that time the Philistines were ruling over Israel."232 While the storyteller communicates omniscient information in $14: 4 \mathrm{~b}$, the commentary in 14:4a is an obtrusion in which the narrator breaks the frame of the story to add the theme of divine control into the text. This intrusion, however, raises several additional questions for the reader as the history of interpretation reveals.

To recognize the implications of the obtrusive narrator, I examine the break frame of Judg 14:4 by showing both what the interruption adds and takes away from the story in

\footnotetext{
${ }^{232}$ Unless otherwise noted, all translations are my own. I have deliberately placed the terms "occasion" and "pretext" side-by-side since some of the commentators I will discuss later make their case for which term they feel is more appropriate.
} 
terms of its characterization of Samson and Yahweh as well as its effect on reader response. I use Judg 14:4 to employ the methodology introduced in the previous chapter by distinguishing between general omniscience and obtrusiveness, by examining the reader's implied questions and assumptions, and by seeking to determine whether or not the comment is essential. Along the way, I highlight the troublesome nature of this verse in the history of interpretation and consider the possible motives of the narrator.

\section{Samson as an Interloper in Judges}

A number of reasons make the Samson saga optimal for studying narrative obtrusiveness and omniscience. As a succinct block of material set in the larger framework of the book of Judges, Judges 13-16 also makes up part of the Deuteronomistic History. The story lends itself to a study of omniscience because Samson's life and deeds revolve around acquiring and hiding knowledge. The narrator displays this command of omniscience by withholding or omitting information in the text.

In spite of the promising possibilities for studying omniscience and obtrusiveness, some scholars find the placement of the Samson story within Judges troublesome. Some even view Samson's saga as an obtrusion in the book of Judges as well as in the larger corpus of the Deuteronomistic History. Gregory Mobley recounts Martin Noth and Wolfgang Richter's misgivings about the text. He points out that Noth wavered between declaring Samson a part of the Deuteronomistic work or "a post-Deuteronomic interpolation." Noth based his claim on the list of judges from 1 Sam 12:1 that includes 
Jerubbaal, Barak, and Jepthah but fails to mention Samson. ${ }^{233}$ Similarly, Richter viewed the Samson saga as the final element added to the book Judges, even though he deemed the stories very old. ${ }^{234}$ Richter's analysis of the text opens up the possibility that the narrator reworked these stories to better incorporate them into the larger framework of Judges.

Cheryl Exum finds Samson's placement within this framework problematic because the narrator's characterization of Samson deviates from the profile of the other judges: "Neither judge nor military leader, he acts alone against the Philistines in what appear to be personal vendettas. Moreover, he does not succeed in delivering Israel from the Philistine oppression." ${ }^{235}$ Samson's unfulfilled potential arises early in the story when the angel of the Lord tells Samson's mother that her son will only begin to deliver Israel $(13: 5){ }^{236}$ But in spite of the possibility that Samson is a later addition whose characterization clashes with the portrait of the other judges, readers may ultimately

\footnotetext{
${ }^{233}$ Gregory Mobley, Samson and the Liminal Hero in the Ancient Near East (Library of Hebrew Bible/Old Testament Studies; New York: T \& T Clark, 2006), 3. See Martin Noth, The Deuteronomistic History $\left(2^{\text {nd }}\right.$ ed.; JSOTSup 15; Sheffield: JSOT Press, 1991); trans. of Überlieferungsgeschicthliche Studien I: die sammelnden und bearbeiten Geschichtswerke im Alten Testament (Halle [Saale] M. Niemeyer, 1943).

${ }^{234}$ Wolfgang Richter, Traditionsgeschichtliche Untersuchunge zum Richterbuch (Bonn: Peter Hanstein, 1963). See also Wolfgang Richer, Die Bearbeitung des "Retterbuches" in der deuteronomischen Epoch (Bonn: Peter Hanstein, 1964).

${ }^{235}$ Cheryl J. Exum, “Aspects of Symmetry and Balance in the Samson Saga," JSOT 19 (1981): 27-28, n. 15. For the idea that various traditions were placed together to create the Samson story, see Hartmut Gese, "Die ältere Simsonüberlieferung (Richter c. 14-15)," ZTK 82 (1985): 261-80.
}

${ }^{236}$ Mark Greene argues that readers will see the textual unity in the Deuteronomistic History and look to David as the leader who completes the mission that Samson began ("Enigma Variations: Aspects of the Samson Story Judges 13-16," VE 21 [1991]: 51-80). 
discover that his self-centered actions serve a greater purpose in the book, revealing artistry in the narrator's choice to include him. ${ }^{237}$

J. P. U. Lilley, however, argues that the obtrusive nature of the Samson story damaged narrative cohesiveness in the book of Judges: "the material concerning Samson has detracted from the main theme ... rather than illustrated it." ${ }^{238}$ According to Lilley, the addition of chapters 17-21, most specifically the stories of Micah and the Levite's concubine, remedied this problem. While other scholars have viewed these final chapters as an addendum to the book, Lilley sees them as narrative art, serving as a corrective measure for the broken frame created by the interloping strong man Samson. ${ }^{239}$

Contrary to Lilley, Timothy Crawford posits that the Samson story coheres to the larger framework of Judges and the Deuteronomistic History: "The book is shaped as part of a sequence. Its full meaning can only be determined by its context. Israel's inevitable but flawed journey toward kingship is a major issue of the Deuteronomistic History. The story of Samson comes in the midst of and is a part of this journey." 240 The Samson saga, therefore, offers scholars additional ways to examine the issue of textual unity.

\footnotetext{
${ }^{237}$ For more on Samson's individual quest for revenge as well the potential for the story's origins in the pre-state period with the final compilation occurring in the post-exilic period, see Renate Jost, "Der Gott Der Liebe, Der Gott Der Rache Oder: Simsons 'Rachegebet'” in Von der Wurzel getragen: Christliche feministiche Exegese in Auseinandersetzung mit Antijudaismus (ed. Luise Schottroff and Marie-Theres Wacker; Leiden; New York: E. J. Brill, 1996), 104-13. For another discussion of the story's origins, see Robert Triomphe, "Le Lion et le Miel," RHPR 62 (1982): 113-40.

${ }^{238}$ J. P. U. Lilley, “A Literary Appreciation of the Book of Judges,” TynBul 18 (1967): 94-102. Lilley also gives a brief overview of scholarship on the book of Judges and the various theories about authorship (94). He defines the "essence of literary talent" as an author's ability to envision "in his own mind the general idea and plan of a book" (95).

${ }^{239}$ See Arthur E. Cundall, Judges: An Introduction and Commentary (Vol. 7 of TOTC; Chicago: Intervarsity, 1968), 50.

${ }^{240}$ Timothy Crawford, "Reading Samson with the Dead," PRSt 35 (Fall 2008): 223-36. See also Roger Ryan who views "the Samson story—not as an intrusion into the book's structure, but —as part of the
} 


\section{Redefining Textual Unity}

Scholars often define textual unity or disunity through the polarizing aspects of narrative criticism and historical criticism, thus revealing the need for a middle ground in the discussion. A combination of the two methodologies allows for a more centered approach that considers individual texts and the ways they cohere to larger bodies of work. For example, scholars may examine the stories in the Samson saga individually, collectively, in relation to the book of Judges, and as part of the Deuteronomistic History. $^{241}$

Limiting the definition of text to the book of Judges reveals that other stories in Judges also seem out of place. In many ways, the story of Abimelech goes against the grain of the book. ${ }^{242}$ Abimelech arises, not as a deliverer, but as a usurper of the power his father Jerubbaal relinquished in favor of divine rule. Abimelech's reign reflects internal strife rather than the usual outside opposition. However, broadening the definition of text to include the entire Deuteronomistic History shows that the story of Abimelech illustrates one of the many ways the Deuteronomist wrestles with the issue of kingship.

\footnotetext{
Judges narrative in which it is set because he is Israel's next judge and deliverer" (Judges [ed. John Jarick; Readings: A New Biblical Commentary; Sheffield: Sheffield Phoenix, 2007], 105).

${ }^{241}$ Several authors discuss issues of textual unity in Judges, including Otto Eissfeldt, Die Quellen des Richterbuches (Leipzig: J. C. Hinrichs, 1925), 81-87; Greene, "Enigma Variations," 51-80; Edward L. Greenstein, "The Riddle of Samson," Proof 1 (1981): 237-60; Kenneth R. R. Gros Louis, "The Book of Judges," in Literary Interpretations of Biblical Narratives (ed. K. Gros Louis, J. Ackerman, T. Warshaw. Nashville: Abingdon, 1974), 141-62; Barry G. Webb, The Book of Judges: An Integrated Reading (JSOTSup 46; Sheffield: JSOT Press, 1987). Webb argues for textual unity even though reframing and reworking may have occurred: "The author of a narrative work may not be aware of all that it means, especially if he has not created it ex nihilo, but taken existing materials, or even an existing narrative, and modified them (or it) to make the work what it is now" (39).

${ }^{242}$ I discuss obtrusiveness and omniscience in the Abimelech story in chapter 4.
} 
While questions about kingship dominate much of the Deuteronomistic History, the narrator of Judges also had a larger framework of apostasy, subjugation, and deliverance in mind; but the narrator used specific frameworks and other narrative devices for individual stories. ${ }^{243}$ For example, the narrator limits use of the phrase "the Spirit of the Lord" to Othniel (3:10), Gideon (6:34), Jephthah (11:29), and Samson $(13: 25 ; 14: 6,19 ; 15: 14)$. Also, some judges have stories recounting their great deeds while others merely receive a footnote about their tenure. ${ }^{244}$ The narrator recognized the unique story of each judge but reframed these individual narratives to fit into the larger pattern.

Because of this larger pattern, readers recognize that connections exist between Samson and previous judges in spite of the fact that some scholars view the Samson saga as an intrusive element in the book of Judges. Greene discusses these connections, arguing that "the reader, before coming to chapters 13-16, has already been attuned to making links between stories, beyond the observation of the sin-cry-rescue pattern ... These links encourage the reader to cross-compare the events and characters in each story. The results of such a comparison are, however, left to the reader." 245 Nevetheless,

\footnotetext{
${ }^{243}$ The stories most likely had pre-existing frames that the narrator either left in the story or reworked, perhaps with a different purpose in mind.

${ }^{244}$ On two occasions the narrator shares historical information from an omniscient perspective to let us know that Samson ruled Israel for twenty years (15:20, 16:31b). Exum notes that the problem of these notes has not been solved. However, she wonders if they are "an indication that the Deuteronomistic historian was aware of the parallelism of the accounts and accordingly provided symmetrical notices about Samson's term of office as judge." In the end, she describes the narrator's "complex patterning" as "artistry" ("Symmetry," 9-10, 27-28, n. 15). See also J. Cheryl Exum, "Promise and Fulfillment: Narrative Art in Judges 13," JBL 99 (1980) 43-59.

${ }^{245}$ Greene, "Enigma," 56. See also Gros Louis who notes that "there is a remarkable coherence to these narratives; incidents and elements of each echo in all of the others" ("The Book of Judges," 157). Greene sees this coherence in the unusual weapons in Judges, "serving perhaps to reinforce the proposition that the
} 
the narrator may influence the reader by breaking patterns and breaking the frame of the story.

\section{An Intentional Gap}

Crawford illumines the uncharacteristic behavior of the Israelites at the beginning of the narrative, observing that they no longer entreat God when the Philistines come to power. ${ }^{246}$ Perhaps they remember God's emphatic promise not to deliver them in Judg 10:11-14. Nevertheless the omission of Israel's cry to God represents an intentional gap designed to let readers know the depths to which Israel had fallen. To create this gap, the narrator reworked the type scene of the barren woman. At first, Manoah's wife seems like the typical infertile woman of the biblical text, but neither she nor her husband plead with God for a child. While the narrator's reference to the lack of a child may have shown that the couple desired children, Greene thinks that the narrator's departure from the type scene fulfills a larger purpose:

This absence of national cry for deliverance is then mirrored by the absence of any recorded individual cry for deliverance from the shame of barrenness by either Manoah or his wife . . . absence of 'cry' at the individual and national level not only suggests a parallel between the two and draws attention to the extraordinary grace of Yahweh who intervenes, unbidden, to save his people, but also establishes the expectation that the solution to both problems will be related. ${ }^{247}$

\footnotetext{
Philistines' monopoly on iron posed no obstacle to the purposes of Yahweh" ("Enigma Variations," 68). For a discussion of Samson's natural weapons versus the manufactured weapons of the Philistines, see Hermann Gunkel, "Simson," in Reden und Aufsätze (Göttingen: Vandenhoeck \& Ruprecht, 1913), 46. 
The narrator skillfully created this parallel, forging a significant connection between the nation and Samson by making Samson the only Israelite who cries out to God. The Samson story diverges from other accounts of the judges because the narrator deviates from the sin-cry-rescue pattern and the type scene of the barren women in order to reinforce the fact that Israel no longer cried out to God. ${ }^{248}$

Barry G. Webb credits the narrator for setting up this scenario in the two stories that precede Samson: "In the Gideon and Jephthah narratives . . the practice of appealing to Yahweh comes under close scrutiny and the apparent connection between Israel's call and Yahweh's saving intervention in the earlier episodes is broken. Israel neither deserves (6.7-10) nor influences (10.10-16) Yahweh's intervention to rescue it. In the Samson episode the Israelites show little sign of even wanting to be rescued."249 While a narrator sometimes obtrudes to prove a point, the narrator may also omit information and influence reader response through a gap. ${ }^{250}$ The narrator uses Samson to restore the motif of crying out to God. Samson cries out to God for water at the point of death and prays for vengeance on the Philistines before he dies. ${ }^{251}$ Despite his shortcomings and the tendency of scholars to criticize him for his personal vendetta

\footnotetext{
${ }^{248}$ Samson also differs from other judges because they came to power as adults; whereas, God "preselected" Samson to deliver Israel before his conception (Gros Louis, "The Book of Judges," 158). Sometimes scholars recognize large connections in the Samson story. For a discussion of Samson's connection to Jacob's proclamation of Dan governing Israel, see Roland Goetschel, "Samson Messie chez R. Șadoq Ha-Kohen,” in Mélanges André Neher (Paris: Maisonneuve, 1975), 397-406.

${ }^{249}$ Webb, The Book of Judges, 163.

${ }^{250}$ Gaps may also be used as a point of emphasis. Chapters 14-15 focus heavily on the razor while ignoring other parts of the Nazirite vow (Greene, "Enigma Variations," 57-58). For more on being a Nazirite, see Fred Blumenthal, "Samson and Samuel: Two Styles of Leadership" JBQ 33 (2005): 108-12. For historical critical discussion of the issue, see James A. Wharton, "The Secret of Yahweh: Story and Affirmation in Judges 13-16," Int 27 (1973): 48-66.

${ }^{251}$ Webb, The Book of Judges, 163.
} 
against the Philistines, Samson cries to God and fights the enemy while the other Israelites remain silent and complacent.

Samson's flaws cannot be ignored. The narrator artistically weaves his story through the use of symmetry and, as a result, may obscure obtrusions. The symmetry appears in chapters 14-15 when a parental figure prevents or attempts to prevent Samson's contact with the Timnite. In chapter 14, Samson's parents unsuccessfully object to Samson's proposed exogamous union. In chapter 15, the Timnite's father denies Samson access to his daughter because he has given her to someone else. ${ }^{252}$ Due to such symmetry and other forms of congruity within texts, readers may gloss over obtrusions, appreciating the skillfulness of the narrator as they read about an imperfect Samson.

Perhaps readers also fail to recognize obtrusions because the narrator's omniscient perspective engenders their trust, and they enjoy envisioning the story from a vantage point in which they possess knowledge unavailable to the story's characters. Therefore readers may accept the narrator's comment in Judg 14:4 as helpful information. When Samson desires the Timnite, the narrator interrupts the story to explain that Samson's yearning is "of the Lord. He was seeking an occasion/pretext against the Philistines." This break frame provides the reader with knowledge that Samson's parents lack. Indeed, Samson himself may be unaware of Yahweh's purpose. The narrator manipulates the reader by sharing information. This sharing of knowledge aids the narrator in gaining and maintaining the reader's trust.

\footnotetext{
${ }^{252}$ Exum, "Symmetry," 16.
} 


\section{The Elusiveness of Knowledge}

In addition to sharing information with the reader, the omniscient narrator controls the knowledge that the story's characters possess. E. John Hamlin describes the book of Judges as "a lively human story ... of the mysterious workings of God in ways unrecognized by his own people (13:16; 14:4)."253 The Samson saga begins with God imparting knowledge to Manoah and his wife. In chapter 13, an angel breaks the divine silence that occurred in response to Israelite apostasy in chapter 10. The angel informs Samson's parents about the birth of a son who will begin to deliver Israel.

The narrator presents Samson's father Manoah as a character who wavers between lacking or possessing knowledge. At first, he fails to identify the man who appeared to his wife as a messenger of Yahweh. ${ }^{254}$ Later in the story, the narrator uses an omniscient comment to describe Manoah's inner thoughts to show how he finally recognized the true identity of the messenger (13:21). For Exum, this scene illustrates that "in the Samson saga, knowledge is elusive. The motif of knowing and not knowing draws attention to the mysterious ways of Yhwh, who works for Israel's benefit through and even in spite of the human participants with their limited vision." 255 This knowledge may remain elusive to the reader if the narrator chooses not to reveal it; but by sharing information, the narrator creates a bond of trust with the reader.

\footnotetext{
${ }^{253}$ E. John Hamlin, At Risk in the Promised Land: A Commentary on the Book of Judges (ed. F. C. Holmgren and G. A. F. Knight; ITC; Grand Rapids, Mi.: Wm B. Eerdmans, 1990), 126.

${ }^{254}$ Note the difference in the way the narrator describes the figure as "the angel of the Lord" $(13: 3,9,15$, $17,21)$ and the way Manoah and his wife describe him as "a man of God" or "the man who came to me" $(13: 6,8,10)$.

${ }^{255}$ Exum, "Symmetry," 27, n. 13.
} 
Carolyn Pressler believes that the narrator heightens tension by making Samson's parent's knowledgeable in some instances and clueless in others. She argues that the contrast between possessing and lacking knowledge that begins in chapter 13 becomes more pronounced in chapter 14. Of all of the concealed information, the most hidden reality lies in the fact that God is secretly at work in Samson's escapades."256 Although the narrator shares this significant information with the reader, both God and Samson hide information from Samson's parents. Samson will avoid telling them where he found honey, and God will no longer update them on the divine plan.

The narrator elevates the reader above the characters by telling them about God's hidden purpose in Samson's choice of a bride. Yair Zakovitch describes Samson's upcoming marriage to the Timnite as a difficult theological test for the editor of the book of Judges ${ }^{257}$ Since the narrator presented Samson as the next deliverer for Israel, readers may have wondered why they see the hero cavorting with the Philistines; and the narrator addresses this question with an obtrusion. While the narrator may have hoped to protect the character of Samson or at least place his actions under divine control, his comment may have raised more questions for the reader. Samson's subsequent liaisons, with a prostitute in Gaza and with Delilah, make this information seem unessential since the narrator offers no inkling of divine interference in these instances. ${ }^{258}$ The character has a proclivity for socially unacceptable women that the narrator only explains in 14:4, an

\footnotetext{
${ }^{256}$ Carolyn Pressler, Joshua, Judges, and Ruth (ed. P. D. Miller and D. L. Bartlett; Westminster Bible Companion; Louisville, Ky.: Westminster John Knox, 2002), 216. For more on Samson's riddle, see Klaus Koenen, “'Wem ist Weh? Wem ist Ach? ... Wer hat trübe Augen' Zur Funktion von Rätselfragen im Alten Testament," BN 94 (1998): 79-86.

${ }^{257}$ Yair Zakovitch, Haye Shimshon (Jerusalem: Magness, 1982), 88.

${ }^{258}$ I consider this issue more fully later in this chapter when I discuss deleting the obtrusion.
} 
intrusion that increases the likelihood that the narrator has crossed the threshold of omniscience into obtrusiveness.

\section{General Omniscience and Obtrusiveness}

A look at the whole verse reveals both an example of obtrusiveness and general omniscience in the same passage: "But his father and his mother did not know that it was of the Lord. He was seeking an occasion/pretext against the Philistines, for at that time the Philistines were ruling over Israel." The first part of the verse fits the obtrusive profile since the narrator tries to remove questions from the reader's mind by intruding with nonessential information. In contrast, Judg 14:4b ("for at that time the Philistines were ruling over Israel") contains essential information in which the narrator shares historical knowledge with the reader without attempting to influence reader response. ${ }^{259}$ In $14: 4 a$ the narrator writes, not merely to teach a history lesson, but to encourage readers to accept a particular version of the story and of divine action within that story. While I characterize $14: 4 \mathrm{~b}$ as a narrative aside, I call 14:4a an obtrusion because the term more fully reflects the intrusion of the narrator. The storyteller has taken on a more substantial role than that of omniscient narrator, becoming a commentator on the story.

Similar to Judg 14:4b, Judg 16:20 is an example of an omniscient but unobtrusive comment in the Samson saga. This verse recounts the final time Delilah shouts the

\footnotetext{
${ }^{259}$ This information is repeated when the Israelites confront Samson in 15:11, reinforcing the fact that 14:4b represents omniscient knowledge since the narrator shares information with the reader that is obvious to all the participants in the story. The Israelites present this information presented to Samson in the form of a question, "Don't you know that the Philistines rule over us?" Webb argues that "Samson knows this, but what neither he nor his questioners know that Yahweh is seeking an occasion against the Philistines through Samson" (The Book of Judges, 173). The obtrusive nature of 14:4a is highlighted by the fact that perhaps even Samson lacks knowledge of the Lord's actions.
} 
duplicitous warning, "The Philistines are upon you!" Not knowing that his hair has been cut, Samson assumes the story will continue its repetitive cycle. Possessing intimate knowledge of the character, "the narrator affords us fleeting entry into Samson's inmost thoughts" by stating, "And he awoke from his sleep and thought, 'I will go out just as I have done before, and I will shake myself." ${ }^{260}$ The narrator advances the plot by sharing Samson's thoughts and also continues the theme of elusive knowledge, ending the tragic account by stating: "but he did not know that the Lord had left him." The narrator's comment in Judg 16:20 stands in stark contrast with the intrusion in 14:4a. Both verses reveal the type of hidden knowledge that displays the narrator's omniscience, but the narrative aside in 16:20 allows the narrator to share secret information with the reader to explain the situation. In contrast, the break frame of 14:4a reveals the narrator's desire to influence the way the reader comprehends the text—explaining away any troublesome questions about Samson's interest in the Timnite before the reader has a chance to formulate them.

Narrative Motive, Reframing, and Characterization

Since the narrator tries to prevent the reader from asking certain questions, an exploration of the narrator's motives is in order. Mark Brettler interprets the story, not through the obtrusion of 14:4a, but by looking at the way the Wisdom tradition could have reframed a popular story like Samson. Brettler finds the Samson stories ripe with possibility for the Wisdom school since they deal with foreign women, divine causality,

${ }^{260}$ James L. Crenshaw, Samson: A Secret Betrayed, a Vow Ignored (Atlanta: John Knox, 1978), 69. 
riddles, revenge, and the treatment of parents. ${ }^{261}$ Although I find flaws in Brettler's final analysis, his position deserves consideration since his argument deals with the reframing of stories, makes 14:4a an unessential comment, and highlights the mistakes that arise from mischaracterizing a figure in a narrative.

Brettler speculates that the Wisdom school reframed Judges 14-15: "I imagine that the author of the Judges material, like the author of the Job framework, knew traditional stories about his hero. (Ezekiel 14:14, 20 indicates that Job was widely known.) He took these stories and re-framed them into his own world-view to express the lessons that he wanted to illustrate."262 Samson may have seemed a crude hero to set forth as a paradigm for wisdom, but Brettler postulates that the wisdom narrators sanctified him for their own purpose.

A prevalent theme in the Wisdom tradition expresses the idea that a divine purpose lies behind every encounter: "This idea, that YHWH is really in control, even when people appear to be acting of their own volition, characterizes wisdom literature. ${ }^{, 263}$ Brettler contends that the Wisdom tradition influenced the Joseph story, and Gen 50:20 provides support for his proposal. ${ }^{264}$ After suffering through slavery, false accusation, and imprisonment, Joseph tells his brothers that a divine purpose lay behind

\footnotetext{
${ }^{261}$ Mark Zvi Brettler, The Book of Judges (ed. Keith Whitelam; Old Testament Readings; New York: Routledge, 2002), 53-54.

${ }^{262}$ Brettler, The Book of Judges, 53. In spite of Brettler's reference to Ezekiel's knowledge of Job, we do not know what traditional stories the prophet may have known.

${ }^{263}$ Brettler, The Book of Judges, 51.

${ }^{264}$ For another connection between the stories of Joseph and Samson, particularly Gen 50:20 and Judg 14:4, see Leslie Hoppe, Joshua, Judges (vol. 5 of Old Testament Message; ed. C. Stuhlmueller and M. McNamara; Wilmington, De: Michael Glazier, 1982), 183.
} 
their actions: "Besides, although you intended me harm, God intended it for good, so as to bring about the present result, the survival of many people" (TNK).

Although potential connections between Samson and Joseph exist, Brettler's attempts to tie Samson to the Wisdom tradition weaken his argument. Possible parallels focusing on riddles and retribution are, at best, circumstantial evidence. ${ }^{265}$ Moreover, Samson hardly reflects the "family values" of the Wisdom tradition when his affections for the Timnite cause him to disregard the objections of his parents.

Brettler's thesis also suffers when he associates the Timnite woman with the profile of the foreign woman that wisdom texts so often deride. ${ }^{266}$ While Brettler deems Yahweh responsible for Samson's attraction to the Timnite, he sees the Philistine as a seductive woman who has bewitched Samson with her feminine wiles: "Perhaps the anonymity of the woman ... in distinction to Delilah in chapter 16 , helps to equate her with the anonymous, archetypal foreigner . . of Proverbs 1-9. In fact, the Timnite woman is like the woman of Qoh 7:26, created especially to ensnare men."267 The Timnite, however, falls well short of the depiction of the foreign woman in wisdom literature. Caught in the middle of the animosity between Samson and her people, her unabated weeping — not her charm or powers of seduction—finally convinces Samson to tell her the answer to the riddle. She suffers throughout the text, losing the happiness of her wedding feast to a ridiculous quarrel and finally her life to the beginnings of an

\footnotetext{
${ }^{265}$ Brettler, The Book of Judges, 29, 51.

${ }^{266}$ Brettler, The Book of Judges, 51.

${ }^{267}$ Brettler, The Book of Judges, 51. Later in the chapter, I discuss various possibilities for who causes the attraction between Samson and the Timnite.
} 
intense struggle between her ex-lover and her people. In the end, Brettler misapplies the type scene of the foreign woman to the Timnite and neglects to consider the narrator's characterization of her. The Timnite seems to be more a victim than a vixen. In fact, if any one "plays the harlot" in the story, it is Samson. ${ }^{268}$

Furthermore, if Judg 14-15 is a polemic against foreign women that 14:4a explains as being ordained by Yahweh, readers may wonder why this verse is necessary to accomplish the didactic function of warning unsuspecting young men of the dangers of such women. By omitting Judg 14:4a, readers may discover that the text teaches that a marriage to a foreign woman could create problems with one's parents, one's future inlaws, and the particular group to which the bride belongs. ${ }^{269}$ In short, Judg 14:4a plays no role in warning men about the perils traditionally associated with the foreign woman. The text may even vindicate the Timnite woman as a pawn in a man's game of riddles and one-upmanship.

Brettler's arguments demonstrate the problems that arise when scholars fail to give due consideration to issues of characterization in discussions of narrative motive. While his work on the reframing of stories presents opportunities for further exploration, scholars must exercise caution in order to avoid pigeon holing the biblical narrators. The same narrators who scholars have often characterized as elite male priests who

\footnotetext{
${ }^{268}$ Gros Louis, "The Book of Judges," 144. Although this reading of the narrative appears to exonerate the Timnite, I agree with Exum that the narrator suppresses some information about women in order to give them a particular role as is the case when the narrator does not even use the usual reference of intercourse before conception in the story of Samson's parents. In a story with so much eroticism, none is associated with Samson's mother (the good woman) but only appears in connection with bad women. (Was sagt das Richterbuch den Frauen? [SBS 169; Stuggart: Verlag Katholisches Bibelwerk, 1997], 47-48).

${ }^{269}$ Later in this chapter, I will further discuss the possibility of omitting 14:4a.
} 
championed patriarchy also told stories of powerful heroines such as Rebekah, Deborah, Jael, and Ruth.

\section{Divine Causality}

In spite of the problems with his analysis, Brettler's comments on divine causality merit consideration. A study of the biblical text shows that divine causality appears in texts outside of the Wisdom tradition and the Deuteronomistic History. The phrase מיהוה, which appears in Judg 14:4, is used twice in Psalm 37 to express the idea of divine control. Verse 23 of the Psalm states "It is of the Lord that an individual's steps are established, and in his way he delights." Verse 39 of this Psalm reads, "The deliverance of the righteous is from the Lord, he is their refuge in the time of distress." Examples of this worldview occur in both poetry and narrative. In Genesis 24 Abraham sends his servant to find a bride for Isaac, and the servant recounts the signs that led him to choose Rebekah. The narrator uses the phrase מיהוה when Rebekah's father and brother respond to the servant. "Then Laban and Bethuel answered and said, 'The thing comes from the Lord. We are not able to speak unto you anything bad or good"' (Gen 24:50) This story presents the theme of divine providence in marriage with an emphasis on marrying a woman of one's own kindred who shows reverence to her father and brother, yet applying the wisdom label to this narrative seems unnecessary.

A search of the specific phrase כי מיהוה that appears in Judg 14:4, however, reveals a connection to the Deuteronomist. 1 Samuel 1:20 records the answer to Hannah's prayers, "And in due time, Hannah conceived and gave birth to a son. And she named him Samuel because she asked for him from the Lord." Here, the Lord shows divine 
power by healing barrenness. Adonijah uses the phrase in $1 \mathrm{Kgs} 2: 15$, where, in an attempt to find favor with Bathsheba, the usurper admits that Solomon did not steal the kingship from him: "'You know that the kingdom belonged to me, and all Israel set their faces on me to reign, but the kingship has turned about and belongs to my brother because it was of the Lord that it should belong to him."' Although different words could express the idea that something is "of the Lord," this phrase appears unique to the Deuteronomist, increasing the likelihood that the school intruded in 14:4a.

John Gray defines the verse as an "apologetic note by the Deuteronomic compiler, reconciling the tradition of Samson's affiance with the Philistines with that of his exploits against them as one of the champions of Israel."270 Although James D. Martin never specifically connects the verse to the Deuteronomist, his comments reflect the school's worldview: "This verse is probably a late editorial addition to the story, an attempt to reconcile Samson's behaviour with the idea that he was a person dedicated to the service of the LORD. Like 13:1, it again emphasizes the fact that all Samson stories are to be read as part of that history, which is, in its entirety, under God's control and guidance."271 Perhaps the key to understanding 14:4 lies in examining the verses as an "occasion" or "pretext" for Yahweh to attack the Philistines.

\footnotetext{
${ }^{270}$ John Gray, Joshua, Judges and Ruth, (NCB; London: Marshall Morgan \& Scott Publications Ltd., 1986), 348. C. F. Burney shows that readers may find something amiss with the passage. His comments also point out the problems of endless redaction: "The whole verse seems to have formed no part of the original narrative. The first half of the verse has a back reference to ch. 13, and was added, probably, by the author of that chapter $\left(\mathrm{J}^{2}\right)$ in explanation of the fact that an inspired Nazirite should have determined to contract such a marriage-alliance ... To the same hand, probably, belongs the reference to the Philistine domination (possibly derived from $15^{11}$ ), which would be superfluous if due to a later hand than $\mathrm{R}^{\mathrm{E} 2}$ in $13^{\mathrm{bb}}$, or even $\mathrm{R}^{\mathrm{JE}}$ in $13^{\mathrm{sb}}$, (The Book of Judges: With Introduction and Notes $2^{\mathrm{nd}}$ edition [London: Rivingtons, 1930], 357).

${ }^{271}$ James D. Martin, The Book of Judges, (ed. P. R. Ackroyd, A. R. C. Leaney, J. W. Packer; CBC; London: Cambridge University Press, 1975), 161.
} 
In Judg 14:4, תאנה is a hapax legomenon rendered "opportunity, i.e. ground of quarrel." 272 The verb comes from the root wich means "be opportune, meet, encounter opportunely." Scholars translate the parallel word in Arabic as "the right time is come" or "it is come to the right time" or "to maturity" or "is opportune."273 Examining uses of this root throughout the Hebrew Bible offers some clue as to how ancient readers understood the word.

In Ex 21:13, the Piel Perfect form of the verb refers to accidental death. NRSV renders this form "an act of God." Since מקרה which refers to "chance" is not used, the idea that God is responsible for accidental death may be even stronger. With its connotations of divine control, this root may show that, unbeknownst to Samson, Yahweh attracts him to the Timnite in order to start a conflict. ${ }^{274}$

Prov 12:21 may express a similar idea. The verse uses the Pual form of waich means "to be allowed to meet, to be sent." NRSV renders the verse "No harm comes to the righteous but the wicked are filled with trouble." Similarly, Ps 91:10 states that "no evil will come upon you" (NRSV). Considering Judg 14:4 in light of these verses may reveal that Yahweh intends to bring harm upon the Philistines through Samson.

A word from the same root may even tie sexual desire to this opportunity for vengeance. Jer 2:24 employs the verb תאנתה to talk about the mating of donkeys. "Or like a wild ass used to the desert, Sniffing the wind in her eagerness, Whose passion none can restrain, None that seek her need grow weary -- In her season, they'll find her!" (TNK).

\footnotetext{
${ }^{272}$ BDB, “תאנה," 58.

273 BDB, “אנה," 58.

${ }^{274}$ Later in the chapter, I will consider this theory more fully.
} 
BDB renders the word "occasion, time of copulation." 275 The sexual connotations of this word lead to one possible reason ancient readers and listeners found Samson's stories so inviting. Pressler writes, “The storytellers and compilers seem to relish Samson's audaciousness and physical and sexual prowess. The Samson story was not likely intended merely as a cautionary tale."276 The theologizing of the story did not complete remove these alluring elements.

In spite of the potential appeal for this interpretation, the hapax legomenon תאנתה may reveal a lack of sufficient evidence for these claims. Furthermore, additional instances of the root אנה deserve exploration. In 2 Kgs 5:7 the narrator uses a Hithpael participle, meaning "cause oneself to meet, seek occasion (=seek a quarrel with). ${ }^{, 277}$ In this verse, the king of Israel believes that the king of Aram wishes to start a conflict with him by demanding that he cure Naaman's illness. Bewildered by what he sees as a pretext for battle, the king tears his clothes. Another alleged pretext occurs in 2 Sam 10 - even though the chapter lacks the root in question. At the beginning of the narrative, the advisors of the Ammonite King Hanun warn their leader to suspect treachery on King David's part. David has sent envoys to offer his condolences upon the death of Hanun's father, but Hanun's advisors view their presence as a pretext for espionage.

\footnotetext{
${ }^{275}$ BDB, “תא נת תק,"58.

${ }^{276}$ Pressler, Joshua, Judges, and Ruth, 224. Joseph Blenkinsopp states, "These stories in their original form were by no means religious in character ("Some Notes on the Saga of Samson and the Heroic Milieu," Scr 11 [1959]: 81-89). In fact, ancient readers and hearers may have liked the Samson story for the very same reasons modern readers like Cheryl Exum dislike the character: "I do not like what he does: beat up foreign men and chase foreign women" ("Lovis of Corinth's Blinded Samson," BibInt 6 [1998]: 410-25).

${ }^{277}$ BDB, אנה, 58.
} 
Pretexts create obtrusive possibilities for the narrator. In Gen 34, the narrator obtrudes to protect the reader from coming to an incorrect assumption about the sons of Jacob. The obtrusion appears when Jacob's sons discuss a marriage between Dinah and Shechem with the potential groom and his father. Angered by the fact that Shechem raped their sister Dinah, Jacob's sons used circumcision as a pretext for marriage. The narrator interrupts the flow of the narrative in verse 13 to inform the reader that the sons of Jacob were "speaking with guile because he had defiled their sister Dinah" (TNK). In reality, the sons of Jacob wanted the Shechem and his men to undergo circumcision in order to make them weak for battle. Shechem and his men had their own deceitful plans, hoping to acquire the wealth of Jacob's family through marriage. The narrator must include the obtrusion to balance the plotting of the Shechemites. After the Shechemites are circumcised, Simeon and Levi take advantage of their adversaries' inability to effectively defend themselves and kill all of the males. Without the obtrusion, readers would be shocked by the savagery. By obtruding, the narrator protects the characters by preventing readers from asking questions about why the sons of Jacob behaved so deceitfully and violently. ${ }^{278}$

\section{An Occasion or a Pretext?}

These considerations of pretexts in the Hebrew Bible necessarily lead to a discussion of the consequences of translating תאנה as "pretext" or "occasion" in Judg 14:4. The word "pretext" suggests that Yahweh instigates Samson's attraction to the

\footnotetext{
${ }^{278}$ The text wrestles with their savagery because their father condemns them for their act of violence. Their response ends the chapter as they ask their father if they should allow their sister to be treated like whore. Jacob, however, has the last word in Gen 49:5-7, cursing them for their anger, wrath, and lawless behavior.
} 
Timnite. On the other hand, the word "occasion" shows that Yahweh simply takes advantage of Samson's own desires in order to accomplish a divine purpose. The moral and theological implications of the translation raise the stakes in interpretation. Making Yahweh responsible for the physical attraction connects the Lord to the unorthodox practice of encouraging an exogamous marriage. This interpretation also creates a host of other problems as well, most specifically making the deity guilty of starting a war. Although the Hebrew Bible often speaks of the divine inciting war, some interpreters feel uncomfortable with the ethical implications of such actions. Therefore the following possibilities must be considered: (1) Yahweh is responsible for the attraction and is seeking an occasion for battle; (2) Samson is attracted to the Timnite woman, and henot Yahweh-is seeking a pretext for conflict; (3) Yahweh does not cause the attraction, but Samson's desire aligns with the deity's divine purpose; or (4) the narrator is using the idea of attraction to make the Samson story a microcosm of Israelite history in the book of Judges.

\section{Yahweh is Responsible}

James L. Crenshaw finds Yahweh responsible for Samson's longing for the Timnite woman: "The infatuation came from the Lord, who was eager to do battle with the Philistines." ${ }^{, 279}$ Crenshaw also states, "Samson's fondness for Philistine women was matched by a powerful dislike of Philistines in general on Yahweh's part. This divine hostility toward non-Israelites characterizes both the framework of the narrative and the

\footnotetext{
${ }^{279}$ Crenshaw, Samson, 69.
} 
individual stories. Indeed, the Lord appears as the one desiring to pick a fight with the Philistines (14:4), into whose hands he has given his wayward people (13:1)." 280 Samson's attraction to the Timnite becomes the way to deliver Israel from oppression. According to Carolyn Pressler, "Yahweh is thoroughly implicated in Samson's actions" as the divine matchmaker between Samson and the Timnite. ${ }^{281}$ She offers the following evidence: “That God is behind Samson's desire for the Timnite woman and all the ensuing events is explicated in Judg 13:25: 'The spirit of the Lord began to stir him. ...' The Hebrew verb translated 'stir,' meaning 'trouble' or 'drive,' is actually stronger than the English word would suggest. The spirit of Yahweh drove Samson."282 Pressler also depicts Yahweh as a mastermind, manipulating the marionette Samson through sexual desire: "God's agency in the story is hidden . . . An editorial comment (14:4) explains that Samson's parents did not know that his desire for the Timnite was from Yahweh, working behind the scenes to cause Samson to strike out against the Philistines. From all appearances, Samson himself remained unaware of God's role in the events." 283 The irony of this interpretation is that Yahweh makes Samson weak through sexual desire to provide him an occasion to display his God given strength.

\footnotetext{
${ }^{280}$ Crenshaw, Samson, 121. Although Samson faces the Philistines several times, Pnina Gallpaz-Feller connects Samson's request for vengeance on the Philistines in the temple of Dagon with Judg 14:4, but offers little additional commentary concerning this link. ("'Let My Soul Die with the Philistines' (Judges 16.30)" JSOT 30 [2006]: 315-25).

${ }^{281}$ Pressler, Joshua, Judges, and Ruth, 224.

${ }^{282}$ Pressler, Joshua, Judges, and Ruth, 216.

${ }^{283}$ Pressler, Joshua, Judges, and Ruth, 224. The connection to the Deuteronomist may reveal that these narrators reframed the story for their own purposes, but they did not completely remove some elements that went against their ideology. Perhaps their artistry is seen in the way in which they utilize the setting of Judges to show elements of sin and redemption through the use of a flawed character like Samson.
} 
In attributing the attraction to Yahweh, Exum explores the theme of possessing or lacking knowledge to prove her point. She observes symmetry in two of the narrator's notes that deal with characters lacking knowledge. She ties the Philistines' ignorance of the source of Samson's power in 16:9 to Samson's ignorance of his departed strength in 16:20. This knowledge themed symmetry extends from 14:4 to chapter 16: "The first and last references to knowing in chs.14-16 are related to Yhwh. This arrangement highlights the fact that Yhwh is behind Samson's escapades from the beginning, until the point when Samson is shaved."284 This overarching theme of the elusive nature of knowledge shapes the characters, calling for continued exploration of the motives of the characters and the narrator.

In discussing divine motive, Martin Emmrich refers to Yahweh as "the real instigator," pointing to textual evidence, such as Samson's eating of the honey in the carcass of the lion:

Thus, the eating of the honey involves a certain paradox. Although the act results in ceremonial impurity, Samson remains a נזיר. Yahweh's contribution in this episode is no less perplexing: Samson was not 'told' to eat the honey, but the entire situation is orchestrated by God. If this seems overstated, we should remember that even the judge's longing for the (ceremonially unclean) Timnite woman was - in a most puzzling way'from Yahweh' (cf. 14:4). Alongside Samson's callous disregard for

\footnotetext{
Yehezkel Kaufmann suggests that Samson did not consciously seek a pretext against the Philistines (Sefer Shofțim [Jerusalem: Kiryat-Sefer, 1962], 251. David Grossman raises the possibility "that the hero of our story is a man who does not know, and perhaps will never really understand, that God, even before his birth has nationalized his desires, his love, his entire emotional life." Grossman argues that Samson's feelings for the Timnite arise solely to fulfill the divine plan and do not come as a result of anything else- -"not love, or lust, or romance, and above all not free will." The laconic narrator often neglects to mention the emotions of characters, and Samson's emotions are of no concern to the narrator here (Lion's Honey: The Myth of Samson [trans. Stuart Schoffman; New York: Canongate, 2005], 39-41).

${ }^{284}$ Exum, "Symmetry," 9.
} 
ceremonial purity, then, Yahweh, too seems to operate outside of the scope of 'orthodox' expectations. ${ }^{285}$

Samson's cry to God for water out of the unclean jawbone of the donkey and God's answer may further confirm his disregard for the Torah (15:14-19). This text presents a deity willing to do anything to accomplish the purpose at hand-even going against norms prohibiting exogamous marriage.

The fallout from this construal of the evidence, however, goes beyond the choice of a marriage partner. A. Graeme Auld discusses the consequences of such hermeneutics. “it appears from verse 4 that Samson's God is responsible for his choice of activities and not just the superhuman strength to carry them out ... With models like this in what is Scripture to Jews and Christians alike, on what basis do we disapprove of Israeli or Palestinian murderous terror?"286 Although Auld ignores other wars incited by Yahweh, the ethical implications of this interpretation demand consideration. The text could implicate Yahweh in the conflict, but some readers may wonder if Yahweh truly controls Samson's actions. This question deserves consideration, not merely as an attempt to exonerate the deity, but to see if Yahweh is truly blameworthy.

\footnotetext{
${ }^{285}$ Emmrich, "The Symbolism," 72.

${ }^{286}$ A. Graeme Auld, Joshua, Judges, and Ruth (ed. John C. L. Gibson; Daily Study Bible; Philadelphia: Westminster, 1984), 210-21. For more on the ethical problems of "attributing human bigotry to God," see Wilda C. M. Gafney, “A Black Feminist Approach to Biblical Studies," Enc 67.4 (2006): 392-403. See also Exum who argues that "central to a reading of the Samson story as embodying a comic or classic vision is the acceptance of the narratorial point of view according to which God is controlling events according to a plan ... Samson is the instrument of a divine plan that, though unusual, does not appear inscrutable" ("Lovis," 414)..
} 
Samson is Seeking a Pretext for Conflict

Other scholars contend that Samson, not Yahweh, actively pursues a pretext for conflict. They base their reasoning on the antecedent of the pronoun in the verse, "he was seeking an occasion/pretext (emphasis mine)." Abraham Cohen offers the following argument:

Modern commentators define he as God; but it is contrary to Hebraic thought that God required an occasion in the circumstances here described ... making Samson the subject [is correct], but the phrase should be given its literal translation. The Philistines exercised dominion over Israel, and if Samson as the representative of his people attacked some of them, a counterattack would certainly be the sequel. The text states that it was ordained by God that Samson should suffer a personal affront at the hand of some Philistines upon whom he would take revenge as a wronged individual. $^{287}$

Therefore Yahweh is not responsible for the attraction, but welcomed the ensuing problems as an impetus for Samson to attack the Philistines.

Ambrose believed that Samson sought an occasion against the Philistines in order to create an opportunity to deliver the Israelites, but his interpretation sufferings from sanctifying Samson and ignoring characterization. ${ }^{288}$ Because Ambrose thought that Samson wanted to marry the Timnite to avoid lust, he describes Samson as less selfcentered and very concerned about spiritual matters. In many cases, the church fathers attempted to exonerate biblical characters with problematic lives lest readers of the text

\footnotetext{
${ }^{287}$ Abraham Cohen, Joshua-Judges: Hebrew Text \& English Translation with Introductions and Commentary, rev. and enl. ed., revised by A. J. Rosenberg, (New York: Soncino, 1982), 269. See also Howard Jacobson who suggests that Pseudo-Philo may have misunderstood the pronoun as well as Ambrose and Sifre to Numbers (A Commentary on Pseudo-Philo's Liber Antiquitarium Biblicarum with Latin Text and English Translation [2 vols.; AGJU 31; Leiden; New York: Brill, 1996], 993).

${ }^{288}$ Ambrose, using the LXX, Letter 35, The Fathers of the Church, A New Translation (Washington, D.C.: Catholic University of America Press, 1947-.), 26:179.
} 
follow in their footsteps or excuse their own poor behavior. ${ }^{289}$ The church fathers behave more obtrusively than the biblical narrator and reveal that biblical stories constantly undergo reframing.

Yairah Amit offers better support for viewing Samson as the one seeking the occasion by situating the story within the context of the book of Judges. She writes that "the shaping of the accounts of the judges' wars and of the personalities of the deliverers also serve the historian's purpose, by way of the signs or omens revealing God's action in history. The liberator is always a person who has been sent by God . . [Samson] is depicted as being one moved by the spirit of God, and exploits every pretext and opportunity (14.4) to act against the Philistines (14.19-16.30). ${ }^{290}$ According to Amit's reading, Samson is not the clueless muscle unwittingly working for the mastermind; but he embraces his role as a rabble rouser seeking trouble with the Philistines.

Roger Ryan argues that Samson "is able to devise his own unique methods of conflict with the Philistines" and purposefully seeks a conflict with them. ${ }^{291}$ According to Ryan, Samson displayed "cool effrontery to create a conflict opportunity by infiltrating Timnah and joining a Philistine family by marriage. ${ }^{292} \mathrm{He}$ further notes that Samson's parents "are unaware that Yahweh and Samson have begun to work together and that marriage is an opportunity to provoke the Philistines to do them harm." 293 Samson has

\footnotetext{
${ }^{289}$ Crawford, "Reading Samson,” 227.

${ }^{290}$ Yairah Amit, History and Ideology: An Introduction to Historiography in the Hebrew Bible (trans. Yael Lotan Sheffield: Sheffield Academic, 1999), 38.

${ }^{291}$ Ryan, Judges, 106.

${ }^{292}$ Ryan, Judges, 106.

${ }^{293}$ Ryan, Judges, 106.
} 
consciously teamed up with Yahweh. Yahweh provides Samson with strength to battle the Philistines, and Samson finds an excuse to use it. Judges 15:3 might support this premise. When Samson discovers that Timnite's father gave her to another man, he says, "Now the Philistines can have no claim against me for the harm I shall do them" (TNK). Since the Philistines have wronged Samson, he no longer needs to restrain himself but can display his strength.

Kenneth Gros Louis' proposal offers some middle ground between Yahweh or Samson seeking the occasion/pretext. Carefully considering the issue of characterization, he notes that Samson's “desire may be prompted by the Lord, as the narrative tells us, but he reveals himself as no diplomat in the discussion. ${ }^{, 294}$ Furthermore, ancient readers may not have cared which figure sought the occasion/pretext. ${ }^{295}$ Many modern readers, however, have this concern; but their motives may make their interpretations suspect. Most assign agency to Samson for the purpose of exculpating Yahweh. Although postulating that Samson actively looked for a pretext may have minor merits, this claim neglects to consider the characterization of Samson that Gros Louis figures into his argument.

Samson's Human Desires and Divine Purpose

No matter how readers or translators define the antecedent of the pronoun in Judg 14:4, Yahweh seems to stand behind the conflict, perhaps not as an inciter of war but as a

\footnotetext{
${ }^{294}$ Gros Louis, “The Book of Judges,” 158.

${ }^{295}$ For example, the Targums often make additions to the biblical text to explain issues; however, Targum Pseudo-Jonathan adds nothing new to 14:4 (Willem F. Smelik, The Targum of Judges [OtSt 36; Leiden: E. J. Brill, 1995], 570).
} 
deity concerned about the liberation of a people chosen for a higher purpose. Judges 10:10-16 characterizes Yahweh as a divine being who can neither bear to see the sin of the Israelites nor the oppression they face at the hands of others. Yahweh wants to help Israel. However, a question arises concerning whether or not Yahweh will go so far as to attract Samson to the Timnite, setting him off on a rampage against the Philistines. Perhaps Yahweh simply uses Samson's desires for the Lord's purposes. This possibility fits nicely into the main theme of the Deuteronomist in the book.

The theme focuses on the actions of individuals in pre-monarchic Israel and a generally unrecognized connection between Samson and this theme offers clues as to whether or not Yahweh creates Samson's attraction to the Timnite. A complete statement of the theme appears two times in Judges: "In those days there was no king in Israel. Everyone did what was right in his eyes" (17:6; 21:25; see also 18:1). Verse 3 of Judges 14 contains similar elements, but some translations obscure the link between Samson and this larger theme of the book of Judges. When Samson's parents take issue with his choice of a fiancée, TNK translates Samson's demands, "Get her for me, for she is the only one who pleases me." TNK's figurative translation overlooks possibilities that a literal rendering discloses. In a literal translation of Judg 14:3b, Samson says that, "she is the only one right in my eyes." 296 The statement in verse 3 connects Samson's story to the entire book and draws attention to the discordance of verse 4, revealing the damage to textual unity created by the obtrusion. ${ }^{297}$ Far from being the impetus behind the

\footnotetext{
${ }^{296}$ See also $14: 7$ where the phrase is repeated.

${ }^{297}$ Pseudo-Philo also blames Samson's troubles on his eyes. The text adds a good bit of dialogue to the narrative (Jacobsen, A Commentary, 165). For a discussion of Samson in the biblical text, Josephus, and Pseudo-Philo with consideration for what constitutes the final form of the text with regard to canonicity,
} 
attraction, the Lord may simply allow Samson to do whatever is right in his own eyes; and Yahweh works through the hero's shortcomings. The rabbis reached a similar conclusion after struggling with this passage. Caught between Samson's desire and Samson's duty, the rabbis ultimately decided that Samson acted out of his own free will. They believed, however, that the desires of Samson's eyes "lined up with the Lord's purpose ... [but] not due to Samson's faithfulness to Yahweh."298

K. Lawson Younger weighs in on the issue of Samson's free will and its connection to Yahweh's plan: "Yahweh's seeking does not imply that Yahweh incited Samson's desire for the Timnite woman. Rather, it suggests that Samson's irregular actions nevertheless accord with Yahweh's will."299 Josephus's rendering of the story falls in line with this reading. He explains Samson's relationship with the Timnite by replacing 14:4 with "God viewing the marriage as advantageous to the Hebrews." 300 Younger's interpretation, however, fails to ask how an individual chosen from birth for see Matthias Millard, "Samson und das Ende des Richterbuches": Ein Beispiel Einer Kanonexegese Zwischen Kompositions Und Wirkungsgeschtlicher Auslegung," in The Biblical Canons (ed. J. M. Auwers and H. J. De Jonge; Leuven: Leuven University Press, 2003), 227-34.

${ }^{298}$ Crawford, “Reading Samson, ” 230-31. Crawford offers a nice exploration of the rabbis' struggle with the text. He discusses Sotah 1:8-9 and I.1B-C. See Jacob Neusner and W. S. Green, eds. Dictionary of Judaism in the Biblical Period (Peabody: Hendrickson, 1999), 598. In spite of his agreement with this interpretation, Crawford believes that they could have made a better connection between Samson following his eyes when he saw the prostitute in Gaza. Nevertheless the rabbis connect Samson's fling in Gaza with his judgment there. See Midrash Numbers Rabbah (ed. and trans. H. Freedman and Maurice Simon; trans. J. J. Slotki; London: Soncino, 1983), 285, IX.24. For more on rabbinical views of Samson, see Rabbi Nosson, The Early Prophets with a Commentary Anthologized from the Rabbinic Writings (ed. Rabbi Meir Zlotowitz and Rabbi Feivel Wahl; 1st ed.; The Art Scroll Series; The Rubin Edition; Brooklyn: Mesorah Publications, 2000), 175, 201.

${ }^{299}$ K. Lawson Younger, Jr., Judges and Ruth (The NIV Application Commentary; Grand Rapids, Mi.: Zondervan, 2002), 301-02.

${ }^{300}$ Josephus, A. J. 5.286 [Begg]. See also Christopher T. Begg, "The End of Samson According to Josephus as Compared with the Bible, Pseudo-Philo, and Rabbinic Tradition," BN 131 (2006): 47-61. Begg discusses the reworking of the Samson story with both omissions and elaborations in Josephus. See also Mark Roncace, "Another Portrait of Josephus's Portrait of Samson," JSJ 35 (2004): 185-207; and Louis Feldman, “Josephus' Version of Samson,” JSJ 19 (1988): 171-214. 
the purpose of delivering Israel can have free will. His interpretation provides a comfortable answer to the question but prevents readers from wrestling with the perplexities of the text.

J. Clinton McCann, however, agrees with this interpretation and defends the actions of God by preferring the translation "occasion" over the term "pretext." McCann writes, 'The NRSV's 'pretext' is misleading. God does not need 'a pretext' to oppose Philistine oppression and injustice: God always opposes oppression. Rather, God needs 'an opportunity' or 'occasion' (NIV), which God finds in the gifted but all-too-human Samson. In short, 14:4 is an affirmation that God works incarnationally; God works with human resources at God's disposal, flawed as they may be in Samson's case." ${ }^{301}$ While this analysis seems to go too far in attempting to exonerate Yahweh, perhaps combining this proposal with an allegorical view of Samson will help to determine the extent to which Yahweh deserves blame for Samson's misdeeds.

\section{Samson as Allegory}

The flawed Samson displays the imperfections of the Israelite nation on an individual level. Yahweh's response to Samson's unacceptable behavior may represent divine attempts to return Samson to a more righteous path. Perhaps the narrator connects Yahweh with Samson's desire for the Timnite woman in order to show how the ensuing problems should have embittered Samson against the Philistines forever. However, Samson's love/hate relationship with the Philistines makes the plan turn out somewhat

${ }^{301}$ J. Clinton McCann, Judges (IBC; Louisville: John Knox, 1989), 102. 
differently. Therefore Samson becomes a typology the Deuteronomist uses to show the depths to which Israel had fallen.

Greenstein views Samson as the "epitomization of Israel” and wonders if the narrator has made him so "consciously or unconsciously."302 Tammi Schneider finds promise in this interpretation and ties it back to the change of pattern at the beginning of the story: "The deity needed to seek a pretext because the Israelites no longer fought Philistine control nor did they cry out to their deity." ${ }^{, 303}$ This characterization of Israel vis-à-vis Samson fits the Deuteronomistic theme of everyone acting according to his/her own desires.

Lillian Klein believes the problem has intensified because the Israelites have so easily assimilated into Philistine culture that they no longer wish to fight. Philistine oppression of Israel may have led to an unhealthy affection between the peoples, blurring the distinctive line that existed between enemies. Klein's characterization of Samson shows further connections between Israel and Samson. She describes "the strong man of the book" as the "weakest" judge because of his lusts: "And because his passions demand woman, Samson is at the mercy of womankind, a deplorable situation from the point-ofview of a patriarchal society. The last hope of Israel in the book of Judges is, then, a judge who chases women instead of enemies and who avenges only personal

\footnotetext{
${ }^{302}$ Greenstein, "The Riddle of Samson," 254-55.

${ }^{303}$ Tammi Schneider, Judges (Collegeville, Minn.: The Liturgical Press, 2000), 204.
} 
grievances. ${ }^{304}$ The Israelites are no different. Instead of pursuing their enemies, they are becoming far too enchanted with Philistine customs and culture.

Rather than calling for the eradication of the Philistines by sending Samson to fight, Yahweh may hope to avoid an Israelite genocide arising from assimilation. The true danger for Israel is not that some army will annihilate them but that the surrounding nations will consume them through assimilation. ${ }^{305}$ If the Israelites lose their distinctiveness, a people will cease to exist. Greene writes, "Samson is implicitly a type for the whole people. This identification of Samson with Israel's history, which is intrinsic to the narrator's presentation, makes the story a solemn warning against Israelite idolatry, a solemn summons to covenant holiness, and a solemn reminder that Israel is God's people. Israel, like Samson, did not choose to be set apart to God, but was chosen." ${ }^{306}$ Samson's struggles are Israel's struggles, and perhaps they both wrestle with their affections for the Philistines more than they battle the enemy.

The Joseph story also deals with the negative ramifications of the Israelites losing their identity through integrating into another culture. The divine will allows Joseph's brothers to sell him into slavery to prevent Israel from perishing from the earth. The greater danger, however, comes — not from the famine - but from Egyptian culture. The Israelites find Egypt so alluring that they are willing to remain as slaves. Yahweh

\footnotetext{
${ }^{304}$ Lillian R. Klein, The Triumph of Irony in the Book of Judges (Bible and Literature Series 14; Sheffield: Almond, 1988), 118.

${ }^{305}$ For more on Samson's liminal state between Israelite and Philistine, see Steven Weitzman, "The Samson Story as Border Fiction,” BibInt 10 (2002): 158-74.

${ }^{306}$ Greene, "Enigma Variations," 77.
} 
intervenes to remind Israel of its birthright. Perhaps the same thing happens in the Samson story with the main character representing the nation of Israel.

Klein makes the following comparisons between Samson and Israel. "That Samson, like Israel, has been dedicated to Yahweh from his conception makes his - and Israel's - blithe obliviousness to ethical values all the more poignant. Both Israel and Samson are nazirites in that they are dedicated to Yahweh from 'conception,' and both seem more concerned with personal gratification (including the pleasures of worldly values) than with the less tangible covenant." ${ }^{307}$ In essence, the Israelites are becoming more like Esau than Jacob. Content to satisfy their desires, the Israelites relinquish their birthright just as Samson squanders his gifts.

Michael Wilcock supports this argument by noting that "Samson's fraternizing with the enemy expresses in one individual what the attitude of the nation at large had become." ${ }^{308}$ Therefore Yahweh attempts to wake Samson/Israel from the attitude that has them sleeping comfortably in the lap of the enemy:

By the time of Samson, Israel had so accommodated herself to the world around her that ... she wants no rocking of the boat. Like Samson, she is willing, even eager, to marry into Philistine society. The force of 14:4 is that the two communities are so interlocked that even the Lord can find nothing to get hold of to prise them apart. He uses Samson's weakness, therefore, to bring about the relationship with this irresistible girl from which so much ill-feeling will flow, and in the process he gives Samson his supernatural strength and the first opportunities to use it. With the lion the young man discovers his gift, and with the slaughter at Ashkelon he finds its purpose. ${ }^{309}$

\footnotetext{
${ }^{307}$ Klein, The Triumph of Irony, 118. Here Klein accounts for the way Samson is different from other judges and just like Israel.

${ }^{308}$ Michael Wilcock, The Message of Judges (ed. J. A. Motyer; The Bible Speaks Today; Downers Grove, IL.: InterVarsity, 1992), 139.

${ }^{309}$ Wilcock, The Message of Judges, 139.
} 
Even with this purpose, Samson/Israel finds the attraction to the Philistines so difficult to break that the nation's deliverance begins but remains incomplete.

As a leader in Israel, Samson should have saved the people from the Philistines; but by doing what is right in his own eyes, he fails. Samson's impetus for fighting is not a love for deity or country but revenge fueled by lust. His divine mission should have driven him to deliver Israel from Philistine oppression, but Samson only fights when personally provoked. He never unites the people. In fact, the closest he comes to a tribal muster is when the Israelites tie him up and hand him over the Philistines (15:9-13). ${ }^{310}$ Samson's inability to take advantage of this potential rallying point makes him fall short of achieving complete deliverance for Israel.

Schneider offers a nice summary of the life of Samson. "He chose to marry, live with, fight, and die with the Philistines. His love of Philistines was precisely what the deity feared and why the Israelites were tested; to see if the Israelites would follow the nations surrounding them. ${ }^{311}$ Both Samson and Israel failed the test. Samson's repetitive cycle with Delilah mirrors the recurring patterns of the book of Judges: failing the test by edging closer and closer to the enemy. Just like Israel, Samson assumes that God will provide him with the strength for deliverance. Even though the Israelites have not cried out for deliverance in the Samson story, perhaps they are proceeding under the assumption that God will continue to assist them. Like Samson, the Israelites face the danger that they will arise to do as they have done before, only to discover that God is no

\footnotetext{
${ }^{310}$ The Israelites saw Samson as a threat to the peace they had achieved in the midst of oppression. For a discussion of the ways in which warriors endanger peace for other members of the society, see Bernard, Lang, "Von der Kriegerischen zur nativistischen Kultur. Das alte Israel im Lichte der Kulturanthropologie," EvT 68 (2008): 430-43.

${ }^{311}$ Schneider, Judges, 207-08.
} 
longer with them. Samson actually returns Israel to a better state since he cries out to God when he is in danger of dying of thirst and right before he dies in the Philistine temple. In the end, he falls into the hands of the enemy, prays for vengeance, and receives one last burst of strength.

\section{Reader Response}

In spite of the conclusion that Samson functions as a typology of Israel, the search for the narrative obtrusion's effect on reader response remains incomplete. Therefore I examine the effect of gaps on the reader and the possible expectations of the reader before considering two very important issues: (1) the potential effect on reader response from omitting 14:4; (2) reasons for keeping or omitting the verse.

\section{Gaps}

Meir Sternberg characterizes Judg 14:4 as a gap in knowledge that occurs due to the order in which the narrator conveys information. He writes, “The storyteller's withholding of information opens gaps, gaps produce discontinuity, and discontinuity breeds ambiguity." 312 Sternberg ties gaps to time, noting that some may be filled at a later point in time while others may remain open. ${ }^{313}$ The fact that the narrator chooses to withhold the most important detail of Samson's marriage plans with the Timnite until verse 4 of Judg 14 is significant because this delay hides the motives of God:

\footnotetext{
${ }^{312}$ Sternberg, The Poetics of Biblical Narrative, 236.

${ }^{313}$ Sternberg, The Poetics of Biblical Narrative, 237.
} 
With the divine architect kept out of view, the order we encounter in the reading greets us with an odd piece of information that at once produces a gap about antecedents. How come that a born deliverer of Israel should want to enter into an exogamous marriage, and with a member of the oppressing nation at that? Samson's parents then voice the incongruity; and his own recalcitrance, closing all interpretation loopholes like youthful thoughtlessness, deepens it further. Only at this late point does the narrator reveal what none of the three human subjects knew and two (Samson and his parents) still do not: 'that it was from the Lord.' Our wonder having been aroused, echoed, and drawn out, it proves in resolution justified if somewhat short-sighted: we should have looked for an explanation not (and certainly not only) in Samson's but in God's mind. $^{314}$

While Sternberg's ideas about arousing the curiosity of the reader seem plausible, he credits the narrator with the use of a sophisticated narrative technique while failing to consider the ramifications of claiming that God ignited Samson's passions.

In spite of Sternberg's insightful discussion of timing, his lack of consideration for the questions that may arise from an exploration of divine motive leads him to an erroneous conclusion about reader response. Sternberg argues that once a gap is closed with an explanation, readers return to the beginning of the text with a better understanding of the situation: "We reread on enlightenment, and with redoubled attention, what we read before in artful darkness. In terms of validation, therefore, the gap's multiple effect from opening to authoritative closure only enhances the sense of relevance given by its temporariness. Its very closure, in perceptibly belated retrospect, establishes that it was there in the first place. ${ }^{\prime 15}$ Sternberg suggests that the narrator satisfactorily answered the reader's questions. Something, however, still seems amiss. While he proposes that the narrator may have enlightened the reader by answering the

\footnotetext{
${ }^{314}$ Sternberg, The Poetics of Biblical Narrative, 238.

${ }^{315}$ Sternberg, The Poetics of Biblical Narrative, 238.
} 
question, I argue that the answer has ignited new questions, demanding answers that may prove difficult to find.

\section{Expectations}

A reader approaching Judg 14 would have expected great things of the hero. Based on his birth in chapter 13 and the concern of his parents, Samson would surely fulfill his destiny. The reader's view of Samson, however, changes as the character leaves his home for Timnat, giving in to his desires while ignoring his parents. ${ }^{316}$ Before his strength has a chance to manifest itself, Samson finds his weakness in the form of the Timnite woman. The consecrated Nazirite with a divine purpose has turned into someone far different. Samson dashes the hopes of his parents and readers when instead of becoming a holy hero, "we get a womanizing adventurer. Samson shows no interest in resisting the Philistines and very little interest in Yahweh. His agenda is set by his passions, which first lead him to seek to live with the Philistines. Later, when his marriage goes awry, his passions lead him to seek revenge. Being God's agent for delivering Israel has no part in Samson's conscious plans." ${ }^{\text {317 }}$ As Samson violates trust and expectations, readers find themselves in a new position.

Klein asserts that Samson's decline affects readers by elevating them from observers to judges:

In prior narratives, the judges were implicitly judged by Yahweh . . . and the reader was put in the position of observer. In this narrative, Samson's behavior - after all the expectations generated by the

\footnotetext{
${ }^{316}$ Klein, The Triumph of Irony, 116.

${ }^{317}$ Pressler, Joshua, Judges, and Ruth, 215.
} 
annunciation, the allusion to Sarah (and Hagar), and the consecration as a nazirite - is so contradictory to expectations that the reader must recognize the irony that Samson is blind to. The reader is drawn into the role of ironist. As Yahweh is knowledgeable and Israel is victim, the reader is knowledgeable about Samson - and Samson is victim. The reader is, in effect, put in the position of Yahweh as Samson betrays the anticipations generated by the annunciation, the birth and the nazirite dedication. Israel is reflected in Samson's foolish ways, and the reader must judge Samson as Yahweh has judged Israel. ${ }^{318}$

Too much power and knowledge, however, may negatively impact the reader. By inserting 14:4 in the text, the narrator creates a host of new problems for the reader. These difficulties lead to a discussion of implications of omitting the verse.

Omitting 14:4

Deleting Judg 14:4 could change the reader's view of Samson. The omission of 14:4 grants agency to Samson, giving him control over his actions rather than attributing his desires to Yahweh. ${ }^{319}$ Therefore readers can base his decision to visit the Timnite woman as doing what is right in his own eyes. The moral and theological implications of whether or not Yahweh is behind this desire no longer matter, meaning that the reader has to wrestle with the text far less. The omission of 14:4 prevents readers from calling Yahweh's actions into question.

The reader is left to assume that Samson's own passions cause him trouble. He ignores his parents' advice, and he fails to live up to reader expectations or his purpose in life. Like the brothers of Joseph, Samson serves as Yahweh's unwitting accomplice.

\footnotetext{
${ }^{318}$ Klein, The Triumph of Irony, 117.

${ }^{319}$ Exum sees Samson a comic hero who "undergoes little or no character development. He does not learn from his mistakes, nor is he explicitly held morally accountable for them" ("Lovis," 413).
} 
Based on this view, Samson's desire for the Timnite arises from his own human desire and not divine incitation. Nevertheless God uses Samson's lust for a greater purpose. The Implications of Judges 14:4

Some reasons, however, support including the troublesome passage. Judg 14:4 places the story of Samson within the Deuteronomistic theme of divine control. The idea that all events — whether good or bad — are "of the Lord" often appears in the Deuteronomistic History. One example is the belief that Doeg the Edomite "was detained by the Lord" (1 Sam 21:7) in order to provide Saul with information. This verse explains how Saul found out about David's visit to Ahimelech and sentenced the priest, his family, and the city of Nob to death. Although this line of thinking makes many modern readers uncomfortable, the Deuteronomist embraced this type of worldview. Keeping the verse also gives credence to the contention that Yahweh had to break the attraction between the Israelites and the Philistines. With the Israelites unwilling to fight for themselves, Yahweh had to act - even if the deity chose to do so from behind the scenes.

Neither omitting nor keeping Judg 14:4 really exonerates Samson. In all of the possible interpretations covered in this chapter, he appears to give in to his lusts-even if Yahweh appears to be the original cause of his desires. While 14:4 may make Yahweh responsible for the attraction to the Timnite woman, the deity hardly seems responsible for Samson's other liaisons. ${ }^{320}$

\footnotetext{
${ }^{320}$ Although the possibility exists that 14:4a could apply to Samson's other dalliances as well, it seems unlikely. Both the story of the Gaza prostitute and Delilah reflect times when the Philistines start conflicts with Samson and are the direct opposite of 14:4. If anything, they reveal Samson's complete abdication of any attempt to deliver Israel.
} 
Several interpretations of Judges 14:4 focus too heavily on removing any culpability from Yahweh. Arguing that Samson himself pursues the Timnite in order to justify his conflicts with the Philistines completely eliminates Yahweh from the equation. Although these proposals prove interesting, such interpretations explain away God's actions instead of actively considering their ramifications.

The narrator may have hoped that the reader would not ask too many questions about this text. While the narrator's explanation may have created additional questions and problems for ancient readers, Greene argues that "the issue of the relationship between divine sovereignty, human responsibility and punishment, was either not a significant issue for the contemporary reader, or one that the narrator chose to let him ponder." ${ }^{321}$ The narrator may have counted on the reader to trust in the sovereignty of God without asking too many questions.

The reader may have had good reason to trust narrator since the narrator has struggled with many perplexing issues. Alter illumines the strivings of the narrators:

The monotheistic revolution of biblical Israel was a continuing and disquieting one. It left little margin for neat and confident views about God, the created world, history, and man as political animal or moral agent, for it repeatedly had to make sense of the intersection of incompatibles - the relative and the absolute, human imperfection, and divine perfection, the brawling chaos of historical experience and God's promise to fulfill a design in history. The biblical outlook is informed, I think by a sense of stubborn contradiction, of a profound and ineradicable untidiness in the nature of things, and it is toward the expression of such a sense of moral and historical reality that the composite artistry of the Bible is directed. ${ }^{322}$

\footnotetext{
${ }^{321}$ Greene, "Enigma Variations," 64. Greene contrasts the story with 2 Samuel 24 where God has David conduct a census and then makes him choose a punishment for following the divine command.

${ }^{322}$ Alter, The Art of Biblical Narrative, 154.
} 
The biblical narrator combated these deconstructive possibilities by attempting to create unity in texts by harmonization, obtrusion, and other literary tools. In particular, the Deuteronomist held to a belief in the one God worshipped at the one temple under the one king in the face of foreign gods, the destruction of the temple, and the shattered promises of the monarchy. By wrestling with Judg 14:4, readers find themselves in the same struggle as these narrators, attempting to create meaning in a world that does not always lend itself to easy solutions.

\section{Conclusions}

This study of Judg 14:4 shows that many readers will find something amiss when confronting the text. At first, something only slightly looks out of place; but the many questions that arise out of the passage make issues in the text seem unsettled. Whether the narrator is responsible for this problem or the reader is to blame for rummaging around and asking difficult questions, Judg 14:4 affects reader response to the account as a whole. And while omitting the verse may be supported, perhaps this choice ignores the difficulty the narrator faced when dealing with Samson. Interpreters should attempt to place themselves in the narrator's situation: explaining Samson's divine power and potential motivation in light of his human foibles and carnal desires. If Yahweh is trying to give the reluctant Samson/Israel a reason to fight the Philistines, interpreters should not be so reluctant and complacent. They must accept the challenge to wrestle with this text.

Judges 14:4, therefore, provides a nice way to engage the methodology introduced in the previous chapter: 
(1) The verse contains both an omniscient remark and an obtrusive comment, allowing for a clearer delineation between the two terms.

(2) The narrator obtrudes by attempting to answer the reader's question concerning why the hero desires an exogamous marriage.

(3) The essentiality of the obtrusive comment remains open to debate. On the one hand, the character of Samson undergoes no real changes from omitting 14:4. Based on his later dalliances with the prostitute in Gaza and Delilah, an explanation about his interest in the Timnite seems unnecessary. On the other hand, the comment removes agency from Samson. He no longer acts according to the desire of his eyes but falls in line with the vision of Yahweh. These factors increase the possibility that the original story lacked the comment, and the Deuteronomist added it in order to insert the theme of divine control into the text.

(4) The obtrusion breaks the frame of the story at a key location because Judges 14:3 attempts to tie Samson's actions to all of Israel since he is doing what is right in his eyes.

(5) The narrator purposefully leaves a gap in the sin-cry-rescue pattern in order to show how Samson restores it. However, the narrator is uncomfortable with leaving a gap in chapter 14 and seeks to define Samson's relationship with the Timnite by adding verse 4 .

(6) The variety of explanations in the history of interpretation reveals the troublesome nature of this verse. If the narrator intended to fill in a gap to prevent readers from asking questions about Samson and the Timnite, exegesis of the passage shows that the narrative interruption may have created additional questions. 


\section{CHAPTER IV}

\section{READER RESPONSE, NARRATOR FORESIGHT AND FORECLOSURE}

Reader response criticism focuses on the conversation between the text and the reader. The voice of the narrator is often overshadowed by this exchange, particularly in the case of the generally quiet, non-intrusive biblical narrator. Even in their discussions of the narrator, scholars do not always consider the fact that the narrator acts as a reader of the text being composed or redacted. As the initial reader of a text, the narrator foresees some of the questions that may arise from textual gaps or inquisitive readers. The narrator employs literary strategies based on the type of reader envisioned. If the narrator anticipates a knowledgeable reader, a gap may be left in the narrative. If the narrator perceives that a creative or theologically presumptuous reader will come to an undesired response, the narrator will obtrude. ${ }^{323}$ The narrator steers readers through both gaps and obtrusions. The strategic narrator relies on the reader's anticipated responses to gaps and ambiguity in order to manipulate the reader into reaching a particular conclusion. The obtrusive narrator overtly enters the text, manipulating the reader into accepting the interpretation spelled out by the narrator. The biblical narrator allows the reader to have some freedom in the interpretation of the text, relying on the reader to create meaning by logically filling in gaps; however, the narrator occasionally exerts greater control over the reader, behaving obtrusively in order to limit the reader's power.

\footnotetext{
${ }^{323}$ Keith Bodner discusses the creative reader in "Is Joab a Reader-Response Critic?" JSOT 27.1 (2002): 19-35. Robert Alter discusses the theologically presumptuous interpreter in The David Story: A Translation with Commentary of 1 and 2 Samuel (New York; London: W. W. Norton \& Company, 1999), 147.
} 
By anticipating reader questions and responses, the narrator blocks undesired interpretations with obtrusions.

This chapter explores the calculating nature of the narrator by examining areas where the narrator relies on the reader's knowledge and desire for coherence as well as areas where the narrator worries about the reader's presumptuousness and subverts the reader's inclinations. This chapter further reveals the shrewdness of the narrator by introducing a new type of obtrusion. A non-break frame obtrusion occurs when the narrator waits for a natural interruption of the plot, such as a cessation of action, and places an obtrusion outside of the frame. Through an examination of selected breakframe and non-break frame obtrusions in the Deuteronomistic History, I contrast the occasions where the narrator depends on the knowledgeable reader to fill in gaps with those instances where the narrator controls the theological presumptuous reader with obtrusions. In the book of Joshua, the narrator relies on the reader's desire for coherence to limit the force of the potential contradictions in the book. In many instances in Joshua, the narrator envisions a knowledgeable reader and obtrudes to provide explanations to this reader's questions. By examining the conversations that occur between the text, the reader, and the narrator, I explore these obtrusions. In the book of Judges, I consider the challenges faced by the narrators as readers of the Israelite entry into the Promised Land. I examine their wrestlings with the situation and the various explanations they offer. Next, I highlight two potential non-break frame obtrusions in Judg 9. Focusing the remainder of my attention on the broader Davidic narratives, I analyze David's dual role as a reader and narrator of his own story. I discuss the way David acquires knowledge as a reader and then acts as a narrator who manipulates it for his own benefit. Other skillful 
readers and narrators such as Abigail and Joab guard themselves against David's interpretations. At the end of this section, I consider the ways in which David attempts to rewrite the narrative of his affair with Bathsheba, only to fall prey to the gap that the prophet Nathan creates in his parable. A brief review of scholarship on the framing of biblical texts creates the necessary foundation for these discussions because narrative structure assists the narrator in controlling the reader.

\section{Building a Framework}

As the governing force of narrative, a framework consists of several essential parts, including action sequences, plot, time, etc. The field of poetics studies these "building blocks of literature and the rules by which they are assembled." 324 An understanding of these rules, and the ways in which a narrator works with them or against them, is foundational for examining narrative obtrusiveness. Break frame obtrusions always defy these literary standards because they interrupt plot and action sequences by disrupting the narrative framework. In contrast, non-break frame obtrusions work within the parameters of literary rules, keeping the frame and plot of a story intact.

An indispensable part of the framing of a story, plot "is the organizing force or principle through which meaning is communicated." 325 The "structure of the plot-i.e.

\footnotetext{
${ }^{324}$ Berlin, Poetics and Interpretation,15. According to Berlin, poetics helps scholars to understand the "basics of biblical narrative - its structure, its conventions, its compositional techniques — in other words, how it represents that which it wishes to represent" (13). For more on poetics and interpreting texts, see Greger Andersson, Untamable Texts: Literary Studies and Narrative Theory in the Books of Samuel (New York; London: T \& T Clark, 2009), 18-22.

${ }^{325}$ David M. Gunn and Danna N. Fewell, Narrative in the Hebrew Bible (Oxford Bible Series; ed. P. R. Ackroyd and G. N. Stanton; Oxford; New York: Oxford University Press, 1993), 101.
} 
what happens and in what order it happens" is the main form of the frame. ${ }^{326}$ Due to the general absence of the narrator's voice in the text, action becomes the driving force in biblical narrative, creating the plot and helping the reader understand the characters and the meaning of the story. ${ }^{327}$ To communicate meaning, biblical narrators generally focus on action sequences which constitute the most essential "building blocks of narrative." Combining similar repeated action sequences gives a kind of inner coherence to biblical books. ${ }^{328}$ The narrators create these structures to house various stories because "repeated action sequences, say of punishment and rescue, produce a redundancy that may help create a sense of coherence in composite material." ${ }^{329}$ Knitting disparate stories together through the framework created by redundancy displays the narrator's editorial skills in unifying stories and appealing to the reader's desire for coherence. ${ }^{330}$

Narrative interruptions may challenge the reader's inclination to look for consistency in a text. Nathan Klaus notes that in these instances the narrator adds explanatory and elucidatory comments of his own, using his own idiom. By utilizing this device, the narrator diverts his readers' attention from the sequence of the plot. The explanatory remarks of the narrator are

\footnotetext{
${ }^{326}$ Berlin, Poetics, 101. Adrian H. Curtis further defines plot: "Plot can be understood on a number of levels: at its most basic it may refer to a story's general framework, but it can also be understood in terms of the arrangement and relationship of incidents one to another, or may even place stress on the mind that does the organizing of incidents rather than on the incidents themselves" (Joshua [Sheffield: Sheffield Academic Press, 1994], 83). In my discussion of Gen 22:1, I showed how adding information at the beginning of a story completely changes the way a story is read. See my discussion of location in my methodology chapter.

${ }^{327}$ Bar-Efrat, Narrative Art, 95.

${ }^{328}$ Robert C. Culley, Themes and Variations: A Study of Action in Biblical Narrative (SBLSS 23; Atlanta: Scholars Press, 1992), 51.

${ }^{329}$ Culley, Themes, 52. For a review of scholars and structural analysis, see Culley, Themes, 55-56. For various views on unity in the biblical text, see Culley, Themes, 25-33.

${ }^{330}$ In my discussion of Joshua in this chapter, I will consider the reader's desire for consonance more fully.
} 
a powerful tool in his hand for transmitting his message to his readers and for conveying his worldview unequivocally and with utmost clarity. ${ }^{331}$

The fact that the narrator's own thoughts rarely appear in the text increases the importance of attending to these additional building blocks that contribute to narrative meaning outside of the plot. These blocks represent the narrator's response to the reader's potential questions or assumptions. Such issues may arise from the conversation between the text and the reader. This conversation is essential because "meaning is found when what is important to the reader and what is important in the text interact." 332 Should the narrator envision an objectionable interpretation arising from this interaction, the narrator may insert an obtrusion in order to foreclose the outcome.

The introduction of obtrusive elements may negatively affect the literary structure. Bar-Efrat writes, "incidents are like building blocks, each one contributing its part to the entire edifice, and hence their importance. In the building which is the plot there are no excess or meaningless blocks." ${ }^{, 333}$ Obtrusions represent the insertion of new and perhaps disruptive chunks of information. They are excess blocks loaded with meaning designed to influence reader response. Rather than simply building upon the meaning of the plot, they also "block" the reader's potential interpretations, redirecting the reader to the narrator's desired view of the text. As excess and anomalous elements, such obtrusions restructure the text in new ways.

\footnotetext{
${ }^{331}$ Nathan Klaus, Pivot Patterns in the Former Prophets (JSOTSup 247; Sheffield: Sheffield Academic Press, 1999), 99. Klaus states that 9:56 "interrupts the sequence of events." However, this non-break frame obtrusion occurs after the events have concluded. See also Shimeon Bar-Efrat, "Some Observations on the Analysis of Structure in Biblical Narrative," VT (1980): 154-73.

${ }^{332}$ Gunn and Fewell, Narrative, 101.

${ }^{333}$ Bar-Efrat, Narrative Art, 93.
} 
The anomalous nature of obtrusions may create problems for readers. Bar-Efrat points out that "there are very few events in biblical narrative which have neither a causal nor sequential role to play in the chain of the narrative."334 Although the narrator interjects an obtrusion as a new link in this chain, these attempts to control the reader could disconnect the reader from the plot or the frame. In such instances, the narrator may prefer a non-break frame obtrusion to one that breaks frame. Non-break frame obtrusions influence the response of the reader, but may be less noticeable to the reader due to the potentially jarring nature of a break frame. In a non-break frame obtrusion, the narrator follows literary rules and refrains from interrupting the flow of action by waiting to comment until the completion of an episode or the entire story. In spite of the narrator's selective placement of these comments, any obtrusion has the potential to make the reader more aware of the narrator's manipulation.

\section{Obtrusiveness in Joshua}

Readers, however, often fail to notice both break frame and non-break frame obtrusions due to what L. Daniel Hawk calls "the reader's desire for consonance.",335 While canonical criticism favors textual unity and deconstruction challenges the harmony of texts, reader response illumines the reader's desire to find a coherent meaning in a

\footnotetext{
${ }^{334}$ Bar-Efrat, Narrative Art, 96.

${ }^{335}$ L. Daniel Hawk, Every Promise Fulfilled: Contesting Plots in Joshua (ed. Danna N. Fewell and David M. Gunn; Literary Currents in Biblical Interpretation; Louisville: Westminster/John Knox, 1991), 31. Hawk points to the desire for consonance when readers connection Michal's barrenness with David's disfavor despite the fact that the narrator never explains this situation (32).
} 
text. ${ }^{336}$ Hawk believes that the human mind inclines toward coherence-even in the face of contradiction:

Our structuring operations are essential. We cannot effectively engage the world without them. Yet experience often seems to exceed our constructs. Reality resists and provokes our concords with dissonances and uncertainties. Israel laid claim to fulfillment, but continued to tell its story under the impulse of a promise yet to be realized. ${ }^{337}$

Since narrative is "a way of making sense of human existence," Israel's struggle manifested itself in a narrative that endeavored to address the uncertainties that plagued its existence. ${ }^{338}$ An examination of the book of Joshua reveals the reader's and narrator's attempts to make sense of the Conquest in spite of potential contradictions in the text. ${ }^{339}$

Hawk examines the construction of meaning in Joshua by exploring the relationship between reader, text, and narrator. In writing about the exchange that occurs between the reader and the text, he states, "The process of interpretation thus leads to the evolution of the story as it is shaped and rewritten by the reader, whose perceptions are likewise shaped and reformed by the text." ${ }^{, 340}$ Anticipating this conversation between the text and the reader, the narrator inserts omniscient comments to guide the reader while occasionally adding obtrusions to influence reader response.

Hawk recognizes the inconsistencies that might have led to such insertions, noting that "the book's tensions and contradictions arise either because contrary events are

\footnotetext{
${ }^{336}$ Hawk, Every Promise, 31. For more on "the configuring process by which human beings construct coherent structures of meaning," see Hawk, Every Promise, 19.

${ }^{337}$ Hawk, Every Promise, 145.

${ }^{338}$ Hawk, Every Promise, 31.

${ }^{339}$ For a brief review of various literary theories on the book of Joshua, see Curtis, Joshua, 82-85.

${ }^{340}$ Hawk, Every Promise, 39.
} 
juxtaposed or because the events narrated and the narrator's evaluation of these events are inconsistent. ${ }^{341}$ Reader recognition of textual discrepancies may harm the narratorreader relationship. Even in instances where the narrator attempts to correct problems in the text, new complications may arise, causing the reader to question the narrator.

Some problems may arise in the narrator reader relationship if the narrator questions the interpretive skills of the reader. Both the reader and the narrator serve as partners in the work of interpretation with the reader logically filling in gaps or the narrator providing helpful asides to aid the reader. On occasion, the narrator may worry about the reader's presumptions or discern that a textual issue may lead to an unacceptable response on the part of the reader. As a countermeasure, the narrator may attempt to preclude these possibilities by inserting obtrusions. These obtrusions reveal the narrator's reservations about communicating the narrator's intended meaning to the reader.

Narrators either leave gaps or add obtrusions, depending on whether they envision a knowledgeable reader or a presumptuous reader. Josh 15:63 creates an opportunity to explore the narrator's response to a knowledgeable reader. Hawk believes that a problematic gap arises in this chapter due to the insertion of the verse: "As for the Jebusites who were living in Jerusalem, the people of Judah were not able to drive them out; and that is why the Jebusites live with the people of Judah in Jerusalem unto this day." ${ }^{342}$ According to Hawk, the placement of this note is problematic geographically

\footnotetext{
${ }^{341}$ Hawk, Every Promise, 16.

${ }^{342}$ Richard D. Nelson argues that "verses 20-21a and 63 frame a town list from the kingdom of Judah. The heading of v. 20 connects Judah to a web of similar formulas for the other tribes: 13:23, 28; 16:8; 18:20, $28 ; 19: 8,16,23,31,39,48$. A similar set of headings and summary encompasses the land division for the
} 
because Jerusalem is not in Judah's territory. As a literary problem, the note is "all the more damaging since it occurs at the end of the account, thereby frustrating the drive for closure and leaving a gap in the otherwise well-defined parameters of the text. ${ }^{, 343}$ The narrator simply tacks on a note at the end of a section. According to Hawk, this addition creates a gap.

But the interpretation of this verse hinges on the type of reader envisioned by the narrator. Perhaps the narrator inserts 15:63 in anticipation of a knowledgeable reader's question. Perceiving that such a reader will notice the absence of Jerusalem in Judah's city list, the narrator obtrudes in the text to fill in this potential gap. ${ }^{344}$ Despite the fact that this non-break frame obtrusion fills in a gap for the knowledgeable reader, it may also lead to the gap that concerns Hawk. If that is the case, then the narrator may rely on the reader's knowledge to connect the Jebusites with David's conquest of Jerusalem (2 Sam 5:6-7). ${ }^{345}$ David will drive most of the Jebusites out of the city and unite the tribes of whole people: 13:32; 14:1; 19:51" (Joshua: A Commentary [ed. James L. Mays, Carol A. Newsom, and David L. Petersen; The Old Testament Library; Louisville: Westminster John Knox, 1997], 189).

\footnotetext{
${ }^{343}$ Hawk, Every Promise, 104-05.
}

${ }^{344}$ As a non-break frame obtrusion, this verse clearly deviates from the format of the chapter. Josh 15:2062 lists the cities and towns allotted to Judah with no additional commentary. For example, the narrator references Philistine cities such as Ashdod and Gaza without connecting them to Israel's enemies. In contrast, 15:63 focuses on Israel's failed attempts to wrest control of Jerusalem from the Jebusites.

\footnotetext{
${ }^{345}$ The main point of 15:63 is to address the issue of Jerusalem since the narrator believes that readers may wonder about it. The narrator also wishes to point to David as the champion who conquered the city. See Carolyn Pressler, Joshua, Judges, and Ruth [ed. P. D. Miller and D. L. Bartlett; Westminster Bible Companion; Louisville, Ky.: Westminster John Knox, 2002], 132). However, a great deal more is going on in the biblical text, particularly since Judg 1:21 lists Jerusalem as part of Benjaminite territory. Nelson argues that "What is seen here as Judah's responsibility is laid upon Benjamin in Judg. 1:21, which contrasts Benjamin's failure with Judah's achievement in Judg. 1:8. The assignment of Jerusalem to Judah here contradicts both the boundary descriptions $(15: 8 ; 18: 16)$ and the Benjaminite town list (18:28)" (Joshua, 189).
} 
Israel at this central location. ${ }^{346}$ This obtrusion answers the potential question of a reader while depending on the reader's knowledge to fill in the new gap that may arise.

By allowing a knowledgeable reader to close a gap, the narrator relinquishes some power to the reader. By closing gaps, the reader shapes the text, creates meaning, and contributes to the development of the plot:

The reader responds to the clues provided by the text to fill in the gaps and constructs hypotheses of understanding. These hypotheses are, in effect, the reader's plots, his or her evaluations of textual events and their connections. Thus an understanding of plot as a dynamic phenomenon goes beyond the formal aspects of the text and addresses the interpretive processes that take place between text and reader. ${ }^{347}$

The reader's desire to fill in gaps may result in the narrator's use of obtrusions. If the "reader's plots" interfere with the narrator's plots, then gaps must be closed. An obtrusion is one way to close a gap.

Gaps in the text, the reader's plots, and the narrator's plots reveal the various conversations that occur between the text, the reader, and the narrator. In the book of Joshua, the traditional material of the text forms problems the narrator must address with the goal of creating coherence and avoiding contradiction. The reader's desire for consonance assists in this process since the narrator may rely on the reader's intuition to fill in some gaps. The bond between the reader and the narrator is further strengthened by

\footnotetext{
${ }^{346} 15: 63 \mathrm{~b}$, which states that the Jebusites dwell with the people of Judah in Jerusalem at the time of this writing, may explain the presence of Jebusites in the city (2 Sam 24:16; $1 \mathrm{Kgs}$ 9:20; 1 Chron 21:15). Just as Joshua did not drive all of the inhabitants out of the Promised Land, David did not drive all of the Jebusites out of Jerusalem.

${ }^{347}$ Hawk, Every Promise, 27.
} 
“preunderstandings" which Hawk defines as "shared conventions and perceptions.",348 The repetitive nature of conventions forms an invisible framework that the reader and narrator readily understand. ${ }^{349}$ Readers and narrators give little thought to conventions because they are useful and thus repeated a lot. They are unquestioned because they are commonplace. Sometimes, however, the narrator acts outside of these frames, utilizing break frame or non-break frame obtrusions.

The narrator may also implement another type of obtrusion. Sometimes the narrator obtrudes by commandeering the voice of a character. This narrative device reveals another way the narrator communicates an agenda to the reader and perhaps explains why the narrator seems terse in telling stories. In the book of Joshua, the narrator often utilizes a character's discourse to interpret a scene. In Joshua 2:9-11, Rahab speaks for the narrator, quoting elements of Exod 15:15b-16a; 23:27 and Deut 4:39. The narrator assumes the voice of the character in order to communicate that even the outsider Rahab understands the power of God. The narrator also appropriates the voice of Joshua for specific purposes. Joshua explicitly connects the crossing of the Jordan with the parting of the Sea of Reeds (4:23-24) because both miracles show the Lord's might to other nations and cultivate the fear of the Lord among the Israelites. ${ }^{350}$ However, the narrator

\footnotetext{
${ }^{348}$ Hawk, Every Promise, 31. John Barton argues that "much of the distinctiveness of the Old Testament may well lie in the way that it exploits conventions" (Reading the Old Testament: Method in Biblical Study [Revised and enlarged; London: Darton Longmann \& Todd, 1996], 7).

${ }^{349}$ See Hugh S. Pyper, David as Reader: 2 Samuel 12:1-15 and the Poetics of Fatherhood (Bib Int 23; Leiden; New York: E. J. Brill, 1996), 39-40.

${ }^{350}$ In their translations and commentary, some scholars attribute these words to Joshua while others think that they are the words of the narrator. For example, Robert G. Boling thinks that 4:23-24 continues Joshua's address to the Israelites (Joshua: A New Translation with Notes and Commentary [ABD Vol. 6, with an introduction by Ernest G. Wright; Garden City, NY: Doubleday, 1982], 182). John Gray argues that the verses come from a "Deuteronomistic redactor" (Joshua, Judges, Ruth [ed. Ronald E. Clements; New 
has an additional purpose for this interpretation. The commentary not only reveals the similarity between the two events, but also characterizes Joshua as the new Moses.

Whenever Joshua cannot speak for himself, the narrator comments on the Israelite general's greatness, opening the door for obtrusions. A significant obtrusion occurs when the Gibeonites call the Israelites for assistance. The treaty between the two groups compels the Israelites to fight for their allies. To achieve victory, Joshua commands the sun and the moon to stand still; and a very unique day enters Israelite memory. ${ }^{351}$ After a cessation of action, the narrator provides an omniscient comment, attributing the event to the book of Jasher. The narrator follows up this reference with the obtrusive commentary, "for the Lord fought for Israel. Neither before nor since has there ever been such a day, when the Lord acted on words spoken by a man" (10:14, TNK). While לשמע can be translated "listened," the narrator's hyperbole begs for the use of the word "obeyed."352

J. Gordon McConville and Stephen N. Williams point out similarities between Joshua's words and "Yahweh's commanding speech," noting that this story "gives Joshua

Century Bible Commentary; Grand Rapids: Wm. B. Eerdmans; Basingstoke: Marshal Morgan \& Scott, 1986], 74). Martin H. Woudstra views the verse as "an additional comment by Joshua in reflecting upon the crossing and its meaning" (The Book of Joshua [NICO; Grand Rapids, Mi.: Eerdmans, 1981], 96). These various explanations reveal the narrator's strategic placement of these words. The narrator assumes the voice of the character, provides commentary, and escapes the notice of most readers.

\footnotetext{
${ }^{351}$ This unique day is different from the ordinary occasions in which the narrator references something as being present "unto this day." However, Joshua is an extraordinary individual, and several special days are associated with him. At the crossing of the Jordan in Joshua 3, the Lord tells Joshua that he will exalt him on "this day." After Joshua circumcises the people, the Lord states that on "this day" he has "rolled away the reproach of Egypt" (5:9). And perhaps most significantly, Joshua speaks of choosing "this day" to serve God (23:14-15). Nevertheless the day of sun and moon standing supersedes these days, strengthening Joshua's reputation as a leader.

${ }^{352}$ KJV uses the word "hearkened" while NRSV uses the word "heeded."
} 
an extraordinary authority." ${ }^{353}$ Although the narrator works to elevate Joshua's status as a leader throughout the book, the narrator has gone far beyond convention in potentially making the Lord "obey" Joshua. ${ }^{354}$ This break with the status quo reveals the unique situation confronting the narrator. Nelson argues that Joshua originally spoke to the sun and moon as though they were "heavenly beings" and thus ran afoul of "deuteronomistic orthodoxy," prompting the narrator to proclaim that Yahweh obeyed Joshua. ${ }^{355}$ Other options at the narrator's disposal reveal the excessive nature of the comment. For example, the narrator could have declared Joshua's prayer answered just as $1 \mathrm{Kgs} 18$ tells of the Lord listening to Elijah's request for rain. In this story, the narrator goes to great lengths to protect God and exalt Joshua. The narrator wishes to prevent other gods from competing with the God of Israel. The narrator also desires to reinforce Joshua's prominence. Joshua succeeded Moses, but perhaps he measures up to the great man and even surpasses him. God listens to Moses' pleading and refrains from destroying the Israelites in Ex 32, and God speaks to Moses face to face in Num 12:8. However, no reader could forget that Yahweh obeys Joshua in 10:14.

The narrator makes Joshua an exceptional leader but in the process renders a book of exceptions. Hawk notes how frequently the reader is "confronted with an assertion immediately undercut by an exception." ${ }^{, 356}$ Readers may find it difficult to ignore all of

\footnotetext{
${ }^{353}$ J. Gordon McConville and Stephen N. Williams, Joshua (ed. J. Gordon McConville and Craig Bartholomew; The Two Horizons Old Testament Commentary; Grand Rapids, Mi.; Cambridge, U.K.: William B. Eerdmans, 2010), 53.

${ }^{354}$ Nelson notes that "this was the incident that most impressed later generations about Joshua (Sir 46:4; Josephus, Ant. 5.1.17)” (Joshua, 141).

${ }^{355}$ Nelson, Joshua, 145.

${ }^{356}$ Hawk, Every Promise, 50.
} 
the exceptions in the book because they raise a number of questions, some of which cannot be completely explained away by obtrusions. For example, 11:19 cites Gibeon as the only city to enter into a treaty with Israel. The next verse obtrusively explains why other cities failed to seek such an alliance: "For it was of the Lord to harden their hearts to engage Israel in battle in order that they might destroy them without showing mercy to them and exterminate them just as the Lord commanded Moses" (11:20). Similar to Judg 14:4, the narrator defines the situation as the Lord's doing. This explanation, however, creates new questions: "If Yahweh has indeed been hardening the hearts of the land's inhabitants, why does Yahweh not harden the hearts of the Gibeonites as well? Why does Yahweh allow them to 'make peace' with the Israelites? $(9: 6,11,15) .{ }^{, 357}$ In the obtrusion, the narrator explains the rule while failing to address the questions raised by the exception. Although the narrator may imply that the Gibeonite treaty fits under the category of the "Lord's doing," readers may remember that Joshua made this accord without consulting the Lord. By choosing not to answer questions about the Gibeonites, the narrator protects Joshua, making it appear that God sanctioned Joshua's agreement with the Gibeonites.

Other exceptions answer reader questions. In 11:22 the narrator writes, "None of the Anakim was left in the land of Israel—only in Gaza, Gath, and Ashdod some remained." The narrator may create this exception in anticipation of knowledgeable readers who will recognize the Anakim as giants. This recognition may lead such a reader

\footnotetext{
${ }^{357}$ Hawk, Every Promise, 50. For potential changes to the story in which the redactor sought to exonerate Joshua, see Nelson, Joshua, 123-29.
} 
to wonder why Goliath and other Philistine giants appear in later stories. ${ }^{358}$ The narrator responds to this question via an obtrusion that excepts the giants of Gaza, Gath, and Ashdod.

The way a narrator envisions a reader greatly changes the shape of a text. For example, Josephus reconstructed the story of Joshua with a Roman audience in mind. As a result, he attempted to correct the contradictions that he saw in Joshua. In reframing the narrative for outsiders, he related the story of Joshua as "harmonious and orderly, with little sense of the confusion, disorder, and theological tensions elicited by the biblical account." ${ }^{359}$ In preparing the text for an audience of insiders, the biblical narrator chose not to delete the contradictions but to work through them. ${ }^{360}$ In the end, perhaps the narrator achieved an artistry that revealed promise and fulfillment in flux. Perhaps the narrator hoped that the target audience would view the book of Joshua as a narrative representation of Israel's precarious position in the land. ${ }^{361}$

A study of obtrusiveness in Joshua reveals that reader knowledge often assists and detracts from the narrator's goals. In some instances, the narrator trusts the reader to fill in gaps as the example of Jerusalem and the Jebusites shows. In other instances, the

\footnotetext{
${ }^{358}$ See McConville and Williams, Joshua, 59.

${ }^{359}$ Hawk, Every Promise, 145.

${ }^{360}$ Hans Jürgen Tertel notes the difficulty of determining the origin of a passage. An original author may have written it, or it may be the product of a redactor. His discussion of redaction criticism, however, does not consider the possibilities of oral redaction. As stories are told and retold, storytellers may anticipate reader questions or alter the story based on the way listeners receive it (Text and Transmission: An Empirical Model for the Literary Development of Old Testament Narratives [BZAW 221; Berlin; New York: Walter de Gruyter, 1994], 2).

${ }^{361}$ Hawk, Every Promise, 120. The Pentateuch provides another answer to the problem "namely that if these non-Israelite nations had been wiped out all at once, the land would have been overrun by wild beasts (see Exod. 23:29 and Deut. 7:22)."
} 
narrator obtrudes in the text because reader knowledge may lead to the type of questions that the narrator does not wish to leave open to interpretation. By anticipating that ancient readers might make connections between giants, the Anakim, Goliath, and Gath, the narrator creates yet another exception in the book of Joshua. In the end, perhaps the narrator hopes that the reader's knowledge and desire for coherence will strengthen the book's framework and weaken the disruptive consequences that any additional questions may force.

\section{Obtrusiveness in Judges}

Such questions, however, continue to present problems in the book of Judges. In particular, the narrator must deal with the reality of other nations living in the Promised Land. The beginning of Judges provides three different explanations for their continued presence. God allowed the other nations to remain (1) to punish Israel for unfaithfulness to God (2:1-4), (2) to test Israel $(2: 21-23,3: 4)$, and/or (3) to teach warfare to a new generation (3:1-2). ${ }^{362}$ The first explanation places the fault squarely on the Israelites. As a result of Israel's disloyalty, God will increase Israel's problems with these other nations and their false gods will entice the Israelites. ${ }^{363}$ The second reason, provided in 2:21-23 (and repeated in 3:4), makes the Promised Land a proving ground, testing the Israelites to see whether or not they will keep the way of the Lord. In verse 23, readers who wonder

\footnotetext{
${ }^{362}$ James D. Martin, The Book of Judges, (ed. P. R. Ackroyd, A. R. C. Leaney, J. W. Packer; CBC; London: Cambridge University Press, 1975), 39.

${ }^{363}$ See Sara J. Milstein Reworking Ancient Texts: Revision through Introduction in Biblical and Mesopotamian Literature (Ph.D. dissertation; New York University; Retrieved July 16, 2011, from Dissertations \& Theses: A\&I; [Publication No. AAT 3428044]. Milstein argues that "this short pericope [2:1-5] works to ease the transition from the string of defeats at the end of Judges 1 to the cycle of divine punishment that marks Judg 2:11-19 and frames the narratives in Judges 3-16" (177).
} 
why Joshua failed to drive out these nations discover that God had not allowed Joshua to achieve a complete conquest of the land. Here, the narrator takes care to protect the character while listing yet another reason for the remaining nations.

The practical reasoning behind this testing is also present in the third exposition which focuses on learning warfare. ${ }^{364}$ Rather than blaming the Israelites for unfaithfulness, the narrator reveals that this new generation of fledgling warriors needs to acquire the fighting skills necessary to maintain their control of the land. NRSV renders $3: 2$, "it was only that successive generations of Israelites might know war, to teach those who had no experience of it before." The narrator's use of the word רק ("only) outclasses the other explanations, making the verse highly obtrusive. ${ }^{365}$ creates an exception to the other reasons, becoming the "only" justification for the nations remaining in the land. Rejecting the classification of this verse as a gloss or parenthetical statement, Brian Tidiman argues that the particle should be translated "above all."366 Trent C. Butler goes one step further. He displays the emphatic character of this particle by rendering the beginning of the verse, “The only reason he did this. . "367 While Tidiman's translation

\footnotetext{
${ }^{364}$ Trent C. Butler, Judges (World Biblical Commentary; vol. 8; Nashville: Thomas Nelson, 2009), 60. Butler unites these two utilitarian answers to the problem. He sees "two prongs" in this testing: "One seeks to see if Israel will obey Yahweh $(2: 22,3: 4)$. The other tests them in warfare so that they will know how to conduct holy war (3:1-2).”

${ }^{365}$ In Joshua ר is used to make note of several exceptions: (1) marching around Jericho seven times only on the seventh day (6:15), (2) only Rahab being saved (6:17), (3) keeping only metallic objects for the house of the Lord (6:24), (4) treating Ai as Jericho except for the spoil and cattle (8:2, 27), (5) Hazor alone being burned (11:13), (6) only Anakim remaining in Gaza, Gath, and Ashdod (11:22) (7) only Levi omitted from the inheritance (13:14).

${ }^{366}$ Brian Tidiman, Le Livre des juges (Vaux-sur-Seine: Edifac, 2004), 91.

${ }^{367}$ Butler, Judges, 52.
} 
lessens the value of other explanations and Butler's rejects them, both renderings of 3:2 expose an obtrusive narrator.

Although the text identifies this explanation as the chief or only reason for the remaining nations, all three possibilities reveal the narrators' difficulty in interpreting this crisis. This dilemma draws the reader into the thought world of the narrators: "Such differing explanations for God's failure to rid the land of non-Israelites indicates how worrying the issue was for the ancient authors and their inability to come to any final resolution., ${ }^{368}$ Although reader confusion may arise from these narrative comments, they force the reader to wrestle with the text, giving the reader a taste of the perplexity facing the narrators. The narrators faced a challenging question with no sufficient answer readily available.

This obtrusion and the other explanations for the remaining nations may lessen the narrators' power over the reader. Rather than empathizing with the struggle of the narrators, the reader may find consonance difficult to achieve. Deleting the other explanations could have alleviated this problem. However, the fact the narrators chose against this option reveals the limits of obtrusions. Obtrusions are less drastic solutions than are revisions. By allowing the other reasons to remain, the narrators may show how the most convincing reason surpassed the others. Nevertheless, the narrators may weaken their powers of persuasion, making it difficult for the reader to find coherence in the midst of multiple interpretations.

${ }^{368}$ Pressler, Joshua, Judges, and Ruth, 139. 
Judges 9

In Judges 9, the narrator more skillfully offers explanations for the events surrounding the rise and fall of Abimelech by utilizing an omniscient comment, co-opting the voice of Jotham, and ultimately by creating potential obtrusions. ${ }^{369}$ At the beginning of the chapter, the narrator explains the inner thoughts of the Shechemites by noting their proclivity to follow Abimelech as they push him to accept their offer to rule over them (v 3). ${ }^{370}$ Their alliance leads to the slaughter of the sons of Gideon with only Abimelech's younger brother Jotham surviving the onslaught. The narrator commandeers the voice of Jotham in order to speak against Abimelech. Webb notes, "Whatever Jotham's personal motives may have been, it is clear that he has been adopted by the narrator as his own alter ego, the character in the story who gives voice to the narrator's own interpretation of the situation. ${ }^{371}$ Speaking for the narrator, Jotham pronounces his fable. In the fable, the narrator negatively portrays Abimelech, comparing him to the bramble whose poor leadership led to destruction. The fable warns the Shechemites of the conflagration that will arise from Abimelech's leadership. After Jotham pronounces judgment, he disappears from the narrative.

Without this character as a medium, the narrator more forcefully enters the story through potential obtrusions in 9:23-24 and 56-57:

\footnotetext{
${ }^{369}$ For a discussion of parallels between Gaal's relationship with Shechem and Abimelech's alliance with Shechem, see T. A. Boogart, "Stone for Stone: Retribution in the Story of Abimelech and Shechem," JSOT 32 (1985): 45-56, esp. 50-51.

${ }^{370}$ For a discussion of redaction criticism and Literkritik in Judges 9, see Edgar Jans, Abimelech und sein Königtum: diachrone und synchrone Untersuchungen zu Ri 9 (ATAT 66; St. Ottilien : EOS-Verlag, 2001), 62-83. For more on Judges 9, see Volkmar Fritz, “Abimelech und Shechem in Jdc. IX," VT 32 (1982): 12944.

${ }^{371}$ Webb, The Book of Judges, 156.
} 


\begin{tabular}{|l|l|}
\hline \multicolumn{1}{|c|}{ Judg 9:23-24 } & \multicolumn{1}{c|}{ Judg 9:56-57 } \\
\hline $\begin{array}{l}{ }^{23} \text { Then God sent an evil spirit between Abimelech } \\
\text { and the Shechemites, and the Shechemites dealt } \\
\text { treacherously with Abimelech. }\end{array}$ & $\begin{array}{l}{ }^{56} \text { Thus God repaid the evil of Abimelech which he } \\
\text { had done to his father by killing seventy of his } \\
\text { brothers. }\end{array}$ \\
${ }^{24}$ That the violence to the seventy sons of Jerubbaal \\
$\begin{array}{l}{ }^{57} \text { And all the evil of the men of Shechem God } \\
\text { their brother who killed them and upon the } \\
\begin{array}{l}\text { Shechemites who acted as accomplices in } \\
\text { murdering his brothers. }\end{array}\end{array}$ & $\begin{array}{l}\text { repaid upon their heads. Upon them came the curse } \\
\text { of Jotham, the son of Jerubbaal. }\end{array}$ \\
\end{tabular}

Figure 5. Potential Obtrusions in Judg 9:23-24, 56-57

Webb believes that vv 23-24 and vv 56-57 "complement one another and point to retribution as the thematic key to the story." "372 The first statement in vv 23-24 occurs "at a crucial point in the development of the plot" between the end of Jotham's allegory and the beginning of its fulfillment. ${ }^{373}$ In this verse, God sends an evil spirit between Abimelech and the men of Shechem, causing the ruler's subjects to deal treacherously with him. ${ }^{374}$ While some have argued that the evil spirit plaguing Abimelech contrasts with the Spirit of the Lord empowering other judges, a significant difference between the two is discerned in the narrator's choice of preposition. ${ }^{375}$ The spirit of the Lord comes upon (על) favored judges, whereas the evil spirit comes between (בין) Abimelech and the Shechemites. ${ }^{376}$ The evil spirit creates a rift between the two parties. The narrator's use of the evil spirit precludes the need for a specific explanation about the division between the groups. In discussing evil spirits and this verse, Sasson notes that "as narrative

\footnotetext{
${ }^{372}$ Webb, The Book of Judges, 154. Webb argues that the theme of retribution thematically connects the story to the Gideon narrative (156).

${ }^{373}$ Webb, The Book of Judges, 154. Boogart refers to vv 23-24 as a transition, ("Stone for Stone," 52).

${ }^{374}$ E. John Hamlin, At Risk in the Promised Land: A Commentary on the Book of Judges (ed. F. C. Holmgren and G. A. F. Knight; ITC; Grand Rapids, Mi.: Wm B. Eerdmans, 1990), 103.

${ }^{375}$ For example, Webb argues that "the 'evil spirit from Elohim' (9.23), agent of retribution, is the dark counterpart of 'the spirit of Yahweh' (6.34), agent of deliverance” (The Book of Judges, 158-59).

${ }^{376}$ Other prepositions are also associated with the spirit of the Lord, such אל 1 1 Sam 16:13.
} 
components, they act as dei ex machina, in our case short-circuiting events to get to the meaty part of the story." ${ }^{377}$ By tactfully placing the evil spirit between frames, the narrator eliminates the need for another plot sequence and quells potential reader questions about the conflict.

For Abimelech and the Shechemites, retribution occurs neither as a matter of chance nor as the inevitable consequence of their villainy. Fully aware of their treachery, God intervenes to dole out their punishment. In verse 24, the narrator explains that Abimelech and the Shechemites must face retribution for killing the sons of Jerubbaal. The evil spirit serves as the catalyst for the fulfillment of Jotham's words. With Jotham no longer available to serve the narrator's interests, the narrator invokes the evil spirit, identifying God as the author of the discord between Abimelech and the Shechemites. ${ }^{378}$ Verse 24 explains God's reason for sending the evil spirit: God is avenging the death of Abimelech's brothers. Sasson characterizes this verse as an obtrusion because it affects the reader's response to the figures and events in the story. In his discussion, he points to the infrequent use of obtrusions, suggesting that verse 24 expresses "a strong antipathy on the narrators' part to what Abimelech represented." 379 While other obtrusions have

\footnotetext{
377 Jack M. Sasson, Judges (The Anchor Yale Bible Commentary, forthcoming). See also Victor H. Matthews, Judges \& Ruth (ed. Ben Witherington III and Bill T. Arnold; NCBC; Cambridge: Cambridge University Press, 2004), 109. Matthews points out that the evil spirit "may be a literary vehicle that allows the editor to make clear that there is a divine touch involved in these events" (109).

${ }^{378}$ Wolfang Bluedorn contends that the narrator wants to assure readers that God "is in control even in an environment dominated by Baalism" (Yahweh Versus Baalism: A Theological Reading of the GideonAbimelech Narrative [ed. David J. A. Clines and Philip R. Davies; JSOTSup 329; Sheffield: Sheffield Academic Press, 2001], 187).

${ }^{379}$ Sasson, Judges.
} 
revealed the narrator's desire to protect a favored character, this obtrusion shows the narrator speaking out against a despised figure.

The evil spirit is an intrusive element because it could be omitted from the story based on the characterization of Abimelech and the Shechemites. After seeing the ruthless acts of Abimelech and the Shechemites, the reader hardly finds the rift between them surprising and could easily fill in the gap that would result from removing the evil spirit from the story. ${ }^{380}$ Although the story could function without the evil spirit, the presence of this otherworldly figure adds a new interpretive scheme to the narrative. The Abimelech/Shechemite alliance unravels, not only because they themselves are evil but also because God desires to repay them for their evil deeds.

An evil spirit is similarly utilized in the story of Saul because its presence changes the way readers view the king. The arrival of the evil spirit is simultaneous with God's departure from Saul in 1 Sam 16:14. God exacerbates his abandonment of the king by agitating him with this spirit. Even without the evil spirit, Saul would probably have been jealous of David. The evil spirit, however, pushes Saul to behave badly toward David. The inclusion of this figure counteracts the anointing that the Lord had placed on Saul and reveals yet another reason why Saul deserves his fate. Saul must appear worthy of death because of his deeds, the evil spirit that torments him, and the witch he consults. In the Abimelech account, God condemns both factions and sends the evil spirit between them. The conflict ultimately ends in Abimelech's death. The story appears to

\footnotetext{
${ }^{380}$ Matthews points out that greed and mistrust may abound between the two parties with or without the presence of the evil spirit (Judges \& Ruth 109). Bluedorn argues that "the Shechemites' behavior is thus depicted as unjustified, and the narrator invites the audience to condemn their behavior" (Yahweh Versus, 234). He ignores the characterization of both parties because he believes that the Shechemites should be condemned because they are Baal worshippers.
} 
conclude in verse 55 when the narrator offers up the common ending, "every man went to his home" (cf. Judg 7:7; 1 Sam 26:25). Yet the narrator makes certain that the reader comes to the desired conclusion by adding verses $56-57$. These comments occur outside of the framework of the narrative, and the narrator designed them to guide readers to a response in which readers give God full credit for the retribution. Sasson notes the location of these verses outside of the narrative framework, but he does not define them as obtrusive: "The coda stands out from the narrative and might, frankly, be obtrusive were it not that it provides the necessary moral to Jotham's fable."381 On the level of genre, the verses are essential because a fable must have a moral. However, they also reveal the narrator's doubts about the reader's interpretive ability, and so, with these lines makes certain that the reader recognizes the necessity to fulfill Jotham's prophecy. ${ }^{382}$

In Judg 9, the narrator makes good use of a variety of literary devices by making omniscient comments, co-opting the voice of a character, and utilizing a non-break frame obtrusion and a moral. The artful narrator chooses the best tool for each circumstance. The omniscient comment aids reader understanding. The narrator drives the action and interpretation of the story while hiding behind Jotham. The skillful placement of commentary in the non-break frame obtrusion allows the narrator to fill in a gap and move the plot forward without beginning a new action sequence. The moral interprets the

\footnotetext{
${ }^{381}$ Sasson, Judges.

${ }^{382}$ Klaus argues that verses 56-57 explain this fulfillment, and "they reintroduce to the story (see vv. 23-24) the dimension of divine protection, that is to say, dual causality. In these stories we encounter the dimension of the co-incidental, natural development of events, or, in other words, concealed divine protection in revealed history" (Pivot Patterns, 99). While dual causality can explain the events in this and other narratives, the biblical narrator most likely viewed situations from the perspective that God was always in charge. This way of reading events raises the questions of whether the narrators believed in dual causality or saw God as the cause of everything. For more on the dual causality principle, see Yairah Amit, “The Dual Causality Principle and Its Effects on Biblical Literature," VT 37 (1987): 385-400.
} 
situation for the reader and reinforces the comments in the non-break frame obtrusion.

These devices reveal the various ways the narrator attempts to control reader response by introducing certain interpretations and blocking off others.

\section{David and Obtrusiveness in $1 \& 2$ Samuel}

In 1 and 2 Samuel, David also exercises great control over narratives. He often interprets the events surrounding him in a manipulative manner, attempting to rewrite them for his benefit. David serves as an example of both narrator and reader. As a narrator, David often takes control of another individual's story, reshapes it, and reinterprets it for his own purposes. Hugh S. Pyper focuses on David's interpretative abilities as a reader, calling David "an exemplar of the serious reader of the Old Testament." ${ }^{383}$ He bases his work on a quote from Louis Alonso Schökel, "What we must seek, what the bible requires of us, is readers like David; willing to enter into dialogue with the text, participants in the drama of human existence, willing to take decisions in order to accept their consequences properly." ${ }^{384}$ David's dialogues with the text reveal both the creativity of the reader as well as the obtrusiveness of the narrator.

Much of David's story revolves around his clashes with Saul, and his ability to acquire and control information proves highly important in the unfolding narrative. ${ }^{385}$

\footnotetext{
${ }^{383}$ Pyper, David as Reader, 5.

${ }^{384}$ Pyper, David as Reader, 3. The quotation from Luis Alonso Schökel originally appears in "David y la mujer de Tecua: 2 Sm 14 como modelo hermenéutico" in Hermenéutica Biblica de la Palabra (Madrid : Ed. Cristiandad, 1987), 217-30.

${ }^{385}$ As Saul and David vie with each other, the narrator often provides omniscient information about Saul's innermost thoughts but remains laconic when discussing David. See Polzin, Samuel and the Deuteronomist, 190-193. See also K. L. Noll, The Faces of David, (JSOTSup 242; Sheffield: Sheffield Academic Press, 1997), 60. See J. P. Fokkelman, Narrative Art and Poetry in the Books of Samuel: A Full Interpretation
} 
Saul scrambles to find David, and David strives to anticipate and counter Saul's moves. While David's shrewdness in military maneuvers often garners a great deal of attention, his skillful manipulation of stories as a reader and narrator deserves more attention. ${ }^{386}$

As a reader, David often rejects the interpretations of others. In 1 Sam 24, when David has the chance to murder Saul in a cave, David's men attempt to drive the action by becoming narrators of the story. They suggest a potential reading for David. They interpret the incident as the fulfillment of God's promise to their leader. To David's men, the situation represents more than an opportunity to dispose of a foe. God has given David a divine mandate to do with Saul as he pleases. They support their argument by quoting the words of the Lord, "This is the day of which the Lord spoke to you, 'I will give your enemy into your hand, and you will do to him whatever is right in your eyes"” (1 Sam 24:5). Although no scripture contains these specific words of the Lord, the conclusion reached by David's men seems logical. ${ }^{387}$ In spite of their prodding, David rejects this reading of the story. Even though God has promised David the kingship, he refuses to do what pleases him. He refrains from killing the Lord's anointed and merely cuts off the corner of Saul's cloak.

Based on Stylistics and Structural Analysis (vol. 2, The Crossing Fates [I Sam. 13-31 and II Sam. 1]); Assen: Van Gorcum, 1986), 430.

${ }^{386}$ For a discussion of David and the DSS, see Claude Coulot, "David à Qumrân" in Figures de David à travers la Bible: XVIIe congrès de l'ACFEB, Lille, ler-5 septembre 1987 (ed. Louis Desrousseaux and Jacques Vermeylen; LD 177; Paris: Cerf 1999), 315-43. Coulot argues that David was often mentioned to point readers to positive characteristics of the king (331).

${ }^{387}$ We cannot be sure whether David did not utter this quote since quotations from the ancient world are hardly precise and are not always available in scripture. David's men may have come to a creative assumption about what David told them. It is also possible that David manipulated his men with stories about taking the kingdom from Saul - an idea that does not make it into the text. A. Graeme Auld believes that David's men have made up this quotation because the reader has no knowledge of it, and David never describes Saul as an enemy ("1 and 2 Samuel" in Eerdmans Commentary on the Bible [ed. J. D. G. Dunn and J. W. Rogerson; Grand Rapids: Eerdmans, 2003], 213-45, esp. 226). 
As the story moves forward, David wrestles with two different interpretations of the episode, ultimately manipulating both of them to benefit his cause. In the first version, David completely rejects the narrative presented by his men. The narrator comments on David's state of mind, disclosing the grief that David felt for even going so far as to cut off a piece of Saul's garment. And, yet, when he speaks to Saul, he narrates a different story. In verse 10, he tells Saul to recognize the overt action of God in the unfolding of events, "You can see for yourself now that the Lord delivered you into my hands in the cave" (TNK). He recounts the pressing words of his men to Saul, letting the king know that only his anointing saved his life.

This story reveals that David prefers the role of narrator to the role of reader. David refuses to be the reader when he rejects the explication provided by his men. Alter argues that the future king's men "exhibit a certain theological presumptuousness." 388 Readers of the biblical text may have similar tendencies. Like David's men, these readers may insert inadmissible interpretations into the narrative and exert too much control over texts. The biblical narrator refuses to relinquish this amount of power to these overly ambitious readers and secures the text against theological presumptuousness by creating obtrusions.

In 1 Sam 26, David again rejects the reading of one of his men as he and Abishai sneak into Saul's camp and have the chance to eliminate the king. Walter Brueggemann calls this story "more complex in its telling" than its equivalent in 1 Sam 24, noting that

${ }^{388}$ Alter, The David Story, 147. 
“this narrative is freighted with divine providence." ${ }^{389}$ Both Abishai and David cite divine intervention as they voice their readings of the matter. When David and Abishai enter the camp, David refuses to kill his nemesis in spite of Abishai's reasoning that the Lord has presented David with an undeniable opportunity to execute Saul. Abishai even offers to kill the king, but David rejects this reading and spares his adversary.

Again, David assumes the role of narrator by presenting two different readings of the situation. David both claims and denies divine intervention as he reviews the events with Saul and Abner. When speaking to Abner, David acts as though God had no hand in shaping the events. This denial contradicts the biblical narrator's obtrusive explanation that a deep sleep from the Lord overcame Saul and his men and presented an easy opportunity for David to kill Saul (1 Sam 26:12). ${ }^{390}$ This obtrusion blocks readers from alternate explanations. Some readers might think that David and Abishai's stealth allowed them to gain access to Saul. Others might presume incompetence on the part of Saul's army. The narrator intervenes to explain that God is at work in these events. In his taunt to Abner, David rejects this reading by blaming Saul's general for his negligence. Carefully omitting God in his speech to Abner, David seizes the opportunity to condemn Saul's general, perhaps signaling his death in 1 Sam 31. Indeed one of the main goals of the chapter appears to be the foreshadowing of the deaths of Abner, Saul, and Saul's army. David tells Abner and Saul's men that they are worthy of death for failing to

\footnotetext{
${ }^{389}$ Walter Brueggemann, Power, Providence, and Personality: Biblical Insight Into Life and Ministry (Louisville: Westminster/John Knox, 1990), 57-58.

${ }^{390}$ For a good discussion of sleep with references to ANE literature, see Thomas H. McAlpine, Sleep, Divine, and Human in the Old Testament (ed. David J. A. Clines and Philip R. Davies; JSOTSup 38; Sheffield: Sheffield Academic Press, 1987).
} 
protect the king. ${ }^{391}$ In his conversation with Abishai in 1 Sam 26:10, David hypothesizes the various ways Saul may meet his end. ${ }^{392}$

But Saul will not die on this day. Before David can offer another read on the episode, Saul speaks with him. In a speech perhaps co-opted by the narrator, Saul offers a pro-David reading of the events, ultimately admitting his "great mistake" in pursuing David (1 Sam 26:12). In response, David invokes the Lord, letting Saul know that although God had given him an occasion to do so he chose not to kill him. David's conversation with Saul differs greatly from his taunt to Abner. When speaking to Abner, David never associates the lax security around Saul with divine intervention. However, in addressing Saul, David claims the favor of God, agreeing with the biblical narrator's assessment of God's involvement. While historical criticism might explain this difference by pointing to disparate sources, narrative criticism and reader response open up the possibility that David interprets the matter in the ways most advantageous to him.

By refusing the role of reader and assuming the mantle of narrator, David manipulates the event, condemning Abner to death while claiming credit for sparing Saul's life. David also has a greater purpose for acting as a narrator in these stories. By sparing Saul, he builds a case against regicide. This point is made sharper in David's punishment of the Amalekite who brought Saul to his death.

As a man skilled in manipulating stories, David appropriates the narratives of others — often to their detriment. Less beguiling narrators fall prey to David's interpretation of events. Such is the case when an Amalekite appears on the scene,

\footnotetext{
${ }^{391}$ In 1 Samuel 26:16, David speaks to all of Saul's men by using the plural: "All of you deserve to die" (TNK).

${ }^{392}$ Note the similarities between these possibilities and the choices God gives David in 2 Sam 24:12-13.
} 
identifies himself as Saul's executioner, and poorly narrates the king's demise. David proves himself a skillful interpreter as he "reads the evidence" in the Amalekite's account. ${ }^{393}$ The Amalekite begins his story, stating that "by chance" he happened to be on Mt. Gilboa. Pyper asks, "Who happens on a major battlefield 'by chance'?",394 Indeed the story arouses suspicion from the beginning. Another potential translation of the Amalekite's words renders the opening as "Would you believe ..."395 The Amalekite speaks as though relating a dream. ${ }^{396}$ This wordy storyteller could learn a great deal from a skillful narrator like David as well as the laconic biblical narrator who carefully and economically chose words.

By questioning the Amalekite, David creates an opportunity for the alleged murderer of Saul to condemn himself. Pyper illumines David's adroitness in speaking with the Amalekite: "David is revealed as a skilled practitioner of the art of anacrisis, of the eliciting of a response which can be turned against the speaker." ${ }^{397}$ At first, David merely appears to desire news of the battle. However, he may notice that the Amalekite possesses Saul's crown and armlet, leading him to wonder about the circumstances surrounding Saul's death.

The Amalekite not only takes possession of items that belong to Saul, but he also takes possession of the narrative of Saul's death. In providing David with information

\footnotetext{
${ }^{393}$ Pyper, David as Reader, 21.

${ }^{394}$ Pyper, David as Reader, 22.

${ }^{395}$ Pyper, David as Reader, 22.

${ }^{396}$ See Berlin, Poetics, 91-93.

${ }^{397}$ Pyper, David as Reader, 27.
} 
about the demise of Saul, the Amalekite misreads the situation. Although Israelite hatred of the Amalekites is well known (Ex 17), this Amalekite may have assumed that his position as an outsider granted him license to kill Saul. Fokkelman offers a nice discussion of the way the Amalekite created a new narrative by replacing Saul's armorbearer in the story. For Fokkelman, the narrative with the armorbearer and the Amalekite's story pivot on the word "fear." In 1 Sam 31:4, the armor bearer refused to kill Saul because of intense fear. In passing a death sentence on the Amalekite, David speaks of the mercenary acting without fear. ${ }^{398}$ David assumes control of the story that the Amalekite had stolen from the armorbearer. David turns the Amalekite's own words against him, proving himself the superior narrator. By doing so, David further reinforces the idea that no one — not even a foreign mercenary — has the right to commit regicide against the Lord's anointed.

Perhaps the biblical narrators worried that the text might generate reader responses in which the reader turned the words of the narrator against God or a favored character. The narrators may also have envisioned some readers who aspired to gain too much control over the narrative. As a result, the narrators obtruded in texts in order to prevent readers from claiming too much power. David's interactions with the Amalekite reveal the dangers of a narrator allowing someone else to manipulate a narrative. Upon hearing the Amalekite's story, David's role quickly changes: “'David as reader' is 'David as writer' . . . the one who writes the Amalekite's own speech of self-condemnation and

\footnotetext{
${ }^{398}$ J. P. Fokkelman, Reading Biblical Narrative: An Introductory Guide (trans. Ineke Smit; Louisville, Ky.: Westminster John Knox Press, 1999; trans. of Vertelkunst in de bijbel: een handleiding bij literair lezen (Zoetermeer, The Netherlands: Boekencentrum, 1995), 63-65.
} 
puts it in the mouth of a dead 'author'."399 David's rewriting of the Amalekite's version of events proves that wordy and unpolished speech may prove detrimental to a character. A skillful speaker, however, may avert disaster. In 1 Sam 25, Abigail prevents David from attacking her household by bringing gifts of food; but perhaps her real power lies in her ability to persuade her future husband to quell his anger. Appealing to David's ego as well as his God, Abigail proclaims that the Lord favors David. Cleverly, she references a stone and sling, pointing to David's victory over Goliath and speaking of his future triumphs (1 Sam 25:29). Abigail's knowledge of David's story enables her to change the course of events and write a new outcome. Perhaps David saw in Abigail another adept persuader skilled in controlling narratives.

David's powers of narration, however, wane as he attempts to cover up his affair with Bathsheba. ${ }^{400}$ The story begins with the biblical narrator carefully choosing words to explain the situation. The narrator informs the reader of Bathsheba's purification after menstruation (2 Sam 11:4). The skillful narrator wishes the reader to know that Bathsheba is likely extremely fertile at this moment. ${ }^{401}$ When she sends word to David,

\footnotetext{
${ }^{399}$ Pyper, David as Reader, 27. Pyper even surmises a plausible conspiracy theory: "Indeed the swift execution of the messenger could lead a suspicious reader to see the whole transaction as David's shrewd dispatch of his own hired assassin who has carried out the necessary murder of Saul. Whatever the truth of the matter, David makes sure that his own interpretation of these words sticks in the most direct way" (26).

${ }^{400}$ For more on the women in David's life and the problems that the rabbis attempted to correct in the text, see Shulamit Valler, "King David and 'His' Women: Biblical Stories and Talmudic Discussions," in The Feminist Companion to the Bible (ed. Athalya Brenner; Sheffield: Sheffield Academic Press, 1994), 12941.

${ }^{401}$ Scholarship has not provided information about the frequency of bathing in ancient of Israel. Therefore it cannot be known whether David may have thought that Bathsheba was bathing for some other reason than purifying herself after menstruation. Archaeology provides very little information about bathing. Philip J. King and Lawrence E. Stager mistakenly reference Bathsheba's bath as "unrelated to ritual purity" in Life in Biblical Israel ( $1^{\text {st }}$ ed.; Library of Ancient Israel; Louisville: Westminster John Knox Press, 2001), 70.
} 
the reader is unsurprised to learn of her pregnancy and David's undoubted identity as the father. ${ }^{402}$ Upon hearing the news, David attempts to manipulate the story for his own ends. He can create a different reading of the events by convincing Uriah to sleep with Bathsheba. When this option fails, David writes a letter to Joab that serves as Uriah's death sentence.

Fortunately for David, Joab proves himself a shrewd reader and narrator of the circumstances. As a "creative reader" of the predicament, Joab's rejects David's plan to have Uriah's fellow soldiers abandon their comrade on the battlefield. ${ }^{403}$ Since David's ill advised strategy would require conspirators, Joab employs a different strategy. As a narrator, Joab rewrites David's battle plan and has his soldiers go too close to the wall in order to ensure Uriah's death. Joab chose to let the wall-and not his men-assist in the assassination. ${ }^{404}$ In spite of the imprudence of Joab's tactic, the soldiers will be less likely to suspect David's involvement.

Joab, however, anticipates that David may disapprove of his plan. He foresees that David will bring up the story of Abimelech's death. Ingrained in the hearts of generations of soldiers, this story had become a convention that warned against closely approaching a wall. By anticipating David's response to the battle report, Joab tells the

\footnotetext{
${ }^{402}$ Anthony F. Campbell, 2 Samuel (FOTL 8; Grand Rapids, Mi.; Cambridge, U.K.: William B. Eerdmans Publishing Company, 2005), 115. See also Bill T. Arnold, $1 \& 2$ Samuel (ed. Terry Muck, et. al; The NIV Application Commentary; Grand Rapids, Mi.: Zondervan, 2003), 528.

${ }^{403}$ Bodner, "Is Joab," 20.

${ }^{404}$ In reading the situation, David may have assumed that Uriah's loyalty would prevent him from retreating. John I. Lawlor notes that "perhaps a touch of irony is evident here in that the very loyalty which first frustrates the king's purpose becomes the tool that is used to bring about the loyal soldier's death" ("Theology and Art in the Narrative of the Ammonite War (2 Samuel 10-12)," Grace Theological Journal 3.2 [1982]:193-205, esp. 199).
} 
messenger not to answer the question. Instead the messenger is to announce Uriah's death. ${ }^{405}$ This redirection blocks David from accusing Joab of failing to follow orders.

Although perhaps better known for their military strategies, David and Joab adeptly and strategically control narratives. In many cases, David benefits from the way Joab manipulates events. Even though David greatly distances himself from Abner's murder, the elimination of Abner is the elimination of a rival. David vehemently denies any collusion with Joab as he laments Abner's death. But perhaps the narrator worries that the character has not totally convinced everyone. The narrator obtrudes in 2 Sam 3:37 by stating that all of David's troops as well as all of the people of Israel knew that the king had nothing to do with Abner's death. The reader may have not have associated David with Abner's death because of the words of the king; however, this obtrusion may raises suspicions about David.

David also has good reason to be suspicious of Joab because of the general's strategic nature. In writing about Joab's re-interpretation of David's letter, Keith Bodner states, "Even though David benefits from this exegetical maneuver, ironically, it is this recurring pattern of interpretive creativity that ultimately leads to Joab's demise.”406 Solomon does not simply kill Joab because he supported Adonijah. He has him killed because David has already warned him about Joab and pronounced a death sentence on him (1 Kgs 2:5-6). Although David cites the murders of Abner and Amasa as actions that make Joab worthy of death, David was probably more concerned about Joab's strategic

\footnotetext{
${ }^{405}$ Perhaps to protect himself, the messenger changes Joab's orders, showing that he acts as a reader and narrator. See Bodner, "Is Joab," 31-33. See also Gale A. Yee, “"Fraught with Background' Literary Ambiguity in II Samuel 11," Int 42 (1988): 240-58.

${ }^{406}$ Bodner, "Is Joab," 35.
} 
way of manipulating narratives and events more than he was concerned about Joab's past transgressions. Similarly, the biblical narrator recognized the potential harm of interpretive creativity and took measures to defend the text from readers like Joab who might take on the role of narrator.

Perhaps the biblical narrators write laconically and sometimes obtrusively because they recognize the possibility that readers will creatively interpret texts. Although the narrators could not have anticipated the modern reader's hermeneutic of suspicion, they recognized the potential questions and theological presumptuousness of ancient readers that could prove damaging to the meaning they wished to convey. ${ }^{407}$ As elites, these narrators would have understood the importance of carefully weighing words and responses. To prevent the reader from gaining too much interpretive power, they sometimes behaved obtrusively, filling in gaps when they feared the reader's interpretation of an event. If a reader jumped to a particular conclusion when closing a gap, the story might change drastically. Indeed the story of David proves that leaping into a gap can create major problems. When David misreads a situation and attempts to narrate its ending, he faces severe judgment.

Because David's actions with Bathsheba and Uriah displeased the Lord, the prophet Nathan draws the king into a new story. In Nathan's tale of the rich man and the poor man, David represents "a model of the reader in the interpretation of allegory, and

${ }^{407}$ Some modern readers of the Bible may actually be at a disadvantage when reading biblical stories. For example, Marc Brettler argues that the ancient narrator would have trusted the ancient reader to understand that Judges' story of Othniel should not be read as history based on the following clues: the enemy king is named symbolically 'the dark double-wicked one'; the king's name and country of origin rhyme; the Israelite hero is 'borrowed' from a previous unit (1:13); and the unit presents a substantial historical improbability - it is Othniel, whose landholdings were in the south of Israel, who confronts the king who is Israel's northern neighbor" ("The Book of Judges: Literature as Politics," JBL 108 [Fall, 1989]: 395-418, esp. 404). 
Nathan is a model for the producer of the text." 408 David is walking into a trap created by the narrator Nathan. ${ }^{409}$ Hearing the story of the rich man and the poor man ignites David's anger. Cleverly, Nathan offers no further comments or questions when ending the story, presenting a gap for David to fill. "David leaps into the unresolved gap between the rich man and the poor man in the story, appointing himself to the role of the just judge who will redress this imbalance, only to be told that the role he really plays is that of the unscrupulous oppressor." ${ }^{410}$ David's response to Nathan illustrates the dangers of filling in a gap. In spite of his skill in manipulating the stories of others, David's lack of self-awareness leads to his ensnarement in this narrative. The man who repeatedly escaped the clutches of Saul falls prey to a prophet's parable. ${ }^{411}$ David's desire to gain control of the story as a narrator who could rewrite its outcome led to his undoing. His inability to remain a reader of the story doomed him. No wonder the biblical narrator recognized the problems of theological presumptuousness and filled in certain gaps with obtrusions.

\footnotetext{
${ }^{408}$ Pyper, David as Reader, 6. Scholars also argue whether David should have recognized the genre of the parable as an allegory, parable, or fable. Andersson offers a nice discussion of the various theories (Untamable Texts, 113-15). In whatever way scholars define the genre, it seems clear that Nathan is seeking to elicit a response from David. Perhaps Robert P. Gordon is correct to call it a "judgmenteliciting" parable (1 \& 2 Samuel: A Commentary [Grand Rapids: Zondervan, 1986], 256-57).

${ }^{409}$ If Nathan knows the story of Nabal, then this trap is even more ingenious. Nathan inherently reminds David of Nabal's treatment of him and the death sentence David passed on the foolish man. See Fokkelman, Narrative Art, Vol. 2: 75.

${ }^{410}$ Pyper, David as Reader, 91.

${ }^{411}$ The character of David may also be very different at this point in the story. I am not suggesting that he has changed because of the narrator has created a composite portrait of him. Instead David may be different because he has achieved his goals and is no longer as wary as he was when he was running from Saul.
} 


\section{Conclusion}

This survey of David as a reader and writer of his own narrative offers more insights into the mindset of the Hebrew narrator. Perhaps not as manipulative as David, the biblical narrator nevertheless seeks to control the reader by skillfully anticipating the responses of the reader. David's narratives reveal the cunning involved in speaking and responding properly. Clever speakers like Nathan the prophet leave gaps that act as pits to ensnare their victims. Perhaps a recognition of the pitfalls that accompanied verbosity led the biblical narrators to be laconic in their writing. However, they also recognized the need to prevent readers from misinterpreting their words. Just as Joab anticipated the words of David in his report of Uriah's death, the biblical narrator often foresees the potential response of the reader. The books associated with the Deuteronomistic School are known as the Former Prophets. Hopefully, this study will produce a greater appreciation of their "prophetic" anticipation as they foresee reader responses and foreclose creative and theologically presumptuous interpretations with obtrusions.

Some of these obtrusions are more noticeable than others. Because break frames interrupt the plot, they draw attention to the work of the narrator. In contrast, non-break frame obtrusions occur after a cessation of action and are less obvious. Perhaps non-break frame obtrusions reveal more narrative skill than break frame obtrusions because the narrator strategically waits for a break in action before inserting the commentary necessary to promote a particular interpretation. However, it is also possible that some stories necessitate breaking frame at a particular juncture. If the narrator does not immediately intrude in the story, then the reader may begin working toward a conclusion that the narrator would find unacceptable. The obtrusive narrator limits the reader's 
power in both types of obtrusions, restricting the reader's control over the text by blocking undesired interpretations. 


\title{
CHAPTER V
}

\section{SELECTED EXAMPLES OMNISCIENT AND OBTRUSIVENESS}

\author{
IN ANCIENT NEAR EASTER LITERATURE
}

\section{Introduction}

In most literary studies, the concept of an omniscient narrator is taken for granted.

Scholars rarely feel the need to explain or define the term since the idea of an all knowing God serves as a convenient model for such a narrator. While some biblical scholars might question the extent of this deity's knowledge, the majority of literary critics define omniscience based on the totality of knowledge possessed by the infinitely wise God of Jewish and Christian tradition. ${ }^{412}$ Although philosophers and theologians may wrangle over definitions of omniscience, most narrative critics accept the literary presence of (1) the omniscient narrator and (2) God as an omniscient director. ${ }^{413}$ Infinite knowledge may be ascribed to this omniscient director. The omniscient narrator often appears to possess

\footnotetext{
${ }^{412}$ For an article questioning the total knowledge of the God of the Hebrews, see Michael Carasik, "The Limits of Omniscience," JBL 119/2 (2000): 221-32.

${ }^{413}$ Jonathan Culler writes about the assumptions that many literary scholars, including himself, make about omniscience: “'Omniscience' is a notion I have used in discussing narrative, without giving it much thought but also without having much conviction that 'the omniscient narrator' is a well-grounded concept or really helps account for narrative effects. Looking into the matter, I find this situation is not untypical. Critics refer to the notion all the time but few express much confidence in it. The idea of omniscience has not received much critical scrutiny" ("Omniscience," Narrative 12 [Jan. 2004]: 22-34).

For Barbara K. Olson's response to Culler, see "“Who Thinks This Book?' Or Why the Author/God Analogy Merits Our Continued Attention," Narrative 14 (Oct. 2006): 339-46. Olsen argues that "Culler's own resistance ... seems to me more theological than literary" (341). For Culler's response, see "Knowing or Creating? A Response to Barbara Olsen," Narrative 14 (Oct. 2006): 347-48. For Meir Sternberg's view of Culler's theories, see "Omniscience in Narrative Construction: Old Challenges and New," Poetics Today 28:4 (Winter 2007): 683-794. For Roland Barthes' view on the connection between God and the narrator, see Image-Music-Text (trans. Stephen Heath; New York: Hill \& Wang, 1977), 147-48.
} 
such knowledge as the narrator controls characters, actions, information, and time in the narrative. Ironically, the omniscient narrator of the Hebrew also controls the divine in narratives where God appears as a character and even knows the thoughts of God in primordial time (e. g. Gen 1). In spite of this power, the so-called omniscient narrator may have limitations. The fact that this narrator sometimes provides incorrect data or proves to have insufficient knowledge opens up the question of whether or not "omniscient" is a consistently appropriate label for this figure.

In the literature of the ancient Near East (ANE), deities seem to lack the complete knowledge of this idealized God. ${ }^{414}$ At times, ANE gods appear all knowing as they claim to read the thoughts of others and foretell coming events. At other times, these same gods display ignorance or "limited omniscience." While "limited omniscience" may seem like an oxymoron, the term accurately reflects the restricted knowledge of ANE gods.

Like ANE deities, narrators fluctuate between commanding hidden knowledge and displaying their lack of power. ${ }^{415}$ Indeed a god or narrator's greatest display of omniscience comes from the ability to know the thoughts of others. ${ }^{416}$ Knowledge of the

\footnotetext{
${ }^{414}$ ANE deities garner little consideration in many discussions of omniscience. In "On the Attributes of God," R. Pettrazoni describes Ea as "he who understandings everything"; but Pettrazoni begins the article by citing Xenophanes as the first person to describe God as omniscient in the sixth c. B. C. E. (Numen 2 [Jan.-Feb. 1955]: 1-27).

${ }^{415}$ Sternberg makes a similar argument in The Poetics of Biblical Narrative, "It is curious that literary scholars should refer to a superhuman viewpoint as an 'Olympian narrator,' for the model of omniscient narration they have in mind is actually patterned on the Hebraic rather than the Homeric model of divinity. Homer's gods, like the corresponding Near Eastern pantheons, certainly have access to a wider range of information than the normal run of humanity, but their knowledge still falls well short of omniscience, concerning the past as well as the future" (88).

${ }^{416}$ Culler argues that scholars should replace "omniscience" with "telepathy." He writes "“Telepathy' does have certain advantages, especially that of estrangement. 'Omniscience' may have become too familiar for
} 
inner life of characters is a prime example of omniscience since it represents the most hidden of knowledge. A narrator often moves the plot forward in pivotal ways by sharing a character's thoughts with readers. These omniscient comments prove more significant than simple asides that relate basic information to readers. The plot-moving impact of relating a character's thoughts through an omniscient comment reveals the power that narrators wield.

The narrator's voice manifests itself in different ways in ANE narrative traditions, including neutral omniscience, indirect free speech, general omniscience, first person asides, and obtrusions. These traditions reveal that obtrusions represent a significant stage in the development of omniscient thought. In neutral omniscience, the narrator assumes that the reader will follow the plot and, therefore, offers few explanations. In indirect free speech, the narrator's speech merges with the voice of a character. Narrators employ general omniscience to relate information to readers. First person narrators often provide asides, sharing information with readers that is hidden from characters in the narrative. In obtrusions, the thoughts of the narrators — not characters - appear on the page, affecting reader response. Just as the plot cannot continue without the narrator revealing the thoughts or intents of a character, narrators sometimes feel uncomfortable moving forward without making an obtrusive comment. ${ }^{417}$

In this presentation on omniscience and obtrusiveness in ANE literature, I connect the narrator with the gods by arguing three main points: (1) the limited omniscience of

us to think shrewdly about it (“Omniscience," 23). See also Nicholas Royle, The Uncanny (New York: Routledge, 2003), 261.

${ }^{417}$ Similarly, gaps may give readers pause. Some gaps may hinder readers from moving forward unless the narrator fills in a gap with a subsequent comment or the reader chooses to suspend disbelief. 
ANE deities may serve as a better paradigm for the narrator since these storytellers are not all knowing. (2) ANE narrators display different levels of omniscience and obtrusiveness, regulating the presence of their voice in the narrative based on how they envision themselves and their readers. (3) The narrator often behaves obtrusively by invoking divine favor, protecting a divine character or other celebrated figures, and in rare instances by challenging the gods.

\section{Objectives}

This chapter builds off my previous work on biblical omniscience and obtrusiveness by studying these features in the literary world of the ANE. The selected examples from diverse cultures can only be representative of this rich literature. Other and perhaps better instances of omniscience and obtrusiveness may lie in the vast volumes of this literature as well as in texts awaiting translation or discovery. This sampling of ANE literature begins with an analysis of the scribal culture of Hurro-Hittite literature; in particular, I examine the way these narrators hide behind neutral omniscience because they assume that the reader will readily follow the story being presented. Next, I turn to Ugarit where an emerging type of indirect free style evidences development of the narrator's voice as the narrator takes on the perspective of a character in a story. Because they wrote to a scholarly audience of insiders, Ugaritic narrators offered few explanations from an omniscient perspective. In both Hurro-Hittite and Ugaritic myths, the narrators shared the thoughts of the gods with readers, using the omniscient perspective to move the plot. Hebrew and Mesopotamian narrators did the same; but these narrators went further, creating obtrusions for a variety of reasons, 
including the following: (1) the divine became vulnerable and needed defending from a reader's unwelcome interpretations such as in Gen 22; (2) narrators of ancient Mesopotamian literature, such as Kabti-ilāni-Marduk of the Erra Epic, disagreed with the plan of the gods and openly challenged it through an obtrusion. The Mesopotamian narrators' belief that they had access to the secret knowledge of the gods led innovative scribes like Kabti-ilāni-Marduk to meld his voice with that of the gods and to act obtrusively. To finish this study, I turn to the autobiographical narrators of ancient Egypt and examine the first person asides they use to give insider status to the reader. These narrators cannot be considered obtrusive because of their first person perspective; however, they often behave similar to obtrusive narrators by breaking frame and invoking the gods in order to manipulate the reader. ${ }^{418}$

\section{Hurro-Hittite Myths}

\section{Hittite Deities}

Hittite and Hurrian myths reveal the restricted potential for omniscient and obtrusive comments in ancient narrative. ${ }^{419}$ Although wise, Hittite and Hurrian deities possessed limited omniscience. Billie Jean Collins points out that "the gods of the Hittites were conceived of in human terms ... The gods were neither omniscient nor omnipotent but made mistakes and were capable of being deceived. Still, they possessed a wisdom

\footnotetext{
${ }^{418}$ Later in this chapter, I consider the possibility that a first person narrative may have obtrusions in my discussion of Šulgi.

${ }^{419}$ For more on Hittite Literature, see Alfonso Archi, "Hittite and Hurrian Literatures: An Overview," in CANE 4:2367-77. See also Hans G. Güterbock, “A View of Hittite Literature,” JAOS 84 (Apr.-Jun. 1964): $107-15$.
} 
and power that was far above that of humans. The level of wisdom and power varied widely depending on each deity's status within the pantheon, which itself depended on the importance of the natural phenomenon that the deity represented." ${ }^{, 420}$ Rising from the syncretism of the ANE and Indo-European worlds, these gods often foiled each other and failed their subjects. ${ }^{421}$ Power shifts occurred as The Storm-God and the Serpent

[Illuyanka] reveals: "[Then] for the 'anointed they made the foremost gods the humblest, and the humblest they made the foremost gods." ${ }^{, 22}$ These changing dynamics in the world of the gods reflected real world events. ${ }^{423}$ Powers of the gods, like omniscience, remained limited, especially as contact with other cultures increased and made Hittite religion more intricate. ${ }^{424}$

\footnotetext{
${ }^{420}$ Billie Jean Collins, The Hittites and Their World (Archaeology and Biblical Studies 7; Atlanta: Society of Biblical Literature, 2007), 173-74.

${ }^{421}$ Collins, The Hittites, 174-78.

422 "The Storm-God and the Serpent [Illuyanka]," translated by Gary Beckman (COS 1.56:150-51). Beckman calls attention to "a basic belief of the Hittites" that "every deity and every human being has an essential role to play in the functioning of the universe (and in the microcosm of society), but the individual must remain in his or her proper station" ("Hittite and Hurrian Epic," in A Companion to Ancient Epic [ed. John Miles Foley; Blackwell Companions to the Ancient World, Literature and Culture; Malden, Mass.: Oxford: Blackwell Publishing, 2005], 255-63.
}

${ }^{423}$ See also Michel Mazoyer who writes of the anguish the departure of a deity created for the Hittites, noting that such shifts in power may reflect political realities (Télepinu, Le Dieu au marécage: Essai sur les mythes fondateurs du royaume hittite [Collection Kubaba, Série Antiquité 2; Harmattan; Paris: Association Kubaba, 2003], 113-15).

${ }^{424}$ Cem Karasu traces the history of Hittite deities, pointing out the culture's affinity for syncretism: “The Indo-European groups who came to Anatolia, instead of making the local people accept their cultural elements, adopted every element of these cultures that they found suitable. Therefore, the religious views of the Hittites became increasingly complex ("Why Did the Hittites Have a Thousand Deities?" in Hittites Studies in Honor of Harry A. Hoffner Jr. on the Occasion of His $65^{\text {th }}$ Birthday; [ed. Gary Beckman, Richard Beal, and Gregory McMahon; Winona Lake, In.: Eisenbrauns, 2003], 221-35). Karasu points out that the pantheon became "Hurrianised" in the thirteenth century, and "the identification of Hittite and Luwian deities with their Hurrian counterparts ... made possible a considerable reduction in the number of deities" (232). 
A study of Hittite literature reveals a great deal of borrowing, making uniquely Hittite literary contributions difficult to identify. In spite of this borrowing, Ahmet Ünal believes that the culture placed its literary signature on borrowed texts. ${ }^{425}$ Ünal praises Hurro-Hittite literature for drawing in readers, structuring texts, and contributing the "motif of child exposure" to the ANE world. ${ }^{426}$ He argues that a strong connection exists between Hittite style and readers, noting that Hittite "style is an attempt to involve the reader in the events being described so that the conclusion is seen as inevitable."427 This style may evidence Hittite use of neutral omniscience since the Hittite narrators designed their texts to illicit their desired responses from the reader. For example, The Disappearance of Telipinu explains the effect of Telepinu's absence on every part of nature. This situation offers a rather obvious bit of foreshadowing since readers can easily deduce that the return of Telepinu will make humans, plants, and animals fruitful again. $^{428}$

This use of neutral omniscience likely made obtrusions unnecessary even though the reworking of material probably created opportunities for intrusions. Although Ünal describes Hittite narrators as "first class literary exemplars," he notes that "the literary

\footnotetext{
${ }^{425}$ Ahmet Ünal, "Word Play in Hittite Literature," in Hittites Studies in Honor of Harry A. Hoffner Jr. on the Occasion of His $65^{\text {th }}$ Birthday (ed. Gary Beckman, Richard Beal, and Gregory McMahon; Winona Lake, In.: Eisenbrauns, 2003), 377-88. Contra: Gregory McMahon, "Hittite Texts and Literature," ABD 3: 228-31.

${ }^{426}$ Ahmet Ünal, “The Power of Narrative in Hittite Literature,” BA 52 (Je-S 1989): 130-43. For more on Hittite motifs and stylistic features, see Volkert Haas, Die hethitische Literatur: Texte, Stilistik, Motive (Berlin; New York: Walter de Gruyter, 2006).

${ }^{427}$ Ünal, "The Power of Narrative," 137.

428 "The Disappearance of Telepinu," (Harry A. Hoffner, Jr. Hittite Myths [ed. Gary M. Beckman: SBLWAW 2; Atlanta: Scholars Press 1990], 14-20).
} 
devices used by these authors were not of their own invention." ${ }^{429}$ In the end, the use of texts and deities from other cultures most likely arrested the development of a uniquely Hittite literature. But perhaps the Hittites narrators placed such great faith in their ability to effectively guide readers that they never felt the need to more fully develop their powers of omniscience.

\section{Hittite Scribes}

Hittite scribal policies also limited the omniscience of the narrators and quelled obtrusions. Like many of their ANE counterparts, Hittite scribes opposed the additions that could create narrative obtrusiveness. Quality control in the scribal production of texts also inhibited many redactions. This type of control related to the mastery that senior scribes had over texts. Junior scribes would probably have memorized texts in order to excel as copiers. ${ }^{430}$ They would have desired to accurately complete the work to please the senior scribes who supervised them. Such attention to detail may have precluded some narrative interruptions. Pihaziti, a Hittite scribe copying The Illuyanka Tales, states: "I am careful with regard to narratives. I have spoken this (truly)." ${ }^{431}$ Pihaziti not only revealed his diligence in the task at hand, but also his commitment to accurately depict

\footnotetext{
${ }^{429}$ Ünal, “The Power of Narrative,” 139.

${ }^{430}$ David Carr, Writing on the Tablet of the Heart: Origins of Scripture and Literature (Oxford; New York: Oxford University Press, 2005), 5. See p. 26 for more about Mesopotamian scribes.

431 “The Illuyanka Tales,” $\$ 35$ (A iv 24-28) (Harry A. Hoffner, Jr. Hittite Myths [ed. Gary M. Beckman: SBLWAW 2; Atlanta: Scholars Press 1990], 14).
} 
the words and stories of the gods. This concern for preserving a narrative's content and veracity occurs in other ancient literature. ${ }^{432}$

While junior scribes may have avoided narrative intrusions, priests may have added oral comments to texts that became part of the written record; and senior scribes may have inserted explanations. ${ }^{433}$ In the colophon of The Illuyanka Tales, Pihaziti states that he worked "under the supervision of Walwaziti, the chief scribe." ${ }^{434}$ Perhaps chief scribes and priests felt responsible not only for preserving texts, but also for preserving the ability of future readers to understand them. Their thoughts and interpretations could have become a part of texts through omniscient asides and on very rare occasions in obtrusions.

\section{Hittite Redaction}

Hittite and Hurrian texts come closest to narrative intrusions in their reworking of the Epic of Gilgamesh. Hittite scribes practiced copying the text, and "the Hittite capital has yielded more textual sources for Gilgamesh than are known from all other late Bronze Age sites combined." 435 In the Hittite language retelling of the Gilgamesh Epic,

\footnotetext{
${ }^{432}$ ANE monuments pronounced doom on desecrators. The Hebrew Bible warns against adding to the commands and words of God (Deut 4:2; Prov 30:6). The writer of Revelation admonishes others not to append prophecies to the text lest they face the plagues of the book (22:19). Such threats discouraged additional commentary but could not prevent it from occurring.

${ }^{433}$ In writing about Mesopotamian scribes, Carr notes that the most skilled scribes memorized their texts, incorporating them into new works and adding their own commentary (Writing, 36-37).

434 “The Illuyanka Tales,” $\$ 36$ (colophon of A), 14.

${ }^{435}$ Gary Beckman, "Gilgamesh in Hatti," in Hittites Studies in Honor of Harry A. Hoffner Jr. on the Occasion of His $65^{\text {th }}$ Birthday (ed. Gary Beckman, Richard Beal, and Gregory McMahon; Winona Lake, In.: Eisenbrauns, 2003), 37-57.
} 
Hittite scribes made several changes to Gilgamesh, adding new elements and explanations. For example, in the Hittite texts, Gilgamesh is created rather than born; and the Hittite narrators add their own gods to assist in the process. Although some scholars believe that the Hittites showed a lack of knowledge about other cultures in reworking ANE texts, they neglect to consider the fact that Hittite scribes adapted narratives for a culture heavily influenced by many societies. ${ }^{436}$ But even though they redacted many texts, their goals were not obtrusive.

Hurro-Hittite gods and narrators possessed limited omniscience. Both Hittite and other ANE literatures depict their gods as far from possessing all encompassing knowledge or "omniscience." Ancient texts frequently reveal limited knowledge, not only of the lesser deities but also of the more powerful gods. One example comes from a Hittite text of Hurrian origin. In The Song of Ullikummi, Kumarbi creates the seemingly invincible Ullikummi in an attempt to dethrone Teřšub, the king of the gods. The god Tasmisu displays lack of knowledge by wondering about the approach of the Sun God: "Why is the Sun God of the Sky, [King] of the Lands, coming? On what business does he come?"437 Tasmisu realizes the implications of the coming of the Sun God but lacks specific knowledge about the threat of Kumarbi. In another part of the text, the Irsirra

\footnotetext{
${ }^{436}$ Some scholars believe that the Hittites showed their lack of knowledge in reworking texts. For example, E. A. Speiser points to Hurrian and Hittite influence on the Kumarbi myth, noting that "there is nothing Hittite about this account save the language in which it is written" ("An Intrusive Hurro-Hittite Myth," JAOS 62 [Jun. 1942]: 98-102). Michael C. Astour argued that West Semites, and not Hittites, creatively reworked this myth. ("Semitic Elements in the Kumarbi Myth: An Onomastic Inquiry," JNES 27 [Jul. 1968]: 172-77). Both scholars credit others with the narrative artistry seen in this "Hittite" text.

437 “The Song of Ullikumi,” $\$ 25$ (A iv 41-48) (Harry A. Hoffner, Jr. Hittite Myths [ed. Gary M. Beckman: SBLWAW 2; Atlanta: Scholars Press 1990], 59). For a brief overview of Hittite deities, see Oliver R. Gurney, Some Aspects of Hittite Religion (Oxford; New York: Oxford University Press for the British Academy, 1977), 4-24.
} 
gods have no knowledge of why Kumarbi, the father of the gods, is calling them. ${ }^{438}$ However, it is unlikely that Kumarbi's position gave him superior knowledge since he attempts to overthrow Teššub.

The narrator possessed omniscient knowledge and shared it with the reader. With access to the inner thoughts of Kumarbi, the narrator moved the plot forward by showing the scheming of the god: "Kumarbi forms in his mind a clever plan, He raises an 'Evil [57] Day' in the person of a hostile man and makes hostile plans against Tessub." ${ }^{439}$ When Kumarbi creates Ullikummi to oppose Teššub's reign, the narrator relates Kumarbi's inner dialogue as he tries to protect his creation:

When Kumarbi had finished saying these words, he said to himself, "To whom shall I give this child? Who will [take] him and treat him like a gift? [Who ... ? Who will carry the child] to the Dark Earth? The Sun God of [the Sky and the Moon God] must not see him. Tessub, the heroic King of Kummiya, must not [see him] and kill him. Sauska, the Queen of Nineveh, the one of the ... woman, must not see him and snap him off like a brittle reed." 440

In this pivotal episode, Kumarbi actively hides knowledge from the other gods, concealing his fledgling weapon of destruction until Ullikummi matures. Through the narrator's omniscient comment, the reader knows what the gods do not.

In spite of these displays of narrative omniscience, Hittite and Hurrian texts are almost completely unobtrusive. ${ }^{441}$ The narrators may interrupt texts to insert ritualistic

\footnotetext{
438 “The Song of Ullikumi,” $\$ 16$ (C iii 9-19), 58.

439 “The Song of Ullikumi,” $\$ 2$ (A i 5-8), 56-57.

440 “The Song of Ullikumi," §13 (A iii 26-36), 58

${ }^{441}$ Ünal references texts in which narrators made their presence known by creating frames to move on to the next stories in a series ("The Power of Narrative," 193).
} 
material, such as explaining how to appease the wrath of a god. ${ }^{442}$ Rather than breaking frame, these intrusions reflect the form of the literature, revealing a strong connection between myth and ritual.

\section{Apology of Hattušili}

Nevertheless intrusive elements appear in the Apology of Hattušili. Similar to the Egyptians texts I will later discuss, this first person narrative shows how an individual protects himself and offers a nice comparison to the defenses third person narrators offer for favored characters. In his proclamation of innocence, Hattušili attempts to exonerate himself of any wrongdoing in order to justify his reign. He appeals to the divine to prove his inculpability. He proclaims himself innocent of usurpation by continually pointing to the goddesses Ištar as his patroness. ${ }^{443}$ Hattušili perhaps protests too much when he repeatedly states, "I did not do anything (evil) out of regard for the love of my brother." ${ }^{444}$ These self-serving declarations raise questions about his investment in an accurate rehearsal of events. ${ }^{445}$ However, the format of Hittite prayers may reveal why Hattušili spoke in such a way. Hittite prayers often addressed the gods as though the deities were presiding over a court case. Therefore the asides where Hattušili proclaims

\footnotetext{
${ }^{442}$ See "The Wrath of Telepinu," translated by Gary Beckman ( $\operatorname{COS} 1.57: 151-153$, A iv 4-7).

443 “Apology of Hattušili,” translated by Th. P. J. van den Hout, COS 1.77:199-204. For more on Hattušili’s reign, see H. Craig Melchert, "The Acts of Hattušili I," JNES 37 (Jan. 1978): 1-22.

444 "Apology of Hattušili," COS 1.77:199-204.

${ }^{445}$ For evidence of Hattušili's unreliability in explaining how he came to the throne, see Gary Beckman, "The Limits of Credulity," JAOS 125 (Jul.-Sep. 2005): 343-52. The Apology of Hattušili is often compared to David's attempts to distance himself from the death of Saul. See P. Kyle McCarter, Jr., "The Apology of David," JBL 99 (Dec. 1980): 489-504.
} 
his innocence were probably direct appeals to the gods. ${ }^{446}$ Perhaps the format of these prayers opened the door for omniscient commentary designed as responses to his detractors.

Throughout the text, Hattušili answers the charges of his critics. He anticipates a challenging question and crafts a reply: "If someone speaks thus: 'Why did you at first install him in kingship, but why do you now declare war on him in writing?' (I will answer:) 'If he had in no way opposed me, would they (i.e. the gods) really have made a great king succumb to a petty king?”447 Although Hattušili's powers of persuasion prove suspect because of his wordy protests, he recognizes the potential queries of his readers much like the obtrusive biblical narrator. He may have difficulty gaining the trust of his readers, whereas a third person biblical narrator gains the trust of the reader through terseness and only rarely interferes with an obtrusion. In spite of his dubious proclamations, Hattušili gives one last push to convince the reader through a succinct summary at the end of the Apology in which he provides the basic story of his rise to power and omits any hint of usurpation.

While failing to provide examples of obtrusiveness and generally lacking in intrusions, Hurro-Hittite myths offer a window into the world of the scribe and the potential development of omniscience and obtrusiveness. The Hurro-Hittite narrators' use of neutral omniscience reveals that they envisioned a reader who would recognize the flow of the story without asking questions or coming up with faulty assumptions. By

\footnotetext{
${ }^{446}$ See Itamar Singer, Hittite Prayers (ed. Harry A. Hoffner, Jr.; SBLWAW 11; Atlanta: Society of Biblical Literature, 2002), 5-11.

447 “Apology of Hattušili,” COS 1.77:3:54-79.
} 
acting as storytellers in the recitation of myths, priests may have introduced omniscient

comments, interjecting their own thoughts into the texts that scribes copied. Despite the

limitations placed on them, the scribes may have added their own commentary as well,

exhibiting omniscience and opening the door to obtrusiveness-even if they chose not to

walk through it.

\section{Narrative Poetry in Ugarit}

Ugaritic literature offers another portal into the world of the ancient narrator since

the destruction of the city, perhaps by the Sea Peoples, around 1200 B.C.E., has

preserved Canaanite stories such as Aqhat and Kirta. ${ }^{448}$ The baked tablets found in the

ruins of the ancient city of Ugarit illustrate the straightforward, matter-of-fact style of

narrative poetry produced by the society. This narrative poetry moved the plot with few

narrative comments. ${ }^{449}$

${ }^{448}$ Simon B. Parker discusses the value of Ugaritic literature in studying the ANE world in The Pre-

Biblical Narrative Tradition (SBLRBS 24; ed. W. Lee Humphreys; Atlanta: Scholars Press, 1989), $220-25$.

For information on the scribes of Ugarit, see the following: Anson F. Rainey, "The Scribe at Ugarit His

Position and Influence," PIASH 3 no. 4 (1968): 126-46; William J. Horowitz, "The Ugaritic Scribe," UF 11 (1979): 389-94. For more on the scribe Ilimilku, see Nick Wyatt, Religious Texts from Ugarit: The Words of Illimilku and his Colleagues; Sheffield: Sheffield Academic Press, 1998), 247; Nick Wyatt, Word of Tree and Whisper of Stone, and Other Papers on Ugaritian Thought (Gorgias Ugaritic Studies 1;

Piscataway, Nj.: Gorgian Press, 2007), 143; Otto Eissfeldt, Sanchunjaton von Berut und Ilimilku von Ugarit (Beiträge zur Religionsgeschichte des Altertums 5 (Halle [Saale]: N. Niemeyer 1952), 51.

${ }^{449}$ Wilfred G. E. Watson, “Abrupt Speech in Ugaritic Narrative Verse,” UF 22 (1990): 415-20. For more on style and other narrative features, see Jack M. Sasson, "Literary Criticism, Folklore Scholarship, and Ugaritic Literature," in Ugarit in Retrospect: Fifty Years of Ugarit and Ugaritic (ed. Gordon Douglas Young; Winona Lake, In.: Eisenbrauns, 1981), 81-98, esp. 93-95.

For a discussion of the connections between Ugaritic texts and Israelite religion and literature, see P. C. Craigie who points out that not all of the forms of literature were the same and that caution should be exercised in comparison ("Ugarit and the Bible: Progress and Regress in 50 Years of Literary Study," in Ugarit in Retrospect: 50 Years of Ugarit and Ugaritic [ed. Gordon Douglas Young; Winona Lake, In.: Eisenbrauns, 1981], 110-11). The divine council is one example of a shared type scene between Hebrew and Ugaritic cultures. See E. Theodore Mullen, Jr., The Divine Council in Canaanite and Early Hebrew Literature (ed. Frank M. Cross; HSM 24; Chico, Ca.: Scholars Press, 1980). 
Only in rare cases do readers observe the narrators making omniscient comments, perhaps reflecting the limited omniscience of the gods. Although at times knowledgeable, the gods often need information. They delight in receiving news, wonder when unexpected visitors approach them, and question why events occur. ${ }^{450}$ Similarly, Ugaritic narrators do not often exercise the narrative power of omniscience. They remain in the shadows but occasionally make their presence known to mark the passage of time or to provide etiological information to readers, such as explaining the origin of the dye murex. $^{451}$

\section{Indirect Free Style}

In spite of the scarcity of omniscient comments that reveal the narrator's voice, Frank Polak highlights the narrator's knowledge of the "inner life" of characters. Polak argues that Auerbach showed "that the ancient Israelite story-teller has a way to turn external features into the inner life of his heroes and heroines ... in particular by sophisticated changes and deviations in repetitious scenes, reports and announcements (command-execution-event report). In this manner he may also indicate his own attitude toward events and personages." Polak believes that "similar devices may be detected in the epic literature of the ancient Near East." 452 In particular, he points to "indirect free

\footnotetext{
${ }^{450}$ Marjo C. A. Korpel, A Rift in the Clouds: Ugaritic and Hebrew Descriptions of the Divine (UBL 8; Münster: Ugarit-Verlag, 1990), 153-54.

${ }^{451}$ For a study of the structure, themes, and functions of time in Ugaritic literature, see K. T. Aitken, "Formulaic Patterns for the Passing of Time in Ugaritic Narrative," UF 19 (1987): 1-10. For narrator comments on the origin of murex in the sea, see CAT 1.19:IV:41-43. CAT 1.1:III:1-2; CAT 1.1:IV:45-46.

${ }^{452}$ Frank Polak, "Some Aspects of Literary Design in the Ancient Near Eastern Epic" in kinnattū ša dārāti: Raphael Kutscher Memorial Volume (ed. A. F. Rainey; Tel Aviv: Tel Aviv Institute of Archaeology, 1993), $135-46$.
} 
style" which he defines as the narrator "representing the character's thoughts by means of objective, indirect speech forms: instead of the explicit quotation of the monologue one hears 'narrated monologue." ${ }^{9453}$ In these cases, the amalgamated voice of the narrator and the character are difficult to distinguish.

Referring to "indirect free style" as "indirect free speech" in his study of the nineteenth century European novel, Roy Pascal argues that the narrator embraces the thought world of the character, leading to "the mingling, even fusion, of two voices in a dual voice." ${ }^{454}$ This dual voice shows the thoughts of the character without the narrator invoking the standard phrase, "he/she thought to himself/herself." One of Pascal's examples reveals that an author may share the voice of a character even if the author disagrees with a character's beliefs. Pascal quotes the following passage from Daniel Deronda by George Eliot:

Gwendolen's dominant regret was after all she had only nine Louis to add to the four in her purse; these Jew dealers were so unscrupulous in taking advantage of Christians unfortunate at play! ${ }^{455}$

Eliot seemingly challenges Anti-Semitism in the novel, perhaps in attempt to show Jews how they should act in English society. She uses free indirect speech to reveal Gwendolen's prejudices. Pascal argues that this dual voices arises "in a state of intense imagination, when the writer so identifies with the creatures of his imagination that he

\footnotetext{
${ }^{453}$ Polak, "Some Aspects," 141.

${ }^{454}$ Royal Pascal also uses the German term "style indirect libre." (The Dual Voice: Free Indirect Speech and its Functioning in the Nineteenth-Century European Novel [Manchester, Eng.: Manchester University Press; Totowa, Nj: Rowan and Littlefield, 1977], 1-32, particularly 32).

${ }^{455}$ Pascal, The Dual Voice, viii.
} 
‘inwardly experiences’ what they experience.” ${ }^{456}$ Pascal discusses other examples in the works of Goethe, Austen, Dickens, Flaubert, and Dostoyevsky, as well as others.

In spite of the fact that indirect free style (free indirect speech) is a modern phenomenon far removed from ANE narrators, Polak argues that Ugaritic narrators were on the verge of this practice. These phenomena often occur in repetitions-such as when Kirta twice speaks of the scarcity of his progeny and the need for a wife. Polak argues that the narrator speaks the first time; but in the second instance, "the tale oscillates between the narrator's voice and Krt." ${ }^{457}$ In the first instance, the narrator directly provides information in the typically unobtrusive style of the Ugaritic narrator. In the second instance, the narrator begins as though looking down on Kirta and observing the scene. However, as the lines progress, Kirta's voice overtakes the narrator's descriptions. Now the narrator sees through Kirta's eyes rather than from a detached point of view. Were it not for the repetition of these lines, this emerging indirect free style might go unnoticed. Although not obtrusive, this example shows another way in which the narrator comes close to sharing the narrator's voice with the audience.

\section{Omniscience in Kirta}

Kirta also contains instances in which the revelation of a character's inner thoughts shift the plot. Kirta tells the story of a monarch who loses his children, marries again and has more offspring, only to be afflicted with an illness and be cursed by his heir

\footnotetext{
${ }^{456}$ Pascal, The Dual Voice, 22.

${ }^{457}$ Polak, "Some Aspects," 141. See CTA 14 I:10-14, 21-25. Polak also mentions instances of this phenomenon in Lugalbanda and in Gudea's dream.
} 
Yașșib. When Kirta desires more children after his first family dies, he receives a dream that tells him how he may acquire a wife to bear his future children. Kirta is eventually blessed with progeny, yet the goddess Asherah curses him with sickness for neglecting to honor a vow. ${ }^{458}$ The broken text appears to provide readers with insights into the divine, giving them a vision of Asherah's inner thoughts and speech as she plans to afflict Kirta. ${ }^{459}$ Kirta's illness not only threatens his life and his country, but also opens up the possibility that an heir will reign in his stead.

El intervenes by sending Shataqat to heal Kirta. During this time, Kirta's son Yașsib plots against his father. Again, the narrator relates a pivotal episode by giving readers access to the inner thoughts of a character. "Yassib, too, sits in the palace; / And his spirit instructs him. .." ${ }^{460}$ Readers observe the thought world of Yașșib as he plans to rebuke his father in an attempt to seize the throne. Yașșib, however, lacks the knowledge that Kirta's strength has returned thanks to the healing touch of Shataqat. He comes before his father and adds additional criticisms that do not appear in his thoughts. Yașșib extends his denouncement of his father by berating Kirta for his failure to care for the poor, orphan and widow. Yașșib’s inner thoughts move the plot in significant ways. When he acts on them in his speech, his father continues the cycle of woe by cursing him. Omniscience in Aqhat

\footnotetext{
${ }^{458}$ For warnings against neglecting a vow, see Deut 23:22-24 and Eccl 5:3-4. See Baruch Margalit, "K-RT Studies," UF 27 (1995): 215-315. Many scholars point to I Kgs 13:11-26 as parallel to Kirta.

459 “Kirta," CAT 1.15:III:25-30, translated by Edward L. Greenstein (Ugaritic Narrative Poetry, 27).

460 "Kirta," CAT 1.16:VI:25-26, 40.
} 
Although the thoughts and voice of the narrator occasionally enter the text, plots usually pivot on more significant information, such as the thoughts of a character. In Aqhat, Anat bargains with the title character in an attempt to gain possession of his bow. After the hero refuses to relinquish the weapon to Anat, rejects her offer of immortality, and speaks disrespectfully to the goddess, the narrator shares Anat's enraged thoughts with the audience: ${ }^{461}$

"Anat laughed out loud,

But inwardly she plotted [ ]:

'Come back, Aqhat the Hero,

Come back to me, [I will warn(?)]

you:

If I meet you in the path of rebellion, [Find you(?)] in the paths of pride, I will fell you under [my feet], Finest, cleverest of fellows!",462

In this text, the narrator shares information with the reader at a pivotal point. ${ }^{463}$ Readers hear the fury in Anat's thoughts, but Aqhat's lack of this knowledge costs him his life. ${ }^{464}$ The story reveals the danger of ignorance. The narrator's omniscient knowledge elevates the reader while the main character goes to his grave.

\footnotetext{
${ }^{461}$ In spite of the fact that Aqhat rejects immortality, Baruch Margalit sees evidence "of the epic poet's self-awareness as someone who effectively immortalizes the heroes of his poems." Similar to Gilgamesh, Aqhat lives on in the story that bears his name. (The Ugaritic Poem of Aqht, [Beihefte zur Zeitschrift für die alttestamentliche Wissenschaft 182; Berlin; New York: Walter de Gruyter, 1989], 305).

462 “Aqhat,” CAT 1.17:VI:41-45, translated by Simon B. Parker (Ugaritic Narrative Poetry, 62).

${ }^{463}$ Margalit sees narrative artistry in the handling of this "dramatic shift," recognizing that both Anat and the audience may find Aqhat's criticism of her as a woman humorous: "It is a mark of the poet(ess)'s consummate art that the general air of conviviality is maintained up to the very last moment, when Anat's deadly earnest attitude finds its expression in a blood curdling threat hurled at Aqhat" (The Ugaritic Poem of Aqht, 300).

${ }^{464}$ Bruce Louden discusses the problems mortals face when dealing with the gods, comparing the actions of the gods in Greek epic to both Aqhat and Gilgamesh ("The Divine Economy" in A Companion to Ancient Epic [ed. John Miles Foley; Blackwell Companions to the Ancient World, Literature and Culture; Malden, Mass.: Oxford: Blackwell Publishing, 2005], 91-104).
} 
An Unobtrusive and Artistic Narrator

Although the narrator uses the thought world of characters and gods to move the plot, no evidence of obtrusion occurs in Ugaritic texts. Simon B. Parker states, "The action in the Ugaritic stories is linear, moving forward without flashbacks or anticipations. The narrative world is never interrupted by authorial explanations, summaries, or judgments such as are common in biblical narrative." ${ }^{465}$ The oral delivery of the text may explain the lack of these elements since the performer could communicate directly with the audience through speech, tone, and gestures. Alternatively, Sasson notes that the narrator may have envisioned "a scribal audience rather than a listening one."466 As a result, the narrator placed certain rhetorical devices in the text "often imperceptible to a listening audience, which would delight a copyist or reader." ${ }^{467}$ With such an educated audience in mind, the narrator had little reason to obtrude. ${ }^{468}$

Obtrusions may also be absent from Ugaritic literature because the narrator envisions a knowledgeable reader who will accurately fill in gaps in order to make sense of the story. For example, the reader's ability to notice the implications of the presence or absence of light plays a major role in reader response in Kirta. Edward L. Greenstein

\footnotetext{
465 Simon B. Parker, "The Literatures of Canaan, Ancient Israel, and Phoenicia: An Overview," in CANE 4:2399-410. Edward L. Greenstein confirms the lack of intrusions: "there are, so far as I can recall, no addresses or asides to an audience, such as we find in some classical poetry as well as in a number of biblical texts" ("The Role of the Reader in Ugaritic Narrative," in "A Wise and Discerning Mind: Essays in Honor of Burke O. Long [ed. Saul M. Olyan and Robert C. Culley; BJS 325; Providence, Ri.: BJS, 2000] 139-151).

466 Sasson, "Literary Criticism,” 94.

${ }^{467}$ Sasson, "Literary Criticism," 94.

${ }^{468}$ For a few theories about narrative motive in Aqhat, see the following: Margalit, The Ugaritic Poem of Aqht, 485; Meindert Dijkstra, "Some Reflections on the Legend of Aqhat," UF 11 (1979): 199-210; Wyatt, Religious Texts, 247.
} 
argues that Kirta makes a vow to Asherah because he sees the gleaming eyes of her statue at sunrise and connects her image with the vision El gave him of his future bride. Darkness plays a key role later in the story. Kirta sends his son Ilha'u to bring his sister Thitmanit home. Not wanting his daughter to know of his illness, Kirta instructs Ilha'u to tell Thitmanit that he has come to summon her for a feast. When the sorrowful Ilha'u approaches his sister, he attempts to conceal his melancholy from his sister, arriving at night in order to prevent her from suspecting the infirmity of their father. However, his lance reflects the light, revealing his sad face. Greenstein observes, "just as Thitmanit had to deduce from her brother's tears that their father was ill, so does the reader need to deduce from Thitmanit's dismay that her brother's tears became visible. It is a simple inference, drawn from details that, I would contend, would not likely be there were they not to be interpreted. ${ }^{, 469}$ Greenstein argues that by filling in these gaps, the reader becomes "involved in the making of meaning." $" 770$ Therefore the Ugaritic narrators may avoid obtrusive comments because they prove unnecessary when writing to a scholarly audience. Additionally, the poetic form of the narrative may hinder obtrusiveness due to its systematic nature. ${ }^{471}$

Ugaritic narrators displayed artistry in their poems, not only in their subtle visual cues, as in Kirta, but also in setting scenes and expressing irony. Baruch Margalit draws attention to the masterful way the narrator sets up a touching scene where Thitmanit cares

\footnotetext{
${ }^{469}$ Greenstein, "The Role of the Reader," 148-50.

${ }^{470}$ Greenstein, "The Role of the Reader," 151.

${ }^{471}$ I am not arguing that it is impossible for obtrusions to occur in poetry. However, such obtrusions could prove more difficult and more noticeable if an intrusive narrator had to follow a poetic formula. In contrast, narrators can more easily insert their views into a prose text without worrying about meter or other poetic concerns.
} 
for her sick father. Margalit also notes the use of irony in Kirta: "To think that so many people and so many gods went to so much trouble, and risk, to produce a son and heir to K. in the image of Yașșib. How ironic, how sad, how funny." ${ }^{\text {"72 }}$ Although Kirta suffers the loss of his children and is later afflicted with an illness, he is comforted by the fact that his son can succeed him. And yet, when he returns to health, he discovers that all is not well. Yașșib desires to take the throne and rebukes his father, leading Kirta to curse the son in which he had so much invested. But the irony does not end there. Perhaps Kirta fails to realize that Yașșib is truly his father's son: "Kirta gets into trouble when he deviates from his divine instructions, and his older son plays with fire when he follows his own heart.. ${ }^{, 43}$ Both father and son make huge mistakes in their quests for power. According to Parker, both of them should realize that "it's a god's world—-beyond our control—and it is their rules by which the game of life is played." ${ }^{474}$ The Ugaritic narrators claimed to understand the divine world, but they also saw the humanity in Kirta and Yașșib and conveyed it to their readers. As masters of their craft, Ugaritic narrators not only skillfully move a plot forward, but they move the reader by stirring emotions.

\footnotetext{
${ }^{472}$ Margalit, "K-R-T Studies," 315. N. Wyatt also notes this irony, connecting the artistry to the scribe and priest Ilimilku, although whether he narrated the stories or was simply a copyist is still a matter of debate: "The irony is that it is Yasib who, through his rebelliousness (an equal impiety!), triggers off the final cataclysm. It might be objected that this is rather heavy stuff from a court poet! But it should be remembered that Ilimilku was also a priest. Perhaps he acted as moral theologian to the king, warning him with impunity of dangers, much as Nathan could be perfectly frank in his discourse with David (2 Samuel 12:1-15)" (Words of Tree, 152). Jack Sasson also notes the possibility that Ilimilku or Atanu created this literature, "albeit inspired by native lore" ("Comparative Observations on the Near Eastern Epic Traditions" in A Companion to Ancient Epic [ed. John Miles Foley; Blackwell Companions to the Ancient World, Literature and Culture; Malden, Mass.: Oxford: Blackwell Publishing, 2005], 223).

${ }^{473}$ Parker, Ugaritic Narrative, 11.

${ }^{474}$ Parker, Ugaritic Narrative, 11.
} 
In summary, Ugaritic literature leaves little room for omniscient comments and offers no evidence of obtrusion because the narrator envisioned a scholarly audience. In spite of the lack of obtrusions, the voice of the narrator enters the text through an ancient type of indirect free style. The narrators also move the plot at key points in the narrative, displaying omniscience by referencing the inner thoughts of gods and mortals. The narrators provide readers with essential information for understanding the motives of figures like Anat and Yașșib. As the characters make pivotal moves, the larger plot develops.

\section{Mesopotamian Literature}

Mesopotamian literature offers many omniscient comments, and a few obtrusions are also present. Although Sumerian and Akkadian literature, are distinct, I will discuss them together. Much of Mesopotamian literature originated with Sumerian texts which the Akkadians read, redacted, and disseminated throughout the ancient world, such as the Sumerian Inanna in the Netherworld which became the Descent of Ishtar into the Underworld in Akkadian. The Akkadians also preserved the Epic of Gilgamesh as well as the disputation form that arose in Sumerian literature. The Akkadians added their own unique tales to the literary corpus, such as Atrakhasis, Enūma Elish, and the Poem of Erra. They also worked with new genres that focused on wisdom, rulers, and "conduct and experience," as well as many others. ${ }^{475}$ Mesopotamian texts offer many insights into the concept of omniscience because the gods counsel with themselves in a way that

\footnotetext{
${ }^{475}$ Jean Bottéro, "Akkadian Literature: An Overview," in CANE IV: 2293-2303. See also Laurie E. Pearce, "The Scribes and Scholars of Ancient Mesopotamia," in CANE IV: 2265-78. See also Piotr Michalowski, "Sumerian Literature: An Overview," in CANE IV: 2279-91.
} 
parallels the thought processes of the narrator. Just as the gods mentally consider issues that affect the outside world, the inner thoughts of the narrators spill onto the page in omniscient comments and obtrusions, affecting reader response.

Intrusions in ancient Mesopotamian literature vary in degree and may be break frame or non-break frame obtrusions. Some seemingly intrusive elements do not break frame since they either follow the form of the text or complete its frame. In many genres, the narrators praise the gods at the end of texts; such veneration often occurs in Sumerian literature. Narrators also openly engage the audience by interjecting questions into their writing. While these queries reveal the narrator's presence in the text, they generally frame rather than break the frame of stories. Inana and $\breve{S} u-k a l e-t u d a$ contains the refrain, "Now, what did one say to another? What further did one add to the other in detail?",476 The narrator also employs questions to discuss bizarre scenes: "A plant growing in a plot like leeks, an oddity standing up like a leek stalk-who had ever seen such a thing before?"477 At other times, questions express wonder at the power and fury of the gods, "Who can compass the Asag's dread glory? Who can counteract the severity of its frown?" ${ }^{478}$ Additionally, the narrator employs questions to move the plot. For example, "What did Enlil do in order to decide the fate of mankind?" ${ }^{479}$ Such a question may

\footnotetext{
476 "Inana and Šu-kale-tuda," translated by Jeremy Black, et al. (The Literature of Ancient Sumer [Oxford: University Press, 2006], 198-200, 19-10, 13-14, 21-2, 40-1, 57-58, 89-90. The text is also framed by the statement, "But nowhere could she find the man who had sex with her." For more examples of intrusive questions, see "The Lament for Sumer and Urim," in Black, 127-41.

477 "Inana and Šu-kale-tuda," in Black, 199. The question is repeated several times with various oddities.

478 "Ninurta's Exploits," in Black, 165, 1. 44-45.

479 "Inana and Šu-kale-tuda," in Black, 200, 1. 94-5.
} 
reveal the oral background of the text as it seeks to understand the mind of the god Enlil. $^{480}$

Mesopotamian literature often employs the term "omniscient" to describe high gods like Enlil as well as deified humans like Šulgi. ${ }^{481}$ In the hymn "Šulgi and Ninlil's Barge," the narrator speaks of the wisdom and knowledge of Šulgi: "She entrusted it to the faithful provider, king Šulgi the shepherd, who is of broad intelligence and who will not rest day and night in thinking deeply about you. He, the wise one, who is proficient in planning, he, the omniscient one, will fell large cedars in the huge forests for you."482 The hymn "Šulgi the Favorite of the Gods" describes the king as "the omniscient one from birth" (142). ${ }^{483}$ The text associates Šulgi with extispicy and judgment since the next two lines state: "For the land he renders a firm judgment,/ For the land he obtains firms

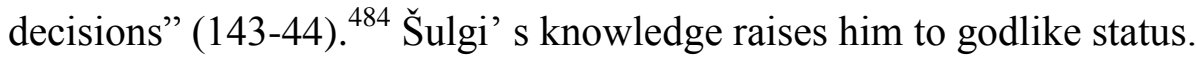

To share his exploits with future generations, Šulgi commissioned court poets to serve as ghost writers for him. As a result, the hymn Šulgi The King of the Road (Šulgi A) has obtrusive possibilities. Although the text uses the first person to give the appearance that Šulgi wrote the hymn, the poets act obtrusively to justify the king's claim

\footnotetext{
${ }^{480}$ Black et. al., The Literature of Ancient Sumer, 197-98.

${ }^{481}$ For more on the deification of Šulgi, see Jacob Klein, The Royal Hymns of Shulgi King of Ur: Man's Quest for Immortal Fame (Transactions of the American Philosophical Society, vol. 17, pt 7; Philadelphia: American Philosophical Society, 1981). See also Douglas Frayne who discusses the presence or absence of the "prefixed divine determinative" ("Šulgi the Runner" JAOS 103, no. 4 [Oct.-Dec. 183] 739-48, esp. 748.

482 "Šulgi and Ninlil's Barge," in Black, 114, 1. 4-6. The human Gudea possesses similar knowledge: "The true shepherd Gudea is wise, and able to realize things" (Black, 49). Similarly, David is described as an "angel of God" who possesses the power to discern situations (1 Sam 29:9. 2 Sam 14:17, 20; 19:27).

${ }^{483}$ Jacob Klein, Three Šulgi Hymns: Sumerian Royal Hymns Glorifying King Šulgi of Ur (Bar-Ilan Studies in Near Eastern Languages and Culture; Bar-Ilan: Bar-Ilan University Press), 145.

${ }^{484}$ Klein, Three Šulgi Hymns, 145. See also Jacob Klein, The Royal Hymns, 15-16.
} 
that he possessed super-human speed. According to Klein, "Fully aware of the incredibility of the claim that Šulgi accomplished such a long journey in one day (the distance between Ur and Nippur measured in a straight line exceeds a hundred miles), the poet, prior to the final hymnal epilogue, puts in Šulgi’s mouth the following concluding statement:

I truly did not praise myself (in vain)!

Wherever my eyes cast - there I go!

Where my heart prompts me-there I arrive!",485

Šulgi’s poet recognized a potential question from readers. In fact, they themselves may have doubted Šulgi's boast and realized that other readers would do the same. The texts that describe the greatness of Šulgi reveal the possibility of an obtrusion in a first person text, and they describe the omniscience of a deified human.

Other humans lack this knowledge, and the gods have different ideas on whether or not they should share their secrets with humanity. Marduk possesses knowledge that even the other gods cannot obtain. The Poem of the Righteous Sufferer describes Marduk's knowledge, declaring the god's omniscience: "Marduk divines the gods' inmost thoughts, / Which [god] understands his mind?" ${ }^{486}$ Wisdom texts like the Righteous Sufferer wrestle with humanity's inability to comprehend divine action. In the text, the Sufferer wonders how to please a god and how to understand the reasoning and intentions of the gods. ${ }^{487}$ For their part, the gods do little to aid human understanding. They even have different ideas about how much knowledge a god should share with

\footnotetext{
${ }^{485}$ Klein, The Royal Hymns, 15. For the complete translation, see Klein, Three Šulgi Hymns, 182-203.

486 "Poem of the Righteous Sufferer" in Benjamin R. Foster, From Distant Days: Myths, Tales, and Poetry of Ancient Mesopotamia (Bethesda, Md.: CDL Press, 1995), 301, I:31-36.

487 "Poem of the Righteous Sufferer," II:33-38.
} 
humans as the myth How Erra Wrecked the World illustrates. In the story, the god Erra believes that enlightening humans is a waste of time. ${ }^{488}$ However, Erra's counterpart and voice of reason, Ishum, shares a vision of Erra's destructive escapades with the scribe Kabti-ilāni-Marduk, who claimed not to have deleted or added a single line when he wrote it down. Ishum gave this scribe knowledge of the divine realm. When both humans and deities recite the poem, it will become an incantation that "will provide a needed defense against repetition" of Erra's actions. ${ }^{489}$

Alan Lenzi discusses the "history" created by ancient Mesopotamian scribes to explain how they possessed the secret of the gods. In order to connect themselves to the divine, these scribes had to traverse "the great chasm that exists between humans and the location of that [divine] knowledge." ${ }^{490}$ Human scribes found a way to explain how they acquired this secret knowledge by associating themselves with their "divine benefactor" Ea as well as the apkallü. ${ }^{491}$ These scribes created "the mythology of scribal succession" by tracing their lineage back to these ancient wise men who had a direct link with the gods. $^{492}$

Having forged this connection to the gods, these scribes wanted to control the secret knowledge that they received from the divine. Particularly, they wanted to deny

\footnotetext{
488 "How Erra Wrecked the World," in Foster, From Distant Days, 151, III: 65-69.

${ }^{489}$ Peter Machinist, "On Self-Consciousness in Mesopotamia," in The Origins and Diversity of Axial Age Civilizations (ed. S. N. Eisenstadt; SUNY Series in Near Eastern Studies; Albany: State University of New York Press, 1986, 183-202, especially 195.

${ }^{490}$ Alan Lenzi, Secrecy and the Gods: Secret Knowledge in Ancient Mesopotamia and Biblical Israel (SAAS XIX; Helsinki: The Neo-Assyrian Text Corpus Project, 2008), 247.

${ }^{491}$ Lenzi, Secrecy, 104-05.

${ }^{492}$ Lenzi, Secrecy, 107.
} 
access to their "vulgar 'colleagues' (i.e., the literate citizen and the scribe on the street). ${ }^{, 493}$ Lenzi argues that Mesopotamian scribes faced "a practical problem: how to keep the corpora containing the secret of the gods from prying eyes and non-authorized use." ${ }^{494}$ Therefore "certain tablets were restricted to authorized individuals." ${ }^{495}$ Such a practice lessened the need for the scribes to offer obtrusions because they were not attempting to explain meaning to someone unfamiliar with the world of the gods. Instead they tried to prevent such readers from ever encountering these secret texts.

In some instances, however, the narrators provided knowledge to aid reader understanding. Ninurta's Exploits explains the work of the gods: "since the gods of the Land were subject to servitude, and had to carry the hoe and the basket — this was their corvée work - people called on a household for the recruitment of workers." ${ }^{, 496}$ Other omniscient comments not only relay knowledge to readers but show irony as well. The Death of Urnamma describes how the passing of the king changed the city square: "Because of the fate decreed for Ur-Namma, because it made the trustworthy shepherd pass away, she was weeping bitterly in the broad square, which is otherwise a place of entertainment." ${ }^{, 497}$ This comment explains the power of the gods to change the normal flow of life, and the narrator wants readers to recognize this reversal.

\footnotetext{
${ }^{493}$ Lenzi, Secrecy, 147.

${ }^{494}$ Lenzi, Secrecy, 149.

${ }^{495}$ Lenzi, Secrecy, 149.

496 “Ninurta's Exploits" in Black, 171, 1. 337-38.

497 “The Death of Ur-Namma,” in Black, 57, 1. 17-19.
} 
Similar to the omniscient comments of their Hurro-Hittite and Ugaritic

counterparts, Mesopotamian narrators used the inner thoughts of both humans and gods to drive the plot. Lugalbanda and the Anzud Bird reveals the human hero's inner thoughts when Lugalbanda prepares to seek the favor of the bird: "In his heart he speaks to himself, 'I shall treat the bird as befits him, I shall treat Anzud as befits him." ${ }^{\text {"498 }}$ Later in the text, Lugalbanda seizes the opportunity to use his secret gift of speed when Enmerkar needs someone to return to Kalaba. The text reveals Enmerkar's feelings: "In their midst Enmerkar son of Utu was afraid, was troubled, was disturbed by this upset." ${ }^{499}$ Perhaps thoughts create pivotal episodes because they are similar to spoken language which often conveys the sense of drama to the audience. ${ }^{500}$ Omniscient comments about the inner thoughts of gods and humans prove essential to plot progression. ${ }^{501}$ Infrequently, the narrator acts obtrusively, providing additional—but not essential—information.

\section{Invasive Narration}

The narrators become more invasive in debates, often foreshadowing the winner by obtrusions which describe one of the participants in derogatory terms. At first, these

\footnotetext{
498 "Lugalbanda and the Anzud Bird," in Black, 23, 1. 5-7.

499 "Lugalbanda and the Anzud Bird," in Black, 28, 1. 63-64. Another example of the inner thoughts and feelings of a character occurs in Etana when the narrator describes the evil plotting of the eagle in order to put the bird in a position to meet the hero ("Etana, the King Without an Heir," II: 38-39).

${ }^{500}$ F. N. H. Al-Rawi and J. A. Black, “The Second Tablet of 'Išum and Erra," Iraq 51 (1989): 111-22.

${ }^{501}$ The narrator's mention of inner thoughts not only drives the plot, but also affects characterization by showing an individual's intentions. Gilgamesh and Huwawa reveals a slave's inner thoughts: "The slave, trying to ameliorate the situation, trying to make life appear more attractive, answered his master." Here, the slave recognizes his role and strategically interacts with his superior. ("Gilgameš and Huwawa," in Black, 346, 1. 96-97).
} 
intrusions seem minimal; however, the fact that they reveal the results makes them obtrusive. In The Debate Between Fish and Bird, the narrator reveals bias in describing the fish as hostile, quarrelling, overbearing, and insulting. The Heron and the Turtle describes the eventual loser with similar language. ${ }^{502}$ The narrator repeatedly refers to the bothersome nature of the turtle and even elaborates on its deficiencies. ${ }^{503}$ Although these examples make it appear as though this type of foreshadowing fits the form of debates, not every debate contains these elements. ${ }^{504}$

At other times, narrators intrude in texts by providing expansive explanations of mysterious subjects, such as sleep, dreams, or death. The narrator of Lugalbanda and the Mountain Cave offers extended commentary on sleep:

Sleep overcame the king-sleep, the country of oppression; it is like a towering flood, a hand like a brick wall knocked over, whose hand is elevated, whose foot is elevated; covering like syrup that which is in front of it, overflowing like syrup onto that which is in front of it; it knows no overseer, knows no captain, yet it is overpowering for the hero. And by means of Ninkasi's wooden cask, sleep finally overcame Lugalbanda. ${ }^{505}$

The narrator twice tells of sleep overcoming Lugalbanda, creating a frame that appears to house an extensive description of sleep but may break the frame of the story since the knowledge shared is unessential to the plot. ${ }^{506}$ As sleep overpowers the character, the

\footnotetext{
502 "The Heron and the Turtle" in Black, 237, 1. A48.

503 "The Heron and the Turtle" in Black, 238, 1. A90.

${ }^{504}$ See “The Debate Between Sheep and Grain” in Black, 225-29.

505 "Lugalbanda in the Mountain Cave" in Black, 19, 327-32.

506 "For more on Lugalbanda's dream, see H. L. J. Vanstiphout, "Reflections on the Dream of Lugalbanda (A typological and interpretive analysis of LH 322-365)" in Intellectual Life of the Ancient Near East: Papers Presented at the $43^{\text {rd }}$ Rencontre assyriologique international Prague, July 1-5, 1996 (ed. Jiří Prosecký; Prague: Oriental Institute, 1998), 397-412.
} 
narrator more forcefully enters the text. Rather than simply telling the reader that Lugalbanda slept, the narrator offers an elaborate description of this common event. Even though sleeping is technically an action, the nature of sleep interrupts the plot, opening the door for narrative commentary.

In the same section, the narrator discusses sleep and dreams, breaking into the text to distinguish between two purposes of sleep:

The king lay down not to sleep, he lay down to dream-not turning back at the door of the dream, nor turning back at the door-pivot, To the liar it talks in lies, to the truthful it speaks truth. It can make one man happy, it can make another man sing, but it is the closed tablet-basket of the gods. It is the beautiful bedchamber of Ninlil, it is the counselor of Inana. The multiplier of mankind, the voice of one not alive-Zangara, the god of dreams, himself like a bull, bellowed at Lugalbanda. Like the calf of a cow he lowed: Who will slaughter (?) a brown wild bull for me? ...

Lugalbanda awoke-it was a dream. ${ }^{507}$

The narrator frames the text by telling of Lugalbanda lying down to dream and then awakening from his reverie. The narrator breaks the frame of the story to provide an extended commentary on the nature of dreams.

Although sleep and dreams naturally create a break in action, these break frames reflect Mesopotamian interest in sleeping and dreaming. The Epic of Gilgamesh spends a great deal of time discussing the dreams of Gilgamesh and Enkidu. The dreams themselves - and not descriptions of the process of sleeping or dreaming - function in an omniscient manner since they foreshadow events in the story. For instance, Gilgamesh's need for sleep foreshadows his inability to attain immortality since sleep is a type of death. Gilgamesh's weakness to resist sleep ultimately proves that he is not completely

507 "Lugalbanda in the Mountain Cave" in Black, 19, 1. 36-50. 
divine. In the beginning of the text, the narrator describes Gilgamesh as "unsleeping ... by night and day." ${ }^{508}$ Gilgamesh's quest for immortality requires him to lose sleep through his travels and toil, and he eventually succumbs to exhaustion. Uta-napishti views Gilgamesh's slumber as a weakness, and tell his wife, "See the fellow who so desired life! / Sleep like a fog already breathes over him. ${ }^{, 509}$ Because Gilgamesh cannot overcome the human need for rest, he will ultimately sleep the eternal sleep of humanity, accepting the fate he so vigorously opposed..$^{510}$

The Prologue to the Standard Babylonian version of the Epic of Gilgamesh, however, reveals that monuments live on after death. The narrator directly addresses the reader, inviting the reader to "touch," "approach," and "climb" the fruits of Gilgamesh's labor. Through these apostrophes, the narrator obtrusively declares that Gilgamesh's architecture and even the man himself have no equal. The narrator also questions the reader about the quality of the masonry. Before the story begins, the narrator shares the narrator's opinions about Gilgamesh with the reader, behaving obtrusively in championing the cause of the man who sought immortality but succumbed to fate.

Although Mesopotamian narrators often discuss the unchangeable nature of fate, they wrestle with the issue just like Gilgamesh. The struggle manifests itself in questions such as those asked by the narrator of The Lament for Sumer and Urim who writes of Urim: "Its fate cannot be changed. Who can overturn it? It is the command of An and

${ }^{508}$ The Epic of Gilgamesh (translated by Andrew George; London; New York: Penguin Books, 1993), SV, Tab. 1, 1. 236-239, p. 9. Similarly, Enkidu remains awake while the other shepherds sleep (SV, Tab. 2, 1. 62, p. 14).

${ }^{509}$ Gilgamesh, SV, Tab. 9, 1. 213-14, p. 96.

${ }^{510}$ The narrator also elaborates on death in "When Ishtar went to the Underworld" (Foster, From Distant Days, 78-79, 1. 4-11). 
Enlil. Who can oppose it?" 511 When the gods change fate, narrators challenge the gods, becoming more obtrusive as they express their point of view. In "The Death of UrNamma," the narrator criticizes the divine for changing the king's fate, "Because An had altered his holy words completely, ... became empty, and because, deceitfully, Enlil had completely changed the fate he decreed. ${ }^{512}$ The narrator later returns to orthodoxy by contradicting the earlier statement about Enlil's deceit and accepts Ur-Namma's death, stating that "His appointed time had arrived, and he passed away in his prime." Although the narrator ultimately bows to the will of the gods, the narrator's intrusive nature cannot be ignored. ${ }^{514}$

\section{Kabti-ilāni-Marduk}

Perhaps Kabti-ilāni-Marduk, the scribe who claimed to have received a vision from Ishum, is the most obtrusive narrator in Mesopotamian literature. ${ }^{515}$ The scope of his narrative art involved switching person in his account of Erra's fury and obtruding in the text when he disagreed with the work of Ishtar and desired to attain God-like status.

\footnotetext{
511 “The Lament for Sumer and Urim” in Black, 130, 1. 56-57.

512 "The Death of Ur-Namma” in Black, 57, 1. 8-10. "A Sufferer's Salvation" deals with the inexplicable actions of the divine in first hurting and later healing (Foster, From Distant Days, 314-15).

513 “The Death of Ur-Namma” in Black, 58, 1. 50-51.

${ }^{514}$ David Damrosch argues that "for all the Mesopotamian emphasis on fate, historical texts could envision the gods as changing their minds and altering their plans for human events (The Narrative Covenant:

Transformations of Genre in the Growth of Biblical Literature [San Francisco: Harper \& Row, 1987], 58).

${ }^{515}$ Kabti-ilāni-Marduk's text was also popular as Peter Machinist notes, "The poem about the God Erra must clearly be reckoned one of the major texts of Mesopotamian religious literature, whether gauged by its content and literary artistry or by the evidence of its ancient popularity" ("Rest and Violence in the Poem of Erra" JAOS 103 [Jan.-Mar. 1983]: 221-26). For cross-cultural comparisons of Erra, see Attilo Mastrocinque, "The Cilian God Sandras and the Greek Chimaera: Features of Near Eastern and Greek Mythology Concerning the Plague," JANER 7 no. 2 (2007) 197-217.
} 
Marianna E. Vogelzang calls Kabti-ilāni-Marduk “a real external narrator,” referencing the way he "addresses Ishum in the second person" (lines 9, 19). ${ }^{516}$ In addition to showcasing his artistry by switching person, Kabti-ilāni-Marduk displayed his command of omniscience and revealed his obtrusive nature in How Erra Wrecked the World.

Kabti-ilāni-Marduk’s literary artistry and grasp of narrative omniscience shines forth in his portrayal of the inner life of the gods which he learns to reference from the Sumerian version of The Flood Story. Although The Flood Story relates that some gods lack knowledge, it states that "Ea took counsel with himself." ${ }^{, 517}$ In How Erra Wrecked the World, Kabti-ilāni-Marduk speaks of Erra's inner turmoil, relating how Erra's own counsel is defeated by his emotions: "He thought to himself what had been done, / His heart being stung, it could give him no answer, / But he asked it what it would have him do." ${ }^{518}$ Benjamin Foster states that "as read here, Erra is furious at what he regards as high-handed treatment, and, consulting only his own wounded feelings, decides to go on a rampage. The lines imply that he debated with his 'self,' but took guidance from his

\footnotetext{
${ }^{516}$ Marianna E. Vogelzang, "Patterns Introducing Direct Speech in Akkadian Literary Texts," JCS 42 (Spr. 1990): 50-70.

517 “The Flood Story," in Black, 214, C2-3. A similar idea may be expressed in Eph 1:11, "In him, according to the purpose of him who accomplishes all things according to the counsel of his will," (RSV). See also the Babylonian version of The Flood Story in which the narrator expounds on the lack of divine knowledge: "The house was surrounded, but the god did not know/ It was night, half-way through the watch, / Ekur was surrounded, but Enlil did not know!" ("Story of the Flood" in Foster, From Distant Days, 54, 1. 70-73).

518 "How Erra Wrecked the World," in Foster, From Distant Days, 147, II:110-112. Humans also counsel with themselves. In "Dialogue between a Man and his God," the young man says, "My Lord, I have debated with myself, and in my feelings / "[ ] of heart: the wrong I did I do not know!" (Foster, From Distant Days, 295, 1. 13).
} 
heart (= emotions) alone. ${ }^{, 519}$ When humans follow their hearts, the results often proves disastrous; but when a god follows his heart, cataclysmic ensues for Babylon. ${ }^{520}$

Machinist points out that the poem has "a certain introspective quality." ${ }^{\text {" }} 21$ When Erra thinks about his situation and favors the fury of his heart over reason, Kabti-ilāniMarduk invokes Erra's speech in an unusual manner. Foster writes, "This passage is unusual in Akkadian ... note that first person narrative is nearly always past or future, hardly ever renderable as present and in progress. Since the passage cannot logically refer to the future, and since the past is difficult for grammatical reasons, we have here a present, first-person narrative, one of Kabti-ilāni-Marduk's most interesting experiments. ${ }^{, 522}$ Far from being a ordinary copier of texts or a mere purveyor of the vision of Ishum, this scribe innovatively relates the story.

Later in the text, the pioneering Kabti-ilāni-Marduk switches to second person. Foster notes, 'Now Ishum narrates Erra's violent course in the second person, a literary experiment building upon the preceding." ${ }^{, 523}$ Kabti-ilāni-Marduk’s signature style reveals not only a gifted artist, but a narrator in full command of the possibilities of omniscience.

\footnotetext{
${ }^{519}$ Foster, From Distant Days, 147, n. 3. Gerfrid G. W. Müller discusses the characterization of the heart in Erra, noting that although it is not a human, a deity, or demon, it plays an significant role in the narrative and shows the inner life of Erra ("Wer Spricht? Betrachtungen zu 'Isum and Erra"' in Vom Alten Orient zum Alten Testament: Festschrift für Wolfram Freiherrn von Soden zum 85. Geburtstag am 19. Juni 1993 (ed. Dietrich Manfried and Oswald Loretz; AOAT 240; Kevelaer: Verlag Butzon \& Bercker; NeukirchenVluyn: Neukirchener Verlag, 1995), 349-60.

${ }^{520}$ Nels M. Bailkey discusses how humans following their own hearts led to these events (“A Babylonian Philosopher of History" Osiris 9 (1950): 106-30. esp., 119-20).

${ }^{521}$ Machinist, “On Self-Consciousness,” 192-95.

${ }^{522}$ Foster, From Distant Days, 146.

${ }^{523}$ Foster, From Distant Days, 151.
} 
How Erra Wrecked the World reveals Marduk's limited omniscience when he speaks to Erra: "O warrior Erra, concerning that deed / you said you would do." ${ }^{, 524}$ Here, Marduk, quoting Erra, shows that he knows of Erra's inner plotting: "I will make Marduk angry, stir him from his dwelling, / and lay waste the people!"'525 Nevertheless Marduk's later actions bring his omniscience into question. He knows the secret thoughts of Erra, but knowledge of the disastrous future evades him. As a result, Kabti-ilāni-Marduk must explain Marduk's absence from the city and the subsequent aggression against it. ${ }^{526}$

First, however, Kabti-ilāni-Marduk obtrudes in the text, providing what is perhaps the historical context for the poem when describing the attack of the Sutaens on the men who worshipped in the cult of Ishtar: ${ }^{.27}$

As for Uruk, the dwelling of Anu and Ishtar, the city of courtesans, harlots, and prostitutes (for the cult), Whom Ishtar deprived of husbands and reckoned as her own(?), There Sutaean nomads, men and women, bandy war whoops!

They turned out the actors and singers (of) Eanna, Whose manhood Ishtar changed to womanhood to strike awe into the people, The wielders of daggers and razors, vintner's shears and flint knives, Who take part in abominable acts for the entertainment of Ishtar, ${ }^{528}$

\footnotetext{
524 "How Erra Wrecked the World," in Foster, From Distant Days, 139, 1. 132-33.

525 "How Erra Wrecked the World," in Foster, From Distant Days, 138, 1. 123-24.

${ }^{526}$ The conflict that arises when Marduk leaves Babylon may reflect political instability. This connection between theomachy and politics may also be seen in the conflicts between Baal and Yam in Ugaritic literature as well as in Marduk's battle with Tiamat.

${ }^{527}$ Daniel Bodi dates the Poem of Erra to around 750 BCE, arguing that the Kabti-ilāni-Marduk wrote the poem after the Sutû invasions (The Book of Ezekiel and the Poem of Erra [OBO 104; Freiburg, Schweiz: Universitätsverlag; Göttingen: Vandenhoeck \& Ruprecht, 1991] 54-5).

528 "How Erra Wrecked the World" in Foster, From Distant Days, 156, 1. 53-59.
} 
Foster notes that these men may have served as cult prostitutes and engaged in selfmutilation. ${ }^{529}$ He believes that these "practices may have been abhorrent to the poet.",530 The poet could have simply ended this notice with the destruction of these individuals, and the text would not have suffered from the deletion. The narrator intrudes in the text to provide his own commentary and perhaps show his displeasure for what the goddess Ishtar had done. The obtrusion seems ironic since the poet complains about the actions of the goddess Ishtar that are confined to her cult when the god Erra is wreaking havoc on the world. But perhaps it is not surprising that an artistic narrator who experimented with changing person throughout the text showed himself to be an obtrusive narrator.

His obtrusive nature, however, does not end with his objections to the cult of Ishtar. At the end of the text, he appears to take on the attributes of the god. Foster notes that "Erra's speech melds into that of the narrator." 531 The text reveals the narrator's greatness and arrogance: "In the sanctum of the learned, where they shall constantly / invoke my name, I shall grant them understanding." 532 Kabti-ilāni-Marduk intrudes in the text, not only for the sake of providing understanding through omniscience, but also to express his opinion and champion his fame in an obtrusive manner.

\footnotetext{
529 "The cult of Ishtar was associated with prostitution, both male and female (lines, 52, 56), and, perhaps, self-mutilation (57)" (Foster, From Distant Days, 156, n. 2).

${ }^{530}$ Foster, From Distant Days, 153. Kabti-ilāni-Marduk is opposed to violence throughout the poem. In Akkadian Literature of the Late Period, Foster views the poem as "condemnation of civil strife as a violation of the cosmic order" (ed. Eckhard Frahm and Michael Jursa; Guides to the Mesopotamian Textual Record 2; Münster: Ugarit-Verlag, 2007), 66-67.

${ }^{531}$ Foster, From Distant Days, 163.

${ }^{532}$ Foster, From Distant Days, 163, V:56-57.
} 
Daniel Bodi compares Kabti-ilāni-Marduk to the Deuteronomist since both describe the destruction of a city and create "a theology of history" to explain why a city's deity abandoned an area. ${ }^{533} \mathrm{He}$ argues that "Kabti-ilāni-Marduk was not just a compiler. Rather the scribe offered a creative synthesis of ancient Mesopotamian traditions applying them to a particularly difficult situation in the history of Babylon." David Damrosch further strengthens the ties between the Babylonian scribe and the Hebrew scribal school. He believes that Kabti-ilāni-Marduk wanted to avoid stating that Marduk had suffered defeat at the hands of other gods. Therefore he responded to “religious doubts" by explaining Marduk's absence just as the Deuteronomistic School explained why Yahweh left Jerusalem. ${ }^{535}$ The deities abandoned their respective cities because their people had abandoned them.

In commenting on Kabti-ilāni-Marduk’s artistry and omniscience, Sternberg references the evolution of narration from "God inspired" to "God-like." Kabti-ilāniMarduk reflects both in his writings. ${ }^{536}$ He reports that the god Ishum inspired him and told him exactly what to write; however, his artistry and ease in assuming the voice of the gods and claiming to know their thoughts makes his narration God-like. In the end, Kabti-ilāni-Marduk displays not only creative tendencies, but also a penchant for obtrusions. Kabti-ilāni-Marduk was an experimenter who exercised great control over his

\footnotetext{
${ }^{533}$ Bodi, The Book of Ezekiel, 61-62.

${ }^{534}$ Bodi, The Book of Ezekiel, 57.

${ }^{535}$ Damrosch, The Narrative Covenant, 76.

${ }^{536}$ Sternberg, "Omniscience in Narrative Construction," 708.
} 
texts. He proves that obtrusiveness does not negate narrative artistry. ${ }^{537}$ In some cases, the two may go hand-in-hand.

\section{A Negative Obtrusion in The Poor Man of Nippur}

In contrast to the obtrusive manner of Kabti-ilāni-Marduk's writing, some scribes acted more like oral storytellers when they dealt with reader questions created by gaps. Somewhere between obtrusions and gaps lies what I call a negative obtrusion. A negative obtrusion occurs when a narrator recognizes a substantial gap that almost all readers will question. Although such a question will probably not lead to an unacceptable interpretation, the story cannot successfully continue until the narrator deals with this issue. The narrator fills in the gap with information for the sole purpose of keeping the plot moving. The narrator's actions are intrusive, but the information shared is hollow because it lacks substance. In a negative obtrusion, the narrator calls on the reader to suspend disbelief for the sake of advancing the story. While regular obtrusions shape a reader's answer to a question, negative obtrusions eliminate questions.

A negative obtrusion occurs in the Akkadian folktale The Poor Man of Nippur. In the story, the poor man Gimil-Ninurta vows revenge on a mayor after the official mistreats him. The tale opens with an unhappy Gimil-Ninurta planning to buy a ram with the money he gains from selling his meager wardrobe: "He took counsel with his wretched heart, / 'I'll strip off my garment, for which there is none to change, / I'll buy a

\footnotetext{
${ }^{537}$ For more examples of narrative artistry in Erra and other Mesopotamian literature, see Foster, Akkadian Literature of the Late Period, 66-67. See also Damrosch, The Narrative Covenant, 69-70.
} 
ram in the market of my city, Nippur." "538 The narrator continues to relate GimilNinurta's thoughts, and later Gimil-Ninurta explains his reasoning to the mayor. He has brought the goat in the hope that the mayor will provide beer for a feast. The mayor gives the poor man bad beer and the worst parts of the meat before expelling him. GimilNinurta then plots his threefold revenge on the mayor, a pledge that incites laughter in the politician.

Gimil-Ninurta's first scheme involves masquerading as a royal courier charged with delivering gold to the temple of Enlil. To pull off the ruse, he negotiates the one day rental of a chariot from the king. After his request, the negative obtrusion appears in the text:

Gimil-Ninurta came before the king, He prostrated and did homage before him, "O noble one, prince of the people, king whom a guardian spirit makes glorious Let them give me, at your command, one chariot, That, for one day, I can do whatever I wish, For one day my payment shall be a mina of red gold." The king did not ask him, "What is your desire, That you [will parade about] all day in one chariot?"539

The narrator anticipates that the reader will wonder how this poor man could successfully bargain with the king. The reader may even believe that the king will laugh at GimilNinurta rather than grant his request. The narrator negates this possibility and others by intruding in the text. Readers never hear that the king felt sorry for the man, found himself persuaded by the poor man's speech, or saw the comic possibilities in a poor man

\footnotetext{
538 “The Poor Man of Nippur,” in Foster, From Distant Days, 357, 1.16.

539 “The Poor Man of Nippur,” in Foster, From Distant Days, 359, 1. 72-80.
} 
parading around in a chariot. The narrator glosses over the issue through the use of a negative obtrusion.

Although the king never asks Gimil-Ninurta how he will pay the one mina fee for the chariot, the answer comes when the reader later sees the poor man tricking the mayor out of two mina and feasting on his sheep. The narrator relies on the reader to make this connection. The two minas explain how the poor man affords the chariot, and the negative obtrusion offers a hollow reason to explain how he succeeded in making this deal in the first place.

The negative obtrusion eliminates a reader question without providing a real answer. This type of obtrusion fills in the gap by serving as a place holder with no value. Perhaps the comment arose from oral tradition when the storyteller eliminated the need to explain the scene by thinking out loud. The thoughts of the storyteller bled onto the text and affected reader response — negating a reader's questions rather than obtrusively shaping the reader's opinion.

\section{Egyptian Literature}

Like their ANE neighbors, Egyptians move the plot by relating a character's inner thoughts and by showing how individuals wrestle with fate. Egyptian narrative constructions also reveal a strong desire to shape stories through readily recognizable frameworks. Stories such as The Doomed Prince and The Shipwrecked Sailor actively utilize frames to shape the plot. The narrator creates these frames through the use of repetitive language and omniscient comments that convey the narrator's awareness of time to the reader. These texts also reveal the influence of biography on Egyptian 
literature. ${ }^{540}$ In spite of the overarching use of third person in these tales, the Sailor, the Snake, and the Prince all utilize first person point of view to share their back stories with other characters and readers. ${ }^{541}$

\section{Egyptian Artistry}

While Egyptian narrators display literary artistry and the use of first person asides, Hans Ulrech Gumbrecht points out that Egyptologists show little concern for literary aspects. He notes that "no specific concept of literature, implicitly or explicitly, plays a role in Egyptology." 542 An examination of the narrator's relationship with the reader reveals narrative artistry in Egyptian literature. Galán believes that vagueness contributes to narrative artistry because "seeking the participation of the receiver in the personal recreation of the tale" builds "bonds of complicity between the author and the public.” Therefore Galán thinks that "its abstract character" makes The Shipwrecked Sailor a classic. ${ }^{543}$ Galán further argues that "the author is an artist in that he applies and develops aesthetic criteria in his work and uses a complex and personal code to communicate with his audience." ${ }^{544}$ In this sense, The Shipwrecked Sailor and Sinuhe are

\footnotetext{
${ }^{540}$ For a discussion of genre in Egyptian literature, see Richard B. Parkinson, "Types of Literature in the Middle Kingdom," in Ancient Egyptian Literature (ed. Antonio Loprieno; Leiden; New York; Köln: E. J. Brill, 1996), 297-312.

${ }^{541}$ See Donald B. Redford, “Ancient Egyptian Literature: An Overview” in CANE IV: 2223-2241.

${ }^{542}$ Hans Ulrech Gumbrecht "Does Egyptology Need a 'Theory of Literature'?” in Ancient Egyptian Literature (ed. Antonio Loprieno; Lieden; New York; Köln: E. J. Brill, 1996), 3-18, esp. 7. Additionally, Antonio Loprieno discusses the fact that many Egyptologists no longer desire to dialogue with ANE scholars ("Defining Egyptian Literature," in Ancient Egyptian Literature [ed. Antonio Loprieno; Lieden; New York; Köln: E. J. Brill, 1996], 39-58, esp. 39).

${ }^{543}$ Galán, Four Journeys, 48.

${ }^{544}$ Galán, Four Journeys, 94.
} 
works of art. ${ }^{545}$ Although both attempt to influence reader response through first person asides, these asides do not eclipse narrative artistry. In fact, they reveal that the narrator manipulates the reader by raising the reader's status. While the Ugaritic narrators wrote to an audience of insiders, the Egyptian narrators of first person popular tales gave the audience insider status by sharing specific information with them.

Setting also conveys a great deal of information to readers since the environment plays a significant role in the Egyptian literary world. Although setting influences the literature of all civilizations, the effect on Egyptian texts seems particularly pronounced since geography influenced cultural conceptions of the afterlife. In this unique geographical setting, the dry environment that preserved bodies through desiccation increased interest in preserving remains and stories. Setting has a significant effect on reader response to ancient Egyptian literature since many stories deal with returning home. The inherent tension created when Egyptians leave their native land heightens the drama in these stories since expatriate or traveling Egyptians risked losing out on the afterlife. Reader conceptions of home increase empathy for characters like Sinuhe who attempts to return home for burial after fleeing to a foreign land.

\section{The Tale of Sinuhe}

The Middle Kingdom (1980-1630) narrative The Tale of Sinuhe shows the power of hidden and disclosed knowledge. As a first person autobiography, the story provides a window into the protagonist's inner thoughts as he recounts his plight of leaving Egypt in

${ }^{545}$ Galán, Four Journeys, 94. 
panic and haste. ${ }^{546}$ Although Sinuhe's comments may seem less suspicious than those of Hattušili because he cleverly manipulates reader response, his multiple explanations about his departure may lead readers to question his story. Sinuhe attempts to win the sympathy of his readers by drawing them into the perplexing situation he faced. The death of King Amemenhet, perhaps in a harem conspiracy, apparently led Sinuhe to leave his homeland. ${ }^{547}$ Sinuhe fled Egypt, fearing the political treachery engulfing the land. He offers several reasons for his swift departure from Egypt. He tells the ruler of Upper Retenu of the Pharaoh's death, noting that "one did not know the circumstances." aside the reader, Sinuhe states, "But I spoke in half-truths." ${ }^{, 549}$ As the teller of the tale, Sinuhe controls the flow of information. While his comments to the king may potentially be unreliable and deceptive, he is hyper reliable to the reader, elevating the reader's status above the king by sharing intimate information.

Sinuhe attempts to draw the reader onto his side by leaving gaps concerning the events surrounding his flight, as José Galán observes: “the author sketches . . . an

\footnotetext{
${ }^{546}$ For more on the history of Sinuhe, see Jochem Kahl who argues that The Tale of Sinuhe was handed down in three different traditions in the Middle Kingdom ("Es is am anfang bis zum Ende so gekommen wie es in der Schrift gefunded worden war," in "Und Mose schriebe dieses Lied auf": Studien zum Alten Testament und zum Alten Orient: Festschrift für Oswald Loretz zur Vollendung seines 70 Lebensjahres mit Beträgen von Freunden, Schülern und Kollegen [AOAT 250; Münster: Ugarit Verlag,1998] 385-400, esp. 398). Alan H. Gardiner discusses speculation that the "nucleus" of Sinuhe "may be derived from the tomb of a real Sinuhe, who had a life of adventure in Palestine and was subsequently buried at Lisht." However, he notes that "we should doubtless find that literary elaboration had greatly changed the expression and the character of the original narrative" (Notes on the Story of Sinuhe [Librairie Honoré Champion, 1916; Photocopy, La Cross, WI.: Brookhaven Press, 2002], 168).

${ }^{547}$ See "The Instructions of King Amenemhat I for His Son Sesostris I" for details of his death (AEL 1:13539).

548 "The Story of Sinuhe" (AEL 1:225).
549 "The Story of Sinuhe" (AEL 1:225).
} 
ambiguous atmosphere." ${ }^{, 550}$ Even as Sinuhe appeals to the audience to interpret his plight, he manipulates reader response in many ways, including referring to official documents. ${ }^{551}$ More persuasively, Sinuhe appeals to the reader's humanity, and the reader comes to view Sinuhe as "a victim of circumstance and of his human condition." Sinuhe is not a king, readers may identify with his situation, accepting his explanations more readily than those of a powerful monarch like Hattušili. As a ruler, Hattušili manipulates reader response through a rhetoric backed by royal authority. As a servant of the king, Sinuhe merely relies on the power of words. ${ }^{553}$

Sinuhe is both a propagandist and a subversive. Richard B. Parkinson proposes that these competing roles add an artistic touch to the narrative: "The interpretive problem posed by the fusion of the two contraries of conformist and individualist, propagandist and subversive, is not unique to Egyptian literature, and such features are generally seen as a sign of artistic value in western literature. ${ }^{, 554}$ However, Parkinson also believes that the framework of the story artistically sets appropriate limits around Sinuhe's subversiveness in order to regulate him. Parkinson compares the framework of literature to an encircling spell in magic conjured for the purpose of binding the

\footnotetext{
550 José Galán, Four Journeys in Ancient Egyptian Literature (Lingua Aegyptica; Studia mongraphica 5; Göttingen: Seminar für Ägyptologie und Koptologie), 78.

${ }^{551}$ See Richard B. Parkinson "Individual and Society in Middle Kingdom Literature," in Ancient Egyptian Literature (ed. Antonio Loprieno; Lieden; New York; Köln: E. J. Brill, 1996), 137-55.

552 Galán, Four Journeys, 78.

553 The tale may even serve a didactic function "to summon an answering mood of self-examination in the audience" (Parkinson, "Individual and Society," 146). See also John Baines, "Interpreting Sinuhe," The Journal of Egyptian Archaeology 68 (1982): 31-44.

${ }^{554}$ Parkinson, "Individual and Society," 152.
} 
unacceptable and making it palatable to an audience. ${ }^{555}$ However, the reader may wonder if Sinuhe's asides will break the spell.

In spite of his potentially dissident status, Sinuhe strives to win the favor of audiences by gaining their sympathy. He offers another reason for his exfiltration: "I believed there would be turmoil and did not expect to survive it." ${ }^{, 556}$ Even encountering a stranger on the road incites panic in Sinuhe. Only the fear of dying outside of Egypt overshadowed Sinuhe's fear of Sesostris the son of Amemenhet. Therefore he appeals to the king to allow him to return home.

Ultimately, Sinuhe reasons that his predicament arose from a fate decreed by a god: "I do not know what brought me to this country; it is as if planned by a god. As if a Delta-man saw himself in Yebu, a marsh-man in Nubia."557 According to Sinuhe, the power of the gods shines forth in their ability to control information that humans lack, "Is there a god who does not know what he has ordained, and a man who knows how it will be?" 558 In addressing readers and Sesostris, Sinuhe emphasizes his contention that a god caused him to flee. Sinuhe works hard to remove any measure of culpability. The god

\footnotetext{
${ }^{555}$ Parkinson, "Individual and Society," 154.

556 "The Story of Sinuhe" (AEL 1:224). Max Pieper argues that Sinuhe had two good reasons for fleeing: (1) if the present king and his heir are lost, then Sinuhe is in trouble (2) even if the king or his heir survives, Sinuhe may suffer the mistrust that will certainly follow the attempted overthrow (Die Ägyptische Literatur [Handbuch der Literaturwissenschaft; Wildpark-Potsdam: Akademische verlagsgesellschaft Athenaion, 1928], 39).

557 "The Story of Sinuhe" (AEL 1:225).

558 "The Story of Sinuhe" (AEL 1:227).
} 
planned his departure; but all of Sinuhe's actions show that for him the entire situation "was unplanned."559

When Sesostris pronounces his verdict on Sinuhe, he states, "This matter-it carried away your heart. It was not in my heart against you. ${ }^{, 560}$ Sesostris believes that Sinuhe left Egypt because of false fears. The heart of Sinuhe led him to believe that Sesostris would plot in his heart against him, but that was not the case.

Sinuhe shows how a character manipulates others by invoking the divine as a defense. Sinuhe breaks the frame of the narrative by providing different points of view, attempting to influence the response of both Sesostris and the audience. Similar to obtrusive narrators who use the divine to explain away difficult situations, Sinuhe discovers that his greatest ally for exoneration is not in Upper Retinu or Egypt but dwells in the realm of the gods. As a first person narrator, Sinuhe can defend himself and control what others say about him. In contrast, a character in a third person narrative often has less power. Therefore the narrator of a third person story may obtrude to protect a character.

Even though he addresses readers in the first person, Sinuhe's multiple reasons for his flight may lead readers to question him since he continually insists he is innocent. Although his story contains a frame, Sinuhe shows evidence of intrusiveness, breaking the frame by providing inconsistent information. When he befriends the ruler of Upper Retinu, he states that the alliance resulted because the ruler "knew my character and had

\footnotetext{
559 “The Story of Sinuhe” (AEL 230-31).

560 “The Story of Sinuhe” (AEL 1:229).
} 
heard of my skill, Egyptians who were with him having borne witness for me." Sinuhe controls the flow of this information and provides a plausible reason for his success outside of Egypt. However, Sinuhe also claims to possess knowledge that he could not have known at the time. He tells the ruler of Upper Retinu that Sesostris reigns in his father's stead. ${ }^{562}$ This ex post facto knowledge becomes a part of the story as Sinuhe attempts to gain the favor of Sesostris.

Sinuhe also invoked the appeals that kings and other ranking individuals often used to defend themselves against their critics in autobiographical notes written on tombs. He cites his merits to Sesostris, stating, "I gave water to the thirsty; I showed the way to him who had strayed; I rescued him who had been robbed. When Asiatics conspired to attack the Rulers of the Hill-Countries, I opposed their movements." These statements show Sinuhe's nobility and emphasize his loyalty.

Similar to Huattušili, Sinuhe's manipulation of the reader shines forth in his continual appeal to the divine. When Sinuhe participates in a battle of champions, he wins and reasons that "it was the god who acted, so as to show mercy to one with whom he had been angry, whom he had made stray abroad. For today his heart is appeased." ${ }^{\circ 64}$ Sinuhe's victory proves his innocence: if Sinuhe were guilty of treachery, the god would have allowed him to die. Just as the god relented in his treatment of Sinuhe, the

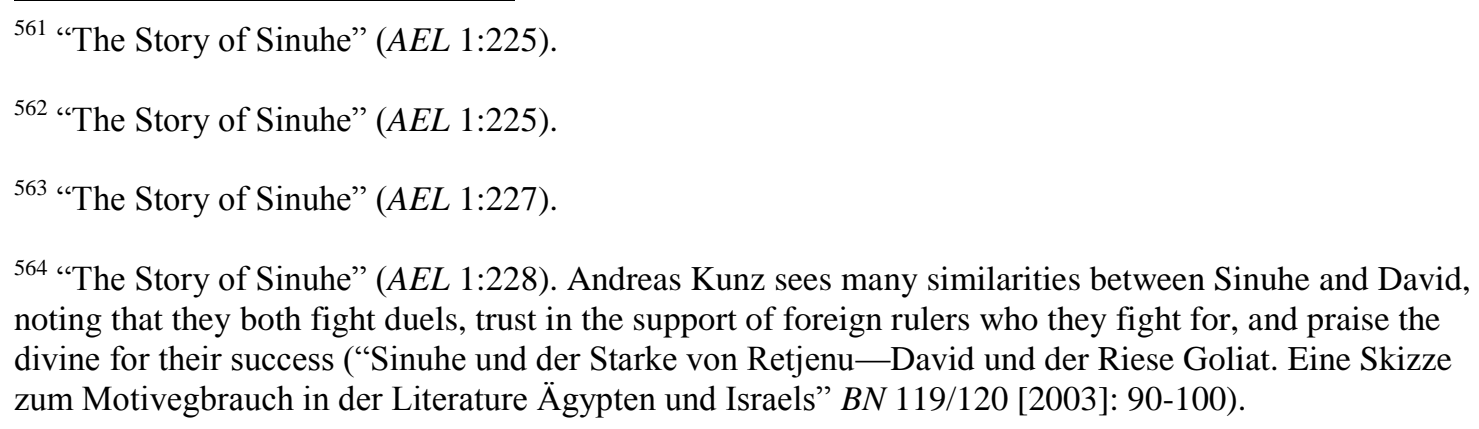
noting that they both fight duels, trust in the support of foreign rulers who they fight for, and praise the divine for their success ("Sinuhe und der Starke von Retjenu-David und der Riese Goliat. Eine Skizze zum Motivegbrauch in der Literature Ägypten und Israels” BN 119/120 [2003]: 90-100). 
protagonist hopes that Sesostris will do the same. To further show his loyalty to Egypt, Sinuhe says that during his time away, "My thoughts are at the palace!"565

Sinuhe made all of these arguments to Sesostris because his fear of dying outside of Egypt trumped his fear of being accused of treachery. Sesostris responded favorably to Sinuhe, taking care of him for the remainder of his life and providing for the afterlife as well. Even though potentially unreliable and filled with half-truths, Sinuhe's words save him in the end. ${ }^{566}$

\section{The Shipwrecked Sailor}

Another Middle Kingdom text, the Tale of the Shipwrecked Sailor also focuses on the power of words and contains an example of a break in pattern. The entertaining narrative shows the importance of the autobiographical style in Egyptian literature since both the Sailor and the Serpent swap tales of calamity in this story within a story within a story. ${ }^{567}$ In addressing a Count who fears that he will not find favor with the king after an expedition, the Shipwrecked Sailor tells his own story of nautical misfortune and also shares the tale of woe from a serpent he met on a mystical island. This tale of wonder provided entertainment for readers. Parts of the story may come from actual sailors who recounted their expeditions since the narrative describes sailors as having "hearts stouter

\footnotetext{
565 "The Story of Sinuhe" (AEL 1:228).

${ }^{566}$ For connections between Sinuhe and other stories of exile and return, see J. Robin King, "The Joseph Story and Divine Politics: A Comparative Study of a Biographical Formula from the Ancient Near East," JBL 106 (1987): 577-94.

${ }^{567}$ See Olivier Perdu, “Ancient Egyptian Autobiographies," in CANE IV: 2243-54.
} 
than lions" and speaks of their prowess at predicting storms. ${ }^{568}$ At the very least, these references lend an air of authenticity to the story.

Readers can only wonder what sailors may have seen on their journeys. Later reports of mermaids and the hallucinations of Coleridge's Ancient Mariner set the stories of sailors in the realm of fantasy. ${ }^{569}$ Scribes may have added hints of religious piety and didactic wisdom to The Shipwrecked Sailor. Perhaps the tale originated in an oral tradition since it makes such an effort to impress the value of proper speech on readers.

The importance of proper speech and the influence of biography shine forth in the framing of the story. "Listen" is a key word in the story's frame. The Sailor states, "It is good for people to listen. ${ }^{, 570}$ Both the Sailor and the Snake frame their stories by noting that they will tell something that happened to them. ${ }^{571}$ Between their stories, the Snake tells the Sailor: "How happy is he who tells what he has tasted, when the calamity has passed." ${ }^{572}$ Unfortunately for the Count, the calamity may not pass because he neither speaks nor listens well. Nevertheless the Sailor attempts to advise him.

Perhaps the Count should have felt optimistic since the Sailor speaks of the voyage's success. If the king acts unfavorably toward him, the Count may attribute the very fact of his survival as evidence of his innocence in any perceived transgression-a strategy Sinuhe utilized effectively. The Count, however, may have reason to fear the

\footnotetext{
568 "The Shipwrecked Sailor" (AEL 1:213).

${ }^{569}$ See Susan Tower Hollis, "Tales of Magic and Wonder from Ancient Egypt,” in CANE IV: 2255-64.

570 "The Shipwrecked Sailor" (AEL 1: 215).

571 “The Shipwrecked Sailor” (AEL 1:212-13).

572 "The Shipwrecked Sailor" (AEL 1:213).
} 
king. Something bad may have happened on the voyage, and readers may wonder about this potential gap. Problems on expeditions were not unknown. For example, the New Kingdom account of the Report of Wemanum tells of an expedition fraught with difficulties. ${ }^{573}$

Perhaps the Count's real problem is his inability to converse well and his lack of wisdom. The scribe mentioned in the colophon certainly values the skill of speaking and writing well. Ameny son of Amenyaa speaks of writing with "clever fingers." the ancients championed the scribal arts as one of the greatest professions. In "The Satire of the Trades," a father is taking his son to a scribal school. ${ }^{575}$ Along the way, he criticizes other professions while continually extolling the role of the scribe.

Perhaps the scribe used the Tale of the Shipwrecked Sailor to disparage the Count's profession. ${ }^{576}$ The Count has no time for stories. In the end, he simply quotes what might be construed as a riddle or a proverb, "Who pours water [for] a goose, when the day dawns for its slaughter on the morrow?"577 Therefore the Count gives the appearance of having wisdom, but his actions do not bear it out.

\footnotetext{
573 "The Report of Wenamun” (AEL 2:224-32).

574 “The Shipwrecked Sailor” (AEL 1:215).

575 "The Satire of the Trades" (AEL 1:184-192).

${ }^{576}$ The fact that the Sailor disdains the Count's profession and praises sailors may be related to the fact that, according to Parkinson, "by the start of the Middle Kingdom there was a "middle class' in a more flexible and differentiated society than is usually assumed" ("Individual and "Society," 137-38). Furthermore, Parkinson states, "The multiple levels of meaning in tales such as the Shipwrecked Sailor and Sinuhe, which are both adventure tales and symbolic narratives, might suggest that they were intended for audiences of varying levels of sophistication" (142).

577 “The Shipwrecked Sailor” (AEL 1:215).
} 
The influence of wisdom literature is revealed when the Sailor discusses the value of proper speech: "Wash yourself! Pour water on your hands! So you may reply when you are addressed, and speak to the king with self-possession, and answer without stammering. A man's utterance saves him. His speech turns anger away from him" (1419). The latter part of the speech is similar to Proverbs 18:21, "Death and life are in the power of the tongue; And those who love it will eat its fruit (NRSV)"

The Sailor clung to life and used the power of the tongue to overcome his circumstances. The text uses poetic and dramatic language as the Sailor relates his plight. In writing of his calamity at sea, he says, "Then the ship died." $" 578$ The Sailor describes his isolation after the shipwreck: "I spent three days alone with my heart as my companion. ${ }^{, 579}$ As the sole survivor, he came ashore on a mythical island where he met a Snake who symbolized an Egyptian deity. He gives readers access to his inner thoughts when he hears the Snake approaching, "Then I heard a thundering noise and thought, 'It is a wave of the sea." $" 580$

When the Snake appears, readers see a role reversal in lines 68-69. The Snake is "raised upwards" while the Sailor "was prostrate in front of him." 581 The Sailor shows the appropriate reverence, and the Snake rewards his piety. The Snake makes up for the Sailor's losses, and the Sailor returns home successfully. Perhaps the story illustrates that the Sailor's ability to successfully speak with this deity brought him favor with his

\footnotetext{
578 "The Shipwrecked Sailor" (AEL 1:212). Similarly, Jonah 1:4 attributes human attributes to the ship, noting that the ship "thought" to break up.

579 "The Shipwrecked Sailor" (AEL 1:212).

580 “The Shipwrecked Sailor” (AEL 1:212).

581 “The Shipwrecked Sailor” (AEL 1:212).
} 
master, showing that those who appease the divine will appease earthly rulers like the divine Pharaoh. The Count may lack oratory skills because he never took the time to petition the gods. The Sailor has both abilities, and the Snake charges him to "Make me a good name in your town; that is what I ask of you.",582

An break in the pattern of the text may reinforce the Count's lack of rhetorical skills because it further lowers the Count's status while elevating the position of the reader. In telling his tale to the Count, the Sailor describes his shipmates, noting their strength and ability to predict a storm. When the Sailor relates the same story to the Snake, he supplements this description by saying, "There was not a fool among them." The Sailor's words are a jab at the Count, and they reveal his lack of wisdom as the real source of his problem. Proverbs 18:6-7 state, “A fool's lips bring strife. His mouth invites a beating. The mouth of the fool is his destruction; His lips are a snare to him." The king possesses the power of life and death, and the Count fears that he may not have the king's favor. Since the story offers readers no additional reasons for the king's potential anger and the Sailor speaks of a successful journey, the Count may create a problem where none exists. The tale criticizes the oratorical ignorance of the Count, showing that he lacks the rhetorical skills to avoid the wrath of the king - even upon the completion of a prosperous journey.

\footnotetext{
582 “The Shipwrecked Sailor” (AEL 1:214).

583 “The Shipwrecked Sailor" (AEL 1:213). Although Gary A. Rendsburg notices the addition of the phrase in the repetition, he never mentions its function in the text. ("Literary Devices in the Story of the Shipwrecked Sailor,” JAOS 120 [Jan.-Mar. 2000]: 13-23).
} 


\section{Conclusion}

A search for the voice of the narrator in ANE literature reveals a wide range of possibilities. Since Hurro-Hittite scribes rely on their ability to effectively communicate a story to a reader, they utilize neutral omniscience, the most basic type of omniscience. They assume that their audience will accept their communication of a narrative without question and, therefore, have no cause to obtrude. Ugaritic narrators also have little need for obtrusions since they envision a scholarly audience that will readily understand their work; as a result, they leave gaps in the texts, counting on these erudite readers to fill them. Although the narrator's voice is generally absent from Ugaritic narrative poetry, the narrator's voice occasionally merges with the voice of a character in indirect free speech. Like the gaps employed by Ugaritic narrators, such artistry is subtle. Although the narrators in Ugaritic and Hurro-Hittite literature display very basic omniscience and no evidence of obtrusiveness, perhaps their voices would have gained more force had they received the opportunity to explain or protest their respective fates.

Kabti-ilāni-Marduk and the Deuteronomistic School had this opportunity, and they responded with innovative and artistic approaches. The Deuteronomistic School used God as a character in their stories and related the thoughts and words of God. Kabtiilāni-Marduk went one step further by merging his voice with that of a god in order to praise himself. Both also made use of obtrusions. The third person biblical narrators relied on the divine to solve problems much like the first person Egyptian narrators Sinuhe and the Shipwrecked Sailor, who invoked the gods to proclaim their innocence. Rather than protecting the gods or merely invoking them, Kabti-ilāni-marduk openly challenged the divine. In spite of Kabti-ilāni-marduk's aspirations to be God-like, he and 
other ANE narrators still possessed the type of restricted knowledge the so called omniscient gods possessed. While their artistry is great, their omniscience is not all encompassing like the God of Jewish and Christian tradition. 


\section{CHAPTER VI}

\section{CONCLUSION}

By examining obtrusions directly communicated through the voice of the narrator, I have highlighted an anomalous action of the laconic narrator of the Hebrew Bible. The narrator not only inserts explanatory glosses and explicit commentary into the text, but massive intrusions occur as well. Although these obtrusions stop short of directly addressing the reader as in an apostrophe, they are a sharper manifestation of omniscience.

Obtrusions occur because the narrator preemptively responds to a question or assumption that may arise from a knowledgeable reader. Because this type of reader may have the tendency to be creative or theologically presumptuous, the narrator seeks to remove agency from the reader by foreclosing questions. The narrator may also affect the agency of a character by using the divine to explain situations. Although other explanations may appear in a narrative, the narrator wants the reader to understand that everything falls under the control of the divine. In spite of the fact that some obtrusions remove agency from readers and characters, the narrator also creates obtrusions that rely on reader knowledge; or the narrator may employ an obtrusion to protect a character.

\section{Deleting an Obtrusion}

Determining the impact of deleting a comment is the most essential part of my methodology for examining obtrusions due to their effect on the agency of readers as well 
as characters. Refraining from obtruding might leave open a gap that the narrator finds unacceptable. Therefore biblical narrators often seek to lessen theological tension by filling in a gap with an obtrusion. Ironically, obtrusions may inadvertently create more problems for the questioning reader. Some readers, however, will readily accept the narrator's point of view, especially if the narrator's comment introduces the theme of divine control.

Deleting obtrusions that deal with divine control can affect the agency of characters. For example, omitting Judg 14:4 would cause readers to base Samson's decision to marry the Timnite on characterization rather than divine intervention. Without the obtrusion, Samson's agency is not in question. Likewise, removing the evil spirit from the story of Abimelech might lead readers to believe that the hostilities between Abimelech and the Shechemites arose due to their own wicked natures rather from God. These obtrusions from the Deuteronomistic History are similar to the hardening of Pharaoh's heart in the book of Exodus. ${ }^{584}$ God removes agency from Pharaoh in order to show divine might. In all of these cases, the narrator wants the reader to know that God is in control.

Although the narrator characterizes Samson as a morally suspect individual and Abimelech, the Shechemites, and Pharaoh are negatively portrayed, the narrator also invokes the divine to exercise control over favored characters. In 1 Sam 26:12, God sends

\footnotetext{
${ }^{584}$ Exodus speaks of the hardening of the Pharaoh's heart, but does not always directly attribute it to God (7:14; 8:15, 32; 9:7, 34-35). Several verses describe the hardening of Pharaoh's heart as confirmation of the words of God $(7: 22 ; 8: 19)$. In other verses, the narrator specifically states that God hardened Pharaoh's heart $(9: 12 ; 10: 20,27 ; 11: 10 ; 14: 8)$. In 10:1, God states that God hardened Pharaoh's heart. Similarly, Deut 2:30 speaks of God hardening Sihon's spirit. However, in 1 Sam 6:6, the priests and diviners of the Philistines state that Pharaoh and the Egyptians hardened their own hearts.
} 
a deep sleep on Saul and his men when David and Abishai sneak into Saul's camp. Without this comment, readers might assume that David's stealth or Abner's negligence created the opportunity for David to murder Saul.

Divine causality in obtrusions supersedes the characterization of figures in the biblical narrative - no matter how the rest of the text portrays them. In order to confront a reader's assumption about a character, the narrator may insert the divine into the text. Berlin makes note of $1 \mathrm{Kgs}$ 12:15 in which the Lord prevented Rehoboam from listening to the people. Readers relying on the characterization of the king and the narrator's omniscient remark in $1 \mathrm{Kgs}$ 12:8 might assume that the king merely preferred the advice of his courtiers to the counsel of the elders. The narrator, however, wants the reader to know that God orchestrated these events. In many cases, the narrators employ obtrusions in order to grant ultimate agency to God.

\section{Reader Knowledge}

Other obtrusions arise because the narrator may assume that knowledgeable readers will make connections between stories and traditions or because the narrator would like the reader to make such a connection. In Josh 15:63, the narrator envisions a knowledgeable reader who will wonder why Jerusalem does not appear among the lists of Judah's cities. The narrator reminds the reader of the Jebusite occupation of Jerusalem during the period of the Conquest, but offers no further explanation, perhaps relying on the reader to connect David with the future capture of the city. Similarly, Josh 11:22 mentions that the Anakim still remain in the Philistines cities of Gaza, Gath, and Ashdod. The narrator obtrudes because knowledgeable readers may connect the giant Goliath with 
Gath. Additionally, the narrator of $1 \mathrm{Kgs}$ 22:28b may envision a reader who will connect the story of the prophet Micaiah with the prophet Micah. The narrator confirms this connection or places it in the mind of the reader by using a phrase traditionally associated with Micah.

\section{Protecting Characters}

The narrator also uses obtrusions to protect characters. In Gen 34:13-14, the narrator obtrudes to let readers know that the sons of Jacob had a pretext for asking the Shechemites to circumcise their males. The Shechemites were also acting deceitfully, hoping to acquire the Israelites' possessions through marriage. This obtrusion balances the Shechemite pretext with the Israelite pretext. Without the obtrusion, the unexpected savagery and violence of Simeon and Levi would have shocked readers. By intervening, the narrator forecloses unpleasant questions that the readers might ask about these characters.

The book of Joshua strives to protect the character of Joshua by placing the theme of divine control around the treaty he made with the Gibeonites. In Josh 11:19-20, the narrator describes this agreement as an exceptional occurrence. In verse 20, the narrator explains that no other groups sought similar alliances because the Lord hardened their hearts. The questioning reader, however, may wonder why the Lord did not also harden the hearts of the Gibeonites. ${ }^{585}$ Additionally, readers may remember that Joshua failed to consult the Lord before making the treaty. By stating that the Lord hardened the hearts of

\footnotetext{
${ }^{585}$ Both the narrator of Exodus and the narrator of Joshua utilize the explanation of the hardening of the heart, but they do so in different ways. The Exodus narrator uses it to govern all of Pharaoh's actions, and the reason frames the narrative of the plagues. In contrast, the narrator of Joshua inserts this exception into the story to deal with a troubling issue about a favored character.
} 
all the nations except the Gibeonites, the narrator protects Joshua because he is a favored character who is constantly portrayed as the new Moses.

A particularly sharp obtrusion occurs in Josh 10:14 when the narrator attempts to protect God and exalt Joshua. The narrator claims that Joshua commanded God to make the sun and the moon stand still. While commentators credibly argue that the narrator employed such language to protect Yahweh from competing deities like the sun and the moon, the narrator's language also greatly magnifies Joshua. In spite of the fact that Joshua fights this battle due to the foolish treaty he made with the Gibeonites, the story sets the stage for Joshua to become as great as Moses. God may have spoken to Moses, but Joshua commands God in this narrative. Perhaps the desire to protect Yahweh and to exalt Joshua led to an obtrusion far more excessive than most.

\section{The Desire for Sharper Obtrusions}

In other cases, later interpreters of a text express discomfort with a story and behave more obtrusively than the biblical narrator. In Gen 22:1, the narrator may fear that readers will associate Yahweh with child sacrifice. To prevent any hint of this notion from rising to the surface, the narrator intervenes at the beginning of the Aqedah, describing all of the events that follow as a test for Abraham. The force of this obtrusion resonated throughout later interpretations, with ancient commentators retroactively deeming earlier events in the life of Abraham as tests. In spite of the narrator's intervention, ancient and modern commentators continued to question divine motive in the Aqedah, revealing that the narrator of Gen 22:1 could have acted even more 
obtrusively. Ancient readers obtruded by adding otherworldly beings like ha-Satan or the Prince of Animosity to the story.

The biblical text offers a nice example of how different narrative schools address a theological problem with an obtrusion. 2 Sam 24:1 states that God incited David to number the people while 1 Chron 21:1 makes ha-Satan the culprit. Perhaps a different theological worldview led the Chronicler to replace God with ha-Satan in the text. Perhaps the Deuteronomist chose not to obtrude in this manner because the school makes God the ultimate cause behind events. Even in Deuteronomistic narratives with evil spirits, such as Abimelech and Micaiah, God employs these otherworldly beings to do God's bidding. Questions about the nature of God and evil in these passages and in the Aqedah continue to trouble readers.

Modern readers have viewed the testing explanation in the Aqedah as inadequate to answer their ethical questions. Perhaps such a question could never be foreclosed sufficiently, but the fact that the narrator obtruded attests to the narrator's foresight into potential reader questions.

Such questions intruded into the framework created by the narrator. In some instances, the narrator broke the frame of the text to offer explanations. In other cases, the narrator strategically placed commentary outside of the narrative framework in non-break frame obtrusions. Most obtrusions either invoked the divine to explain a situation or protected the divine or some other character. Although historical asides by the narrator break the time frame of a narrative, they rarely reveal attempts by the narrator to actively shape reader response. 


\section{Confronting Questions}

Some obtrusions, however, work to create harmony in the larger historical picture of a narrative. Judg 2:22 strives to harmonize Joshua and Judges by defining the nations that remained after the Conquest as a test for Israel. The narrator confronted the unwieldy question about the continued presence of these nations after Joshua's military campaigns, attempting to create coherence in a history filled with contradictions.

Unsatisfied with the answer provided in Judg 2:22, the narrator of Judg 3:2 intervened, explaining that the nations remained so that future generations of Israelites could learn how to fight in wars. The narrator forcefully obtrudes in this verse by describing this reason as the "only" explanation for why God allowed the other nations to remain. Judg 2:22 and 3:2 show the narrators' wrestlings with difficult questions and perhaps show that they wanted to prevent readers from engaging in such struggles.

Such questions reveal that the narrators are the initial readers of the text they are composing or redacting. As the first readers to confront perplexing questions, they deserve a place in the study of reader response. Obtrusions may reveal the psychology of the narrators: perhaps these interruptions represents the narrator's insecurities and lead them to prevent the reader from experiencing the same difficulties. The narrators may envision questions and assumptions from readers because they had similar responses to the text. As a result, they crafted answers in obtrusions in order to foreclose these issues. Possessing a worldview of God's ultimate agency, narrators like the Deuteronomist often inserted the divine into a text to bring coherence to their work. This introduction of the divine, however, may have raised new questions for readers who would not cede interpretive control to the narrator. 


\section{Looking Forward}

By discussing narrative obtrusions, this project has opened doors for further exploration of the various manifestations of the narrator's voice. In particular, the merging of the narrator's voice with the voice of a character demands more attention. Although this study briefly examined the emergence of indirect free speech in Ugaritic narrative, research on this phenomenon in ANE literature and in the Hebrew Bible warrant additional discussion. For example, in passages like Josh 4:23-24, translators and commentators have difficulty identifying Joshua or the narrator as the speaker. These verses raise the question of whether the narrator employs indirect free speech or merges voices with Joshua in order to claim greater authority, much like Kabti-ilāni-Marduk joins his voice with the voice of the divine.

Other obtrusive possibilities where the narrator commandeers the voice of a character deserve more attention. Instances where characters invoke the divine or seek to protect themselves, the divine, or other characters may reveal obtrusiveness. Such an inquiry could further define the nature of the narrator. Perhaps the narrator appears laconic and only occasionally obtrudes in the narrator's own voice because the voices of characters provide easier and better vehicles for communicating the narrator's objectives.

Other narrative voices in the biblical text warrant consideration. While this study has focused on the Deuteronomistic History because of its frameworks, research on other books of the Hebrew Bible may be productive. The book of Genesis may be a promising narrative to search for the narrator's voice and consider the omniscient and obtrusive possibilities. God's appearance as a character in many of the book's stories offers more possibilities for discussing the way the biblical narrator handles the divine. The way in 
which a seemingly omniscient narrator portrays a seemingly omniscient character creates many questions worthy of discussion. In particular, the Joseph story may prove useful for future work since it focuses on the theme of divine control. Further study is also need in ANE literature since this presentation has only begun to explore this vast literature.

Reception history also represents a potentially fruitful area of inquiry since it has offered valuable reader responses to the obtrusions in this study. The present endeavor has considered responses from ancient commentators as well as modern day scholars. Future work, however, may focus on a specific tradition of reception history, such as in the Targums or in rabbinic writings. In particular, the commentary of the rabbis may offer significant areas for comparison since the rabbis continuously look to plug gaps in the biblical text, raise various questions, and provide multiple answers to these queries. The laconic nature of the biblical narrator may have shaped rabbinic analysis. An obtrusive narrator who offered more definitive commentary might have inhibited the scope of some rabbinic explanations. Contrasting the narrator's obtrusions and gaps with the rabbis' explanations could lead to enriching discourse.

\section{Final Thoughts}

In recasting the generally laconic narrator as occasionally obtrusive, this study has attempted to redefine some of the possibilities for narrative criticism by utilizing redaction criticism and reader response and by considering the ANE context of biblical literature. Bringing the control of the narrator back into the conversation between the text and the reader fills in a gap that currently exists in biblical studies. With historical 
criticism and reader oriented approaches dominating many of the discussions about the Hebrew Bible, this study of narrative obtrusiveness allows the voice of the narrator to be represented in the midst of many other voices and opinions that deserve to be heard. Some of the questions raised by these voices may benefit from examining the way the obtrusive narrator wrestled with difficult issues. 


\section{APPENDIX A: SELECTED OBTRUSIONS FROM THE HEBREW BIBLE ${ }^{586}$}

\begin{tabular}{|c|c|c|}
\hline Reference & Verse & Analysis \\
\hline $\begin{array}{l}\text { Gen } \\
22: 1\end{array}$ & $\begin{array}{l}\text { "And it happened after } \\
\text { these things that God } \\
\text { tested Abraham..." }\end{array}$ & $\begin{array}{l}\text { Perhaps anticipating unwelcome questions about the divine, } \\
\text { the narrator intrudes at the beginning of the story to block } \\
\text { them. Although the comment is essential, the narrator could } \\
\text { have placed it later in the story; but perhaps the narrator } \\
\text { wanted to prevent even the inkling of any questions from } \\
\text { arising. Later interpreters behaved more obtrusively by } \\
\text { adding other worldly characters such as ha-Satan to the } \\
\text { story in order to remove culpability from God. }\end{array}$ \\
\hline $\begin{array}{c}\text { Gen } \\
34: 13-14\end{array}$ & $\begin{array}{l}13 \text { "Jacob's sons answered } \\
\text { Shechem and his father } \\
\text { Hamor -- speaking with } \\
\text { guile because he had } \\
\text { defiled their sister Dinah -- } \\
14 \text { and said to them, "We } \\
\text { cannot do this thing, to give } \\
\text { our sister to a man who is } \\
\text { uncircumcised, for that is a } \\
\text { disgrace among us"' (TNK). }\end{array}$ & $\begin{array}{l}\text { The narrator must obtrude to balance the Israelites' pretext } \\
\text { with the Shechemites' pretext. The Shechemites are } \\
\text { plotting to take Israel's possessions by marrying their } \\
\text { daughters. The narrator informs the reader of the Israelite } \\
\text { plot to weaken the Shechemites through circumcision. If the } \\
\text { narrator had not informed the reader about the plans of the } \\
\text { sons of Jacob, the reader would have a number of questions } \\
\text { about the story because of the surprising deceit and } \\
\text { savagery of the Israelites. By obtruding in the text, the } \\
\text { narrator forecloses these possibilities. }\end{array}$ \\
\hline $\begin{array}{c}\text { Ex 9:12 } \\
\text { (cf. Ex } \\
10: 20,27 \\
11: 10 ; 14: 8) .\end{array}$ & $\begin{array}{l}\text { "But the LORD hardened the } \\
\text { heart of Pharaoh, and he } \\
\text { would not listen to them, } \\
\text { just as the LORD had spoken } \\
\text { to Moses" (NRSV). }\end{array}$ & $\begin{array}{l}\text { In order to show the power of God, God hardens Pharaoh's } \\
\text { heart. The explanation governs the storyline and deals with } \\
\text { readers who might wonder why Pharaoh would continue to } \\
\text { be obstinate in the face of the plagues. (See also } 1 \text { Sam 6:6 } \\
\text { where the Philistines state that Pharaoh and the Egyptians } \\
\text { hardened their hearts. The Philistines never mention God as } \\
\text { the cause of the Egyptians' unwillingness to let the } \\
\text { Israelites leave). }\end{array}$ \\
\hline Deut 2:30 & $\begin{array}{l}\text { But King Sihon of Heshbon } \\
\text { was not willing to let us pass } \\
\text { through, for the LoRD your } \\
\text { God had hardened his } \\
\text { spirit and made his heart } \\
\text { defiant in order to hand } \\
\text { him over to you, as he has } \\
\text { now done (NRSV). }\end{array}$ & $\begin{array}{l}\text { Without this obtrusion, readers might assume that Heshbon } \\
\text { acted wickedly or perhaps had good reason to prevent Israel } \\
\text { from going through his territory. The narrator explains that } \\
\text { God hardened his heart just as God hardened the heart of } \\
\text { Pharaoh. }\end{array}$ \\
\hline $\begin{array}{l}\text { Josh } \\
10: 14\end{array}$ & $\begin{array}{l}\text { "for the Lord fought for } \\
\text { Israel. Neither before nor } \\
\text { since has there ever been } \\
\text { such a day, when the Lord } \\
\text { acted [obeyed] on words } \\
\text { spoken by a man" (TNK). }\end{array}$ & $\begin{array}{l}\text { The narrator obtrudes to protect God from being } \\
\text { overshadowed by the sun and the moon since some readers } \\
\text { might have viewed them as deities. In doing so, the narrator } \\
\text { raises Joshua to an extraordinary position. The Lord obeys } \\
\text { the words of Joshua. This obtrusion far exceeds those } \\
\text { instances where God responds to an individual's prayers. }\end{array}$ \\
\hline
\end{tabular}

${ }^{586}$ All obtrusions are in bold. 


\begin{tabular}{|c|c|c|}
\hline $\begin{array}{c}\text { Josh } \\
11: 19-20\end{array}$ & $\begin{array}{l}\text { Apart from the Hivites } \\
\text { who dwelt in Gibeon, not a } \\
\text { single city made terms with } \\
\text { the Israelites; all were taken } \\
\text { in battle. }{ }^{20} \text { For it was the } \\
\text { LORD's doing to stiffen } \\
\text { their hearts to give battle } \\
\text { to Israel, in order that they } \\
\text { might be proscribed } \\
\text { without quarter and wiped } \\
\text { out, as the LORD had } \\
\text { commanded Moses" } \\
\text { (TNK). }\end{array}$ & $\begin{array}{l}\text { The Gibeonite exception creates problems for the narrator, } \\
\text { and the narrator must explain why other nations did not } \\
\text { seek a treaty with the Israelites. The narrator invokes the } \\
\text { Lord to foreclose this question. However, more questions } \\
\text { may arise. The reader may wonder why God did not harden } \\
\text { the hearts of the Gibeonites. }\end{array}$ \\
\hline $\begin{array}{c}\text { Josh } \\
11: 22\end{array}$ & $\begin{array}{l}\text { "None of the Anakim was } \\
\text { left in the land of Israel-- } \\
\text { only in Gaza, Gath, and } \\
\text { Ashdod some remained." }\end{array}$ & $\begin{array}{l}\text { The narrator intervenes to answer the question of a } \\
\text { knowledgeable reader. This type of reader would have } \\
\text { recognized the Anakim as giants and would have wondered } \\
\text { why Goliath of Gath was still around for David to kill. }\end{array}$ \\
\hline $\begin{array}{c}\text { Josh } \\
15: 63\end{array}$ & $\begin{array}{l}\text { "As for the Jebusites who } \\
\text { were living in Jerusalem, } \\
\text { the people of Judah were } \\
\text { not able to drive them out; } \\
\text { and that is why the } \\
\text { Jebusites live with the } \\
\text { people of Judah in } \\
\text { Jerusalem unto this day." }\end{array}$ & $\begin{array}{l}\text { The narrator adds this non-break frame obtrusion to deal } \\
\text { with the question of a knowledgeable reader. Without the } \\
\text { obtrusion, such a reader would wonder why Jerusalem is } \\
\text { not part of the Judah's city list. This obtrusion may create a } \\
\text { gap since it leaves Judah's most important city } \\
\text { unconquered. The narrator, however, may rely on the astute } \\
\text { reader to realize that David will conquer the city. }\end{array}$ \\
\hline $\begin{array}{c}\text { Judg } \\
2: 22-23\end{array}$ & $\begin{array}{l}\text { "For it was in order to } \\
\text { test Israel by them -- to see } \\
\text { whether or not they would } \\
\text { faithfully walk in the ways } \\
\text { of the LORD, as their } \\
\text { fathers had done -- } 23 \text { that } \\
\text { the LORD had left those } \\
\text { nations, instead of driving } \\
\text { them out at once, and had } \\
\text { not delivered them into the } \\
\text { hands of Joshua" (TNK). }\end{array}$ & $\begin{array}{l}\text { In the book of Judges, the narrator must explain the } \\
\text { presence of the other nations while protecting the character } \\
\text { of Joshua since the book of Joshua credits him with driving } \\
\text { out the other nations. The narrator obtrudes to head off } \\
\text { reader questions about these nations, invoking the Lord to } \\
\text { explain the situation. }\end{array}$ \\
\hline $\begin{array}{c}\text { Judg } \\
3: 2\end{array}$ & $\begin{array}{l}\text { "it was only that successive } \\
\text { generations of Israelites } \\
\text { might know war, to teach } \\
\text { those who had no } \\
\text { experience of it before" } \\
\text { (NRSV). }\end{array}$ & $\begin{array}{l}\text { In explaining why the other nations are left in the land, the } \\
\text { narrator protects the character of Joshua since the Israelites } \\
\text { associate him with the conquest of the land. Although } \\
\text { Judges offers several explanations for the continued } \\
\text { presence of the other nations, the narrator of } 3: 2 \text { behaves } \\
\text { obtrusively in order to let the reader know that this reason } \\
\text { supersedes the others since it is the "only" (רק) explanation. }\end{array}$ \\
\hline
\end{tabular}




\begin{tabular}{|c|c|c|}
\hline $\begin{array}{c}\text { Judg } \\
9: 23-24\end{array}$ & $\begin{array}{l}23 \text { "Then God sent an evil } \\
\text { spirit between Abimelech } \\
\text { and the Shechemites, and } \\
\text { the Shechemites dealt } \\
\text { treacherously with } \\
\text { Abimelech. } \\
{ }^{24} \text { That the violence to the } \\
\text { seventy sons of Jerubbaal } \\
\text { might come and their } \\
\text { blood be laid upon } \\
\text { Abimelech their brother } \\
\text { who killed them and upon } \\
\text { the Shechemites who acted } \\
\text { as accomplices in } \\
\text { murdering his brothers." }\end{array}$ & $\begin{array}{l}\text { Otherworldly figures such as God and evil spirits are often } \\
\text { obtrusive forces in narrative. The narrator inserts this non- } \\
\text { break frame obtrusion to ensure readers that God is } \\
\text { responsible for the troubles between Abimelech and the } \\
\text { Shechemites. Without the obtrusion, readers might blame } \\
\text { their contention on their evil natures. The obtrusion places } \\
\text { the entire scenario under the theme of divine control and } \\
\text { retribution. }\end{array}$ \\
\hline $\begin{array}{l}\text { Judg } \\
14: 4 a\end{array}$ & $\begin{array}{l}\text { "But his father and his } \\
\text { mother did not know that } \\
\text { it was of the Lord. He was } \\
\text { seeking an } \\
\text { occasion/pretext against } \\
\text { the Philistines, for at that } \\
\text { time the Philistines were } \\
\text { ruling over Israel." }\end{array}$ & $\begin{array}{l}\text { The reader may wonder why the hero Samson desires an } \\
\text { exogamous marriage when the narrator has created such } \\
\text { high expectations for him. The narrator obtrudes to explain } \\
\text { the situation and also adds an omniscient remark in 14:4b. } \\
\text { Since omitting the obtrusion in 14:4a does not really change } \\
\text { the character of God or Samson, the story could continue } \\
\text { without the obtrusion. The reader would simply assume that } \\
\text { Samson did whatever was right in his own eyes based on } \\
\text { 14:3. Having Samson's actions fall under divine control } \\
\text { creates a number of questions for readers that the history of } \\
\text { interpretation struggles to answer. }\end{array}$ \\
\hline $\begin{array}{c}1 \mathrm{Sam} \\
26: 12 \mathrm{~b}\end{array}$ & $\begin{array}{l}\text { "So David took away the } \\
\text { spear and the water jar at } \\
\text { Saul's head, and they left. } \\
\text { No one saw or knew or } \\
\text { woke up; all remained } \\
\text { asleep; a deep sleep from } \\
\text { the LORD had fallen upon } \\
\text { them" (TNK) }\end{array}$ & $\begin{array}{l}\text { The narrator does not want the reader to assume that } \\
\text { David's stealth or Abner's carelessness allowed David to } \\
\text { sneak into Saul's camp. God is in control of these events, } \\
\text { just as the divine is in control of David's life. Both Saul and } \\
\text { David speak of God being at work in this story, confirming } \\
\text { the words of the narrator. However, when speaking to } \\
\text { Abner, David blames the general for neglecting to protect } \\
\text { Saul. The two interpretations by David reveal that he reads } \\
\text { the story in the way most advantageous to him. }\end{array}$ \\
\hline 2 Sam 3:37 & $\begin{array}{l}\text { "So all the people and all } \\
\text { Israel understood that day } \\
\text { that the king had no part } \\
\text { in the killing of Abner son } \\
\text { of Ner" (NRSV). }\end{array}$ & $\begin{array}{l}\text { Anticipating that readers may suspect David in the death of } \\
\text { Abner, the narrator obtrudes to explain that all of the people } \\
\text { knew that David was not to blame. }\end{array}$ \\
\hline 2 Sam 24:1 & $\begin{array}{l}\text { "Again the anger of the } \\
\text { LORD was kindled against } \\
\text { Israel, and he incited } \\
\text { David against them, } \\
\text { saying, 'Go, count the } \\
\text { people of Israel and } \\
\text { Judah"' (NRSV). }\end{array}$ & $\begin{array}{l}\text { The Deuteronomist claims that God caused David to } \\
\text { number the people in order to punish them. Even in a } \\
\text { mistake by David, the Deuteronomist wants readers to } \\
\text { know that God is behind the king's actions. The story most } \\
\text { likely arose as a way to explain pestilence. (See the } \\
\text { obtrusion the narrator creates using ha-Satan in } 1 \text { Chron } \\
21: 1 \text { ). }\end{array}$ \\
\hline
\end{tabular}




\begin{tabular}{|c|c|c|}
\hline $\begin{array}{c}1 \mathrm{Kgs} \\
12: 15 \mathrm{~b}\end{array}$ & $\begin{array}{l}\text { for the LORD had brought } \\
\text { it about in order to fulfill } \\
\text { the promise that the } \\
\text { LORD had made through } \\
\text { Ahijah the Shilonite to } \\
\text { Jeroboam son of Nebat } \\
\text { (TNK). }\end{array}$ & $\begin{array}{l}\text { The narrator does not want readers to assume that } \\
\text { Rehoboam acted of his own volition. Even though the } \\
\text { narrative has spoken of him listening to his contemporaries } \\
\text { rather than his elders, readers must realize that God is in } \\
\text { control of this decision that will divide the nation of Israel. }\end{array}$ \\
\hline $\begin{array}{c}1 \mathrm{Kgs} \\
22: 28 \mathrm{~b}\end{array}$ & $\begin{array}{l}\text { "To which Micaiah retorted, } \\
\text { 'If you ever come home } \\
\text { safe, the LORD has not } \\
\text { spoken through me.' He } \\
\text { said further, 'Listen, all } \\
\text { you peoples!"' (TNK) }\end{array}$ & $\begin{array}{l}\text { The narrator adds the signature phrase of the prophet Micah } \\
\text { (Mic 1:2) to show readers that Micaiah and Micah are one } \\
\text { and the same. Although historical criticism correctly } \\
\text { disputes this connection, knowledgeable readers may tie the } \\
\text { two together. The narrator emphasizes this point to such } \\
\text { readers while placing the idea in the minds of other readers. }\end{array}$ \\
\hline 1 Chron 21:1 & $\begin{array}{l}\text { "Satan stood up against } \\
\text { Israel, and incited David to } \\
\text { count the people of Israel" } \\
\text { (NRSV). }\end{array}$ & $\begin{array}{l}\text { Rather than blaming God or David for the counting of the } \\
\text { people, the Chronicler attributes the inciting of David to ha- } \\
\text { Satan similar to the way that later interpretations of Gen } \\
\text { 22:1 seek to remove any culpability from God. (See } 2 \text { Sam } \\
\text { 24:1 where the Deuteronomist attributes the inciting of } \\
\text { David to God). }\end{array}$ \\
\hline
\end{tabular}




\section{APPENDIX B: SOME MORE OBTRUSIONS NOT COVERED IN THIS STUDY 587}

\begin{tabular}{|c|c|c|}
\hline Reference & Verse & Analysis \\
\hline Ex 6:26 & $\begin{array}{l}\text { "It is the same Aaron and } \\
\text { Moses to whom the LORD } \\
\text { said, "Bring forth the } \\
\text { Israelites from the land of } \\
\text { Egypt, troop by troop." }\end{array}$ & $\begin{array}{l}\text { The narrator intrudes to deal with any potential questions } \\
\text { about Aaron and Moses, ensuring readers of their identity. }\end{array}$ \\
\hline Ex 13:17 & $\begin{array}{l}\text { "Now when Pharaoh let the } \\
\text { people go, God did not lead } \\
\text { them by way of the land of } \\
\text { the Philistines, although it } \\
\text { was nearer; for God said, } \\
\text { 'The people may have a } \\
\text { change of heart when they } \\
\text { see war, and return to } \\
\text { Egypt." }\end{array}$ & $\begin{array}{l}\text { The narrator addresses a potential reader question by } \\
\text { claiming to know the thoughts of God. In fact, NSRV } \\
\text { translates the verse, "for God thought. .." }\end{array}$ \\
\hline Ex 32:25 & $\begin{array}{l}\text { "Moses saw that the people } \\
\text { were out of control -- since } \\
\text { Aaron had let them get } \\
\text { out of control -- so that } \\
\text { they were a menace to any } \\
\text { who might oppose them." }\end{array}$ & $\begin{array}{l}\text { The narrator emphasizes that the fact that Aaron is to blame } \\
\text { for the people's behavior when explaining Moses' plight in } \\
\text { trying to regain control of them. }\end{array}$ \\
\hline $\begin{array}{l}\text { Num 16:39- } \\
\quad 40\end{array}$ & $\begin{array}{l}39 \text { "So Eleazar the priest } \\
\text { took the bronze censers that } \\
\text { had been presented by those } \\
\text { who were burned; and they } \\
\text { were hammered out as a } \\
\text { covering for the altar -- }{ }^{40} \text { a } \\
\text { reminder to the Israelites } \\
\text { that no outsider, who is } \\
\text { not of the descendants of } \\
\text { Aaron, shall approach to } \\
\text { offer incense before the } \\
\text { LORD, so as not to } \\
\text { become like Korah and } \\
\text { his company -- just as the } \\
\text { LORD had said to him } \\
\text { through Moses." }\end{array}$ & $\begin{array}{l}\text { The narrator interrupts the text to emphasize the role of the } \\
\text { sons of Aaron as the only ones who can offer incense. This } \\
\text { intrusion addresses a larger issue than protecting a character } \\
\text { because it involves protecting the responsibilities of an entire } \\
\text { group. }\end{array}$ \\
\hline
\end{tabular}

${ }^{587}$ Although many more obtrusions exist in the narratives of the Hebrew Bible, this appendix provides a few additional ones for consideration. All obtrusions are in bold. Translations in this appendix are from TNK. 


\begin{tabular}{|c|c|c|}
\hline Deut 7:22 & $\begin{array}{l}22 \text { "The LORD your God } \\
\text { will dislodge those peoples } \\
\text { before you little by little; } \\
\text { you will not be able to put } \\
\text { an end to them at once, } \\
\text { else the wild beasts would } \\
\text { multiply to your hurt." }\end{array}$ & $\begin{array}{l}\text { The Deuteronomist explains why the Israelites could not } \\
\text { achieve a complete conquest before they even enter the land } \\
\text { (cf. Ex 23:29). }\end{array}$ \\
\hline Deut 9:5 & $\begin{array}{l}\text { "It is not because of your } \\
\text { virtues and your rectitude } \\
\text { that you will be able to } \\
\text { possess their country; but } \\
\text { it is because of their } \\
\text { wickedness that the } \\
\text { LORD your God is } \\
\text { dispossessing those } \\
\text { nations before you, and in } \\
\text { order to fulfill the oath } \\
\text { that the LORD made to } \\
\text { your fathers, Abraham, } \\
\text { Isaac, and Jacob." }\end{array}$ & $\begin{array}{l}\text { The Deuteronomist recognizes the presumptions of the } \\
\text { people and responds accordingly. These verses show how } \\
\text { the Deuteronomistic narrator anticipates thoughts and } \\
\text { assumptions. }\end{array}$ \\
\hline 1 Sam 2:25 & $\begin{array}{l}\text { "If a man sins against a } \\
\text { man, the LORD may } \\
\text { pardon him; but if a man } \\
\text { offends against God, who } \\
\text { can obtain pardon for him?' } \\
\text { But they ignored their } \\
\text { father's plea; for the LORD } \\
\text { was resolved that they } \\
\text { should die." }\end{array}$ & $\begin{array}{l}\text { Although Hophni and Phinehas' actions might make them } \\
\text { worthy of death, the narrator foreshadows their deaths, } \\
\text { making God the ultimate cause of their demise instead of the } \\
\text { Philistines. }\end{array}$ \\
\hline 2 Sam 5:12 & $\begin{array}{l}\text { "Thus David knew that } \\
\text { the LORD had established } \\
\text { him as king over Israel } \\
\text { and had exalted his } \\
\text { kingship for the sake of } \\
\text { His people Israel." }\end{array}$ & $\begin{array}{c}\text { The narrator interrupts the text, giving the reader insight into } \\
\text { David's thoughts and explains the significance of building } \\
\text { the palace. The narrator also explains that David became } \\
\text { king for the sake of the people of Israel, giving a higher } \\
\text { purpose to his rule. }\end{array}$ \\
\hline 2 Sam 17:14 & $\begin{array}{l}\text { "Absalom and all Israel } \\
\text { agreed that the advice of } \\
\text { Hushai the Archite was } \\
\text { better than that of } \\
\text { Ahithophel. -- The LORD } \\
\text { had decreed that } \\
\text { Ahithophel's sound advice } \\
\text { be nullified, in order that } \\
\text { the LORD might bring } \\
\text { ruin upon Absalom." }\end{array}$ & $\begin{array}{l}\text { The Lord subverts Ahithophel's counsel in spite of his } \\
\text { reputation ( } 2 \text { Sam 16:23) much like the divine subverts } \\
\text { characterization in other stories. The Lord intervenes to } \\
\text { ensure that David will survive and Absalom will fail. }\end{array}$ \\
\hline
\end{tabular}




\begin{tabular}{|c|c|c|}
\hline $1 \mathrm{Kgs} 3: 2-4$ & $\begin{array}{l}2{ }^{2} \text { "The people, however, } \\
\text { continued to offer sacrifices } \\
\text { at the open shrines, because } \\
\text { up to that time no house } \\
\text { had been built for the } \\
\text { name of the LORD. }{ }^{3} \text { And } \\
\text { Solomon, though he loved } \\
\text { the LORD and followed } \\
\text { the practices of his father } \\
\text { David, also sacrificed and } \\
\text { offered at the shrines. }{ }^{4} \\
\text { The king went to Gibeon } \\
\text { to sacrifice there, for that } \\
\text { was the largest shrine; on } \\
\text { that altar Solomon } \\
\text { presented a thousand } \\
\text { burnt offerings." }\end{array}$ & $\begin{array}{l}\text { The narrator goes to great pains to explain why Solomon } \\
\text { sacrificed at Gibeon. The narrator protects the character. } \\
\text { Although the knowledgeable reader might realize that } \\
\text { Solomon had yet to build the temple, the narrator does not } \\
\text { trust the reader to properly understand why Solomon } \\
\text { sacrificed at Gibeon. }\end{array}$ \\
\hline $\begin{array}{c}\text { Kgs } 21: 25- \\
26\end{array}$ & $\begin{array}{l}25 \text { "Indeed, there never } \\
\text { was anyone like Ahab, } \\
\text { who committed himself to } \\
\text { doing what was } \\
\text { displeasing to the LORD, } \\
\text { at the instigation of his } \\
\text { wife Jezebel. }{ }^{26} \text { He acted } \\
\text { most abominably, } \\
\text { straying after the fetishes } \\
\text { just like the Amorites, } \\
\text { whom the LORD had } \\
\text { dispossessed before the } \\
\text { Israelites.)" }\end{array}$ & $\begin{array}{l}\text { Although the Deuteronomistic narrator often comments on } \\
\text { the reign of various kings, the narrator interrupts the texts } \\
\text { and goes to great lengths to show the evilness of Ahab. This } \\
\text { intrusion is similar to the way that the narrator sometimes } \\
\text { obtrudes to exalt a favored character. }\end{array}$ \\
\hline
\end{tabular}




\section{BIBLIOGRAPHY}

Abramski, Shmuel. “"זידישי מקרא וחקרי קדמוניות. Beth Mikra 7 (1963): 122-27.

Adar, Zvi. The Biblical Narrative. Jerusalem: Department of Education and Culture, World Zionist Organization, 1959. Translation of ha-Sipur ha-Mikrai.

Yerushalayim: ha-Mahlakah le-hinukh ule-tarbut ba-golah shel ha-Histadrut haTsiyonit ha-'Olamit, 1957.

Ahlström, Gösta. "Aspects of the Bible as Literature." (review of The Art of Biblical Narrative by Robert Alter). Journal of Religion 64 (Oct 1984): 520-29.

Aitken, K. T. "Formulaic Patterns for the Passing of Time in Ugaritic Narrative." Ugarit Forschungen 19 (1987): 1-10.

Akimoto, Kazuya. A Multiple Theoretical Approach to Genesis 22: Rebinding the Aqedah. Master's Thesis. Vanderbilt University, 2003.

Alonso Schökel, Luis. "David y la mujer de Tecua: 2 Sm 14 como modelo hermenéutico." Pages 217-30 in Hermenéutica Biblica de la Palabra. Madrid: Ed. Cristiandad, 1987. . A Manual of Hebrew Poetics. Subsidia Biblica 11. Roma: Pontificio Istituto Biblico, 1988.

Alter, Robert. The Art of Biblical Narrative. New York: Basic Books, 1981. . The David Story: A Translation with Commentary of 1 and 2 Samuel. New York; London: W. W. Norton \& Company, 1999.

. Genesis: Translation and Commentary. New York: W.W. Norton, 1996. . The World of Biblical Literature. New York: Basic Books, 1992.

Alter, Robert. ed. Modern Hebrew Literature. Library of Jewish Studies. New York: Behrman, 1975.

Alter, Robert and Frank Kermode, eds. The Literary Guide to the Bible. Cambridge, Mass.: Belknap Press of Harvard University Press, 1987.

Al-Rawi, F. N. H. and J. A. Black. "The Second Tablet of 'Išum and Erra." Iraq 51 (1989): 111-22. 
Amit, Yairah. "The Dual Causality Principle and Its Effects on Biblical Literature." Vetus Testamentum 37 (1987): 385-400.

. History and Ideology: An Introduction to Historiography in the Hebrew Bible. Translated by Yael Lotan. Sheffield, Sheffield Academic, 1999.

Andersson, Greger. Untamable Texts: Literary Studies and Narrative Theory in the Books of Samuel. New York; London: T \& T Clark, 2009.

Arnold, Bill T. $1 \& 2$ Samuel. Edited by Terry Muck, et. al. The NIV Application Commentary. Grand Rapids, Mi.: Zondervan, 2003.

Astour, Michael C. "Semitic Elements in the Kumarbi Myth: An Onomastic Inquiry." Journal of Near Eastern Studies 27 (Jul. 1968): 172-77.

Auerbach, Eric. Mimesis: Dargestellte The Representation of Reality in Western Literature. $50^{\text {th }}$ Anniversary Edition. Princeton, NJ: Princeton University Press, 2003. Reprint of Mimesis. Translated by Willard R. Trask. Princeton, NJ: Princeton University Press, 1953, 1973. Translation of Mimesis; dargestellte Wirklichkeit in der abendländischen Literatur (Berne: A. Francke, 1946).

Auld, A. Graeme. "1 and 2 Samuel." Pages 213-45 in Eerdmans Commentary on the Bible. Edited by J. D. G. Dunn and J. W. Rogerson. Grand Rapids: Eerdmans, 2003. . Joshua, Judges, and Ruth. Daily Study Bible. Edited by John C. L. Gibson. Philadelphia: Westminster, 1984.

Avishur, Yitzhak. Studies in Biblical Narrative: Style, Structure, and the Ancient Near Eastern Literary Background. Tel Aviv-Jaffa: Archaeological Center Publication, 1999.

Bailkey, Nels M. “A Babylonian Philosopher of History.” Osiris 9 (1950): 106-30.

Baines, John. "Interpreting Sinuhe.” The Journal of Egyptian Archaeology 68 (1982): 3144.

Bal, Mieke. Death and Dissymmetry: The Politics of Coherence in the Book of Judges. Chicago Studies in the History of Judaism. Chicago: University of Chicago Press, 1988.

Barthes, Roland. "The Death of the Author." Pages 142-48 in Image, Music, Text. Essays selected and translated by Stephen D. Heath. New York: Hill and Wang, 1977. 
. Image-Music-Text. Translated by Stephen Heath. New York: Hill \& Wang, 1977.

. S/Z. Translated by Richard Miller. London: Jonathan Cape, 1975.

Barton, John Reading the Old Testament: Method in Biblical Study. Revised and enlarged. London: Darton Longmann \& Todd, 1996.

Bar-Efrat, Shimeon. Narrative Art in the Bible. Translated by Dorothea Shefer-Vanson in conjunction with the author. Bible and Literature Series 17. JSOT Supplement Series 70. Sheffield: Almond, 1989.

. "Some Observations on the Analysis of Structure in Biblical Narrative." Vetus Testamentum (1980): 154-73.

Beckman, Gary. "Gilgamesh in Hatti." Pages 37-57 in Hittites Studies in Honor of Harry A. Hoffner Jr. on the Occasion of His $65^{\text {th }}$ Birthday. Edited by Gary Beckman, Richard Beal, and Gregory McMahon. Winona Lake, In.: Eisenbrauns, 2003.

. "Hittite and Hurrian Epic." Pages 255-63 in A Companion to Ancient Epic. Edited by John Miles Foley. Blackwell Companions to the Ancient World. Literature and Culture. Malden, Mass.: Oxford: Blackwell Publishing, 2005.

."The Limits of Credulity." Journal of the American Oriental Society 125 (Jul.Sep. 2005): 343-52.

Begg, Christopher T. "The End of Samson According to Josephus as Compared with the Bible, Pseudo-Philo, and Rabbinic Tradition.” Biblische Notizen 131 (2006): 47 61.

Ben Meir, Samuel. Rabbi Samuel ben Meir's Commentary on Genesis: An Annotated Translation. Translated by Martin I. Lockshin. Jewish Studies 5. Lewiston, NY: E. Mellen, 1989.

Benjamin, Mara H. "The Tacit Agenda of a Literary Approach to the Bible." Prooftexts 27 (2007): 254-74.

Berlin, Adele. Poetics and Interpretation of Biblical Narrative. Bible and Literature Series 9. Sheffield: Almond, 1983. Repr., Winona Lake, Ind.: Eisenbrauns, 1994.

Berman Louis A. The Akedah: The Binding of Isaac. Northwale, NJ.; Jerusalem: Jason Aronson, 1997. 
Bernstein, Sergej. “Ästhetiche Voraussetzungen einer Theorie der Deklamation.” Pages 338-85 in Texte der Russichen Formalisten. 2 volumes. Munich: Wilhelm Fink, 1972.

Black, Jeremy A., et al, eds. The Literature of Ancient Sumer. Oxford: Oxford University Press, 2004.

Blenkinsopp, Joseph. "Some Notes on the Saga of Samson and the Heroic Milieu." Scripture 11 (1959): 81-89.

Bluedorn, Wolfgang. Yahweh Versus Baalism: A Theological Reading of the GideonAbimelech Narrative. Edited by David J. A. Clines and Philip R. Davies. JSOT Supplement Series 329. Sheffield: Sheffield Academic Press, 2001.

Blumenthal, Fred. "Samson and Samuel: Two Styles of Leadership.” Jewish Bible Quarterly 33 (2005): 108-12.

Bodi, Daniel. The Book of Ezekiel and the Poem of Erra. Orbis Biblicus et Orientalis 104. Freiburg, Schweiz: Universitätsverlag; Göttingen Vandenhoeck \& Ruprecht, 1991.

Bodner, Keith. "Is Joab a Reader-Response Critic?" Journal for the Study of the Old Testament 27.1 (2002): 19-35. . "The Locutions of I Kings 22:28: A New Proposal.” Journal of Biblical Literature 122, no. 3 (2003): 533-46.

Boehm, Omri. The Binding of Isaac: A Religious Model of Disobedience. Edited by Claudia V. Camp and Andrew Mein. Library of Hebrew Bible/Old Testament Studies 468. New York; London: T \& T Clark, 2007.

Boling, Robert G. Joshua: A New Translation with Notes and Commentary. The Anchor Bible 6, with an introduction by Ernest G. Wright. Garden City, NY: Doubleday, 1982.

Boling, Robert G., ed. "Symposium: Biblical Narrative in New Perspective.” Biblical Research 31 (1986): 6-25.

Boogart, T. A. "Stone for Stone: Retribution in the Story of Abimelech and Shechem." Journal for the Study of the Old Testament 32 (1985): 45-56.

Bowman, Richard G. "Narrative Criticism: Human Purpose in Conflict with Divine Presence." Pages 17-44 of Judges and Method: New Approaches in Biblical Studies. Edited by Gale A. Yee. Minneapolis: Fortress, 1995. Repr. Minneapolis: Fortress, 2007. 
Brettler, Marc Zvi. The Book of Judges. Old Testament Readings. Edited by Keith Whitelam. New York: Routledge, 2002.

. "The Book of Judges: Literature as Politics." Journal of Biblical Literature 108 (Fall, 1989): 395-418.

Brooke, G. J. and J. D. Kaestli, eds. La narrativité dans la bible et les texts apparentés. Bibliotheca Ephemeridum theologaricum Lovainiensium 149. Leuven-Louvain: Leuven University Press, 2000.

Brown, Francis, and S. R. Driver, and Charles A. Briggs. The Brown-Driver-Briggs Hebrew and English Lexicon. Peabody, Mass.: Hendrickson Publishers, 2000.

Brueggemann, Walter. Genesis: A Bible Commentary for Teaching and Preaching, Interpretation. Atlanta: John Knox, 1982.

. Power, Providence, and Personality: Biblical Insight Into Life and Ministry. Louisville: Westminster/John Knox, 1990.

Buber, Martin. On Judaism. Edited by Nahum N. Glatzer. New York: Schocken, 1967. . “Le Sacrifice d'Isaac.” Dieu Vivant 22 (1952): 69-76.

Burney, C. F. The Book of Judges: With Introduction and Notes. $2^{\text {nd }}$ edition. London: Rivingtons, 1930.

Butler, Trent C. Judges. World Biblical Commentary. Vol. 8. Nashville: Thomas Nelson, 2009.

Campbell, Anthony F. "Form Criticism's Future." Pages 15-31 in The Changing Face of Form Criticism for the Twenty-First Century. Edited by Marvin A. Sweeney and Ehud Ben Zvi. Grand Rapids, Mi.: W. B. Eerdmans, 2003.

. 2 Samuel. Forms of the Old Testament Literature 8. Grand Rapids, Mi.; Cambridge, U.K.: William B. Eerdmans Publishing Company, 2005.

Carasik, Michael. "The Limits of Omniscience." Journal of Biblical Literature 119/2 (2000): 221-32.

Carr, David. Writing on the Tablet of the Heart: Origins of Scripture and Literature. Oxford; New York: Oxford University Press, 2005.

Cartledge, Tony W. 1 \& 2 Samuel. Smith \& Helwys Bible Commentary. Macon, Ga.: Smith \& Helwys, 2001. 
Cassuto, Umberto. A Commentary on the Book of Genesis. 2 vols. Publications of the Perry Foundation for Biblical Research in the Hebrew University of Jerusalem. Jerusalem: Magnes, Hebrew University, 1989. Reprint of A Commentary on the Book of Genesis. Translated by Israel Abrahams. $1^{\text {st }}$ English ed. Magnes, Hebrew University, 1961. Translation of Part 1: מאדם עד נח and Part 2: מנח עד אברהם. Jerusalem: Magnes, Hebrew University, 1944, 1953, 1959.

Childs, Brevard. Biblical Theology in Crisis. Philadelphia: Westminster, 1970. . Introduction to the Old Testament as Scripture. $1^{\text {st }}$ American ed. Philadelphia: Fortress, 1979.

Coats, G. W. “Abraham's Sacrifice of Faith: A Form-Critical Study of Genesis 22." Interpretation 27 (1973): 389-400.

Coffin, Edna. “The Binding of Isaac in Modern Israeli Literature.” Michigan Quarterly Review (1985): 429-44.

Cohen, Abraham. Joshua-Judges: Hebrew Text \& English Translation with Introductions and Commentary. Revised Edition. Revised by A. J. Rosenberg. New York: Soncino, 1982.

Collins, Billie Jean. The Hittites and Their World. Archaeology and Biblical Studies 7. Atlanta: Society of Biblical Literature, 2007.

Collins, John J. The Bible after Babel: Historical Criticism in a Postmodern Age. Grand Rapids: W. B. Eerdmans, 2005.

Cotter, David W. Genesis. Edited by David W. Cotter, Jerome T. Walsh, and Chris Franke. Berit Olam: Studies in Hebrew Narrative \& Poetry. Collegeville, Minn.: Liturgical, 2003.

Coulot, Claude. "David à Qumrân.” Pages 315-43 in Figures de David à travers la Bible: XVIIe congrès de l'ACFEB, Lille, ler-5 septembre 1987. Edited by Louis Desrousseaux and Jacques Vermeylen. Lectio Divina 177. Paris: Cerf 1999.

Craigie, P. C. "Ugarit and the Bible: Progress and Regress in 50 Years of Literary Study." Pages 100-11 in Ugarit in Retrospect: 50 Years of Ugarit and Ugaritic. Edited by Gordon Douglas Young; Winona Lake, In.: Eisenbrauns, 1981.

Crawford, Timothy. "Reading Samson with the Dead." Perspectives in Religious Studies 35 (Fall 2008): 223-36.

Crenshaw, James L. “Journey into Oblivion.” Soundings (Summer 1975): 251-52. 
. Samson: A Secret Betrayed, a Vow Ignored. Atlanta: John Knox, 1978.

Culler, Jonathan. "Knowing or Creating? A Response to Barbara Olsen." Narrative 14 (Oct. 2006): 347-48. . "Omniscience." Narrative 12 (Jan. 2004): 22-34.

Culley, Robert C. Themes and Variations: A Study of Action in Biblical Narrative. Society of Biblical Literature Semeia Studies 23. Atlanta: Scholars Press, 1992.

Cundall, Arthur E. Judges: An Introduction and Commentary. Vol. 7 of The Tyndale Old Testament Commentary. Chicago: Intervarsity, 1968.

Curtis, Adrian H. W. Joshua. Sheffield: Sheffield Academic Press, 1994.

Damrosch, David. The Narrative Covenant: Transformations of Genre in the Growth of Biblical Literature. San Francisco: Harper \& Row, 1987.

Davies, Eryl W. The Dissenting Reader: Feminist Approaches to the Hebrew Bible. Aldershot, Hants, England; Burlington, Vt.: Ashgate, 2003.

Davies, Philip R. In Search of 'Ancient Israel'. $2^{\text {nd }}$ Edition. JSOT Supplement Series 148. Sheffield: Sheffield Academic, 1992.

De Romilly, Jacqueline. A Short History of Greek Literature. Chicago: University of Chicago Press, 1985.

Dietrich, Manfriend and Oswald Loretz. "Aqhats Ermordung als Mythos (KTU 1.18 iv 7b-41)." Pages 345-57 in Obris Ugaritus ausgewählte Beiträge von Manfried Dietrich und Oswald Loretz zu Fest- und Gedenkschriften / anlässlich des 80. Geburtstages von Oswald Loretz herausgegeben von Manfried Dietrich. Alter Orient und Altes Testament 343. Münster: Ugarit-Verlag, 2008.

Dijkstra, Meindert. "Some Reflections on the Legend of Aqhat." Ugarit Forschungen 11 (1979): 199-210.

Eissfeldt, Otto. Die Quellen des Richterbuches. Leipzig: J. C. Hinrichs, 1925. . Sanchunjaton von Berut und Ilimilku von Ugarit. Beiträge zur Religionsgeschichte des Altertums 5. Halle (Saale): N. Niemeyer, 1952.

Eslinger, Lyle M. Into the Hands of the Living God. JSOT Supplement Series 84. Bible and Literature Series 24. Sheffield: Almond, 1989. 
Emmrich, Martin. "The Symbolism of the Lion and the Bees: Another Ironic Twist in the Samson Cycle." Journal of the Evangelical Theological Society 44 no. 1 (Mar. 2001): 67-74.

Exum, Cheryl J. “Aspects of Symmetry and Balance in the Samson Saga.” Journal for the Study of the Old Testament 19 (1981): 3-29.

. “Lovis of Corinth's Blinded Samson.” Biblical Interpretation 6 (1998): 41025.

. "Promise and Fulfillment: Narrative Art in Judges 13." Journal of Biblical Literature 99 (1980) 43-59.

. Was sagt das Richterbuch den Frauen? Stuttgarter Bibelstudien 169. Stuggart: Verlag Katholisches Bibelwerk, 1997.

Exum, J. Cheryl and David J. A. Clines, eds. The New Literary Criticism and the Hebrew Bible. JSOT Supplement Series 143. Sheffield: JSOT Press, 1993.

The Fathers of the Church, A New Translation. Washington, D.C.: Catholic University of America Press, 1947-.

Feldman, Louis. “Josephus' Version of Samson." Journal for the Study of Judaism in the Persian, Hellenistic, and Roman Periods 19 (1988): 171-214.

Focant, Camille and André Wénin, ed. Analyse Narrative et Bible: Deuxiè Colloque International Du RRENAB, Louvain-La-Neuve, Avril 2004. Biblotheca Ephemeridum theologicarum Lovanesium 191. Leuven, University Press; Dudley, Mass.: Peeters, 2005.

Fokkelman, J. P. Narrative Art and Poetry in the Books of Samuel: A Full Interpretation Based on Stylistics and Structural Analysis. Vol. 2, The Crossing Fates (I Sam. 13-31 \& II Sam. 1) Assen: Van Gorcum, 1986.

Reading Biblical Narrative: An Introductory Guide. Translated by Ineke Smit. Louisville, Ky.: Westminster John Knox Press, 1999. Translation of Vertelkunst in de bijbel: een handleiding bij literair lezen. Zoetermeer, The Netherlands: Boekencentrum, 1995.

Fokkema, Douwe W. Theories of Literature: Structuralism, Marxism, Aesthetics of Reception, Semiotics. New York: St. Martins, 1978.

Foster, Benjamin R. Akkadian Literature of the Late Period. Edited by Eckhard Frahm and Michael Jursa. Guides to the Mesopotamian Textual Record 2; Münster: Ugarit-Verlag, 2007. 
Foster, Benjamin R., ed. From Distant Days: Myths, Tales, and Poetry of Ancient Mesopotamia. Bethesda, Md.: CDL Press, 1995.

Freedman, Amelia D. God as an Absent Character in Hebrew Narrative: A LiteraryTheoretical Study. Edited by Hemschand Gossai. Studies in Biblical Literature 82. New York: Peter Lang, 2005.

Fritz, Volkmar. “Abimelech und Shechem in Jdc. IX.” Vetus Testamentum 32 (1982): $129-44$.

Gafney, Wilda C. M. “A Black Feminist Approach to Biblical Studies.” Encounter 67.4 (2006): 392-403.

Galán, José. Four Journeys in Ancient Egyptian Literature. Lingua Aegyptica; Studia monographica 5. Göttingen: Seminar für Ägyptologie und Koptologie.

Gallpaz-Feller, Pnina. "'Let My Soul Die with the Philistines' (Judges 16.30)." Journal for the Study of the Old Testament 30 (2006): 315-25.

Gardiner, Alan H. Notes on the Story of Sinuhe. Librairie Honoré Champion, 1916. Photocopy, La Cross, Wi.: Brookhaven Press, 2002.

Genette, Gérard. Figures of Literary Discourse III. Translated by Alan Sheridan. European Perspectives. New York: Columbia University Press, 1982.

George, Andrew. The Epic of Gilgamesh: The Babylonian Epic Poem and Other Texts in Akkadian and Sumerian. London; New York: Penguin Books, 2003.

Gese, Hartmut. "Die ältere Simsonüberlieferung (Richter c. 14-15)." Zeitschrift für Theologie und Kirche 82 (1985): 261-80.

Goetschel, Roland. "Samson Messie chez R. Șadoq Ha-Kohen.” Pages 397-406 in Mélanges André Neher. Paris: Maisonneuve, 1975.

Good, Edwin. Preface to Irony in the Old Testament. $2^{\text {nd }}$ ed. Bible and Literature Series 3. Sheffield: Almond, 1981.

Gordon, Robert P. 1 \& 2 Samuel: A Commentary. Grand Rapids: Zondervan, 1986.

Gray, John. Joshua, Judges, Ruth. Edited by Ronald E. Clements. New Century Bible Commentary. Grand Rapids: Wm. B. Eerdmans; Basingstoke: Marshal Morgan \& Scott, 1986.

Greene, Mark. "Enigma Variations: Aspects of the Samson Story Judges 13-16." Vox evangelica 21 (1991): 51-80. 
Greenstein, Edward L. Essays on Biblical Method and Translation. Brown Judaic Studies 92. Atlanta: Scholars, 1989.

. "The Riddle of Samson." Prooftexts 1 (1981): 237-60.

. "The Role of the Reader in Ugaritic Narrative." Pages 139-151 in "A Wise and Discerning Mind: Essays in Honor of Burke O. Long. Edited by Saul M. Olyan and Robert C. Culley. Brown Judaic Studies 325. Providence, RI.: Brown Judaic Studies, 2000.

Gros Louis, Kenneth R. R. “The Book of Judges.” Pages 141-62 in Literary Interpretations of Biblical Narratives. Edited by K. Gros Louis, J. Ackerman, T. Warshaw. Nashville: Abingdon, 1974.

Grossman, David. Lion's Honey: The Myth of Samson. Translated by Stuart Schoffman. New York: Canongate, 2005.

Gumbrecht, Hans Ulrech. "Does Egyptology Need a 'Theory of Literature'?” Pages 3-18 in Ancient Egyptian Literature. Edited by Antonio Loprieno. Leiden; New York; Köln: E. J. Brill, 1996.

Gunkel, Hermann. The Legends of Genesis, The Biblical Saga and History. Whitefish, Mt.: Kessinger, 2006. Reprint of The Legends of Genesis. Translated by W. H. Carruth. New York: Schocken Books, 1964. Translation of Die Sagen der Genesis. Chicago: Open Court Publishing, 1901. . Genesis. Handbuch zum Alten Testament. Göttingen: Vandenhoeck and

Ruprecht, 1901. . "Simson," in Reden und Aufsätze. Göttingen: Vandenhoeck \& Ruprecht, 1913.

Gunn, David M. "Narrative Criticism." Pages 201-29 in To Each Its Own Meaning: An Introduction to Biblical Criticisms and Their Applications. Edited by Stephen R. Haynes and Steven L. Mackenzie. Revised and exp. ed. Louisville: Westminster John Knox, 1999.

Gunn, David M. and Danna N. Fewell. Narrative in the Hebrew Bible. Oxford Bible Series. Edited by P. R. Ackroyd and G. N. Stanton. Oxford; New York: Oxford University Press, 1993.

Gurney, Oliver R. Some Aspects of Hittite Religion. Oxford; New York: Oxford University Press for the British Academy, 1977.

Güterbock, Hans G. “A View of Hittite Literature." Journal of the American Oriental Society 84 (Apr.-Jun. 1964): 107-115. 
Haas, Volkert. Die hethitische Literatur: Texte, Stilistik, Motive. Berlin; New York: Walter de Gruyter, 2006.

Hamlin, E. John. At Risk in the Promised Land: a Commentary on the Book of Judges. Edited by Fredrick Carlson Holmgren and George A. F. Knight. International Theological Commentary. Grand Rapids, Mi.: Wm. B. Eerdmans, 1990.

Hawk, Daniel. Every Promise Fulfilled: Contesting Plots in Joshua. Edited by Danna N. Fewell and David M. Gunn. Literary Currents in Biblical Interpretation. Louisville: Westminster/John Knox, 1991.

Henry, Laurie. The Fiction Dictionary. Cincinnati, Oh.: Story, 1995.

Hoffner, Harry A. Jr. Hittite Myths. Edited by Gary M. Beckman. SBL Writings from the Ancient World 2. Atlanta: Scholars Press, 1998.

Hoppe, Leslie. Joshua, Judges. Edited by Carroll Stuhlmueller and Martin McNamara. Vol. 5 of Old Testament Message.Wilmington, De.: Michael Glazier, 1982.

Horowitz, William J. “The Ugaritic Scribe.” Ugarit Forschungen 11 (1979): 389-94.

Irvin, Dorothy. Mytharion: Comparison of Tales from the Old Testament and the Ancient Near East. Alter Orient und Altes Testament 32. Kevelaer: Butzon und Bercker; Neukirchen-Vluyn: Neukirchener Verlag, 1978.

Jacob, Benno. The First Book of the Bible: Genesis, Augmented Edition. Edited, abridged, and translated by Ernest I. Jacob and Walter Jacob. New York: Ktav, 2007. Translation of Das erste Buch der Torah, Genesis. Berlin: Schocken Verlag, 1934.

Jacobson, Howard. A Commentary on Pseudo-Philo's Liber Antiquitarium Biblicarum with Latin Text and English Translation. 2 vols. Arbeiten zur Geschichte des antiken Judentums und des Urchristentums 31. Leiden; New York: Brill, 1996.

Jans, Edgar. Abimelech und sein Königtum: diachrone und synchrone Untersuchungen zu Ri 9. Arbeiten zu Text und Sprache im Alten Testament 66. St. Ottilien: EOSVerlag, 2001.

Josephus. Flavius Josephus: Translation and Commentary. Translated by Christopher Begg et al. 10 vols. Edited by Steve Mason. Leiden; Boston: Brill, 2000-2005.

Jost, Renate. "Der Gott Der Liebe, Der Gott Der Rache Oder: Simsons 'Rachegebet."” Pages 104-13 in Von der Wurzel getragen: Christliche feministiche Exegese in Auseinandersetzung mit Antijudaismus. Edited by Luise Schottroff and MarieTheres Wacker. Leiden; New York: E. J. Brill, 1996. 
Kahl, Jochem. "Es is am anfang bis zum Ende so gekommen wie es in der Schrift gefunded worden war." Pages 385-400 in "Und Mose schriebe dieses Lied auf" Studien zum Alten Testament und zum Alten Orient: Festschrift für Oswald Loretz zur Vollendung seines 70 Lebensjahres mit Beträgen von Freunden, Schülern und Kollegen. Alter Orient und Altes Testament 250. Münster: Ugarit Verlag,1998.

Kallai, Zecharia. "The Explicit and Implicit in Biblical Narrative.” Pages 107-17 in Congress Volume: Paris 1992. Supplements to Vetus Testamentum, 61. Leiden: E. J. Brill, 1995.

Karasu, Cem. "Why Did the Hittites Have a Thousand Deities?" Pages 221-35 in Hittites Studies in Honor of Harry A. Hoffner Jr. on the Occasion of His $65^{\text {th }}$ Birthday. Edited by Gary Beckman, Richard Beal, and Gregory McMahon. Winona Lake, In.: Eisenbrauns, 2003.

Kaufmann, Yehezkel. Sefer Shoftim. Jerusalem: Kiryat-Sefer, 1962.

King, J. Robin. "The Joseph Story and Divine Politics: A Comparative Study of a Biographical Formula from the Ancient Near East." Journal of Biblical Literature 106 (1987): 577-94.

King, Philip J. and Lawrence Stager. Life in Biblical Israel. $1^{\text {st }}$ ed. Library of Ancient Israel. Louisville: Westminster John Knox Press, 2001.

Klaus, Natan. Pivot Patterns in the Former Prophets. JSOT Supplement Series 247. Sheffield: Sheffield University Press, 1999.

Klein, Jacob. The Royal Hymns of Shulgi King of Ur: Man's Quest for Immortal Fame. Transactions of the American Philosophical Society, vol. 17, pt 7. Philadelphia: American Philosophical Society, 1981. . Three Šulgi Hymns: Sumerian Royal Hymns Glorifying King Šulgi of Ur. BarIlan Studies in Near Eastern Languages and Culture. Bar-Ilan: Bar-Ilan University Press.

Klein, Lillian R. The Triumph of Irony in the Book of Judges. Bible and Literature Series 14. Sheffield: Almond, 1988.

Koenen, Klaus. “'Wem ist Weh? Wem ist Ach? . . Wer hat trübe Augen' Zur Funktion von Rätselfragen im Alten Testament.” Biblische Notizen 94 (1998): 79-86.

Korpel, Marjo C. A. A Rift in the Clouds: Ugaritic and Hebrew Descriptions of the Divine. Ugaritisch-biblische Literatur 8. Münster: Ugarit-Verlag, 1990. 
Kugel, James L. Traditions of the Bible: A Guide to the Bible As It Was at the Start of the Common Era. Cambridge, Mass.; London: Harvard University Press, 1998.

Kundert, Lukas. Die Opferung/Bindung Isaaks. 2 vols. Wissenschaftliche Monographien zum Alten und Neuen Testament 78-79. Vol. 1: Gen 22,1-19 im Alten Testament, im Frühjudentum und im Neuen Testament. Vol. 2: Gen 22, 1-19 im frühen rabbinischen Texten. Neukirchen-Vluyn: Neukirchener Verl, 1998.

Kunz, Andreas. "Sinuhe und der Starke von Retjenu—David und der Riese Goliat. Eine Skizze zum Motivegbrauch in der Literature Ägypten und Israels." Biblische Notizen 119/120 (2003): 90-100.

Lack, Rémi. "Le sacrifice d'Isaac—Analyse structural de la couche élohiste dans Gn 22." Biblica 56 (1975): 1-12.

Lang, Bernhard. "Von der Kriegerischen zur nativistischen Kultur. Das alte Israel im Lichte de Kulturanthropologie." Evangelische Theologie 68 (2008): 430-43.

Lawlor, John I. "Theology and Art in the Narrative of the Ammonite War (2 Samuel 1012)." Grace Theological Journal 3.2 (1982): 193-205.

Lee, Dal. The Narrative Asides in the Book of Revelation. Lanham, Md.: University Press of America, 2002.

Lenzi, Alan. Secrecy and the Gods: Secret Knowledge in Ancient Mesopotamia and Biblical Israel. State Archives of Assyria Studies XIX. Helsinki: The NeoAssyrian Text Corpus Project, 2008.

Licht, Jacob. Storytelling in the Bible. Jerusalem: Magness, 1978.

Lichtheim, Miriam. Ancient Egyptian Literature. 3 volumes. Berkley and Los Angeles: University of California Press, 1973-1980.

Lilley, J. P. U. "A Literary Appreciation of the Book of Judges." Tyndale Bulletin 18 (1967): 94-102.

Loprieno, Antonio. "Defining Egyptian Literature." Pages 39-58 in Ancient Egyptian Literature. Edited by Antonio Loprieno. Leiden; New York; Köln: E. J. Brill, 1996.

Lotman, Jurij. The Structure of the Artistic Text. Translated from the Russian by Gail Lenhoff and Ronald Vroon. Michigan Slavic Contributions 7. Ann Arbor: University of Michigan, 1997. 
Louden, Bruce. "The Divine Economy." Pages 91-104 in A Companion to Ancient Epic. Edited by John Miles Foley. Blackwell Companions to the Ancient World; Literature and Culture. Malden, Mass.: Oxford: Blackwell Publishing, 2005.

Machinist, Peter. "On Self-Consciousness in Mesopotamia." Pages 183-202 in The Origins and Diversity of Axial Age Civilizations. Edited by S. N. Eisenstadt. SUNY Series in Near Eastern Studies. Albany: State University of New York Press, 1986.

. "Rest and Violence in the Poem of Erra." Journal of the American Oriental Society 103 (Jan.-Mar. 1983): 221-26.

Maimonides, Moses. Crisis and Leadership: Epistles of Maimonides. Translated by Abraham Halking. Discussions by David Hartman. Philadelphia: Jewish Publication Society, 1985.

Malbon, Elizabeth Struthers. "Narrative Criticism: How Does the Story Mean?" Pages 29-58 in Mark and Method: New Approaches in Biblical Studies. Edited by Janice C. Anderson and Stephen D. Moore. Minneapolis: Fortress, 1992. Repr., Minneapolis: Fortress, 2008.

Manns, Frédéric, ed. The Sacrifice of Isaac in Three Monotheistic Religions: Proceedings of a Symposium on the Interpretation of the Scriptures held in Jerusalem, March 16-17, 1995. Jerusalem: Franciscan Printing Press, 1995.

Marchese, Angelo. L'officina del racconto. Semiotica della narratività. Milano: Mondadori, 1983.

Margalit, Baruch. "K-R-T Studies.” Ugarit Forschungen 27 [1995]: 215-315. . The Ugaritic Poem of Aqht. Beihefte zur Zeitschrift für die alttestamentliche Wissenschaft 182. Berlin; New York: Walter de Gruyter, 1989.

Marguerat, Daniel. "Entrer dans le monde du récit." Pages 9-37 in Quand la Bible se raconte. Edited by Daniel Marguerat. Lire la Bible 134. Paris: Cerf, 2003.

Martin, James D. The Book of Judges. Edited by P. R. Ackroyd, A. R. C. Leaney, and J. W. Packer. The Cambridge Bible Commentary. London: Cambridge University Press, 1975.

Martínez, Florentino García. "The Sacrifice of Isaac in 4Q225. Pages 44-57 in The Sacrifice of Isaac: The Aqedah (Genesis 22) and its Interpretations. Edited by Noort and Eibert Tigchelaar. Themes in Biblical Narrative, Jewish and Christian Traditions. Leiden; Boston; Köln: Brill, 2002. 
Mastrocinque, Attilo. "The Cilian God Sandras and the Greek Chimaera: Features of Near Eastern and Greek Mythology Concerning the Plague." Journal of Ancient Near Eastern Religions 7 no. 2 (2007): 197-217.

Matthews, Victor H. Judges \& Ruth. Edited by Ben Witherington III and Bill T. Arnold. New Cambridge Bible Commentary. Cambridge: Cambridge University Press, 2004.

Mazoyer, Michel. Télepinu, Le Dieu au marécage: Essai sur les mythes fondateurs du royaume Hittite. Collection Kubaba, Série Antiquité 2. Harmattan; Paris: Association Kubaba, 2003.

McAlpine, Thomas H. Sleep, Divine, and Human in the Old Testament. JSOT Supplement Series 38. Edited by David J. A. Clines and Philip R. Davies. Sheffield: Sheffield Academic Press, 1987.

McCann, J. Clinton. Judges. Interpretation: A Bible Commentary for Teaching and Preaching. Louisville: John Knox, 1989.

McCarter, P. Kyle Jr. “The Apology of David.” Journal of Biblical Literature 99 (Dec. 1980): 489-504.

. II Samuel: A New Translation with Introduction, Notes and Commentary. The Anchor Bible 9. Garden City: Doubleday, 1984.

McConville, J. Gordon and Stephen N. Williams. Joshua. Edited by J. Gordon McConville and Craig Bartholomew. The Two Horizons Old Testament Commentary. Grand Rapids, Mi.; Cambridge, U.K.: William B. Eerdmans, 2010.

McKenzie, Steven L. King David: A Biography. Oxford; New York: Oxford University Press, 2000.

McMahon, Gregory. "Hittite Texts and Literature." Anchor Bible Dictionary 3: 228-31.

Melchert, H. Craig. "The Acts of Hattušili I.” Journal of Near Eastern Studies 37 (Jan. 1978): 1-22.

Midrash Numbers Rabbah. Edited and translated by H. Freedman and Maurice Simon. Translated by J. J. Slotki. London: Soncino, 1983.

Millard, Matthias. "Samson und das Ende des Richterbuches: Ein Beispiel Einer Kanonexegese Zwischen Kompositions Und Wirkungsgeschtlicher Auslegung." Pages 227-34 in The Biblical Canons. Edited by J. M. Auwers and H. J. De Jonge. Leuven: Leuven University Press, 2003. 
Milstein, Sara J. Reworking Ancient Texts: Revision through Introduction in Biblical and Mesopotamian Literature. Ph.D. dissertation. New York University. Retrieved July 16, 2011, from Dissertations \& Theses: A\&I. Publication No. AAT 3428044.

Mobley, Gregory. Samson and the Liminal Hero in the Ancient Near East. Library of Hebrew Bible/Old Testament Studies. New York: T \& T Clark, 2006.

Moberly, R. W. L. "Does God Lie to His Prophets? The Story of Micaiah ben Imlah as a Text Case." Harvard Theological Review 96.1 (2003) 1-23.

Mowinckel, Sigmund. "Hat es ein israelitisches Nationalepos gegeben?" Zeitschrift für die alttestamentlich Wissenschaft 53 (1935): 130-52.

Moore, Stephen D. Literary Criticism and the Gospels: The Theoretical Challenge. New Haven: Yale University Press, 1989.

Mullen, E. Theodore Jr. The Divine Council in Canaanite and Early Hebrew Literature. Edited by Frank M. Cross. Harvard Semitic Monographs 24. Chico, Ca.: Scholars Press, 1980.

Müller, Gerfrid G. W. "Wer Spricht? Betrachtungen zu 'Isum and Erra.'” Pages 349-60 in Vom Alten Orient zum Alten Testament: Festschrift für Wolfram Freiherrn von Soden zum 85. Geburtstag am 19. Juni 1993. Edited by Dietrich Manfried and Oswald Loretz; Alter Orient und Altes Testament 240. Kevelaer: Verlag Butzon \& Bercker; Neukirchen-Vluyn: Neukirchener Verlag, 1995.

“Narrative Research on the Hebrew Bible." Semeia 46 (1989): 3-179.

Nelson, Richard D. Joshua: A Commentary. Edited by James L. Mays, Carol A. Newsom, and David L. Petersen. The Old Testament Library. Louisville: Westminster John Knox, 1997.

Neusner, Jacob, trans. Genesis Rabbah: The Judaic Commentary to the Book of Genesis: A New American Translation. 3 volumes. Brown Judaic Studies 104-06. Atlanta: Scholars Press, 1985.

Neusner, Jacob, and W. S. Green, eds. Dictionary of Judaism in the Biblical Period. Peabody: Hendrickson, 1999.

Niditch, Susan. "The Challenge of Israelite Epic." Pages 277-87 in A Companion to Ancient Epic. Edited by James M. Foley. Blackwell Companions to the Ancient World. Malden, Mass.; Oxford: Blackwell, 2005. 
Noll, K. L. The Faces of David. JSOT Supplement Series 242. Sheffield: Sheffield Academic Press, 1997.

Norton, David. A History of the Bible as Literature. Revised ed. Cambridge, U.K.; New York: Cambridge University Press, 2000.

Noth, Martin. The Deuteronomistic History. $2^{\text {nd }}$ edition. JSOT Supplement Series 15. Sheffield: JSOT Press, 1991. Translation of Überlieferungsgeschicthliche Studien I: die sammelnden und bearbeiten Geschichtswerke im Alten Testament. Halle [Saale] M. Niemeyer, 1943.

Olson, Barbara K. "“Who Thinks This Book?' Or Why the Author/God Analogy Merits Our Continued Attention." Narrative 14 (Oct. 2006): 339-46.

Parker, Simon B. The Pre-Biblical Narrative Tradition. Society of Biblical Literature Resources for Biblical Study 24. Edited by W. Lee Humphreys. Atlanta: Scholars Press, 1989.

Parker, Simon B., ed. Ugaritic Narrative Poetry. SBL Writings from the Ancient World 9. Atlanta: Scholars Press, 1997.

Parkinson, Richard B. "Individual and Society in Middle Kingdom Literature." Pages 137-55 in Ancient Egyptian Literature. Edited by Antonio Loprieno. Leiden; New York; Köln: E. J. Brill, 1996.

. "Types of Literature in the Middle Kingdom." Pages 297-312 in Ancient Egyptian Literature. Edited by Antonio Loprieno. Leiden; New York; Köln: E. J. Brill, 1996.

Pascal, Roy. The Dual Voice: Free Indirect Speech and its Functioning in the NineteenthCentury European Novel. Manchester, Eng.: Manchester University Press; Totowa, NJ.: Rowan and Littlefield, 1977.

Perry, Menakhem and Meir Sternberg. "The King through Ironic Eyes: Biblical Narrative and the Literary Reading Process" (in Hebrew). Ha-sifrut 1:2 (Summer, 1968): 263-292. For the English reprint see, Poetics Today 7:2 (1986): 275-322.

Pettrazoni, R. “On the Attributes of God.” Numen 2 (Jan.-Feb. 1955): 1-27.

Pieper, Max. Die Ägyptische Literatur. Handbuch der Literaturwissenschaft. WildparkPotsdam: Akademische verlagsgesellschaft Athenaion, 1928, 39.

Polak, Frank. "Some Aspects of Literary Design in the Ancient Near Eastern Epic." Pages 135-46 in kinnattū ša dārāti: Raphael Kutscher Memorial Volume. Edited by A. F. Rainey. Tel Aviv: Tel Aviv Institute of Archaeology, 1993. 
Polzin, Robert. Samuel and the Deuteronomist: I Samuel. A Literary Study of the Deuteronomistic History, part 2. $1^{\text {st }}$ ed. San Francisco: Harper \& Row, 1989

Polzin Robert M. and Eugene Rothman, eds. The Biblical Mosaic: Changing Perspectives. Semeia Studies. Philadelphia, Pa.: Fortress; Chico, Ca.: Scholars, 1982.

Powell, Mark A. "Narrative Criticism." Pages 169-72 in Methods of Biblical Interpretation. Excerpted from the Dictionary of Biblical Interpretation. Edited by John H. Hayes. Nashville: Abingdon, 1999.

Pressler, Carolyn. Joshua, Judges, and Ruth. Edited by P. D. Miller and D. L. Bartlett. Westminster Bible Companion. Louisville: Westminster John Knox, 2000.

Prooftexts 27 (Spring 2007): 191-370.

Pyper, Hugh S. David as Reader: 2 Samuel 12:1-15 and the Poetics of Fatherhood. Biblical Interpretation 23. Leiden; New York: E. J. Brill, 1996.

Rad, Gerhard von. Genesis: A Commentary. Translated by John H. Marks. The Old Testament Library. Philadelphia: Westminster, 1972. Translation of Das erste Buch Mose. Ninth ed. Göttingen Vandenhoeck \& Ruprecht, 1972.

. Das Opfer des Abraham mit Texten von Luther, Kierkegaard, Kolakowski und Bildern von Rembrandt. Kaiser Tractate 6. München: C. Kaiser, 1971.

Rainey, Anson F. "The Scribe at Ugarit His Position and Influence." Proceedings of the Israel Academy of Sciences and Humanities 3 no. 4 (1968): 126-46.

Rendsburg, Gary A. "Literary Devices in the Story of the Shipwrecked Sailor." Journal of the American Oriental Society 120 (Jan.-Mar. 2000): 13-23.

Rhoads, David M. "Narrative Criticism and the Gospel of Mark." Journal of the American Academy of Religion 50 (1982): 411-34.

Rhoads, David M., and Donald Michie. Mark as Story: An Introduction to the Narrative of a Gospel. Philadelphia: Fortress, 1982. Repr., Minneapolis: Fortress, 1999.

Richter, Wolfgang. Die Bearbeitung des "Retterbuches" in der deuteronomischen Epoch. Bonn: Peter Hanstein, 1964. 
Exegese als Literaturwissenschaft: Entwurf einer alttestamentlichen

Literaturtheorie und Methodologie. Göttingen: Vandenhoeck and Ruprecht, 1971.

. Traditionsgeschichtliche Untersuchunge zum Rictherbuch. Bonn: Peter

Hanstein, 1963.

Rimmon-Kenan, Shlomith. Narrative Fiction: Contemporary Poetics. 2nd ed. London; New York: Routledge, 2002.

Roncace, Mark. "Another Portrait of Josephus's Portrait of Samson." Journal for the Study of Judaism in the Persian, Hellenistic, and Roman Periods 35 (2004): 185207.

Rosenblatt, Jason P. and Joseph C. Sitterson, Jr., eds. "Not in Heaven": Coherence and Complexity in Biblical Narrative. Indiana Studies in Biblical Literature. Bloomington: Indiana University Press, 1991.

Royle, Nicholas. The Uncanny. New York: Routledge, 2003.

Ruiten, Jacques van. "Abraham, Job, and the Book of Jubilees: The Intertextual Relationship of Genesis 22:1-19, Job 1:1-2:12 and Jubilees 17:15-18:19." Pages 58-85 in The Sacrifice of Isaac: The Aqedah (Genesis 22) and its Interpretations. Edited by Ed Noort and Eibert Tigchelaar. Leiden; Boston; Köln: Brill, 2002.

Ryan, Roger. Judges. Edited by John Jarick. Readings: A New Biblical Commentary. Sheffield: Sheffield Phoenix, 2007.

Sarna, Nahum M. "The Anticipatory Use of Information as a Literary Feature of the Genesis Narratives." Pages 211-20 in Studies in Biblical Interpretation. Philadelphia: The Jewish Publication Society, 2000.

Sasson, Jack M. "Comparative Observations on the Near Eastern Epic Traditions." Pages 215-32 in A Companion to Ancient Epic. Edited by John Miles Foley. Blackwell Companions to the Ancient World, Literature and Culture. Malden, Mass.:

Oxford: Blackwell Publishing, 2005.

Judges. The Anchor Yale Bible Commentary, forthcoming.

. "Literary Criticism, Folklore Scholarship, and Ugaritic Literature." Pages 8198 in Ugarit in Retrospect: Fifty Years of Ugarit and Ugaritic. Edited by Gordon Douglas Young. Winona Lake, In.: Eisenbrauns, 1981. 
. "Oracle Inquiries in Judges." Pages 149-68 in Birkat Shalom: Studies in the Bible, Ancient Near Eastern Literature, and Postbiblical Judaism Presented to Shalom M. Paul on the Occasion of His Seventieth Birthday. Edited by Chaim Cohen et al. Winona Lake: Eisenbrauns, 2008.

. "The Servant's Tale: How Rebekah Found a Spouse.” Journal of Near Eastern Studies 65 (2006): 241-65.

Sasson, Jack M., ed. Civilizations of the Ancient Near East. 4 volumes in 2. Peabody, Mass.: Hendrickson Publishers, 2000.

Savran, George "The Character as Narrator in Biblical Narrative." Prooftexts (Jan. 1985): 11-17.

. A Manual of Hermeneutics. With José María Bravo. Translated by Liliana M. Rosa. Further editing by Brook W. R. Pearson. Biblical Seminar 54. Sheffield: Sheffield Academic, 1998.

Schneider, Tammi. Judges. Collegeville, Minn.: The Liturgical Press, 2000.

Scherman, Rabbi Nosson. The Early Prophets with a Commentary Anthologized from the Rabbinic Writings. Edited by Rabbi Meir Zlotowitz and Rabbi Feivel Wahl. 1st ed. The Art Scroll Series. The Rubin Edition. Brooklyn: Mesorah Publications, 2000 .

Seybold, Klaus. "Erzählen vom Erzählen. Beobachtungen zu einer biblischen Erzähltheorie." Theologische Zeitschrift 61 (2005): 14-26.

. Poetik der erzählenden Literatur im Alten Testament. Poetlogische Studien zum Alten Testament 2, Stuttgart: Kohlhammer, 2006.

Sheely, Steven M. Narrative Asides in Luke-Acts. JSNT Supplement Series 72. Sheffield: JSOT Press, 1992.

Sheppard, Gerald T. "Canonical Criticism." Pages 861-66 in vol. 1 of The Anchor Bible Dictionary. Edited by D.N.F. Freedman. 6 vols. New York, 1992.

Singer, Itamar. Hittite Prayers. SBL Writings from the Ancient World 11. Edited by Harry A. Hoffner, Jr. Atlanta: Society of Biblical Literature, 2002.

Ska, Jean Louis. "De quelques ellipses dans les récits bibliques.” Biblica 76 (1995): 63-71. . "Our Fathers Have Told Us": Introduction to the Analysis of Biblical Narratives. Subsidia Biblica 13. Roma: Editrice Pontificio Istituto Biblico, 1990. 
Ska, Jean Louis, Jean-Pierre Sonnet, and André Wénin. "L'Analyse narrative des récits de l'Ancien Testament.” Cahiers Évangile 107 (1999): 1-66.

Smelik, Willem F. The Targum of Judges. Oudtestamentische Studiën 36. Leiden: E. J. Brill, 1995.

Speiser, E. A. Genesis, Anchor Bible. Garden City: Doubleday, 1964.

. "An Intrusive Hurro-Hittite Myth." Journal of the American Oriental Society 62 (Jun. 1942): 98-102.

Sperling, S. David, ed., Students of the Covenant: A History of Jewish Biblical Scholarship in North America. Confessional Perspectives Series. Society of Biblical Literature. Scholars Press, Atlanta, 1992.

Sternberg, Meir. "Omniscience in Narrative Construction: Old Challenges and New" Poetics Today 28:4 (Winter 2007): 683-794.

. The Poetics of Biblical Narrative: Ideological Literature and the

Drama of Reading. The Indiana Literary Biblical Series. Bloomington: Indiana University Press, 1987. Ebook on-line. Available from http://www.netlibrary.com/Details.aspx.

Tannehill, Robert C. The Narrative Unity of Luke-Acts: A Literary Interpretation. Foundations and Facets. Philadelphia: Fortress, 1986.

Tertel, Hans Jürgen. Text and Transmission: An Empirical Model for the Literary Development of Old Testament Narratives. BZAW 221. Berlin; New York: Walter de Gruyter, 1994.

Tidiman, Brian. Le Livre des juges. Vaux-sur-Seine: Edifac, 2004.

Tolmie, François. Narratology and Biblical Narratives: A Practical Guide. San Francisco: International Scholars, 1999.

Triomphe, Robert. "Le Lion et le Miel." Revue d'historie et de philosophie religieuses 62 (1982): 113-40.

Ünal, Ahmet. “The Power of Narrative in Hittite Literature.” Biblical Archaeologist 52 (Je-S 1989): 130-43.

. "Word Play in Hittite Literature." Pages 377-88 in Hittites Studies in Honor of Harry A. Hoffner Jr. on the Occasion of His $65^{\text {th }}$ Birthday. Edited by Gary Beckman, Richard Beal, and Gregory McMahon. Winona Lake, In.: Eisenbrauns, 2003. 
Valler, Shulamit. 'King David and 'His' Women: Biblical Stories and Talmudic Discussions." Pages 129-41 in The Feminist Companion to the Bible. Edited by Athalya Brenner. Sheffield: Sheffield Academic Press, 1994.

Vanstiphout, H. L. J. "Reflections on the Dream of Lugalbanda (A typological and interpretive analysis of LH 322-365)." Pages 397-412 in Intellectual Life of the Ancient Near East: Papers Presented at the $43^{\text {rd }}$ Rencontre assyriologique international Prague, July 1-5, 1996 (ed. Jiř́i Prosecký; Prague: Oriental Institute, 1998.

Vogelzang, Marianna E. "Patterns Introducing Direct Speech in Akkadian Literary Texts.” Journal of Cuneiform Studies 42 (Spr. 1990): 50-70.

Walsh, Jerome T. Style \& Structure in Biblical Hebrew Narrative. Collegeville, Minn.: Liturgical Press, 2001.

Watson, Wilfred G. E. “Abrupt Speech in Ugaritic Narrative Verse.” Ugarit Forschungen 22 (1990): 415-20.

Webb, Barry G. The Book of Judges: An Integrated Reading. JSOT Supplement Series 46. Sheffield: JSOT Press, 1987.

Weiss, Meir. "Einiges über die Bauformen des Erzählens in der Bibel.” Vetus Testamentum 13 (1963): 456-75.

Weitzman, Steven. "Before and After The Art of Biblical Narrative." Prooftexts 27 (2007): 191-210. . “The Samson Story as Border Fiction.” Biblical Interpretation 10 (2002): 15874.

Wellek, René. Concepts of Criticism. Edited by Stephen G. Nichols, Jr. New Haven: Yale University Press, 1963.

Wénin, André Isaac ou l'épreuve d'Abraham: Approche narrative de Genèse 22. Bruxelles: Éditions Lessius, 1999.

Westermann, Claus. Erzählungen in den Schriften des Alten Testaments. Arbeiten zur Theologie 86. Stuggart: Calwer, 1998. . Genesis: A Practical Commentary. Translated by David E. Green. Text and Interpretation. Grand Rapids: W. B. Eerdmans, 1987.

Wharton, James A. "The Secret of Yahweh: Story and Affirmation in Judges 13-16." Interpretation 27 (1973): 48-66. 
Wiesel, Elie. Messengers of God: Biblical Portraits and Legends. $1^{\text {st }}$ Touchstone ed. New York: Simon \& Schuster, 1994. Reprint of Messengers of God. Translated by Marion Wiesel. New York: Simon \& Schuster, 1976. Translation of Célébration biblique: portraits et légendes. Paris: Éditions du Seuil, 1975.

Wilcock, Michael. The Message of Judges. Edited by J. A. Motyer. The Bible Speaks Today. Downers Grove, Il.: InterVarsity,1992.

Willi-Plein, Ina. "Die Versuch steht am Schluss. Inhalt und Ziel der Versuchung Abrahams nach der Erzählung in Gen 22." Theologische Zeitschrift 48 (1992): $100-08$.

Woudstra, Martin H. The Book of Joshua. New International Commentary on the Old Testament. Grand Rapids, Mi.: Eerdmans, 1981.

Wright, G. Ernest. "The Literary and Historical Problem of Joshua 10 and Judges 1." Journal of Near Eastern Studies vol. 5, no. 2 (Apr. 1946): 105-14.

Wyatt, Nick. Religious Texts from Ugarit: The Words of Illimilku and his Colleagues. Sheffield: Sheffield Academic Press, 1998.

.Word of Tree and Whisper of Stone, and other papers on Ugaritian thought. Gorgias Ugaritic Studies 1. Piscataway, NJ.: Gorgian Press, 2007.

Yee, Gale A. “'Fraught with Background' Literary Ambiguity in II Samuel 11.” Interpretation 42 (1988): 240-58.

Younger, K. Lawson, Jr. Judges and Ruth. The NIV Application Commentary. Grand Rapids, Mi.: Zondervan, 2002.

Zakovitch, Yair. "David's Last and Early Days." Pages 37-52 in From Bible to Midrash: Portrayals and Interpretive Practices. Edited by Hanne Trautner-Kromann. Scandinavian Jewish Studies 10. Lund: Arcus, 2005. . Haye Shimshon. Jerusalem: Magness, 1982. 